Portland State University

PDXScholar

9-1997

\title{
Geologic Evidence of Historic and Prehistoric Tsunami Inundation at Seaside, Oregon
}

\author{
Brooke K. Fiedorowicz \\ Portland State University
}

Follow this and additional works at: https://pdxscholar.library.pdx.edu/open_access_etds

Part of the Geology Commons

Let us know how access to this document benefits you.

\section{Recommended Citation}

Fiedorowicz, Brooke K., "Geologic Evidence of Historic and Prehistoric Tsunami Inundation at Seaside, Oregon" (1997). Dissertations and Theses. Paper 5737.

https://doi.org/10.15760/etd.7608

This Thesis is brought to you for free and open access. It has been accepted for inclusion in Dissertations and Theses by an authorized administrator of PDXScholar. Please contact us if we can make this document more accessible: pdxscholar@pdx.edu. 


\section{THESIS APPROVAL}

The abstract and thesis of Brooke K. Fiedorowicz for the Master of Science in

Geology presented June 5, 1997, and accepted by the thesis committee and the department.

COMMITTEE APPROVALS:

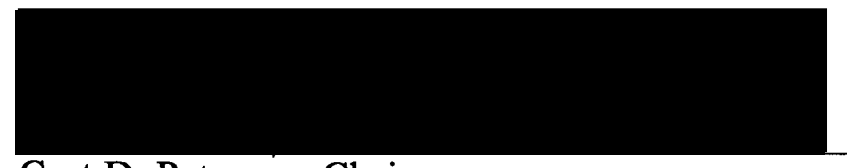

Curt D. Peterson, Chair

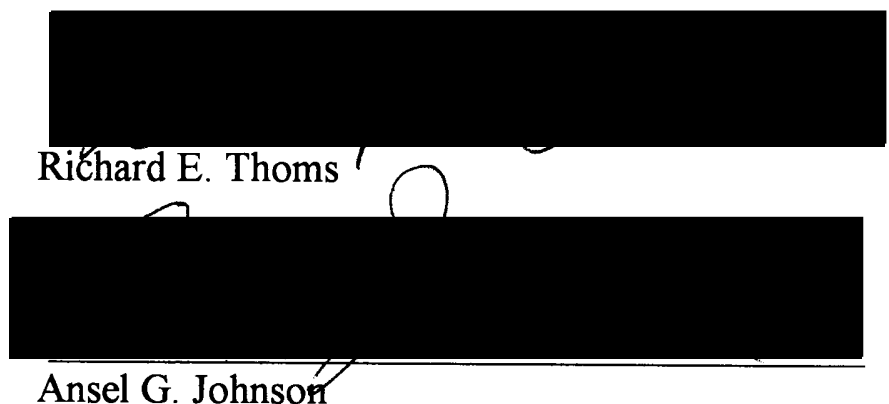

Ansel G. Johnson

Daniel M. Johńson

Representative of the Office of Graduate Studies

DEPARTMENTAL APPROVAL:

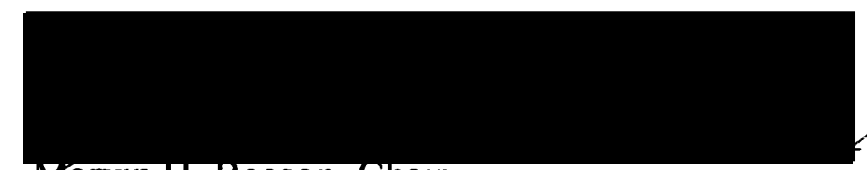

Marvin H. Beeson, Chair

Department of Geology

ACCEPTED FOR PORTLAND STATE UNIVERSITY BY THE LIBRARY

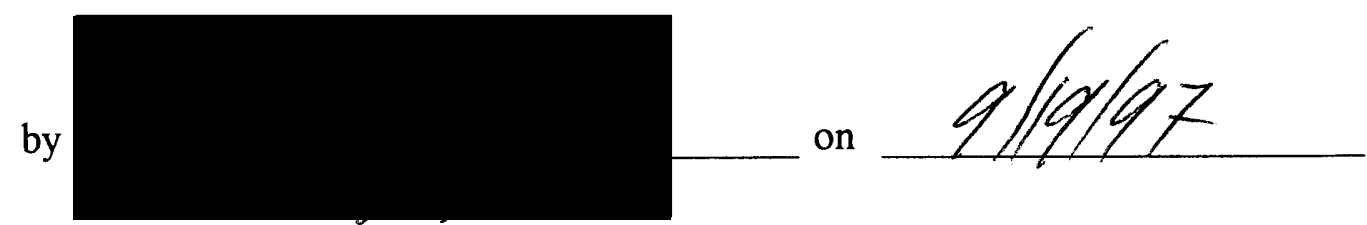




\begin{abstract}
An abstract of the thesis of Brooke K. Fiedorowicz for the Master of Science in Geology presented June 5, 1997.

Title: Geologic Evidence of Historic and Prehistoric Tsunami Inundation at Seaside, Oregon
\end{abstract}

Over the past decade, research conducted along the Cascadia subduction zone coast established evidence for coseismic subsidence, liquefaction, and nearfield tsunami deposition. Seaside is a low lying northern Oregon coastal city potentially at risk for nearfield tsunami inundation from a Cascadia earthquake. The 1964 Alaskan farfield tsunami impacted Seaside, and deposits from that event serve as a model for interpreting prehistoric tsunami deposits in the Seaside area.

A reconnaissance subsurface study of potential tsunami inundation sites was performed by trenching and gouge coring in the coastal wetlands along the Necanicum River, Neacoxie Creek, drainage to the east of Neacoxie Creek, Stanley Lake, and Neawanna Creek. A total of 278 core sites were logged for shallow lithologic stratigraphy and contact relations.

To establish tsunami depositional trends from the 1964 farfield event, 71 observation sites, 62 core logs, two grids, and eight trenches were evaluated. Wave amplification occurred in the Necanicum River/estuary mouth and north of 12th Avenue, south of the G Street bridge crossing Neacoxie Creek, and south of the HWY. 
101 bridge crossing Neawanna Creek. These areas contain anomalously thick sand deposits compared to the deposits along the Necanicum River and Neawanna Creek where the wave attenuated, depositing a sand layer thinning up stream.

Neawanna Creek wetlands contain most of the preserved $1700 \mathrm{AD}$ earthquake subsidence horizons and sand layers. Within the Seaside wetlands, 90 core sites contain the $1700 \mathrm{AD}$ subsidence horizon. No subsided peaty horizons were observed west of Neawanna Creek. At the Mill Creek/Stanley Lake area, the $1700 \mathrm{AD}$ tsunami deposition is minimal to non-existent. In the southernmost Neawanna wetlands, 1700 $\mathrm{AD}$ tsunami deposits are restricted to a narrow zone southeast of the Mill Ponds and north of S Avenue bridge.

Overland inundation of the $1700 \mathrm{AD}$ tsunami, interpreted from core records, did not reach the central Neawanna wetlands $(<1.5 \mathrm{~km}$ east of the present coastline) and crossed a narrow cobble ridge entering the Neawanna wetlands from a southern Necanicum channel. 
GEOLOGIC EVIDENCE OF HISTORIC AND PREHISTORIC TSUNAMI INUNDATION AT SEASIDE, OREGON.

by

BROOKE K. FIEDOROWICZ

A thesis submitted in partial fulfillment of the requirements for the degree of

\author{
MASTER OF SCIENCE \\ in \\ GEOLOGY
}

Portland State University 


\section{Acknowledgments}

The road to a completed master's thesis is a long, arduous process with many people involved. Oregon Department of Geology and Mineral Industries (DOGAMI) intergovernmental agreement contract \#4110002 administered by George Priest and the Office of Naval Research, U. S. government prime contract \#N600014-96-1-0893 administered by the Oregon Graduate Institute supported the research for this thesis. However, without the reasoning, assistance, and push from my primary advisor, Curt Peterson, the actual thesis process would still be continuing. He also took the time to understand a midwesterner and introduce her to the way of the waves.

The many people of Seaside who contributed observation sites and allowed access to the wetlands are greatly appreciated. Dr. Charles Rosenfeld and the many people at Camp Rilea are thanked for providing a roof over my head and an alarm clock in the morning. A special thanks goes to Tom Horning for contributing his observation sites for the 1964 tsunami, including a runup map, and for numerous discussions. My Seaside High School field helper, Jeff Siler, was of tremendous assistance even while making me realize that not everyone understands or enjoys field work. The Stand (Ave. U) is also thanked for serving excellent Mexican food so I could have the strength and energy to continue coring.

Additional thanks go to the people in Portland. The remainder of my committee provided insight and gave that additional push at the end. Bob Pinotti and Mark Scott are especially thanked for their time, patience, and knowledge of Arc Info and Arc View. Chip Barnett provided his time and skilled diatom identifying eyes. Gene 
Pierson is thanked for his patience in dealing with all grant paperwork. Also, Ed Myers, III is appreciated for discussions involving modeling processes and tsunami wave characteristics.

In addition, Harry Jol and Sandy Vandenburgh (the Canadians) are greatly thanked for taking time to run three additional GPR profiles in Seaside.

Finally, I would like to thank Michael Winkler for encouraging me to continue my education, for motivating and supporting me through the stressful times, and for making me realize that I should pursue what I enjoy. 


\section{Table of Contents}

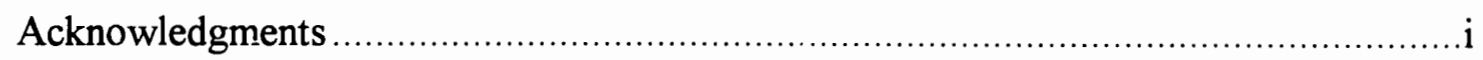

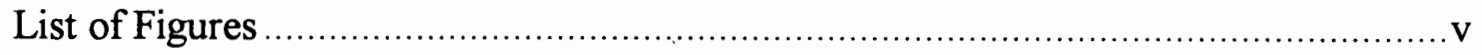

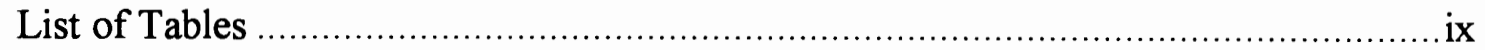

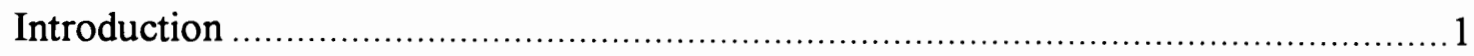

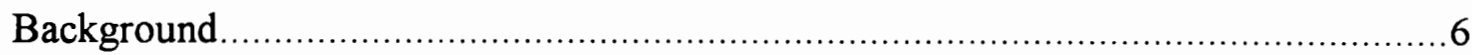

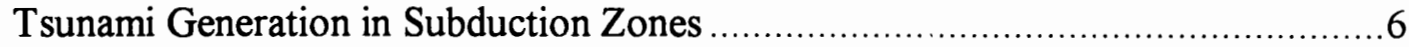

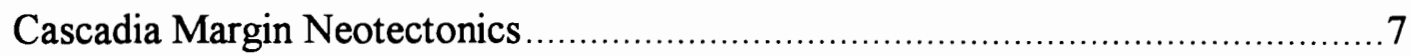

Historic Records of Subduction Zone Generated Tsunami................................8

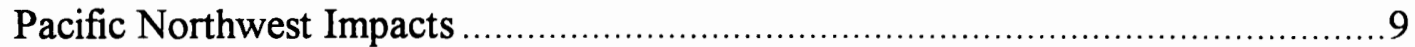

1964 Alaskan Tsunami Impacts in Pacific Northwestern Region..........................11

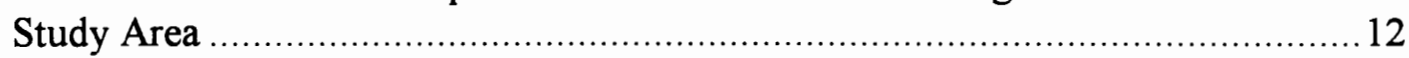

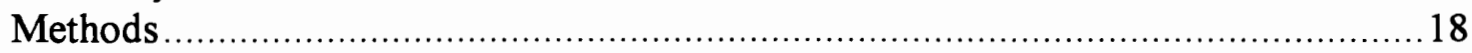

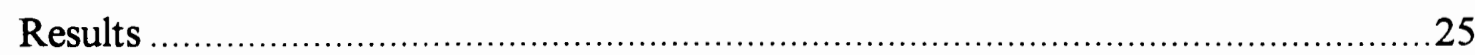

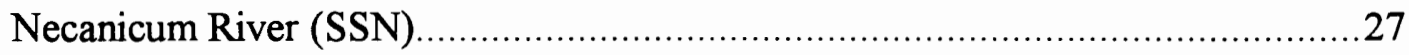

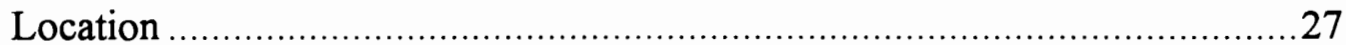

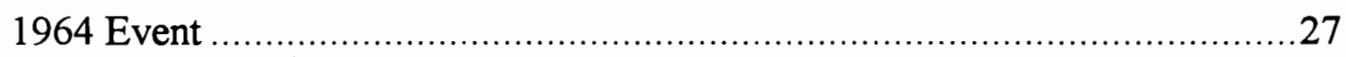

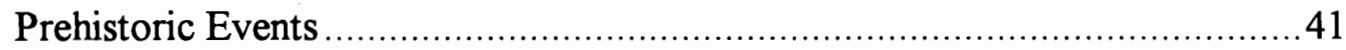

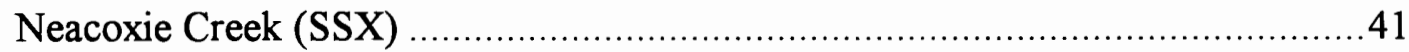

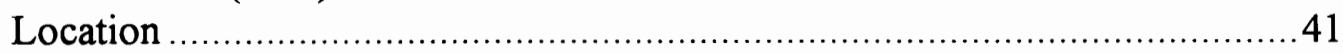

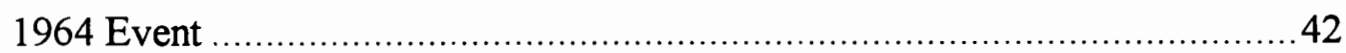

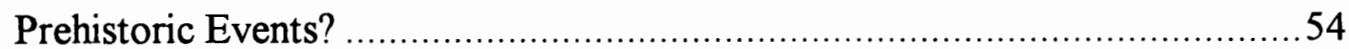

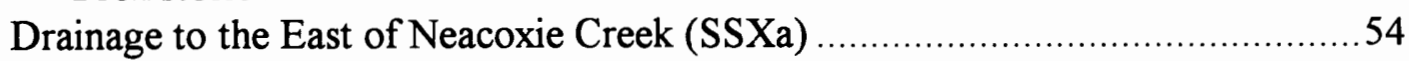

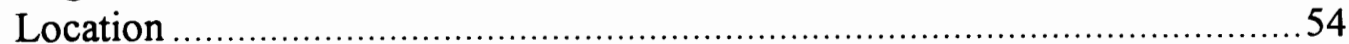

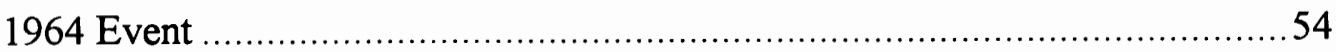

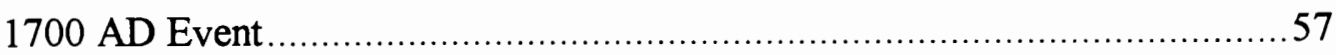

Stanley Lake (SSS)

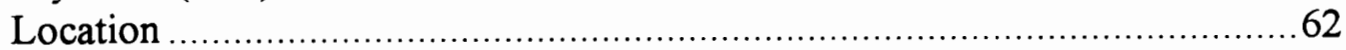

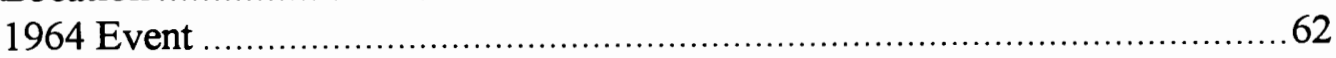

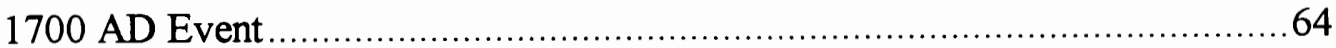

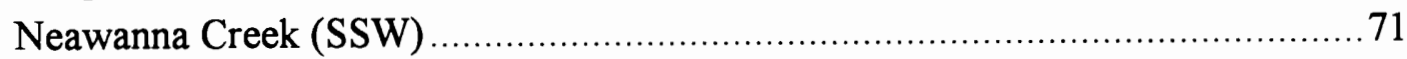

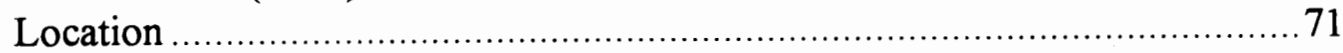

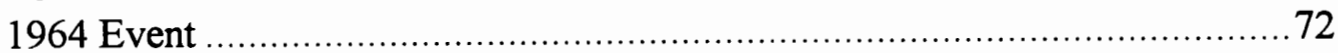

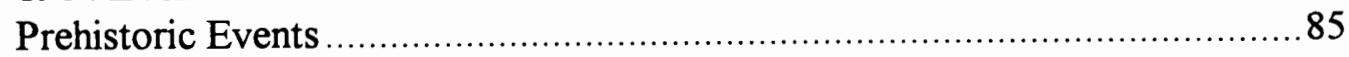

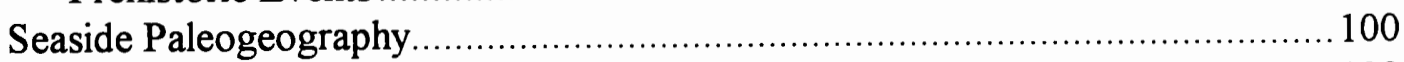

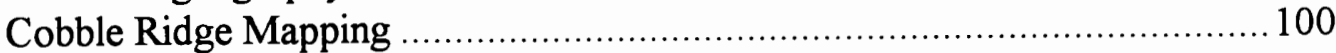

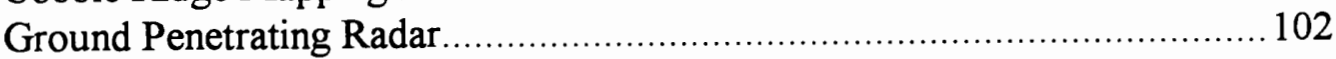

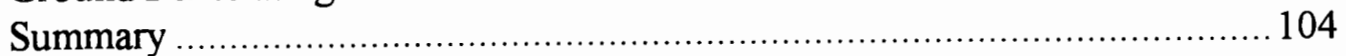

Discussion

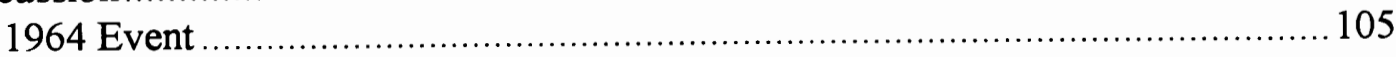

Historic 1964 Tsunami Surges in Seaside Tidal Creeks.............................. 106 
Historic 1964 Tsunami Deposits in Seaside Tidal Creek Wetlands

Comparisons of the 1964 Tsunami Impacts in Seaside with other Pacific

Northwest Localities

Correspondence between 1964 Tsunami Runup and Tsunami Depositional

Record

1964 Runup

Paleogeography of the Seaside Wetlands .............................................. 118

Paleosubsidence Horizons in Seaside ..................................................... 122

1700 Subsidence Horizon .............................................................. 124

Older Subsidence Horizons ........................................................... 126

Discrimination of Potential Paleotsunami Deposits from Liquefied Intruded

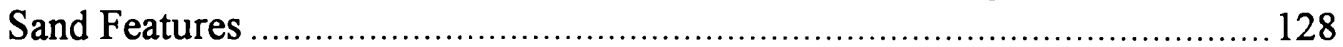

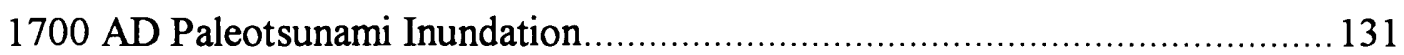

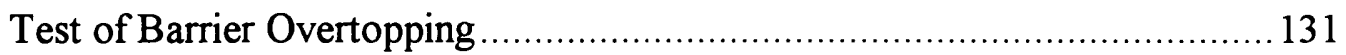

Minimum Overland Inundation..................................................... 135

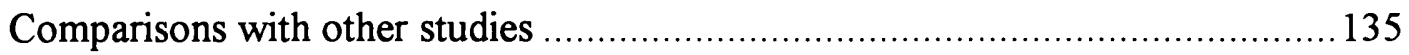

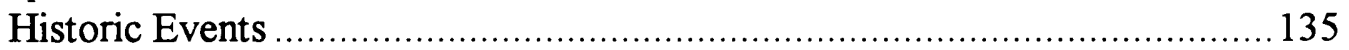

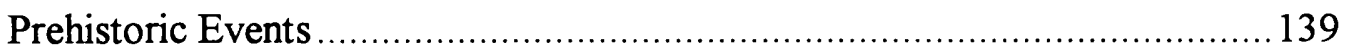

Implications for Evacuation ........................................................... 140

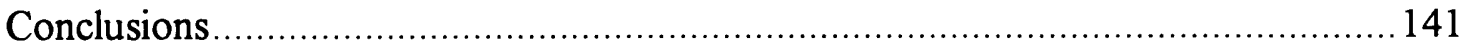

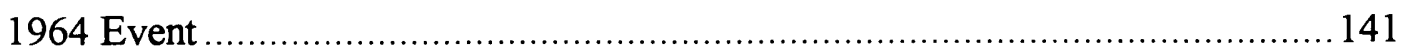

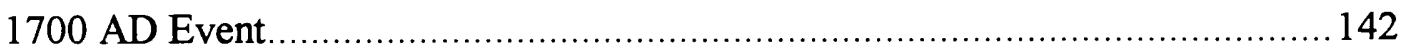

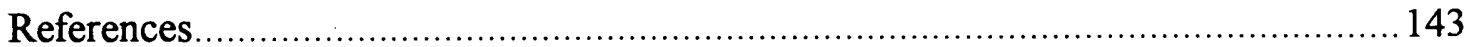

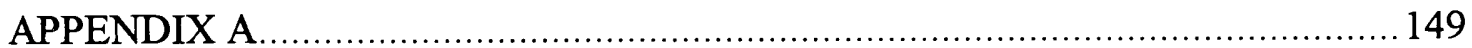

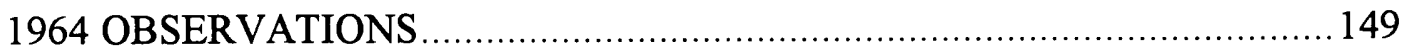

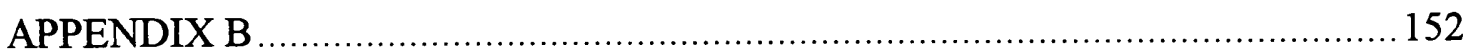

GOUGE CORE LOG LOCATIONS AND DESCRIPTIONS ..................... 152

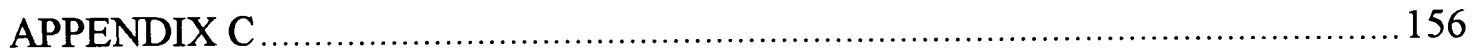

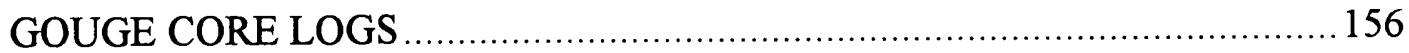

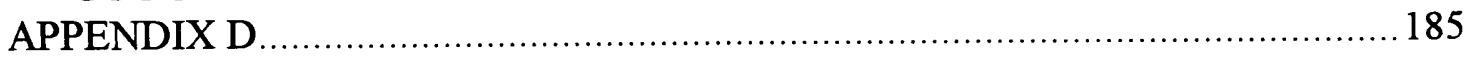

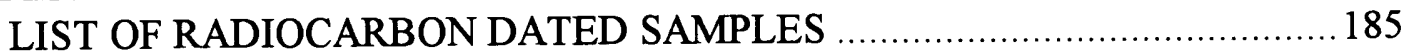

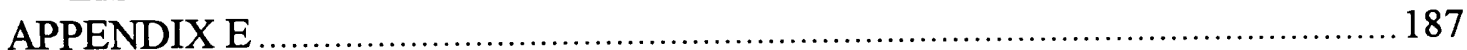

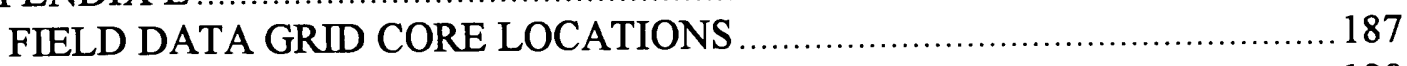

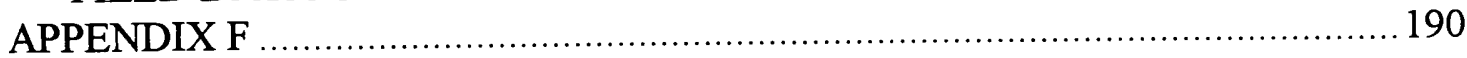

FIELD DATA GRID CORE LOGS ............................................... 190 


\section{List of Figures}

Number Page

FIGURE 1. CASCADIA SUBDUCTION ZONE AND PLATE CONFIGURATION.

FIGURE 2. STUDY AREA LOCATION OF SEASIDE, OREGON.

FIGURE 3. SEASIDE COASTAL WETLANDS.

FIGURE 4. LEWIS AND CLARK SKETCH MAP OF THE SEASIDE AREA

FIGURE 5. THREE NATIVE AMERICAN MIDDEN SITES

FIGURE 6. COASTAL WETLANDS OF SEASIDE STUDIED FOR HISTORIC AND PREHISTORIC TSUNAMI EVIDENCE..

FIGURE 7. OBSERVATION SITES AND CORE LOCATIONS FROM THE NECANICUM RIVER MOUTH TO 12TH AVE. BRIDGE.

FIGURE 8. OBSERVATION SITES AND CORE LOCATIONS FOR THE NECANICUM RIVER FROM 12TH AVE. TO BROADWAY DR.

FIGURE 9. OBSERVATION SITES AND CORE LOCATIONS FOR THE NECANICUM RIVER FROM BROADWAY DR. TO THE ISLANDS (AVE. S).

FIGURE 10. OBSERVATION SITES AND CORE LOCATIONS FOR THE NECANICUM RIVER FROM NECANICUM ISLANDS (AVE. S) TO THE COVE/GOLF COURSE (AVE. U). 33 FIGURE 11. NORTHERN NECANICUM RIVER CORES SSN 871, 870, 863; SHOWING A 1964 SAND DEPOSIT.

FIGURE 12. CENTRAL NECANICUM RIVER CORES SSN 759, 750, 747, 737; SHOWING A 1964 DEPOSIT.

FIGURE 13. SOUTHERN NECANICUM RIVER CORES SSN 731, 882, 884, AND 877; SHOWING THE THINNING OF THE 1964 DEPOSIT.

FIGURE 14. NORTHERN NECANICUM RIVER TRENCH 3A (CORE SITE SSN 864). 
FIGURE 15. CENTRAL NECANICUM RIVER TRENCH 3B (CORE SITE SSN 748). 39

FIGURE 16. SOUTHERN NECANICUM RIVER TRENCH 3C (CORE SITE SSN 732).

FIGURE 17. NEACOXIE CREEK OBSERVATION SITES AND CORE LOCATIONS.

FIGURE 18. NEACOXIE CREEK EAST BANK CORES SSX 754 AND 770.

FIGURE 19. NEACOXIE CREEK WEST BANK CORES SSX 771-774. 47

FIGURE 20. NEACOXIE CREEK GRID CORE LOCATIONS.

FIGURE 21. NEACOXIE CREEK EAST BANK N-S GRID CROSS-SECTION (SSX III, VII, VIII, IX, X, XI, XXVII, AND XXVIII)

FIGURE 22. NEACOXIE CREEK WEST BANK GRID CORES (SSX XIII, XX, XXI, XXII, XXV, XXVI)

FIGURE 23. NEACOXIE CREEK E-W CROSS-SECTIONS, NORTHERN CORES (SSX III AND XVIII).

FIGURE 24. NEACOXIE CREEK E-W CROSS-SECTION, CENTRAL CORES (SSX VI AND $\mathrm{XXI})$.

FIGURE 25. NEACOXIE CREEK E-W CROSS-SECTION, SOUTHERN CORES (SSX X AND XXVI).

FIGURE 26. NEACOXIE CREEK TRENCH 2A (CORE SITE SSX 754).

FIGURE 27. NEACOXIE CREEK TRENCH 2B (GRID CORE SITE SSX X).

FIGURE 28. DRAINAGE TO EAST OF NEACOXIE CREEK AND VENICE PARK OBSERVATION AND CORE SITES.

FIGURE 29. HOUSE LOCATED ON 26TH AND PINE IN VENICE PARK AREA.

FIGURE 30. DRAINAGE TO EAST OF NEACOXIE CREEK, CORES SSXA 853, 855-856.

FIGURE 31. DRAINAGE TO EAST OF NEACOXIE CREEK, TRENCH 4A (CORE SITE SSXA 850).

FIGURE 32. DRAINAGE TO EAST OF NEACOXIE CREEK, PREHISTORIC HORIZONS? 
FIGURE 33. STANLEY LAKE CORE LOCATIONS.

FIGURE 34. STANLEY LAKE CORES SSS 733 AND 734.

FIGURE 35. STANLEY LAKE CORES SSS 879-881.

FIGURE 36. STANLEY LAKE CORES SSS 866-868.

FIGURE 37. STANLEY LAKE CORES SSS 872-876.

FIGURE 38. STANLEY LAKE CORES SSS 887-889.

FIGURE 39. NEAWANNA CREEK OBSERVATION AND CORE LOCATIONS BETWEEN ITS MOUTH AND 12TH AVE.

FIGURE 40. NEAWANNA CREEK OBSERVATION SITES AND CORE LOCATIONS FOR 12TH AVE. TO SOUTH OF THE BROADWAY DR. BRIDGE.

FIGURE 41. NEAWANNA CREEK CORES SSW 722, 723, 725, AND 726.

FIGURE 42. NEAWANNA CREEK CORES SSW 718-720.

FIGURE 43. NEAWANNA CREEK CORES SSW 757, 756, 763.

FIGURE 44. NEAWANNA CREEK CORES SSW 803-808.

FIGURE 45. NEAWANNA CREEK OBSERVATION SITES AND CORE LOCATIONS FROM SOUTH OF BROADWAY DR. TO S AVE.

FIGURE 46. NEAWANNA CREEK GRID LOCATION MAP.

FIGURE 47. NORTHERN SSW GRID CORES I-V, VIII, AND X.

FIGURE 48. E-W CROSS-SECTION OF THE CENTRAL SSW GRID CORES XIII, XIV, XVI, AND XVIII.

FIGURE 49. SOUTHERN SSW N-S GRID CORES XXVIII, XXVII, XXVI, AND XXIX.

FIGURE 50. SOUTHERN SSW E-W GRID CORES XXVIII, XXII, AND XXI.

FIGURE 51. NEAWANNA CREEK TRENCH 1A.

FIGURE 52. NEAWANNA CREEK TRENCH IB.

FIGURE 53. NEAWANNA CREEK CORES SSW 720, 716, 717, 714, AND 781. 
FIGURE 60. NEAWANNA CREEK OBSERVATION SITES AND CORE LOCATIONS FROM S

AVE. TO THE MILL PONDS.

FIGURE 61. NEAWANNA CREEK CORES SSW 735, 730, 828, 830, 831, 832.

FIGURE 62. LOCATIONS OF COBBLE RIDGES EXTENDING THROUGHOUT SEASIDE. $\quad 104$ FIGURE 63. AREAS IN SEASIDE AFFECTED BY WAVE AMPLIFICATION DURING THE 1964 TSUNAMI.

FIGURE 64. SEASIDE WETLANDS AFFECTED BY TSUNAMI ATTENUATION DURING THE 1964 EVENT.

FIGURE 65. 1964 SSX GRID ISOPACH, DETERMINING THICKNESS OF THE SAND SHEET IN SEASIDE.

FIGURE 66. 1964 SSW GRID ISOPACH, DETERMINING THICKNESS OF THE SAND SHEET IN SEASIDE.

FIGURE 67. 1964 OBSERVATION SITES AND GOUGE CORE DEPOSIT LOCATIONS INCLUDING 1964 INUNDATION LINE.

FIGURE 68. DISTRIBUTION OF LIS RELATED TO THE 1700 AD EVENT LIQUEFACTION ZONES IN THE SEASIDE WETLANDS.

FIGURE 69. ARROWS INDICATING PROPAGATION WHICH POSSIBLY OCCURRED DURING THE 1700 AD EVENT IN SEASIDE. 


\section{List of Tables}

Number $\quad$ Page

TABLE 1. VISUAL ESTIMATION OF ORGANIC MATERIAL 19

TABLE 2. RADIOCARBON SAMPLES AND CORE LOCATIONS 21

TABLE 3. DIATOM SAMPLES ANALYZED 23 


\section{Introduction}

Subduction zone earthquakes (Mw 8-9) along the Pacific Northwest region of North America (Figure 1) result from the dislocation of the Cascadia megathrust between the subducting Juan de Fuca oceanic plate and the overriding North American continental plate (Heaton and Kanamori, 1984). Coseismic uplift or subsidence of the ocean floor during a megathrust earthquake produces a vertical displacement of the water column, resulting in tsunami propagation (Atwater, 1987; Darienzo and Peterson, 1990). The Cascadia subduction zone extends from southern British Columbia to northern California, making the adjacent Pacific coast and major population centers susceptible to severe earthquakes and potentially disastrous tsunami.

Seaside, Oregon, a northern Oregon coastal community (Figure 2), has the potential to be substantially impacted by a megathrust earthquake and subsequent tsunami. The elevation of Seaside ranges from four meters at the ocean waterfront to eight meters at the base of the foothills, which bounds the beach plain to the east. The population vastly increases from the 6,000 permanent residents to 60,000 tourists during peak summer weekends. Many hotels and tourist accommodations are set near beachfront property.

Seaside suffered significant damage from a farfield tsunami (March 27, 1964) that was generated by a subduction zone earthquake focused near northern Prince William Sound, Alaska (NAS, 1971,1972; Griffin, 1984). Seaside's city council estimated $\$ 46,000$ worth of damage (at 1964 costs) to the city's property along the Necanicum 


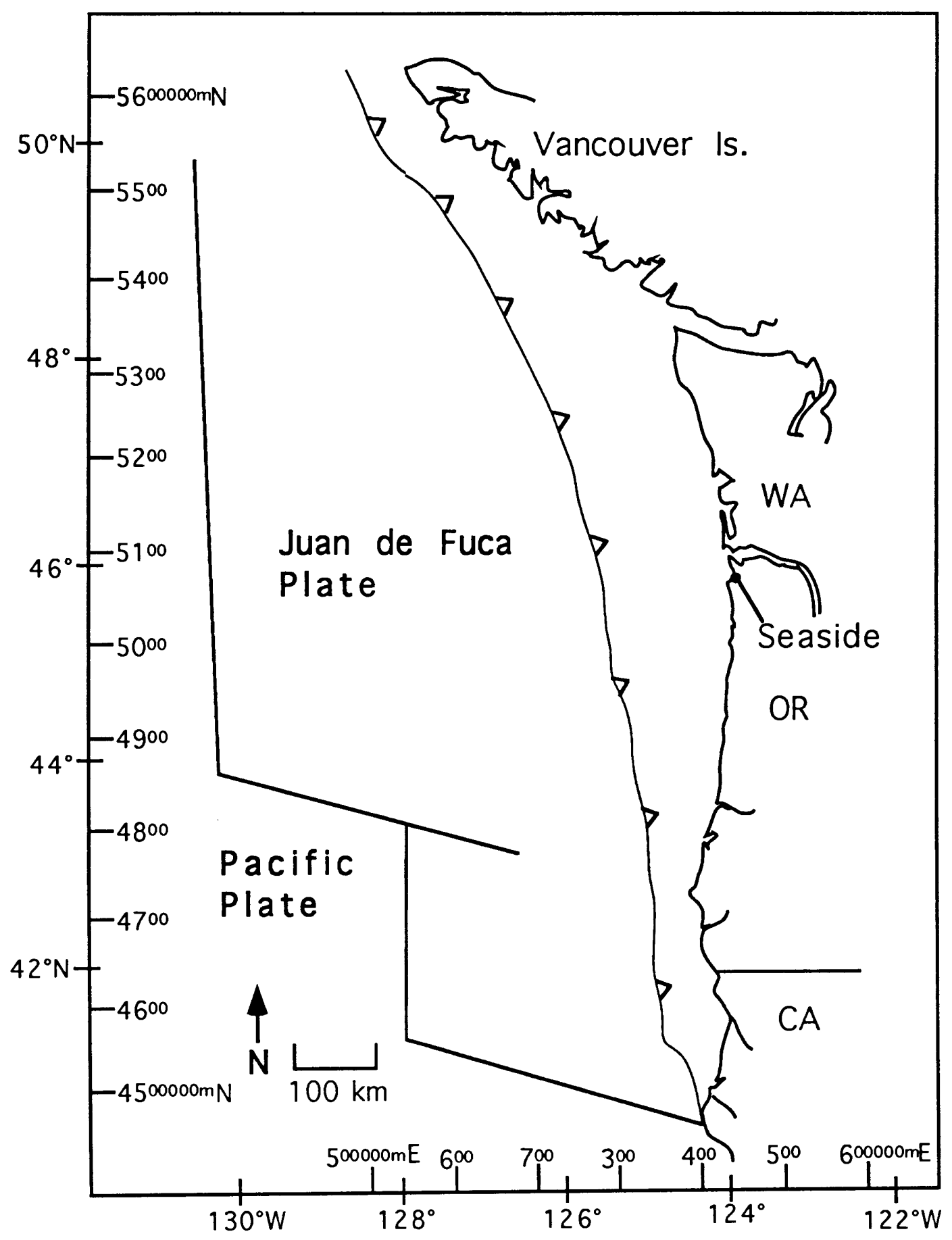

Figure 1. Cascadia subduction zone and plate configuration. Triangles on the solid line represents the trench between the descending oceanic plates and the over-riding North American plate. Straight line segments west of the trench represent the spreading ridge and transform faults. 


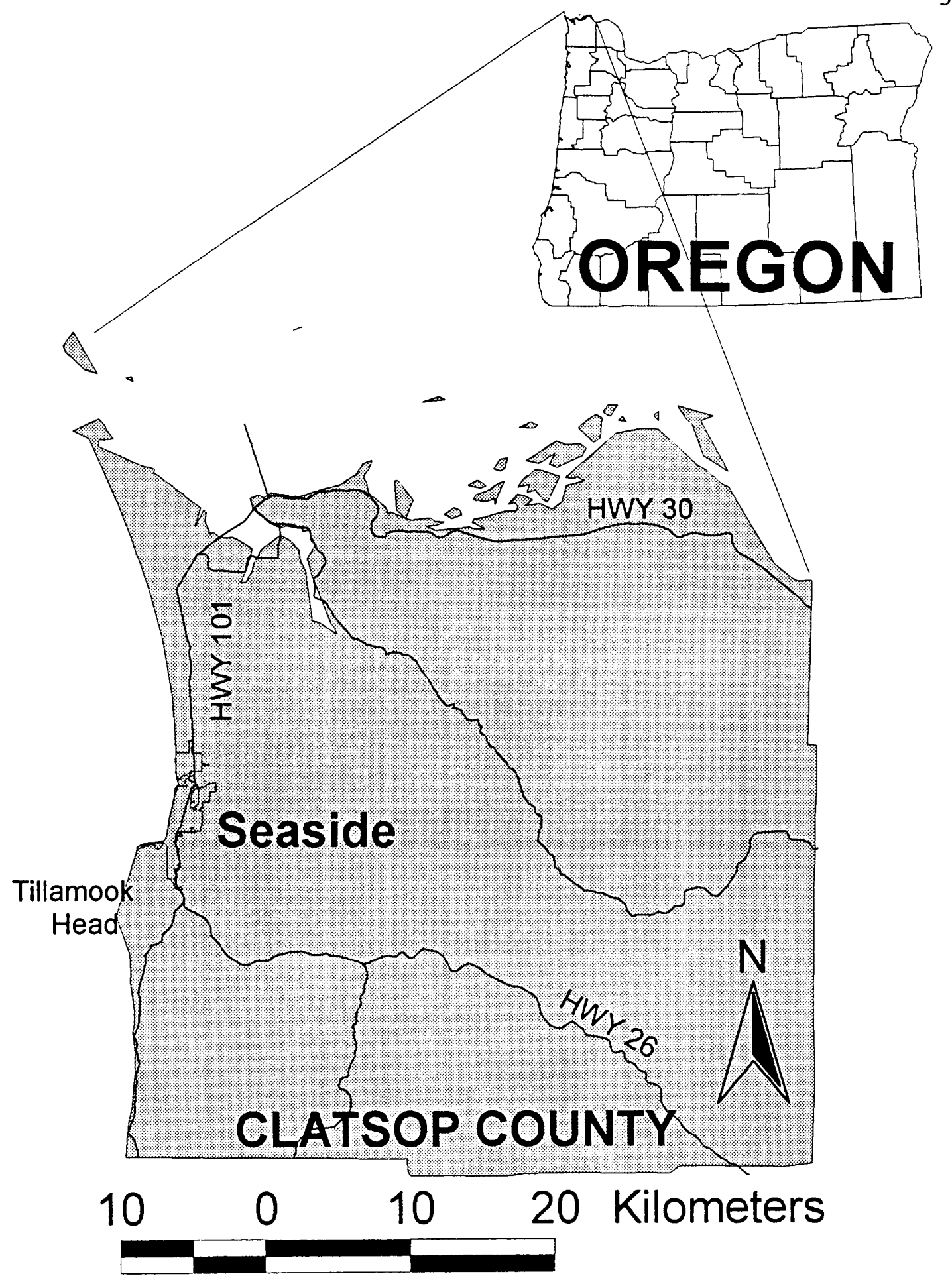

Figure 2. Study area location of Seaside, Oregon. 
River, Venice Beach, and shoreline (Seaside Signal, April 2, 1964), and \$235,000 damage to private property along the Necanicum and Neawanna channels (Lander and others, 1993). Exceptional tsunami damage at Seaside relative to other coastal Oregon communities might have resulted from local amplification, as reported for Port Alberni, British Columbia and Crescent City, California (Griffin, 1984; Lander and others, 1993; Clague and others, 1994).

Nearfield paleotsunami evidence has been found in the coastal wetlands of Seaside (Darienzo, 1991; Darienzo and others, 1993). Evidence for nearfield paleotsunami inundation in Seaside and other backbarrier tidal wetland sites in northern Oregon consists of thin sand layers located between underlying muddy peats and overlying rooted muds. A three step process produces this peat and sand combination. First, coseismic subsidence occurs, associated with dislocation of the megathrust. Second, the tsunami wave washes over the wetlands and deposits the entrained sand. Finally, intertidal mud, then peat covers the deposited sand.

Several computer models have been developed to predict possible runup from a nearfield (Cascadia) tsunami inundating the Seaside area (Whitmore, 1993; Myers, 1994). Geologic evidence of nearfield tsunami inundation is needed to verify and calibrate these computer simulations.

Increasing government and public attention is now being focused on mitigation of potential tsunami runup in the Pacific Northwest coast. The Department of Oregon Geology and Mineral Industries (DOGAMI) has produced coarse-scale inundation 
maps of the entire Oregon coast (Priest, 1995). Myers (in progress) is creating new computer models for both Cascadia subduction zone tsunami and the 1964 Alaskan tsunami runup in Seaside and adjacent coastal areas. Several coastal towns are developing tsunami evacuation routes (Visher, 1995).

This study focuses on the geologic evidence of tsunami inundation in Seaside, Oregon. Specifically, historic 1964 and prehistoric $1700 \mathrm{AD}$ events are analyzed. Results presented in this study include logs of shallow cores taken throughout the coastal wetlands of Seaside that record evidence of deposition from historic and prehistoric tsunami. Analysis of these cores includes the determination of lithostratigraphy, sedimentary structures, radiocarbon age, and microfossil paleotidal indicators. The results of these analyses are used to map nearfield paleotsunami inundation in the Seaside wetlands. The inundation maps also address potential mechanisms of maximum inundation, for example, channel surge or barrier overtopping in Seaside. 


\section{Background}

\section{Tsunami Generation in Subduction Zones}

Interactions between the Pacific plate and the continental plates surrounding it cause the entire Pacific rim to be tectonically active. Two results of this tectonism are volcanoes and earthquakes. Earthquakes in excess of Mw 8 (called great earthquakes) may result in a large vertical displacement of water generated by sudden uplift or subsidence of the ocean floor and/or sudden coseismic subsidence of adjacent coastal land (Lander and others, 1993; Ingmanson and Wallace, 1995). Coseismic subsidence occurs from the release of convergent tectonic strain accumulated in the coastal margin of the continental plate. When the oceanic plate slips under the continental plate during a coseismic dislocation of the megathrust, the strain is released by 1) regional subsidence landward of the zero-isobase, 2) regional uplift seaward of the zero-isobase, and 3) local uplift or subsidence associated with faulting in the upper plates (Plafker, 1972; Heaton and Hartzell, 1987; Barnett, 1997).

Once vertically displaced, the water attempts to regain equilibrium by forming long-period surge waves. These waves, called tsunami, are defined as shallow-water gravity waves traveling at a velocity, $v$, proportional to the square root of water depth,

$\mathrm{d}$, and gravitational constant, $\mathrm{g},(v=\sqrt{g d})$. Tsunami may have periods ranging from 6 to $60+$ minutes and are capable of traveling across ocean basins and propagating along coastal margins. Amplitudes of the waves may range from a few centimeters to over $30 \mathrm{~m}$ depending upon the amount of vertical displacement caused by the generating 
event and the depth of water. Depending on near-shore bathymetry and wave momentum, the runup height of the waves on coastal land commonly exceeds the wave amplitude, and a tsunami's impact on coastal regions will be locally greater in some areas than in others (Lander and others, 1993; Myers, 1994).

Tsunami are relatively rare events, occurring on average once per year somewhere in the Pacific basin. Most of these events are small enough that they can only be distinguished from normal tides by tide gauges. Tsunami large enough to damage coastal towns occur about once every ten years somewhere on the Pacific margin. With settlement along coastal areas increasing, the frequency and amount of damage from tsunami is likely to rise. (Lander and others, 1993)

\section{Cascadia Margin Neotectonics}

Over the past decade, the Cascadia subduction zone has been recognized as a potential source of great undersea earthquakes. The geologic records of these great earthquakes, which include shaking induced liquefaction, tsunami, and subsidence, have been studied by many investigators (Heaton and Kanamori, 1984; Clague and Bobrowsky, 1994; Atwater and others, 1995; Charland and Priest, 1995, Satake and others, 1996). The megathrust earthquakes produced along the Cascadia subduction zone, which extends $1200 \mathrm{~km}$ from southern British Columbia to northern California, result from the subduction of the Juan de Fuca oceanic plate below the North American continental plate (Figure 1). The active Cascade volcanoes provide evidence that subduction continues below the North American plate (Wilson, 1989). Subduction 
occurs at an estimated rate of $4 \mathrm{~cm} / \mathrm{yr}$. (Heaton and Hartzell, 1987). Interplate earthquakes produced at the Cascadia subduction zone are so proximal to the coast that delay times, and therefore warning times, between earthquake and tsunami may be only 15-20 minutes, as opposed to farfield events with travel times of hours (Atwater and others, 1995). The Cascadia subduction zone was first identified by T. Atwater in 1970, but it was not until 1987 that B. Atwater reported evidence for coseismic subsidence and associated tsunami inundation at several southwestern Washington coastal bays.

Geologic records of paleoseismicity in the Cascadia subduction zone indicate that great earthquakes are rare events. The most recent great earthquake occurred about $1700 \mathrm{AD}$ (Atwater and others, 1995). Dendrochronological records from drowned trees in the coastal wetlands of the Cascadia margin (Yamaguchi and others, 1989; Jacoby and others, 1992), and farfield tsunami runup records in Japan (Satake and others, 1996) support this estimated age of the last Cascadia event. Older geologic records suggest that recurrence intervals for Cascadia events are on the order of 200 to 600 years (Darienzo and others, 1993; Atwater and others, 1995). Peterson and others (1991) and Darienzo and Peterson (1995) estimate a 10-20 percent chance that a great earthquake producing a tsunami will occur in the next 50 years.

Historic Records of Subduction Zone Generated Tsunami

Heaton and Hartzell (1987) indicate many similarities between the Cascadia subduction zone and other subduction zones around the world, particularly those at 
southwestern Japan, Columbia, and southern Chile. These locations contain young oceanic lithosphere prone to large, shallow, thrust earthquakes. Large local tsunami have occurred in areas roughly analogous to the Cascadia subduction zone. Earthquakes in Japan in 1944 (Mw 8.1) and $1946(\mathrm{Mw}$ 8.1) generated local tsunami with maximum runup heights of 7.5 and $6.0 \mathrm{~m}$, respectively. Columbia and northern Equador experienced an earthquake-generated tsunami in 1906 which caused extensive damage along the coastal areas. The Chilean earthquake in 1960 produced one of the largest tsunami in historic times, with damage caused not only locally but in Japan and Hawaii as well. Local runup for the Chilean earthquake reached a maximum of $20 \mathrm{~m}$. However, coastal areas close to the epicenter experienced runup heights less than ten meters (Heaton and Hartzell, 1987).

Finally, runup in the Prince William Sound area for the 1964 Alaskan earthquake was 9-12 $\mathrm{m}$ above the prevailing low tide. The Patton Bay fault, located at the southern end of Prince William Sound, uplifted crustal blocks relative to sea level. A western block was upthrown eight meters above an eastern block. Corresponding tilting of Prince William Sound to the northwest created local amplification and seiching in fjords. Both the local faulting and local amplification substantially increased local runup above regional heights. (NAS, 1972)

\section{Pacific Northwest Impacts}

Several studies investigating coseismic subsidence and tsunami deposits have been done throughout the Pacific coast, extending the length of the Cascadia 
subduction zone. Atwater (1987) first introduced evidence for great subduction earthquakes in the coastal marshes of Willapa Bay, southwestern Washington where sandy layers cover three buried lowlands which are sand free deposits. These sand sheets become thinner and finer grained landward, suggesting a bayward source rather than stream flooding.

Clague and Bobrowsky (1994) describe sand deposits within peats and muds in tidal marshes on Vancouver Island, British Columbia, Canada. These areas contain both historic and prehistoric tsunami deposits. Distinguishing characteristics of these sand layers include sharp upper and lower contacts, massive sand and silty sand, and detrital wood and plant debris. Some of the prehistoric deposits imply much larger events than the 1964 Alaskan event. (Clague and Bobrowsky, 1994)

In Oregon, Peterson and others (1993) produced a field trip guide for the central Cascadia margin involving sites of paleotsunami deposits in Siletz Bay, Nestucca Bay, Netarts Bay, Cannon Beach, Seaside, and Youngs Bay (Columbia River). Netarts Bay core sections contain Cascadia earthquake evidence dating back to $3 \mathrm{Ka}$ in the form of buried peats with overlying sand. The stratigraphy is considered the type section for paleoseismological evidence in the northern Oregon coast (Peterson and others, 1993). Peterson and Priest (1995) completed a reconnaissance investigation of the tidal marshes along Yaquina Bay for paleotsunami evidence. Peterson and others (1996) completed an extensive study producing a tsunami hazard map and explanation of the 
Siletz Bay area. Peterson and Gallaway (in progress) have determined prehistoric nearfield tsunami inundation at Cannon Beach, Oregon.

\section{Alaskan Tsunami Impacts in Pacific Northwestern Region}

Since no written record exists for prehistoric events such as the $1700 \mathrm{AD}$, studies and records of more recent tsunami events become especially significant. The current historical record for the Pacific coast consists only of farfield tsunami (Charland and Priest, 1995), chiefly the 1964 tsunami caused by a Mw 9.2 earthquake centered in the northern Prince William Sound of Alaska (NAS, 1971; Lander and others, 1993; Clague and Bobrowsky, 1994). This distal earthquake produced a Pacific wide tsunami which reached the shores of Antarctica (NAS, 1972). The most damaging inundation along the U. S. coast occurred in areas of Alaska and Crescent City, California. Landslides in Anchorage, caused the majority of the damage in Alaska, but most fatalities resulted from the tsunami runup. Out of the 115 people killed in Alaska, 106 deaths were tsunami related (NAS, 1972).

This earthquake generated tsunami of March 27, 1964 devastated the waterfront in Crescent City, California. Eye-witnesses reported surge crests of at least six meters in height. Between midnight and $2 \mathrm{AM}$ on March 27th, four separate wave surges occurred. The waves carried logs and cars several hundred meters inland. The surges damaged numerous buildings along the harbor waterfont and along exposed beach ridges to the south of town. A total of 29 city blocks were hit, 289 homes and 
businesses damaged or destroyed, and 11 people killed. Repair costs exceeded $\$ 16$ million in 1964 (Griffin, 1984).

The tsunami waves from the 1964 Alaskan earthquake crashed upon the shores of Seaside with little to no warning. According to the April 2, 1964, edition of the Seaside Signal, estimates of the wave height were three meters. The majority of the bridges crossing the Necanicum River suffered severe damage, and the already condemned 4th Avenue bridge was completely washed out. The waves threw automobiles against houses, a home shifted off its foundation, and appliances and furniture shifted about. Even the SP\&S railroad trestle crossing near the mouth of Neawanna Creek lost all supporting pilings when the water raged past. Fortunately, no deaths or major injuries occurred.

\section{Study Area}

Seaside is a northern Oregon coastal community of roughly 6,000 permanent residents, located in Clatsop County just north of Tillamook Head and south of Astoria and the Columbia River mouth (Figure 2). The study area involves the coastal wetlands in the Seaside area including the Necanicum River, Neawanna Creek, Neacoxie Creek, and Stanley Lake (Figure 3). These wetlands extend as much as 1.5 kilometers inland from the present ocean shoreline.

Significant local amplification of the 1964 tsunami waves occurred at Port Alberni, British Columbia, Crescent City, California, and Seaside, Oregon. The entire Oregon coast felt the effects of tsunami impacts, however, Seaside received significant damage in the bay mouth areas. The physiography of Tillamook Head, the Columbia 


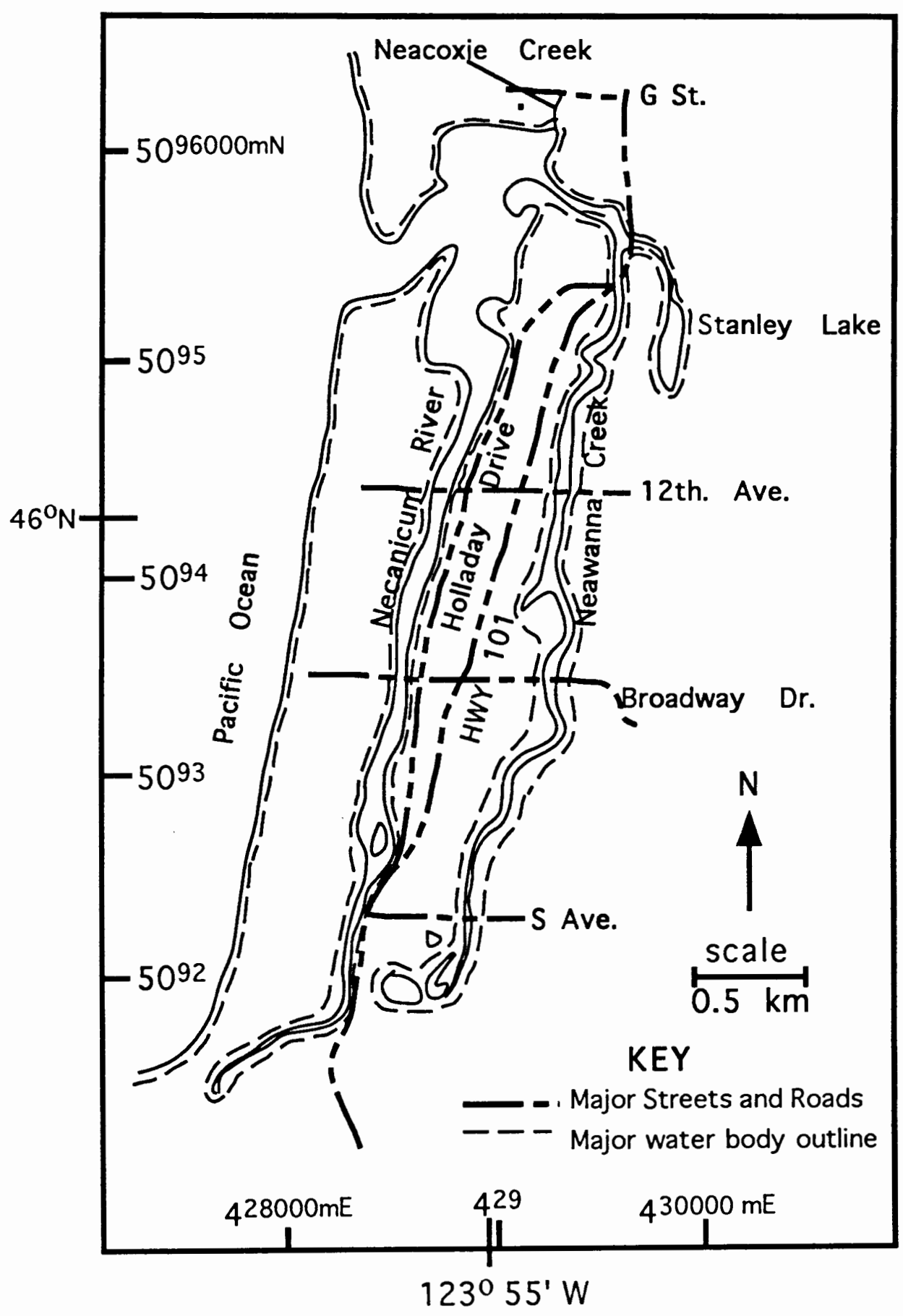

Figure 3. Seaside coastal wetlands. 
River ebb delta-shoal, and the construction of the Necanicum bay mouth could have contributed to the local amplification of the 1964 tsunami in Seaside (Myers, 1994; Myers, personal communication, 1996). Lewis and Clark sketch maps (Thwaites, 1905), native American midden sites, and cobble ridges in Seaside all help establish the morphology of the coast that was affected by late-prehistoric tsunami. Lewis and Clark completed the first maps of Seaside during their expedition west in 1805-1806 (Thwaites, 1905). However, their sketch map (Figure 4) does not show Neawanna Creek, and the Necanicum River has apparently changed morphology during the last 200 years. Also, at the time of the Lewis and Clark expedition, native Americans lived along the beaches in Seaside (Thwaites, 1905). Connolly (1992; 1995) and Phebus and Drucker (1979) have done extensive anthropological studies on three native American midden sites in Seaside. They believe that at one time there was an embayment near the southern end of Seaside. All three midden sites, Avenue Q, Par-tee, and the Palmrose (Figure 5), contain bay clam shells not found in the Necanicum River near these sites in Seaside today.

Rankin (1983) examined the processes of the prograding dunes of northern coastal Clatsop County and the cobble ridges of Seaside. The N-S trending cobble ridges of Seaside have aligned the interdune valleys containing Neawanna Creek and the Necanicum River. The primary sources of the clasts are from both Tillamook Head and the Necanicum River. Storm waves deposited the cobbles as parallel beach ridges. Knowing the locations and trends of these ridges provides a better understanding of the 


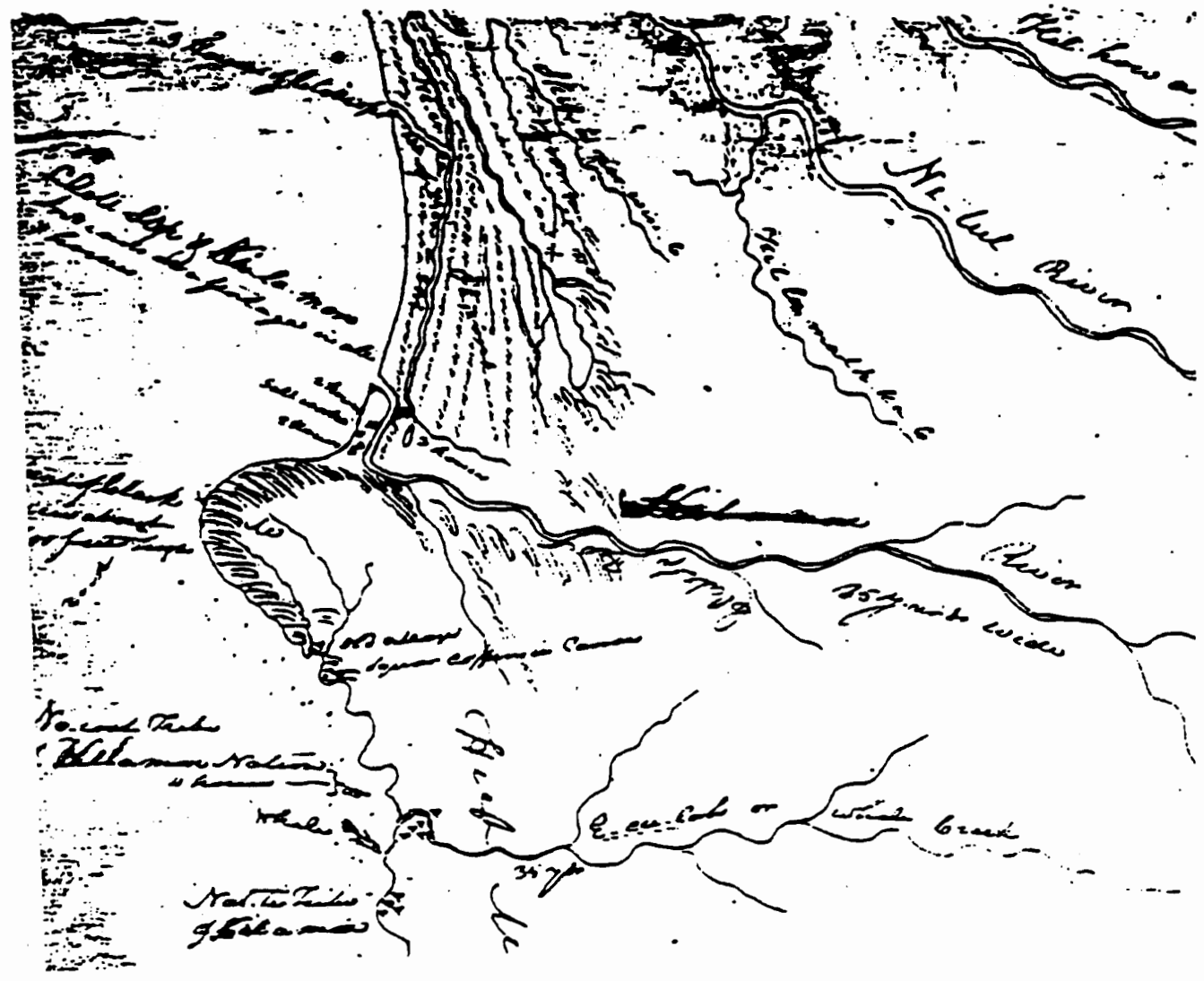

Figure 4. Lewis and Clark sketch map of the Seaside area, expedition of 1805-1806 (Thwaites, 1905). 


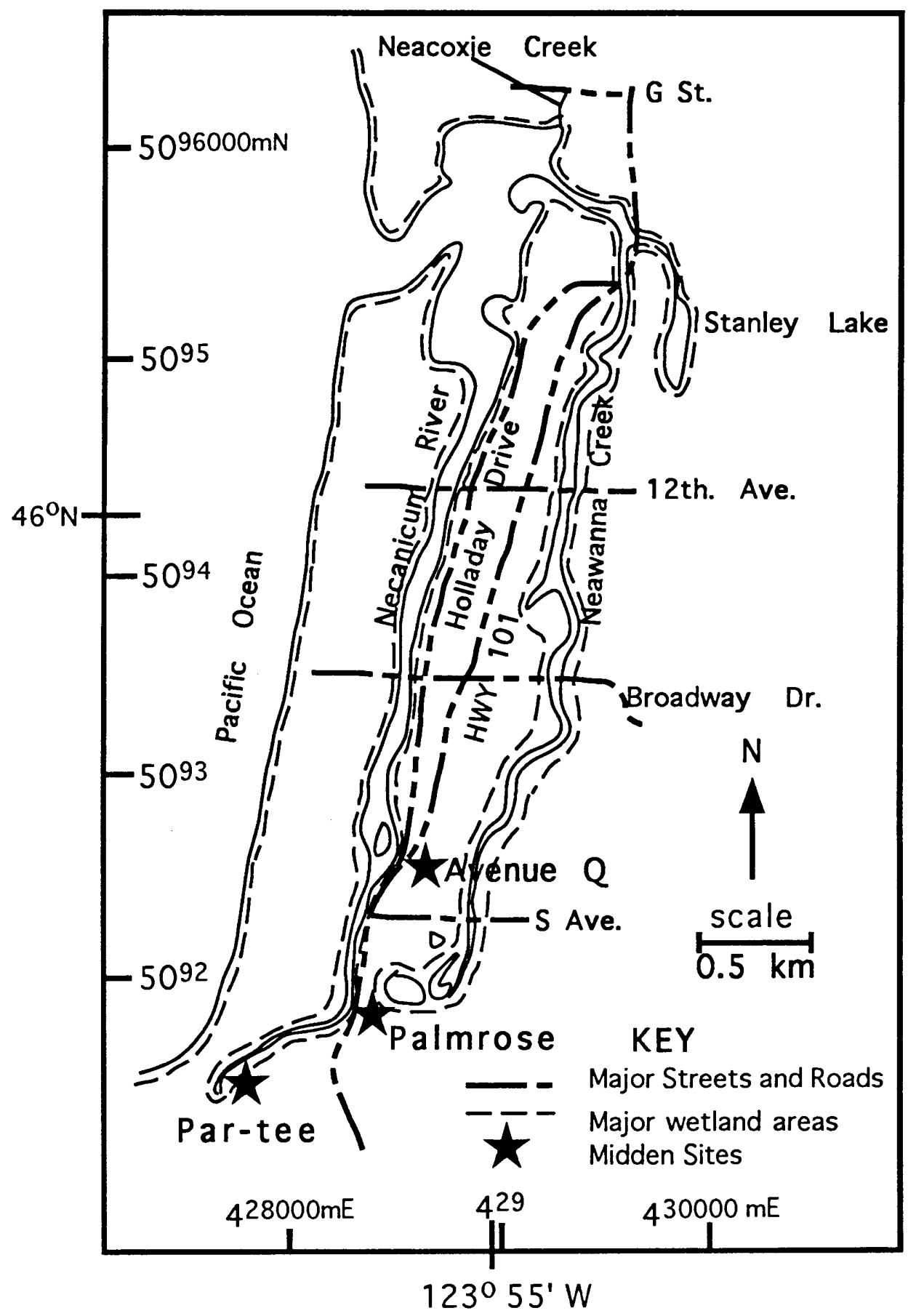

Figure 5. Three native American midden sites located in the Seaside area. 
morphology of the Seaside coastline in prehistoric times.

Darienzo (1991) and Darienzo and others (1993) completed a preliminary tsunami study in the Seaside area. Evidence for the prehistoric tsunami was found primarily in the wetlands of Neawanna Creek and Stanley Lake. This study follows the work of Darienzo, including much additional coring at and between Darienzo's reported core sites. Some radiocarbon dates and interpretations reported by Darienzo are included under the Results section of this study and are cited where used. 


\section{Methods}

Coastal wetlands of Seaside, Oregon, consist of the Necanicum River, Neawanna Creek, Neacoxie Creek, and Stanley Lake. These low lying areas represent protected environments with high potential to preserve evidence of coseismic subsidence and tsunami inundation. Extensive reconnaissance coring of these back barrier sites involved obtaining samples from up to three meters in depth with gouge cores $(25 \mathrm{~mm}$ diameter, $1 \mathrm{~m}$ length core barrel, plus additional $1 \mathrm{~m}$ extensions). Pound cores (aluminum $7.5 \mathrm{~cm}$ diameter tube cut to desired length, pounded into the ground by sledge hammer, and pulled out by hand winch) yielded generally undisturbed sections for radiocarbon and diatom analysis. All cores were logged at one centimeter intervals for sediment lithology, special characteristics such as grading and laminations, and contact relationships. Visual estimates of organic content define mud and peat lithologies according to the standards given by Briggs, 1994 (Table 1). Sand layers are of significant interest, and when found are examined for sorting, grading, and abruptness of contacts above and below. Sand layers deposited by a tsunami should display characteristics of rapid deposition, such as sharp basal contacts and fining upward sequences (Darienzo and Peterson, 1990; Darienzo, 1991; Clague and Bobrowsky, 1994; and Atwater and others, 1995). Examination of contact relationships distinguishes between changes in depositional environment caused by coseismic subsidence, uplift, or gradual submergence. Sharp contacts $(<0.5 \mathrm{~cm})$ between peat and the overlying mud can result from abrupt subsidence. Gradual 
contacts $(>0.5 \mathrm{~cm})$, such as a muddy peat grading upward into a peaty mud, indicate slowly changing depositional environments. However, minor coseismic subsidence $(<1.0 \mathrm{~m})$ occurring in dilute-brackish settings creates a gradual lithologic contact. Coseismic subsidence under such settings can be confirmed by sharp contacts between brackish and freshwater diatoms, which respond quickly to changes in environmental salinity (Barnett, 1997; Peterson and others, 1997). Intruded contacts show irregular lithologic interfaces, for example between sand and mud or peat. These contacts produced by sand fluidization and injection can result from coseismic liquefaction.

Table 1. Visual Estimation of Organic Material

\begin{tabular}{ccc} 
Lithology & $\%$ Organics & Marsh Environment \\
\hline peat & $>80 \%$ & very high marsh or forest \\
muddy peat & $80-50 \%$ & high marsh \\
peaty mud & $50-10 \%$ & transitional marsh \\
rooted mud & $10-5 \%$ & colonizing marsh \\
mud & $<5 \%$ & barren tidal flat \\
\hline
\end{tabular}

Locations of initial cores taken in this study were selected to confirm the work by Darienzo (1991) and Darienzo and others (1993). Aerial photos, topographic maps, and orthophoto maps were used to identify additional wetland sites for examination by coring, trenching, and cutbank examination.

Core locations were field plotted on orthophoto contour base maps (scale 1:1200) (Wegner, 1973). Some core positions, particularly those sites in extreme tree 
and brush cover were located with a Garmin GPS 45 XL (GPS = Global Positioning System) personal navigator connected to a real-time differential receiver, tuned to the Fort Stevens Coast Guard beacon. Accuracy of core site positions from both the large scale orthophotos and the real-time differential GPS is 3-10 m. All core locations are given both as UTM and NAD 1927 State Plane coordinates, and the program CORPSCON v.4.11 created by the US Army Topographic Engineering Center (TEC) was used to convert these coordinates.

Core locations along the upper Neawanna and Neacoxie Creeks contain very dense sand deposits which required an Australian sand auger $(43 \mathrm{~cm}$ length, $7 \mathrm{~cm}$ diameter cylinder with a $1 \mathrm{~m}$ length handle) to penetrate, allowing the identification of sediments below.

Radiocarbon samples were collected from trenches or pound cores, allowing for an undisturbed stratigraphic section. Ideal samples for radiocarbon dating included small sticks and spruce or pine cones in contact with the target tsunami sand layers. Less ideal samples included peaty sections several centimeters in thickness below the target tsunami sand layers. The ${ }^{14} \mathrm{C}$ samples were collected, labeled, and sealed in plastic bags. Sample preparation included: 1) washing the sample with deionized water, 2) removing noticeable root-hairs from the woody fragments, 3) drying, weighing, and packaging the sample in aluminum foil, and 4) sending them to a commercial laboratory (Beta Analytic, Inc.) for ${ }^{14} \mathrm{C}$ dating analysis. This company treated the samples with an acid/alkali/acid pretreatment, removed any additional root- 
hairs, and analyzed for radiocarbon. Standard radiocarbon testing was done along with the ${ }^{12} \mathrm{C} /{ }^{13} \mathrm{C}$ isotopic ratio analysis. Seven locations provided eight bulk and two Accelerator Mass Spectrometer (AMS) samples (Table 2). Darienzo (1991) and Darienzo and others (1993) radiocarbon results were also helpful in this study.

Table 2. Radiocarbon Samples and Core Locations

\begin{tabular}{|cccc} 
Location & Core Number & $\begin{array}{c}\text { Sample Location } \\
\text { (within section) }\end{array}$ \\
\hline Stanley Lake (SSS) & 879 & $55-65 \mathrm{~cm}$ \\
Neawanna Creek (SSW) & 879 & $54 \mathrm{~cm}$ \\
& 716 & $54 \mathrm{~cm}$ \\
& 716 & $81 \mathrm{~cm}$ \\
& 729 & $84 \mathrm{~cm}$ \\
Necanicum River (SSN) & 823 & $74 \mathrm{~cm}$ \\
\hline
\end{tabular}

Diatom samples reveal the abundance of fresh, brackish, and marine diatoms present in a restricted deposit interval. The samples analyzed in this study were taken directly from above and below the subsided contact $( \pm 1 \mathrm{~cm})$. Darienzo (1991) outlined the diatom taxa analysis and sample preparation. This process involved:

1. Placing a small portion of sample $(<5 \mathrm{~g})$ in a beaker with $25 \mathrm{ml}$ of deionized water. 
2. Organic fragments are removed by adding $20 \mathrm{ml}$ of $30 \% \mathrm{H}_{2} \mathrm{O}_{2}$ solution, and the samples are placed under a fume hood for 24 hours.

3. Sand fractions are removed by sieving the sample with a no. 230 sieve (63 $\mu \mathrm{m})$.

4. The sample is allowed to settle for 0.5 hours and then a $5 \mathrm{ml}$ sub-sample is taken.

5. One drop of the sub-sample is placed onto a clean glass slide and is diluted with 2 drops of deionized water.

6. The glass slide is placed on a hot plate at $50^{\circ} \mathrm{C}$ until the sample is dry.

7. A drop of Preservaslide (resin dissolved in Xylene) is placed on the glass slide and covered with a cover slip. Slides are stored in a horizontal position.

E. T. "Chip" Barnett completed the diatom sample analyses for this study (Table

3). The relative abundances of marine, brackish, and freshwater diatoms above and below the contacts were evaluated semi-quantitatively (Barnett, 1997). The results are used to establish whether the area was inundated with sea water following apparent subsidence.

To calibrate interpretations of the prehistoric tsunami deposits, several localities of 1964 tsunami deposits were investigated in detail. Forty two core sites (including 5 from Darienzo's study in 1993) were investigated along the banks of the Necanicum River from the mouth to the golf course to verify attenuation of tsunami deposit thickness upstream (Darienzo and others, 1993). Core grids, taken at 25 meter intervals, aided in clearly defining the extent and characteristics of the sand deposit from the 1964 event in different depositional settings. Grid areas chosen are: 
Neacoxie Creek from mouth to G Street (Gearhart) and three locations along the upper Neawanna Creek between 12th Avenue bridge and HWY. 101 bridge. The three grid areas show amplification or attenuation of the sand thickness from the 1964 event over small $0.1-0.5 \mathrm{~km}$ distances.

Table 3. Diatom Samples Analyzed

\begin{tabular}{lcc}
\multicolumn{1}{c}{ Location } & Core Number & $\begin{array}{c}\text { Sample Location } \\
\text { (depth in section) }\end{array}$ \\
\hline Stanley Lake (SSS) & 879 & $50-54 \mathrm{~cm}$ \\
Neawanna Creek (SSW) & 831 & $54-57 \mathrm{~cm}$ \\
Necanicum River (SSN) & $82 \mathrm{~cm}$ \\
$84 \mathrm{~cm}$
\end{tabular}

In addition to gouge core data for the 1964 event, profile trenches (dug by shovel with the sediment profile face cleaned by a putty knife) provided better exposures of the characteristics of a particular depositional layer. A north-south face and an eastwest face were sketched. These trenches, on the average of $50 \mathrm{~cm}$ width by $50 \mathrm{~cm}$ depth, provided a better three-dimensional view than the traditional gouge core.

Since the 1964 event occurred only 30 years ago, eye-witness accounts provide additional valuable information on water level runup and associated sediment deposition. Interviewing and recording of the eye-witness accounts were primarily 
done by Thomas Horning, Seaside resident and local geologist. Additional interviews were conducted by this author.

Mapping of cobble ridges which indicate paleoshoreline "beach ridge" positions was completed to aid in understanding the general paleogeography of Seaside. Observations of surface cobble deposits were made and placed on the 1:1200 orthophoto base maps of Seaside. The Clatsop Plains study by Rankin (1983) was also used in establishing the general location of the cobble ridges in Seaside.

Finally, ground penetrating radar (GPR) was used to investigate the nature of the subsurface deposits between prominent cobble ridges, where dense sand or shallow water table prevented gouge coring or sand augering. All GPR lines were directed by Harry Jol (University of Wisconsin - Eau Claire Geography Department) and Sandy Vanderburgh (University of the Fraser Valley - Abbotsford Department of Geography). Seaside High School athletic practice fields were chosen as one of the GPR study sites and three lines were run: one north-south and two east-west. In 1994, three GPR lines were run at the Seaside Golf Course, along a portion of the first fairway (Jol and others, 1996). All GPR lines were done at one meter step intervals and the reflection mode was set at 400 volts. 


\section{Results}

In the following results section, the tsunami deposit investigations are described for the corresponding tributaries in the following order: the Necanicum River, Neacoxie Creek, drainage to east of Neacoxie Creek, Stanley Lake, and Neawanna Creek (Figure 6). All core logs, trenches, and observation locations are displayed in a series of large scale maps including topographic contours. Figure 6 is a small scale reference figure for the larger-scale maps. Observation locations and descriptions are found in Appendix A. Appendix B contains all gouge core locations and descriptions. The gouge core field logs are contained within Appendix C. All radiocarbon dates including those from Darienzo and the beta identification numbers are in Appendix D. All grid core descriptions and locations and logs are found in Appendix E and F, respectively. Ground penetrating radar profiles of Seaside High School and Seaside golf course are presented as plates in the back pocket.

Both the 1964 and the prehistoric events contain tsunami-deposited sand layers (TSL). Historic (1964) TSL are identified by their shallow depth from surface, clean, quartz-rich sand, and typically sharp lower contacts. No subsidence occurred at Seaside because of the distal origin of the 1964 earthquake. Therefore, the 1964 sand layer should be found within a continuous lithologic unit, such as a mud or peaty deposit. This runup event was observed to have produced sand deposits at various known localities, therefore these sand layers will be referred to as the 1964 event. 


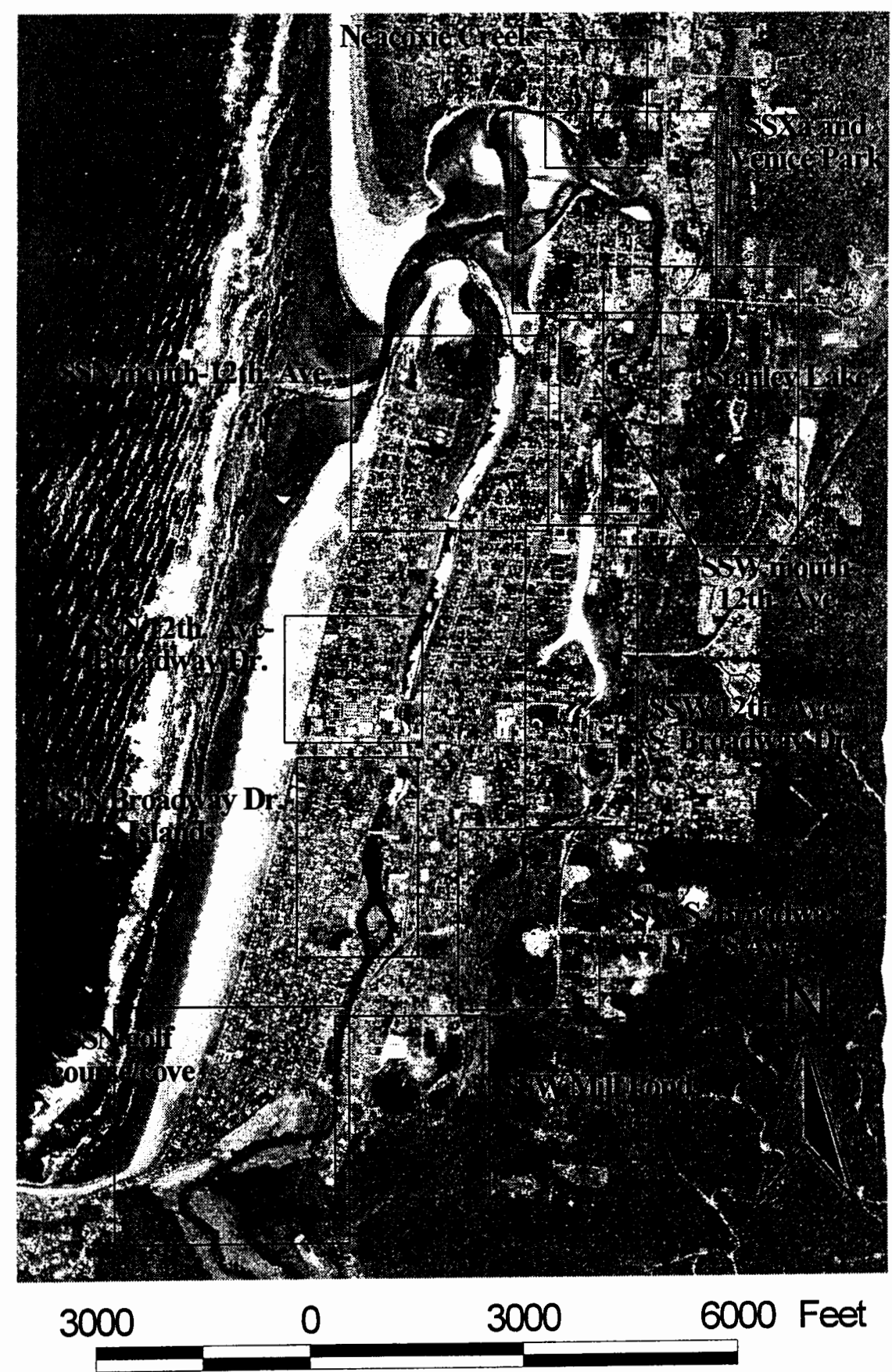

Figure 6. Coastal wetlands of Seaside studied for historic and prehistoric tsunami evidence. Boxes indicate large scale maps referred to in text. $\mathrm{SSN}=$ Necanicum River, $\mathrm{SSW}=$ Neawanna Creek, $\mathrm{SSXa}=$ Drainage to the east of Neacoxie Creek. 
The prehistoric tsunami-deposited sand layers (TSL) are located between underlying muddy peats and overlying rooted muds. This combination describes the sequence of events which are believed to occur following a megathrust earthquake: subsidence, tsunami inundation, and slow rebuilding of a colonizing (low) marsh to a very high marsh or forest setting. Some sandy layers at peat-mud contacts do not contain the correct subsidence stratigraphy or contact relations, so these sand layers might not be interpreted as tsunami deposits. These sands are referred to as sand capping layers (SCL). Further interpretations of TSL and SCL are provided in context of regional distribution in the discussion section.

Necanicum River (SSN)

Location

The N-S trending Necanicum River is located in the western portion of Seaside between the Pacific Ocean and Neawanna Creek. This study area extends five kilometers through western Seaside to its mouth. The eastern boundary of the Necanicum River wetlands is composed of cobble ridges, while the western side is defined by cobble ridges and the prograding beach system. The cove/golf course area (Ave. $U$, west) covers the southern extent of the Necanicum River study area.

1964 Event

Observations

Bridges crossing the Necanicum River suffered the greatest damage from the 1964 tsunami runup, although areas along the river were also flooded and inundated by drift debris. Between the Necanicum River and Holladay Drive (to the NE of SSN) 
surge levels reached one foot above the dune/cobble ridge elevation of 6.1 and $5.9 \mathrm{~m}$ (20 and $19.5 \mathrm{ft}$.) (SSN 668 and 669), respectively. Just to the immediate northwest of the 12th Avenue bridge, SSN 667 had drift debris at $3.5 \mathrm{~m}(11.5+\mathrm{ft}$.$) . The 12th$ Avenue bridge crossing the Necanicum River indicated a surge level running just below

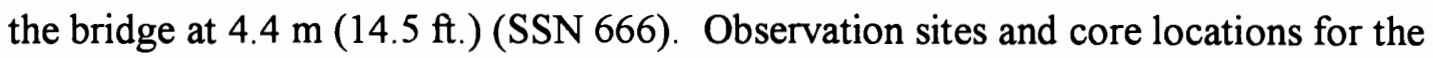
Necanicum River mouth to 12th Avenue bridge are shown in Figure 7. The 4th Avenue bridge, already condemned, was completely destroyed by the surge up the Necanicum River. Observations immediately north of the Broadway Drive bridge noted that the water levels were at or just above present elevation along the Necanicum River banks (SSN 661-665). The Broadway Drive turnaround on the promenade received logs jammed into the public restrooms (SSB 640), and surge splash marks were observed at SSB 641. Observations and core locations for 12th Avenue to Broadway Drive are shown in Figure 8. Site SSN 660 on the Avenue A bridge contained drift debris at $3.8 \mathrm{~m}(12.5 \mathrm{ft}$.). A $3.8 \mathrm{~m}$ water mark was noted at SSN 659, $3.4 \mathrm{~m}(11.0 \mathrm{ft}$.) at SSN 657 , and $3.6 \mathrm{~m}(11.8 \mathrm{ft}$.$) at SSN 656$ all of which are immediately to the northeast of Avenue G bridge (near the intersection of Ave. N and South Downing Dr.). Observation sites and core locations from Broadway Drive to the islands (Ave. S) are shown in Figure 9. Along the southern promenade, SSB 645 (near Ave. T) and SSB 646 (near the cove, west of West Point Rd.) had water levels at $4.9 \mathrm{~m}(16.0 \mathrm{ft}$.). At the Seaside Golf Course near the 9th hole green, two debris marks were noted at 2.9 and $2.3 \mathrm{~m}$ (9.5 and $7.5 \mathrm{ft}$.) (SSN 653). Finally, SSN 654 (near the 

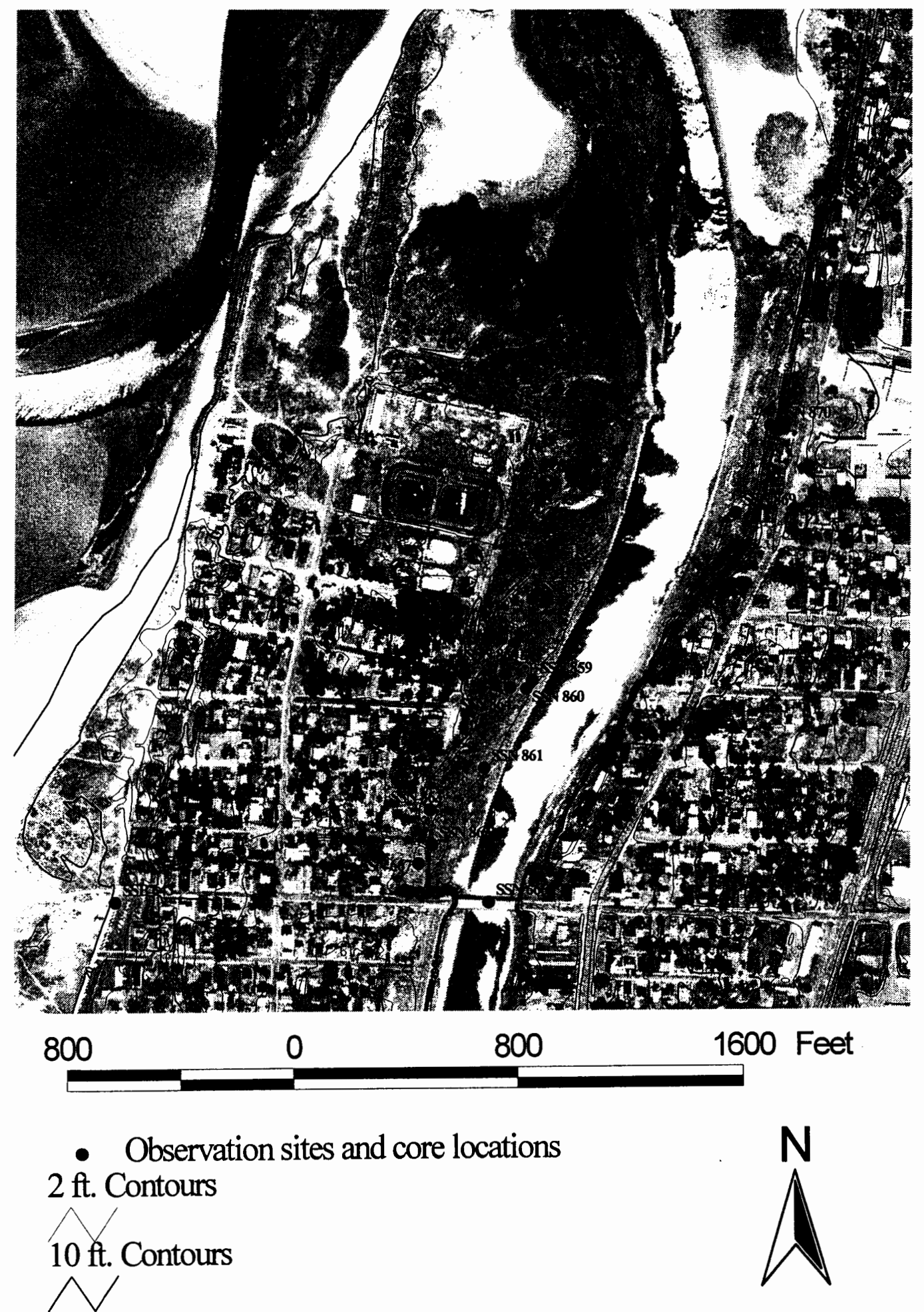

Figure 7. Observation sites and core locations from the Necanicum River mouth to 12th Ave. bridge. 


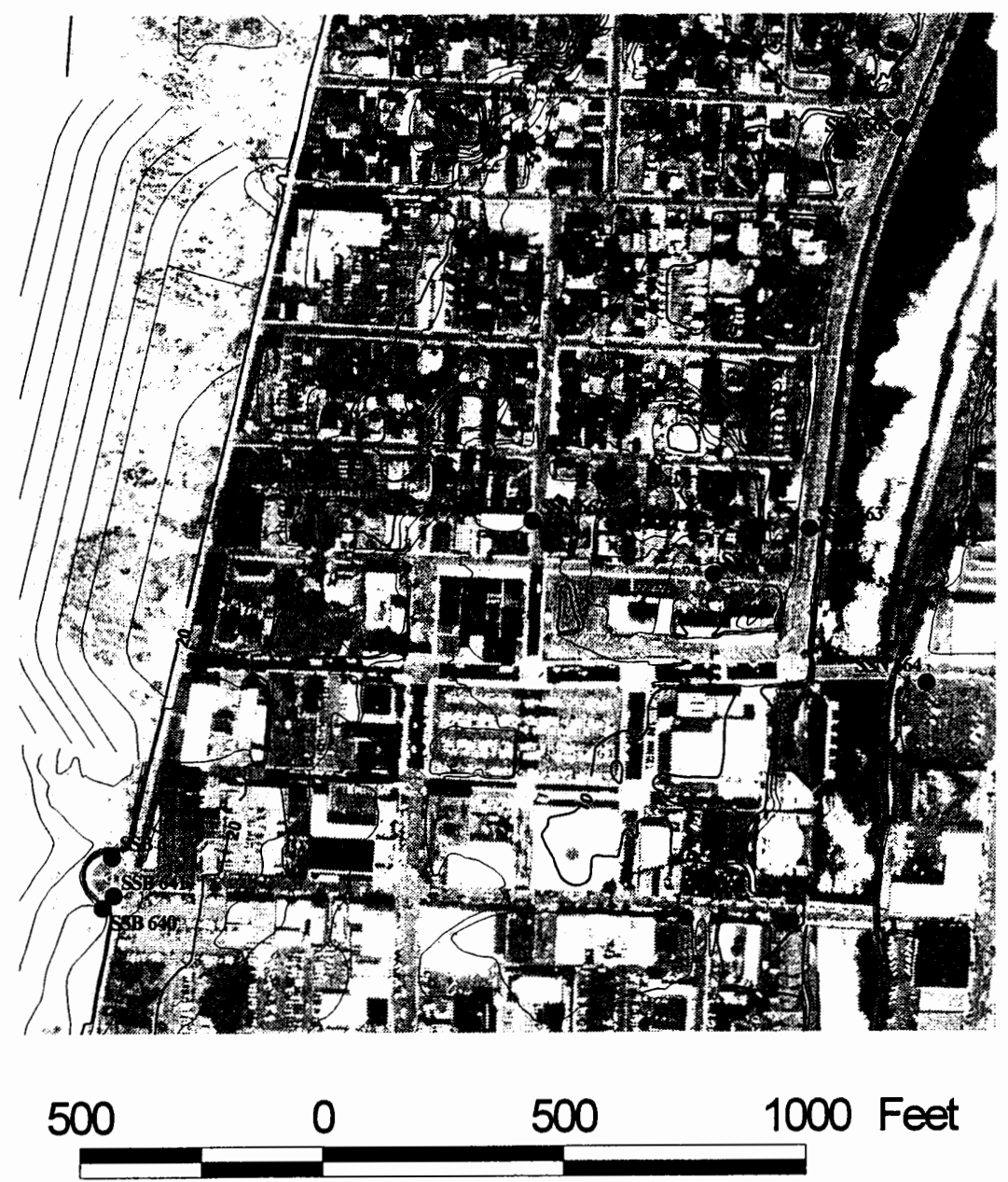

- Observation sites and core locations

$2 \mathrm{ft}$. Contours
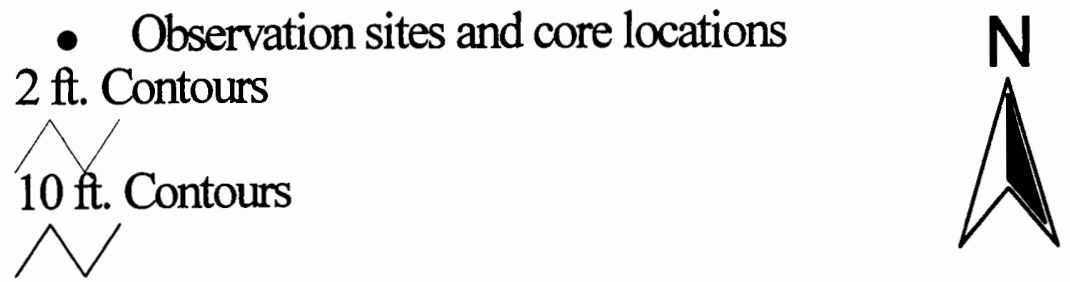

Figure 8. Observation sites and core locations for the Necanicum River from 12th Ave. to Broadway Dr. 


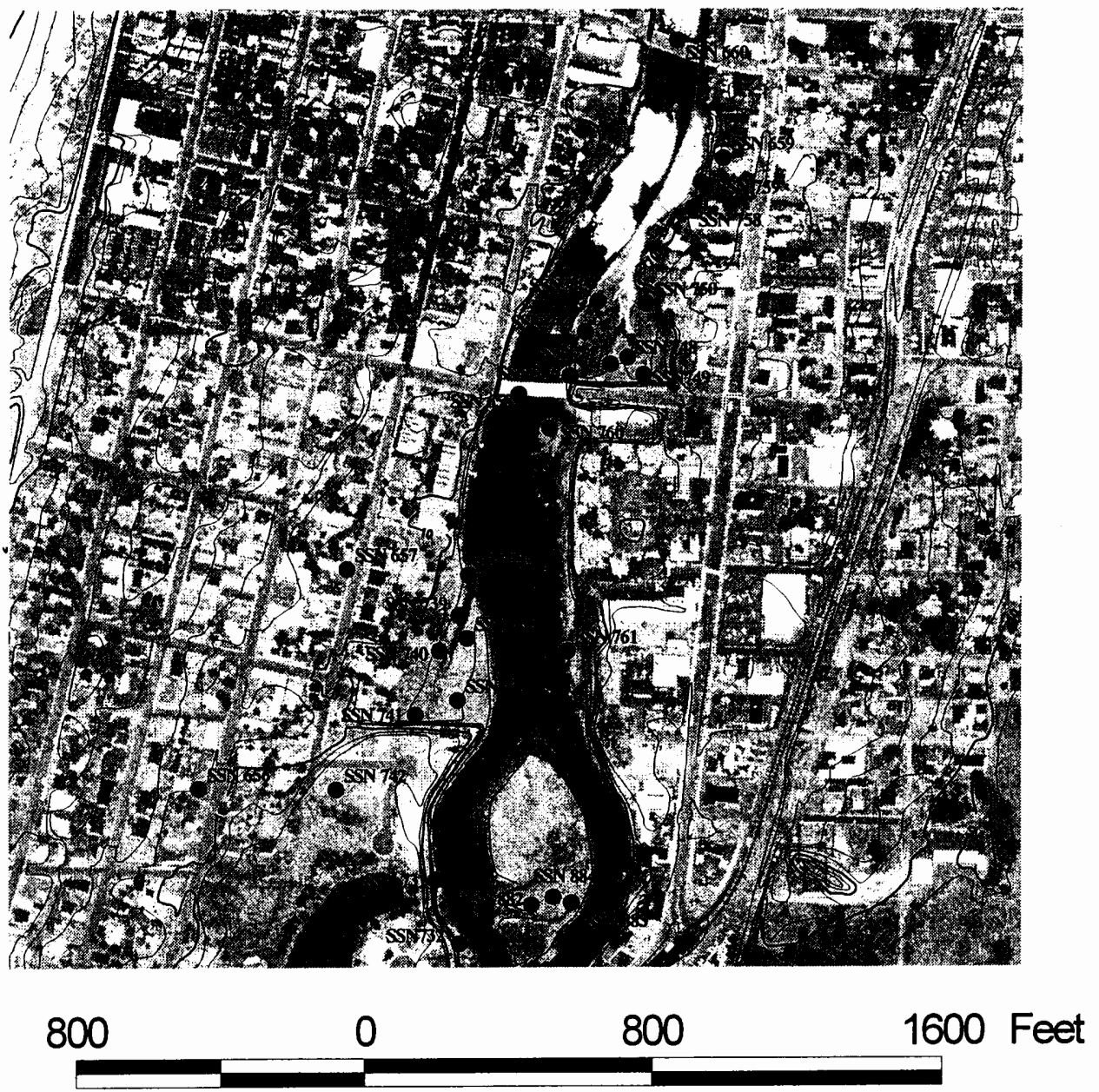

- Observation sites and core locations

$2 \mathrm{ft}$. Contours
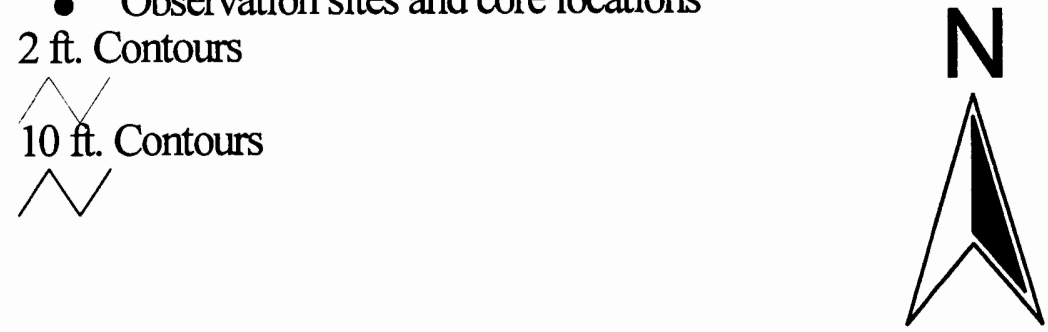

Figure 9. Observation sites and core locations for the Necanicum River from Broadway Dr. to the islands (Ave. S). 
8th hole green) indicated debris at $2.9 \mathrm{~m}$ (9.5 ft.). Observation sites and core locations from the islands (Ave. S) to the Seaside golf course (Ave. U) including the cove are shown in Figure 10.

\section{Gouge Coring}

The 37 cores taken throughout the Necanicum River coastal wetlands will be described from the northern extent to the southernmost extent. Maximum penetration of $300 \mathrm{~cm}$ occurred at SSN 827 near the cove, but along the river $240 \mathrm{~cm}$ was the maximum depth reached. The average penetration was $100 \mathrm{~cm}$, although, cobble ridges or dense sand limited the core interval to shallower depths in some areas.

\section{Necanicum River mouth to 12th Avenue (Figure 7)}

Near the mouth of the Necanicum River, SSN 871, 870, and 863 document the 1964 event within the northwestern bank (Figure 11). These cores contain a fairly thick clean sand (10-20 cm thick) in sharp lower contact with the underlying thin layer of peat or mud at a depth of $27-30 \mathrm{~cm}$. This thick layer represents deposition from the 1964 tsunami.

Broadway Drive to the islands (Ave. S) (Figure 9)

Core sites SSN 759,750,747, and 737 all contain thinner 1964 sand layers than to the north. These cores have a thin sand layer (averaging $5 \mathrm{~cm}$ thick) in the 10 to $20 \mathrm{~cm}$ depth interval within a muddy peat or peaty mud (Figure 12). The southern extent of the Necanicum River indicates a tsunami sand layer (Figure 13) thinning with increasing distance upriver. Sites SSN 731, 882, and 884 are located relatively close to each other. Site SSN 731 does not contain shallow sand laminations or layers, indicating no 


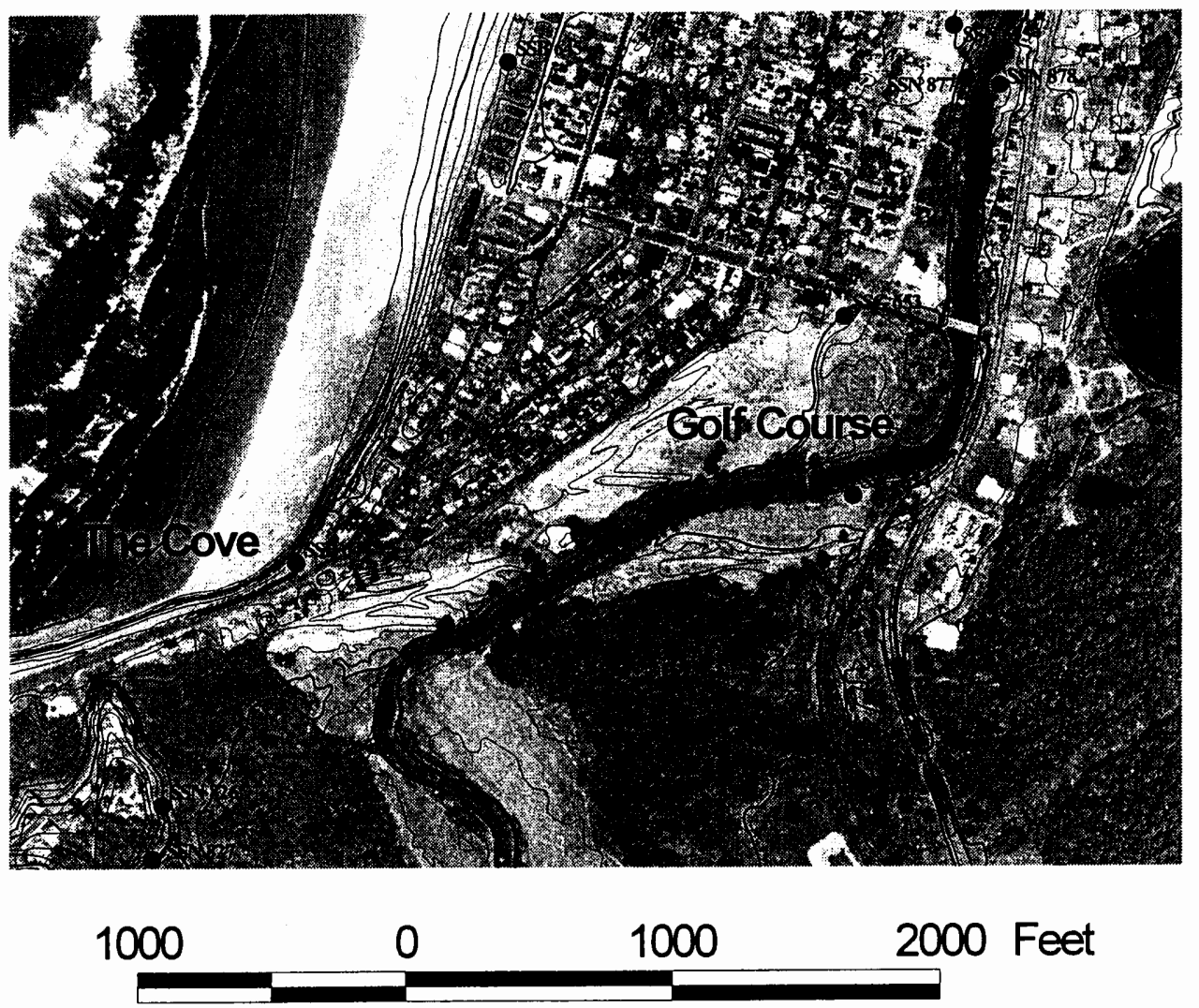

- Observation sites and core locations

$2 \mathrm{ft}$. Contours
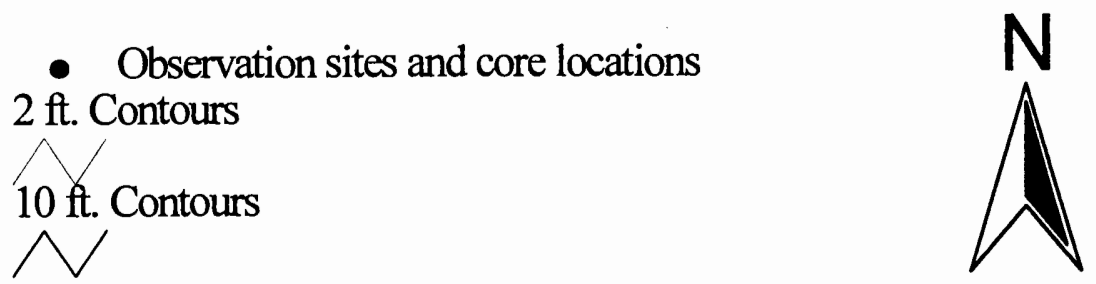

Figure 10. Observation sites and core locations for the Necanicum River from Necanicum Islands (Ave. S) to the cove/golf course (Ave. U). 


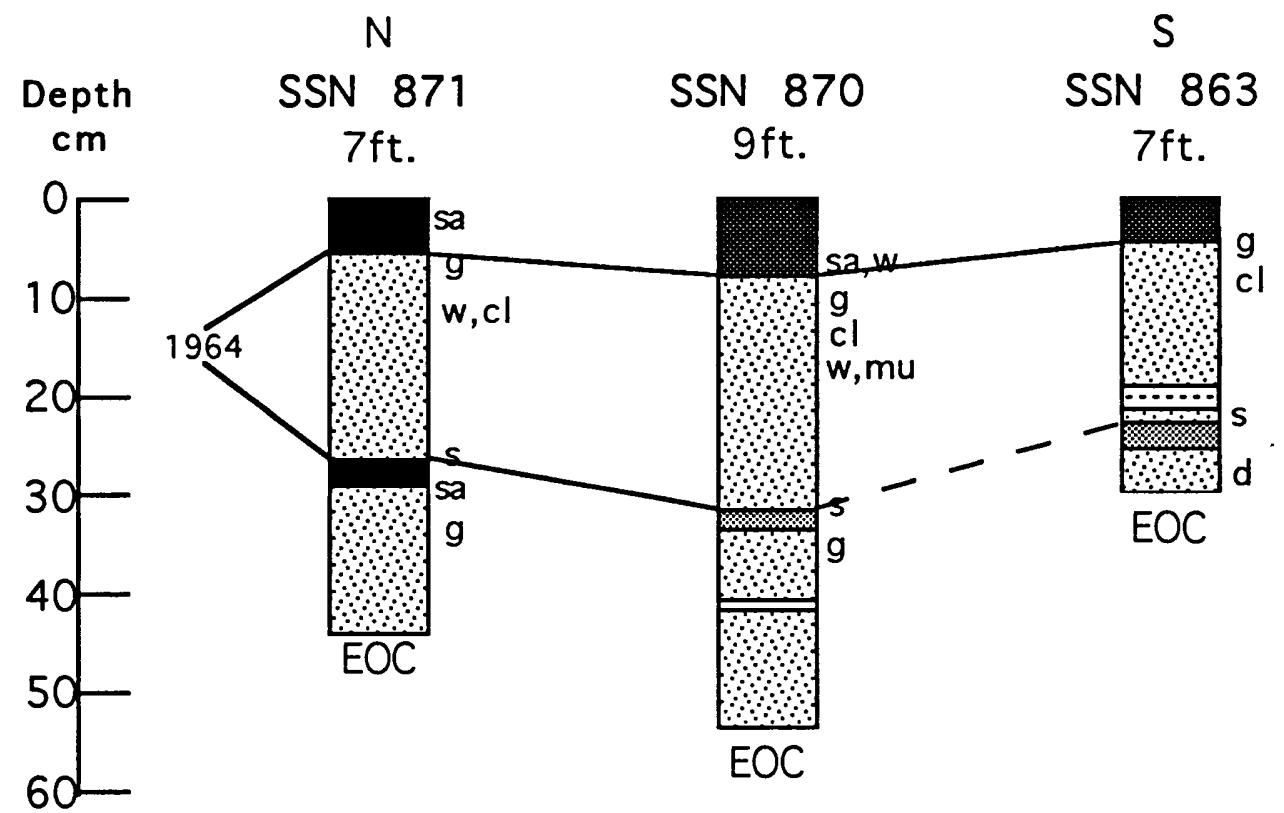

Figure 11. Northern Necanicum River cores SSN 871, 870, 863; showing a 1964 sand deposit. Gouge cores include present marsh surface elevation in feet. 


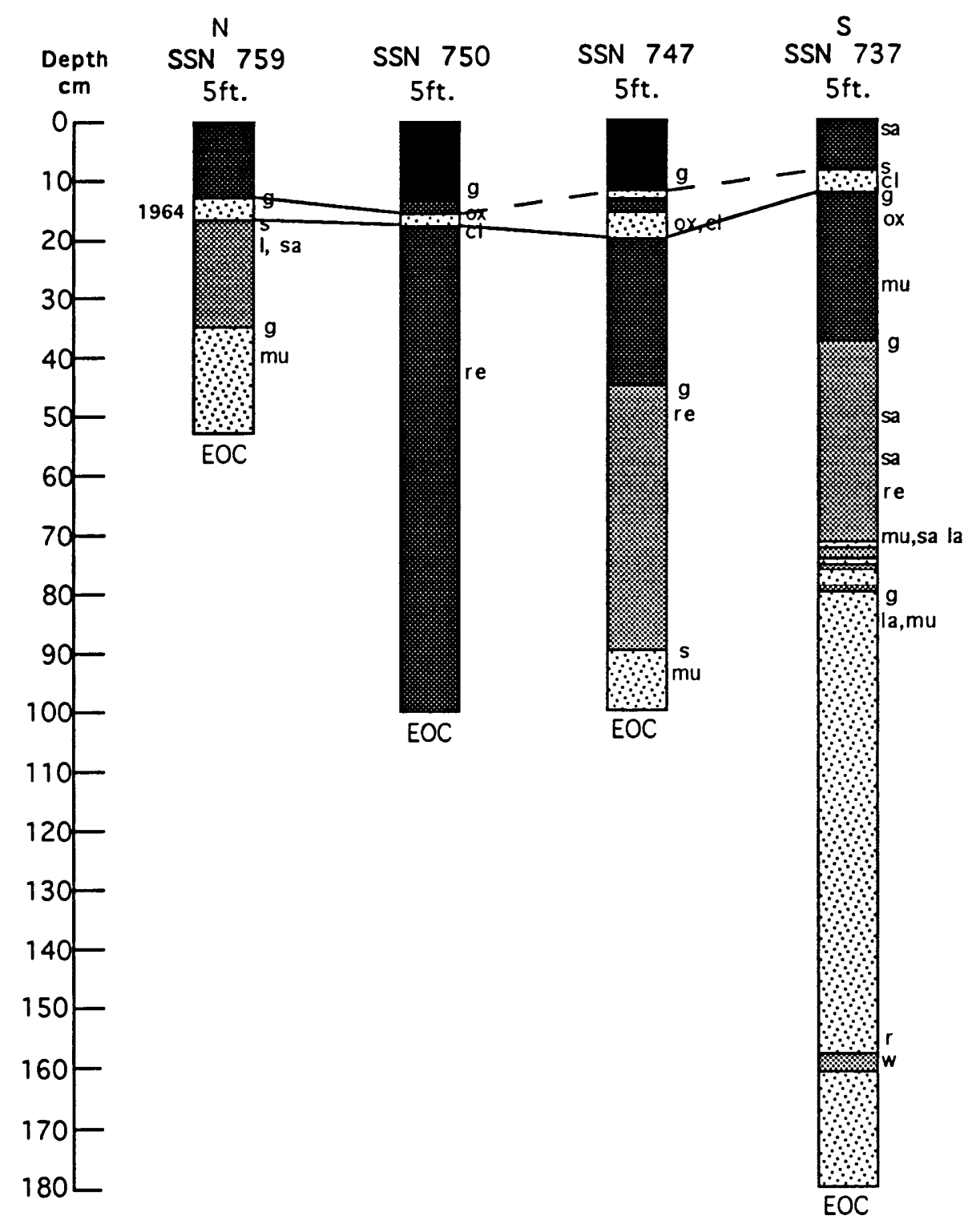

Figure 12. Central Necanicum River cores SSN 759, 750, 747, 737; showing a 1964 deposit. 


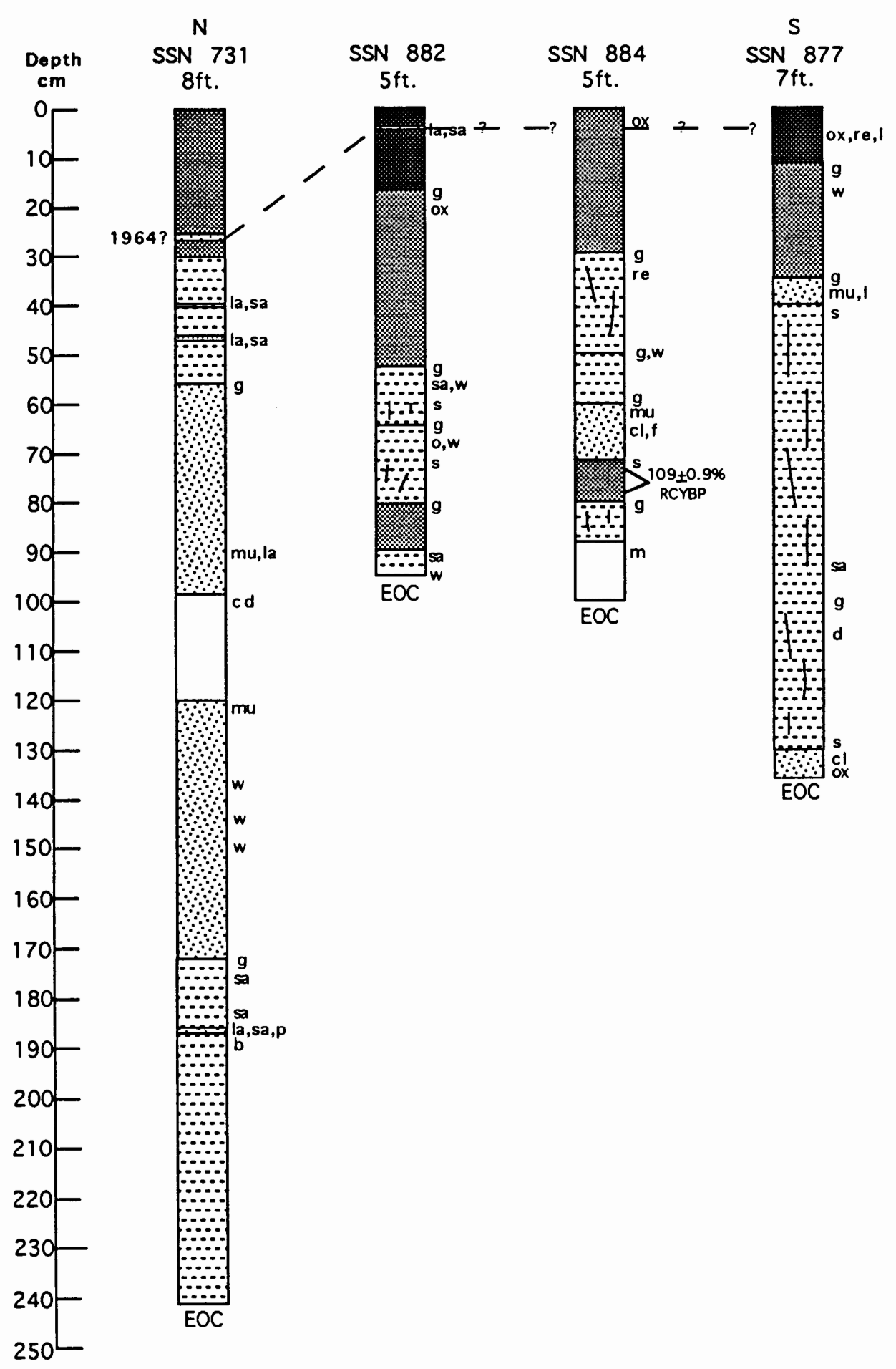

Figure 13. Southern Necanicum River cores SSN 731, 882, 884, and 877; showing the thinning of the 1964 deposit. 
sand deposition from the 1964 event. However, SSN 882 on the central Necanicum River islands contains a sand lamination at five centimeters depth, which could very well have been deposited by the 1964 tsunami.

The islands (Ave. S) to Seaside golf course (Figure 10)

Immediately south of the old Hospital near Avenue S, no sand layers or laminations occur at shallow depths in SSN 877 (Figure 13). The stratigraphies of these cores do not match very well, but it is evident that further upriver, the shallow 1964 sand layer completely disappears.

\section{Trenching}

Three trenches, 3A-C, were taken at sites along the Necanicum River. The northernmost trench, 3A, is located at gouge core site SSN 864. This trench contains a similar stratigraphy to the core log of SSN 864 (Figure 14). A clean sand layer with a lower sharp contact with a rooted mud is located between the $5-10 \mathrm{~cm}$ interval. The sand layer is an example of the 1964 tsunami sand deposit. Trench 3B is centrally located on the Necanicum River at gouge core site SSN 748. Again, both the trench and core log contain similar stratigraphies (Figure 15). Site SSN 748 indicates two thin ( $2 \mathrm{~cm}$ thick) clean sand layers at ten and $18 \mathrm{~cm}$, where as the trench in both west and southern faces indicate one continuous sand layer at $9-13 \mathrm{~cm}$. The two sand layers observed within the core might represent two surges of the 1964 tsunami. Finally, to the south, trench $3 \mathrm{C}$ is located at SSN 732 (Figure 16). The stratigraphy between the core $\log$ and the trench differ. Trench $3 \mathrm{C}$ does not contain any shallow sand layers and 
Trench SSN 3A, West Face

$7 \mathrm{ft}$.

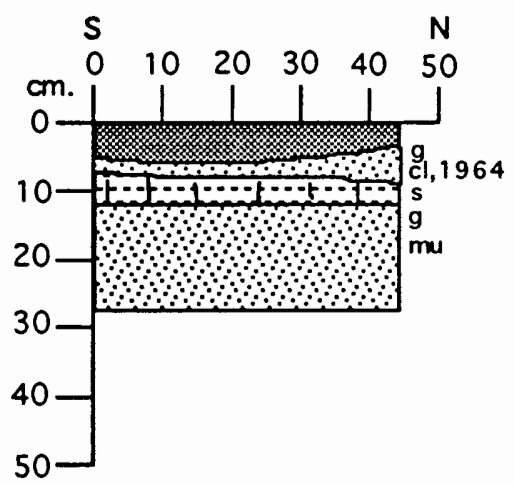

0-4 cm, peaty mud, bwer gradational contact.

4-9 cm, sand, clean, sharp lower contact, 1964.

9-12 cm, rooted mud, lower gradational contact.
Trench SSN 3A, South Face

$7 \mathrm{ft}$.

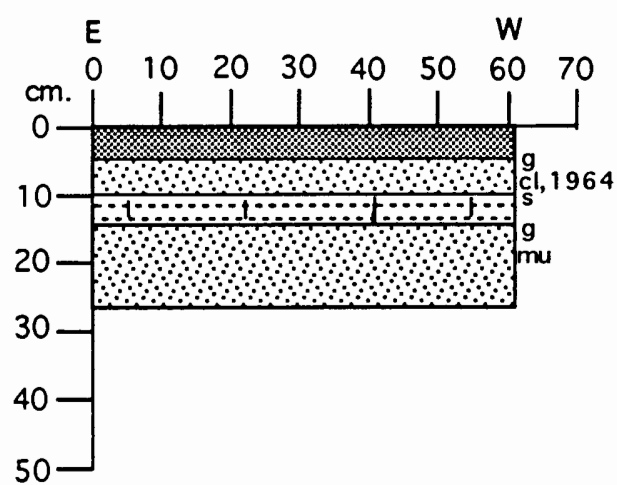

$0-5 \mathrm{~cm}$, peaty mud, lower gradational contact.

5-10 cm, sand, clean, sharp lower contact, 1964.

$10-14 \mathrm{~cm}$, rooted mud, lower gradational contact.

14-27 cm, sand, muddy.

12-27 cm, sand, muddy.

Figure 14. Northern Necanicum River trench 3A (core site SSN 864).

Trench SSN 3B, West Face

$5 \mathrm{ft}$.

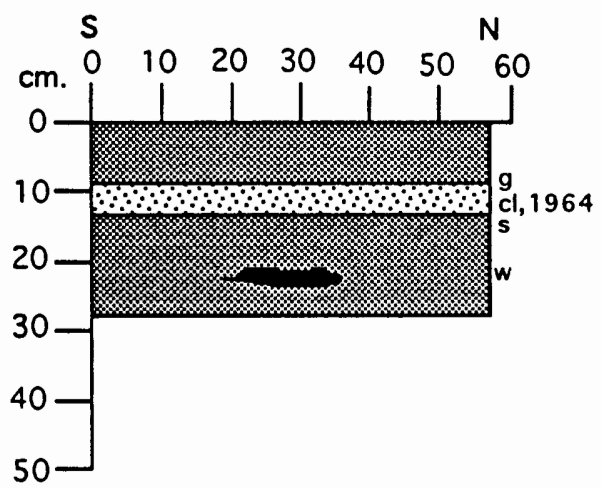

$0.9 \mathrm{~cm}$, peaty mud, gradational lower contact.

9-13 cm, sand, clean, sharp lower contact, 1964.

13-27 cm, peaty mud, detrital wood fragment@21-24 cm.
Trench SSN 3B, South Face

$5 \mathrm{ft}$.

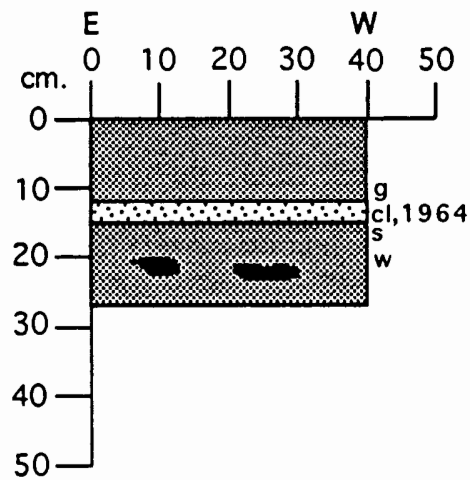

$0-12 \mathrm{~cm}$, peaty mud, gradational lower contact.

12-15 cm, sand, clean, sharp lower contact, 1964.

$15-27 \mathrm{~cm}$, peaty mud, detrital wood fragments@ $20-25 \mathrm{~cm}$.

Figure 15. Central Necanicum River trench 3B (core site SSN 748). 
Trench SSN 3C, West Face $5 \mathrm{ft}$.

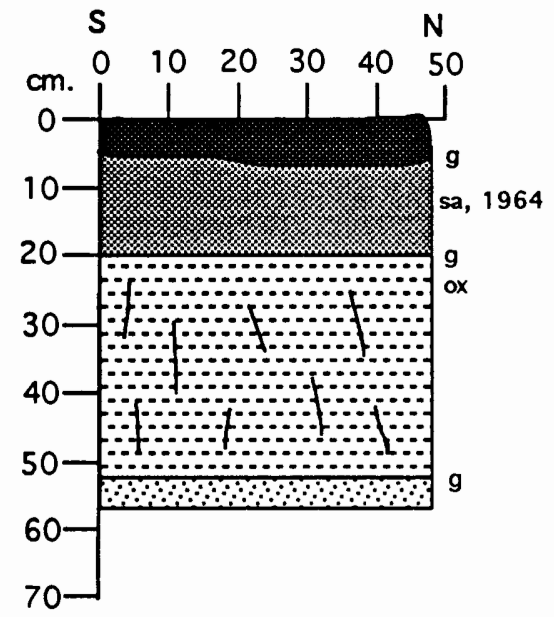

0-7 cm, muddy peat, hint of sand @ $12 \mathrm{~cm}$, lower gradational contact (1964).

$7-20 \mathrm{~cm}$, peaty mud, gradational lower contact.

20-52 cm, rooted mud, oxidized, lower gradational contact.

$52-56 \mathrm{~cm}$, sand.
Trench SSN 3C, North Face $5 \mathrm{ft}$.

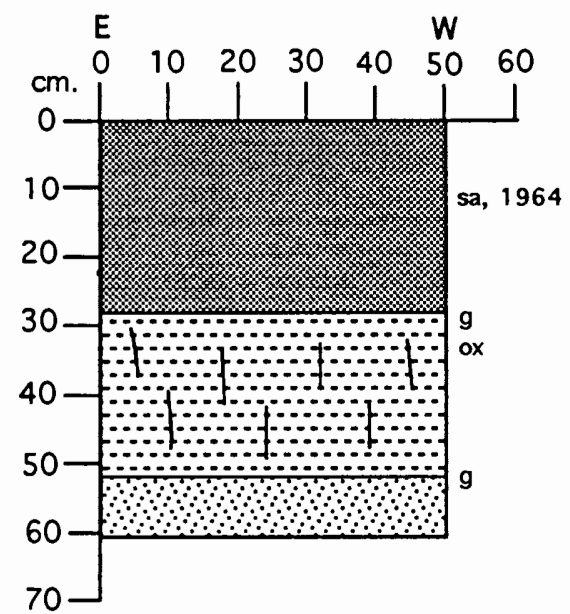

$0-28 \mathrm{~cm}$, peaty mud, hint of sand @ $13 \mathrm{~cm}$, gradational lower contact (1964).

28-52 cm, rooted mud, oxidized, lower gradational contact.

$52-60 \mathrm{~cm}$, sand.

Figure 16. Southern Necanicum River trench 3C (core site SSN 732). 
does have a peaty mud overlying a rooted mud. Site SSN 732 has a peaty mud with three isolated sand layers at $38-50 \mathrm{~cm}$, however no shallow sand layers are evident. Trench $3 \mathrm{C}$ contains a sandy section within the peaty mud at $13 \mathrm{~cm}$, a possible indicator of the 1964 tsunami.

\section{Diatom Analysis}

A diatom sample taken from SSN 827 at $288 \mathrm{~cm}$ (Figure 10) would determine whether there was any marine influence within a continuous core of muddy peat at this site. This sample was difficult to evaluate due to a lack of sufficient diatom valves for counting. No definite influence of marine or freshwater, based on diatoms, could be determined for this sample.

\section{Radiocarbon Samples}

A possible buried horizon was identified on the island of the central Necanicum River at SSN 884. A peat sample obtained from $71-80 \mathrm{~cm}$ yielded $109.0 \pm 0.9 \%$ RCYBP as an age. This young date does not argue for a prehistoric buried interval from the $1700 \mathrm{AD}$ Cascadia earthquake within the Necanicum River wetlands.

\section{Summary}

The Necanicum River contains many water level and runup observations from the 1964 tsunami event. Sites reported to have been impacted by flooding, debris and/or sand deposits were examined by gouge core or trenches to establish the resulting stratigraphic records from the observed runup. There is strong evidence for the 1964 tsunami deposits throughout the north to north-central wetlands of the Necanicum River. Three general trends are evident in the Necanicum River wetlands for the 1964 
event: 1) shallow sand layer thickness decreases to the south, and the deposits eventually become non-existent in the area near the old hospital (Ave. S), 2) some deposits contain more than one sand layer or an interfingering of sand and mud shallow in the cores, indicating more than one surge depositing the sand, and 3) as distance from the mouth of the Necanicum River increases, the lithology of the sand layers reflects the local sand supply, the sand being more angular and containing less quartz and more rock fragments.

\section{Prehistoric Events}

No laterally-continuous buried peat horizons were observed in the Necanicum River wetlands. The only possible buried horizon occurs at SSN 884, however, due to the young radiocarbon date $(109.0 \pm 0.9 \% \mathrm{RCYBP})$ at $71-80 \mathrm{~cm}$ within this core no further analysis of this site was undertaken.

\section{Neacoxie Creek (SSX)}

\section{Location}

Neacoxie Creek, to the north of Seaside, runs N-S and its mouth opens into the Necanicum estuary. A $7.3 \mathrm{~m}$ (24 ft.) tree and grass vegetated sand dune containing an underlying cobble layer bounds the eastern side of Neacoxie Creek. The western boundary of Neacoxie Creek is confined by low lying sand dunes. G Street bridge in Gearhart bounds the northern extent of the Neacoxie Creek study area. Tides influence the water level of the creek, throughout its length in the study area. 
1964 Event

\section{Observations}

Observations made by eye-witnesses in 1964 indicated that G Street (road fill over culvert) substantially slowed the surge up Neawanna Creek (Figure 17). Driftwood and logs jammed the culvert, and some logs and sand were thrown onto the G Street pavement (SSX 650). Home owners reported sand deposits along the east bank and G Street crossing the Neacoxie Creek (T. Horning, personal communication, 1996). Large diameter drift logs were washed up against and on top of G Street. Homes on the western bank of Neacoxie Creek experienced flooding, marking a water level at $3.8 \mathrm{~m}(12.5 \mathrm{ft}$.) (SSX 648). In one case, a woodshed moved westward roughly $24.4 \mathrm{~m}(80 \mathrm{ft}).(\mathrm{SSX} 652)$.

\section{Gouge Coring}

In the marsh surrounding Neacoxie Creek, ten gouge cores were taken (Figure 17). The average core depth was $65 \mathrm{~cm}$, and no cores penetrated deeper than one meter. Extremely dense, thick sands underlie the upper muddy sand or peaty mud deposits on either side of Neacoxie Creek. Subsidence horizons or sand layers indicative of prehistoric deposits were not present in the Neacoxie Creek wetlands. However, shallow in the section, clean, fine-grained, occasionally fining upward sand layers were identified, indicating sand deposited from the 1964 tsunami.

On the east bank of Neacoxie Creek, SSX 754 and 770 show a thick, clean sand becoming muddy down section (Figure 18). The SSX 754 sand layer has a sharp lower 


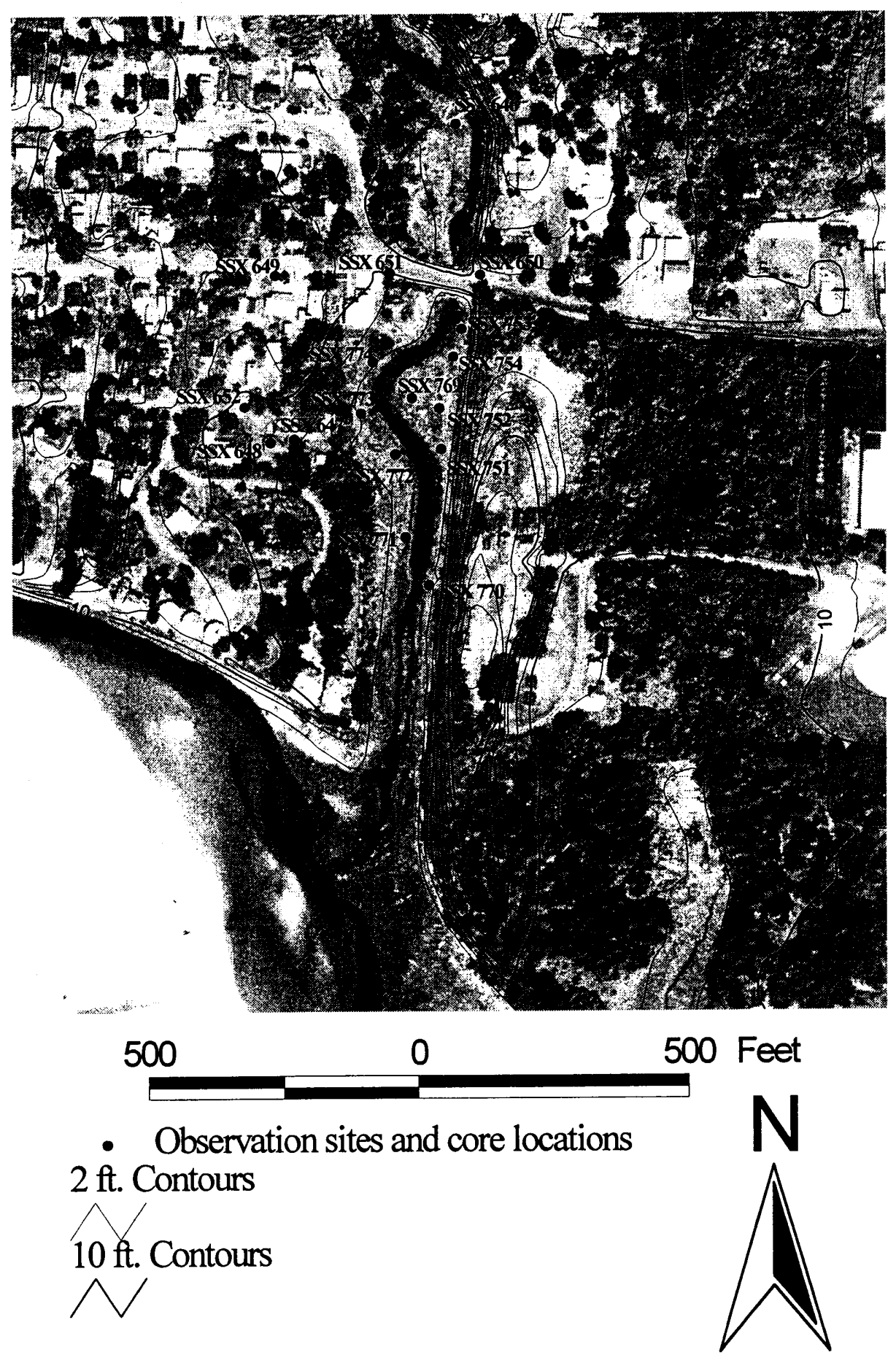

Figure 17. Neacoxie Creek observation sites and core locations. 


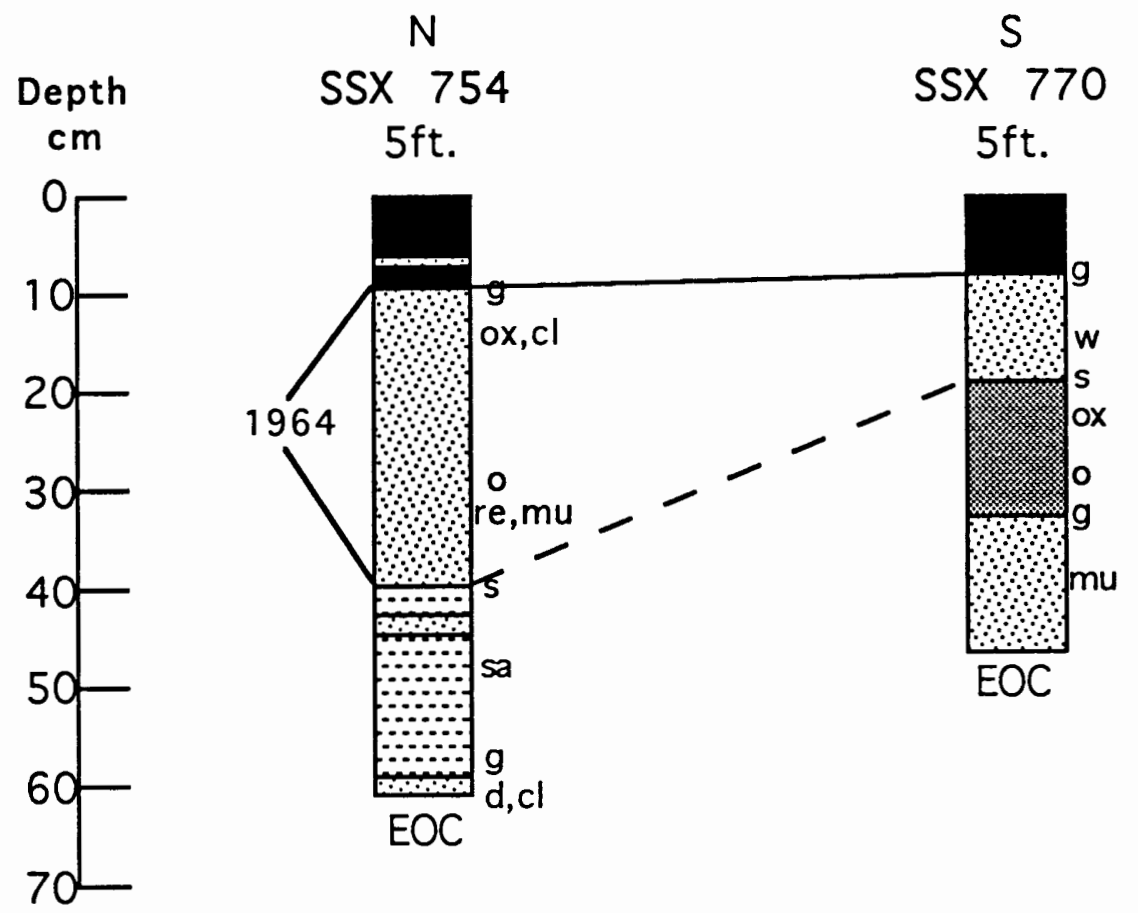

Figure 18. Neacoxie Creek east bank cores SSX 754 and 770. 
contact with rooted mud from $9-40 \mathrm{~cm}$ depth, and an overlying thinner sand layer at seven centimeters. To the south, SSX 770 shows ten centimeter thick sand layers. The west bank of Neacoxie Creek (Figure 19) comprises gouge cores SSX 772-774, which all have clean sand laminations shallow in the section at $10-20 \mathrm{~cm}$ and thick sandy to muddy sand layers deep in the section. However, to the south, SSX 771 contains a thicker, clean sand layer from $9-18 \mathrm{~cm}$ with a sharp lower contact.

\section{Grid coring}

To obtain a clearer understanding of the tsunami depositional processes at Neacoxie Creek in 1964, 28 cores were incorporated in a $25 \mathrm{~m}$ grid with the main grid lines running roughly N-S (see methods). Logged grid core locations for Neacoxie Creek are found in Figure 20. Due to urbanization or meanders of the Neacoxie Creek channel, some grid sites could not be cored. Maximum gouge core penetration was $100 \mathrm{~cm}$ at SSX XVIII, and the average core depth reached was $72 \mathrm{~cm}$.

Shallow 1964 sand deposits of the Neacoxie Creek east bank differed from those of the west bank. The east bank contains thick sand deposits, shallow in the section, at the north portion of the grid near the G Street. This is evident in grid core SSX III, having a $18 \mathrm{~cm}$ thick sand layer with a sharp lower contact. These thick deposits taper in the central reaches, evident in grid cores VII-X. Grid cores VII-X have shallow sand layers from 3 to $13 \mathrm{~cm}$ in thickness with mud laminations. Grid core XI, to the south of VII-X, thickens toward the mouth of Neacoxie Creek. This sand deposit ranges from 3 to $31 \mathrm{~cm}$ from the present surface, and it has a sharp lower contact with 


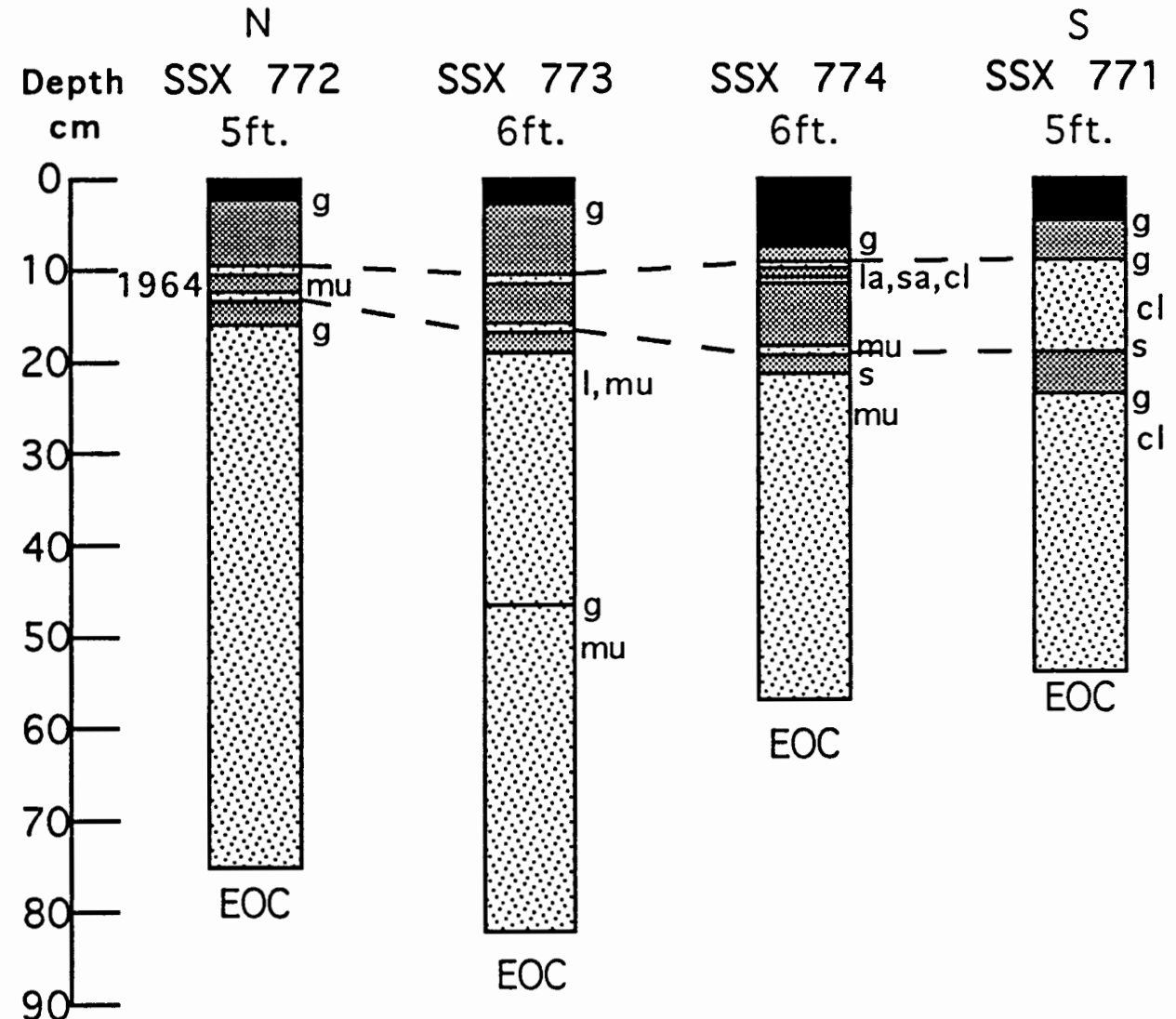

Figure 19. Neacoxie Creek west bank cores SSX 771-774. 


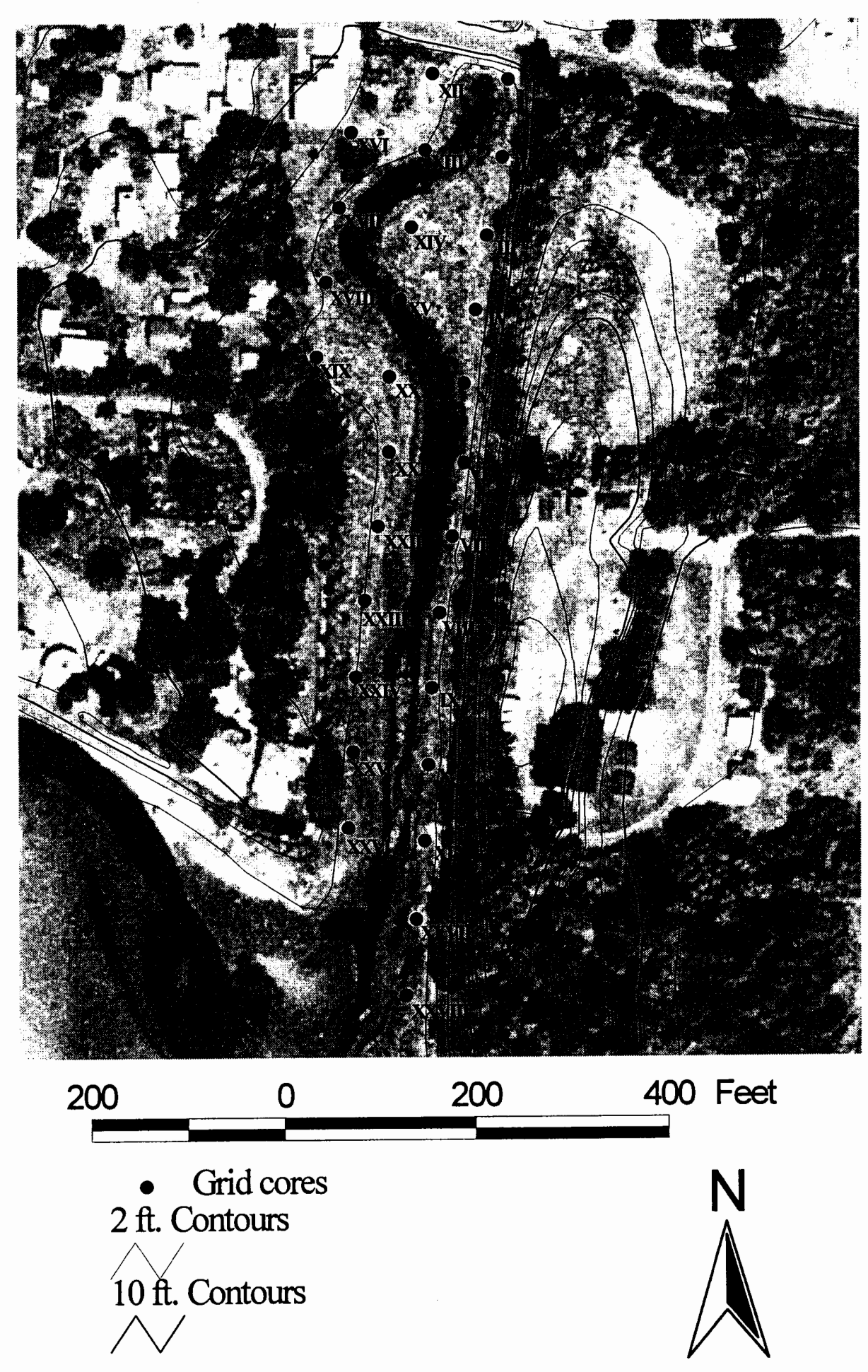


a peaty mud. However, XXVII and XXVIII grid cores south of XI show another thinning trend. Sand thickness varies from $12 \mathrm{~cm}$ in XXVII to six centimeters in XXVIII. Figure 21 shows the N-S grid section discussed for the Neacoxie Creek east bank. Grid cores on the western bank of Neacoxie Creek show a differing stratigraphy from the eastern bank. Cores to the north contain sand with interlayers of mud (about $1 \mathrm{~cm}$ thickness). In Grid core XIII, five mud interlayers of roughly one centimeter in thickness are contained within a sand layer ranging from 7 to $25 \mathrm{~cm}$ from present surface. Cores XX-XXII show interlayers of sand, mud and peaty mud ranging from about $8-50 \mathrm{~cm}$. Peaty mud dominates the upper section along with some sand layers in grid core $\mathrm{XX}$. Sand and mud layers dominate the upper section of XXI, and this core contains a combination of sand and peaty mud layers. The southernmost two cores, XXV and XXVI, contain sand layers very shallow in the section (from 10-20 cm) with confining muddy peat above and below the sand. Figure 22 shows the N-S section of the Neacoxie Creek western bank stratigraphy.

East-west cross-sections across the creek channel show differences in 1964 sand thickness from one bank to the other. To the north, cores III and XVIII are very similar in stratigraphy, especially in the upper $30 \mathrm{~cm}$ of section (Figure 23). Central Neacoxie Creek shows similar stratigraphy between east and west banks. Cores VI and XXI both have a shallow, clean sand layer with a lower sharp contact with a peaty mud, however, XXI contains more interlayering of mud and sand (Figure 24). Finally, farther south, cores X and XXVI have similar stratigraphies as well (Figure 25). 


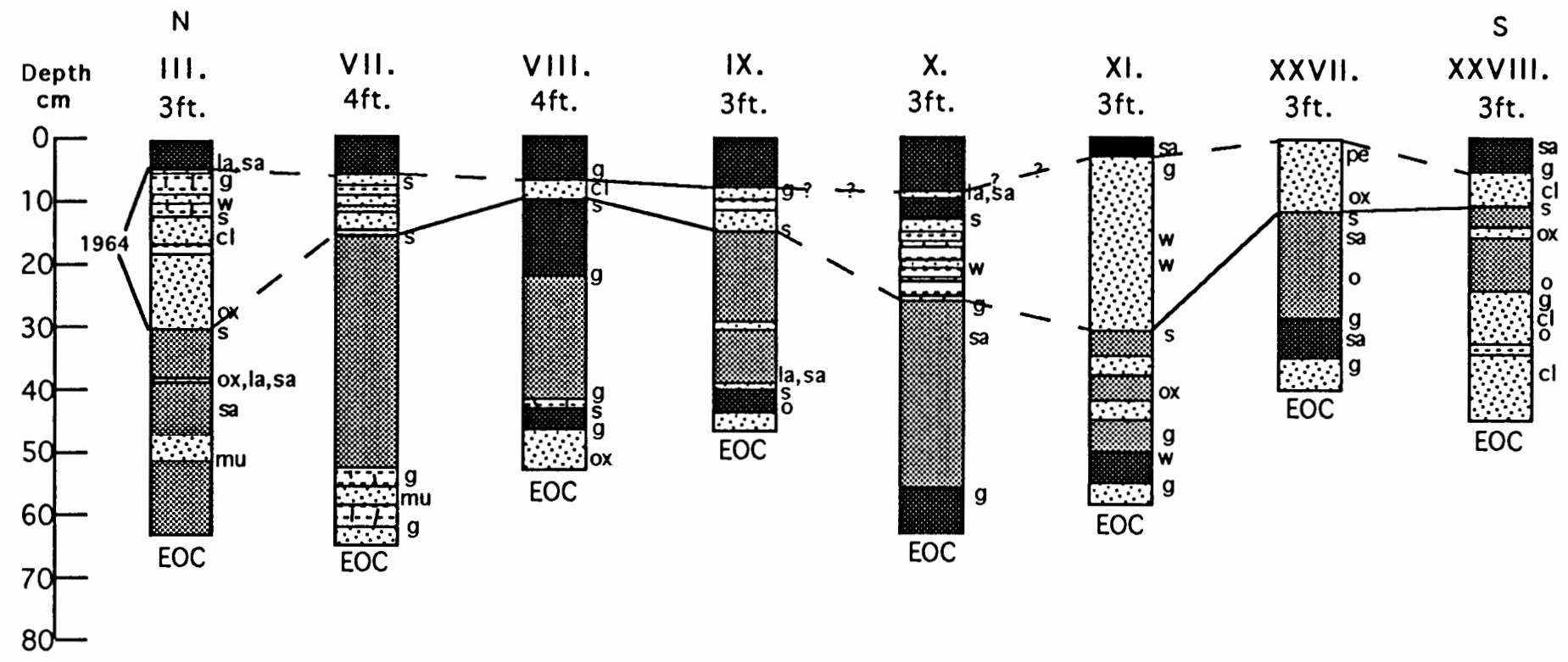

Figure 21. Neacoxie Creek east bank N-S grid cross-section (SSX III, VII, VIII, IX, X, IX, XXVII, and XXVIII). 


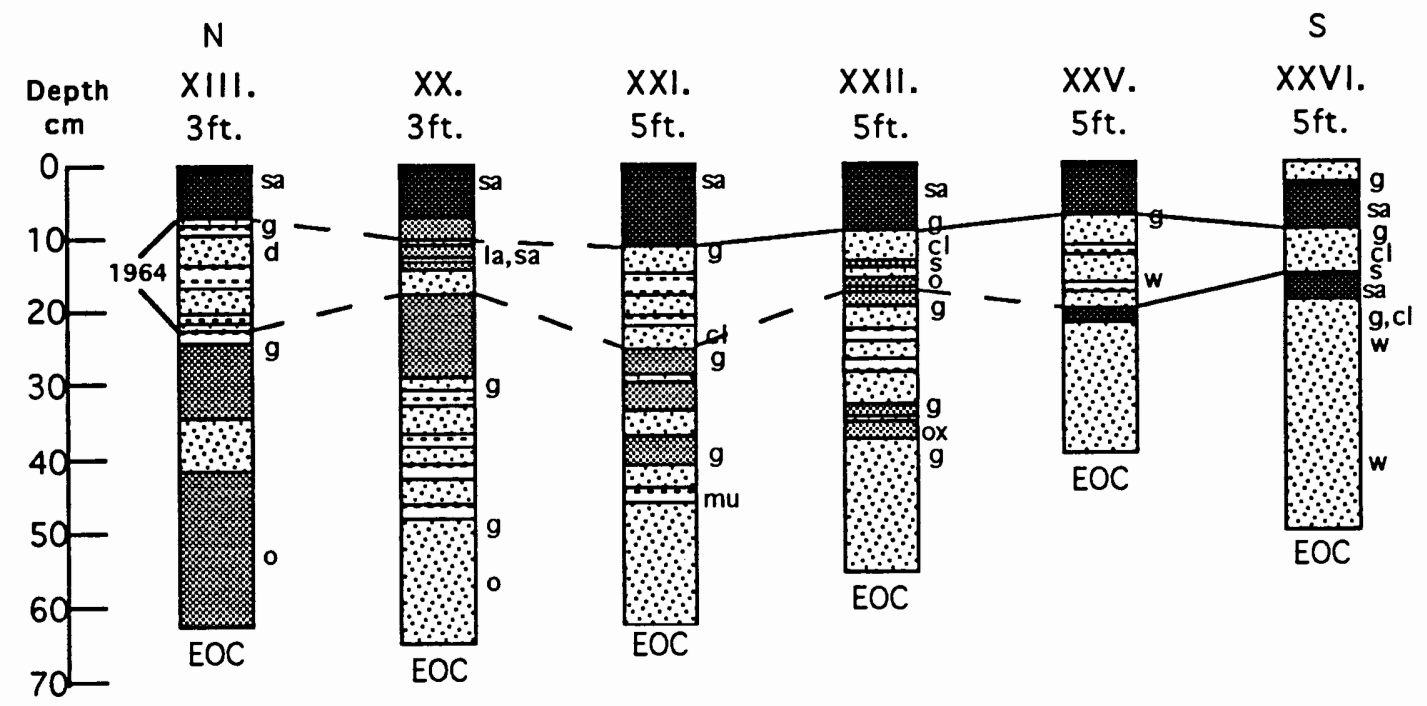

Figure 22. Neacoxie Creek west bank grid cores (SSX XIII, XX, XXI, XXII, XXV, XXVI)

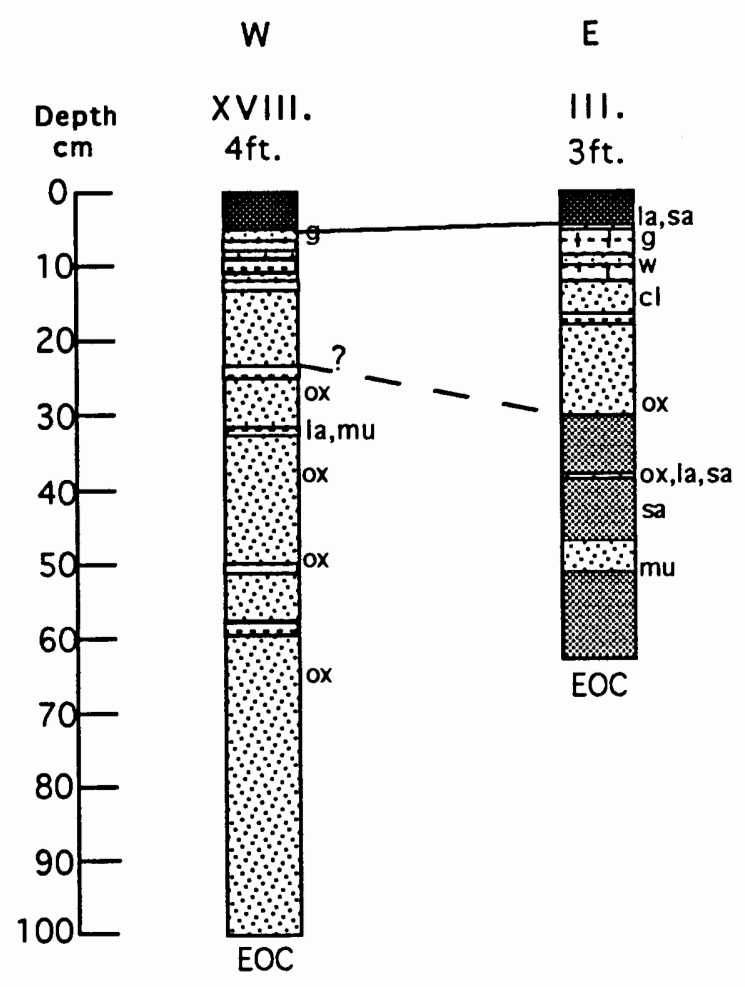

Figure 23. Neacoxie Creek E-W cross-sections, northern cores (SSX III and XVIII). 


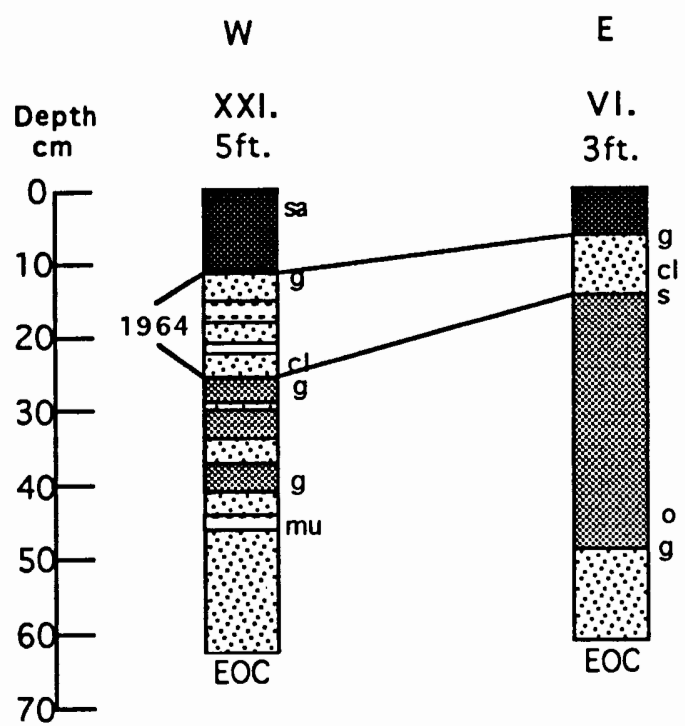

Figure 24. Neacoxie Creek E-W cross-section, central cores (SSX VI and XXI).

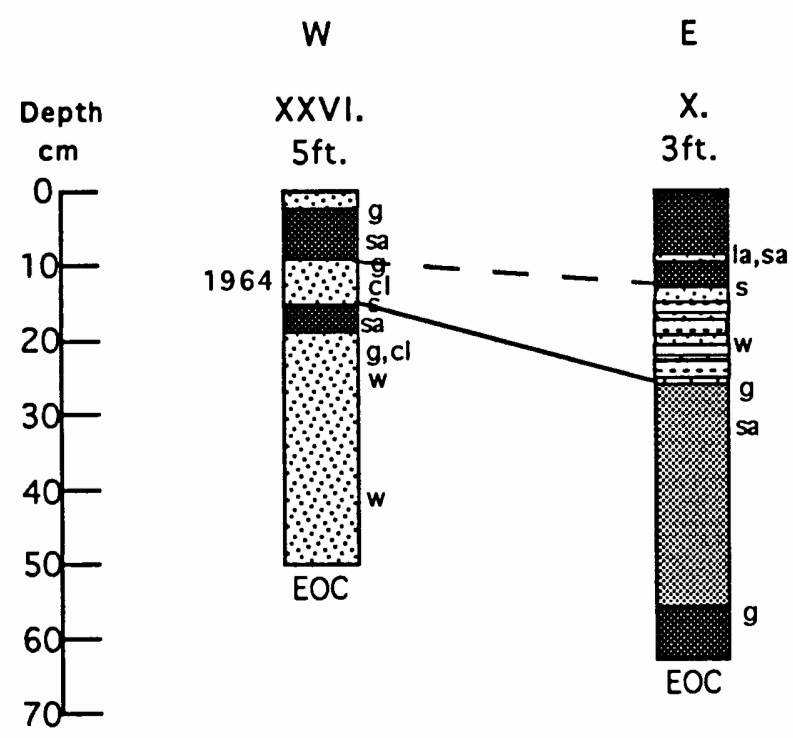

Figure 25. Neacoxie Creek E-W cross-section, southern cores (SSX X and XXVI). 
However, the eastern core (X) has more interlayers of sand and mud.

Two general trends are apparent from the close-spaced grid coring. Firstly, multiple surges are represented by thin mud layers separating the sand layers. For example, two mud layers are found within the sand deposits (SSX XXV, XXI, XIII, III, VII), yielding three apparent surge events. Grid site SSX III shows a thinning of sand layers from bottom (thickest) to top (thinnest). However, vertical trends in surgesand layer thickness are variable in other sites showing sand layer separation by mud laminations. The second general trend of the 1964 sand layer is that it thins from the mouth of Neacoxie Creek to the middle reaches of the N-S grid area, and it then thickens immediately south of G Street.

\section{Trenching}

Additional subsurface investigations, using trenching, completed the study of the 1964 tsunami deposition along the banks of Neacoxie Creek. Two trenches, SSX 2A and 2B, were dug along the east bank of Neacoxie Creek. The northern most trench, SSX 2A (Figure 26), is located at gouge core site SSX 754, and it shows a very shallow section of sand underlain by rooted mud and overlain by peaty mud. Total depth of the trench extends to $30 \mathrm{~cm}$. The upper sand layer, from $10-25 \mathrm{~cm}$, has a sharp lower contact. The upper contact contains detrital wood fragments which grade into a peaty mud. The west face shows a thickening of the sand layer to the south over $70 \mathrm{~cm}$, however, the south face indicates a uniform layer of consistent thickness. 
Trench SSX 2A, West Face

$5 \mathrm{ft}$.

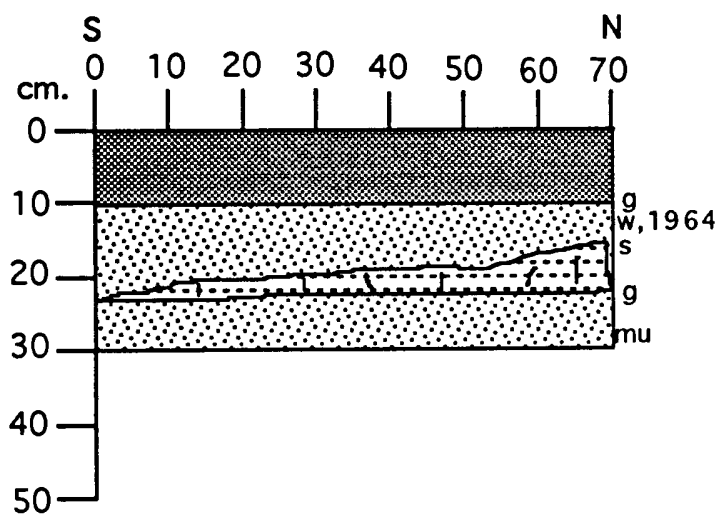

0-10 cm, peaty mud, gradational lower contact.

10-18 cm, sand, detrital wood fragments, sharp lower contact, 1964.

$18-23 \mathrm{~cm}$, rooted mud, gradational lower contact.

$23-30 \mathrm{~cm}$, muddy sand.
Trench SSX 2A, South Face

$5 \mathrm{ft}$.

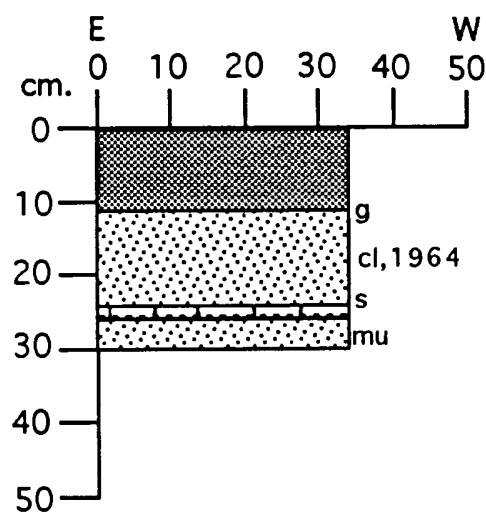

$0-11 \mathrm{~cm}$, peaty mud, gradational lower contact.

11-25 cm, sand, clean, sharp lower contact, 1964.

$25-26 \mathrm{~cm}$, rooted mud.

$26-30 \mathrm{~cm}$, muddy sand.

Figure 26. Neacoxie Creek trench 2A (core site SSX 754). 
Trench site SSX 2B, dug at grid core site SSX X (Figure 27), shows a peaty mud, sand, and rooted mud sequence from top to bottom of the trench. The clean sand layer, fairly uniform in thickness, has a lower irregular (not intruded) contact and an upper gradational contact. In both faces, there is no evidence of clastic dike or sill intrusion.

\section{Prehistoric Events?}

Weak subsidence horizons are located in five grid cores (SSX VIII, IX, X, XI, and XXVII) on the eastern bank of Neawanna Creek (Figure 21). The upper contact of the subsided muddy peat ranges from $29-55 \mathrm{~cm}$ in depth. Site SSX IX has a SCL (lamination); however, the remainder of the cores mentioned do not contain any SCL or TSL above the peat.

\section{Drainage to the East of Neacoxie Creek (SSXa)}

\section{Location}

This unnamed drainage directly east of Neacoxie Creek (Figure 28) is bounded to the west by a $7.3 \mathrm{~m}(24 \mathrm{ft}$.) sand dune (the eastern boundary of Neacoxie Creek). The northern and eastern limits of the drainage gradually increase in elevation with increasing distance from the creek axis. The drainage mouth, $243 \mathrm{~m}$ west of HWY. 101, empties into the Necanicum estuary.

\section{Event}

\section{Observations}

There were no direct observations of the 1964 surge impacts within this drainage, however extensive surge impacts are noted for the opposite bank on the southern side of the Necanicum estuary (Figure 28$)$. Specifically, runup reached $4.1 \mathrm{~m}(13.5 \mathrm{ft}$.), 
Trench SSX 2B, West Face

$3 \mathrm{ft}$.

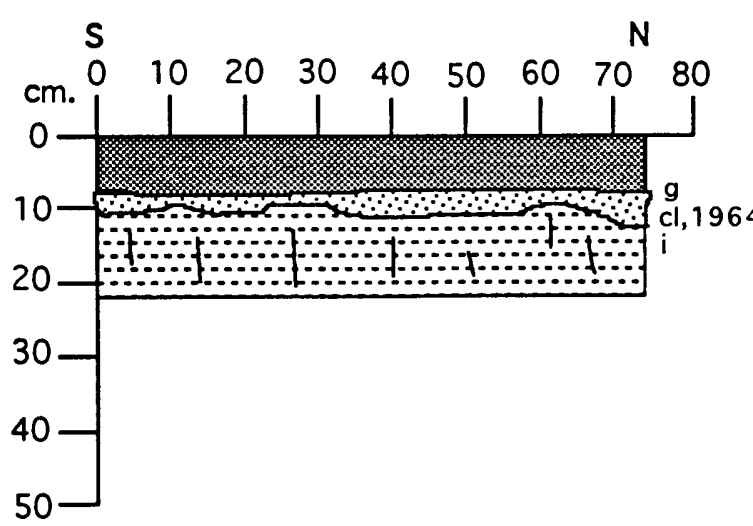

$0-8 \mathrm{~cm}$, peaty mud, gradational lower contact.

8-9 $\mathrm{cm}$, sand, clean, irregular lower contact, 1964.

$9-21 \mathrm{~cm}$, rooted mud.
Trench SSX 2B, South Face

$3 \mathrm{ft}$.

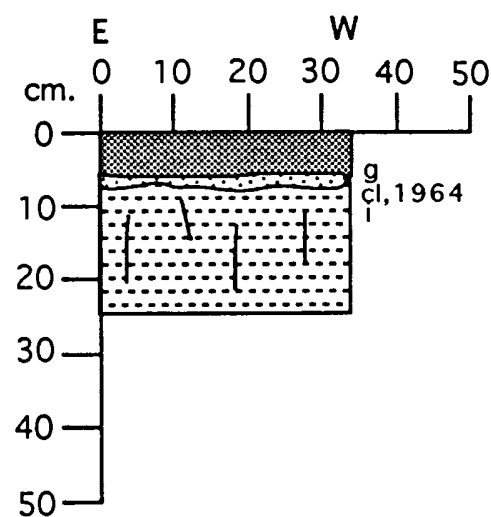

0-6 cm, peaty mud, gradational lower contact.

$6-8 \mathrm{~cm}$, sand, clean, irregular lower contact, 1964.

$8-25 \mathrm{~cm}$, rooted mud.

Figure 27. Neacoxie Creek trench 2B (grid core site SSX X). 


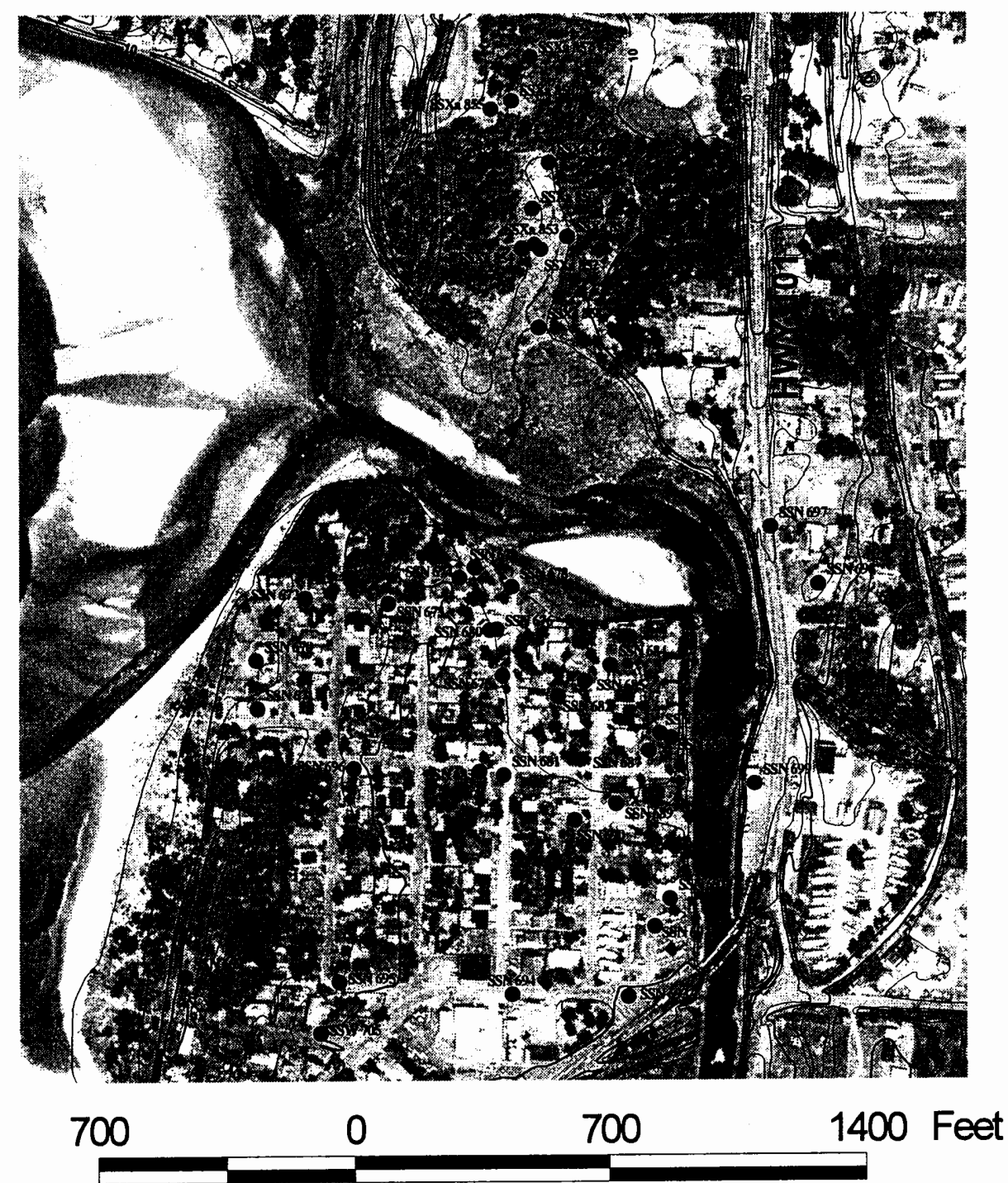

- Observation sites and core locations $2 \mathrm{ft}$. Contours
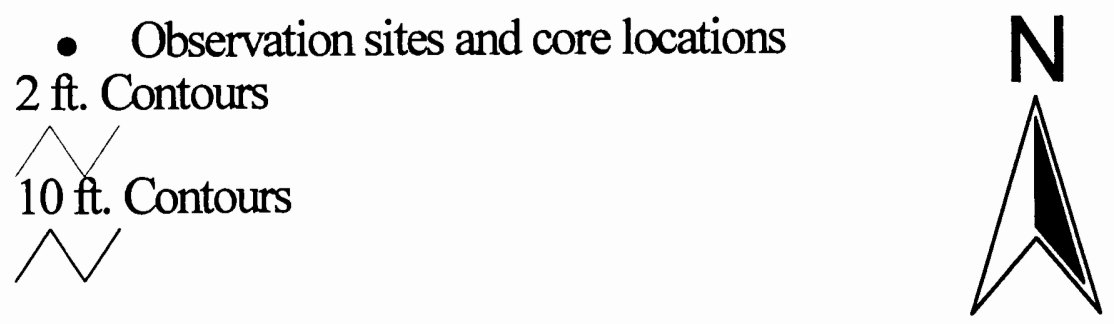

Figure 28. Drainage to east of Neacoxie Creek and Venice Park observation and core sites. 
with cars and drift logs being moved 10's to 100 's of meters. Thick sand deposits were deposited in Venice Park (Figure 29) and also (16 cm thick at SSW 722) were deposited on the tidal marsh/shoreline immediately downstream from the HWY. 101 bridge (T. Horning, personal communication, 1996).

\section{Gouge Coring}

Ten gouge cores, SSXa 849-857, were logged in this drainage. Deep penetration was not a problem in some cored sections with maximum penetration reaching up to $120 \mathrm{~cm}$. All cores except for SSXa 857 (furthest core north) contained sand layers or traces of sand shallow in the section from 0-50 cm. Both core sites SSXa 855 and 856 contained sand layers 0.5 centimeters thick within a peaty mud at 7 and $11 \mathrm{~cm}$, respectively. Figure 30 shows core sections of SSXa 853 and 855-856.

\section{Trenching}

Trench SSXa 4A was dug at gouge core location SSXa 850. Both the west and south faces were sketched and described in detail (Figure 31). Interfingering of sand and mud occurred between 20 and $33 \mathrm{~cm}$. Further down section, muddy peat and sand surrounded mud inclusions. Although this view is fairly detailed, the general lithology matches that of what was logged in gouge core SSXa 850. The apparent clastic sill intrusions demonstrate liquefaction of the underlying sand layers.

1700 AD Event

Gouge Coring

Five of the cores taken to document the 1964 event (SSXa 850, 854-856) included deeper buried peaty horizons with sand bodies (Figure 32). Sites SSXa 850, 


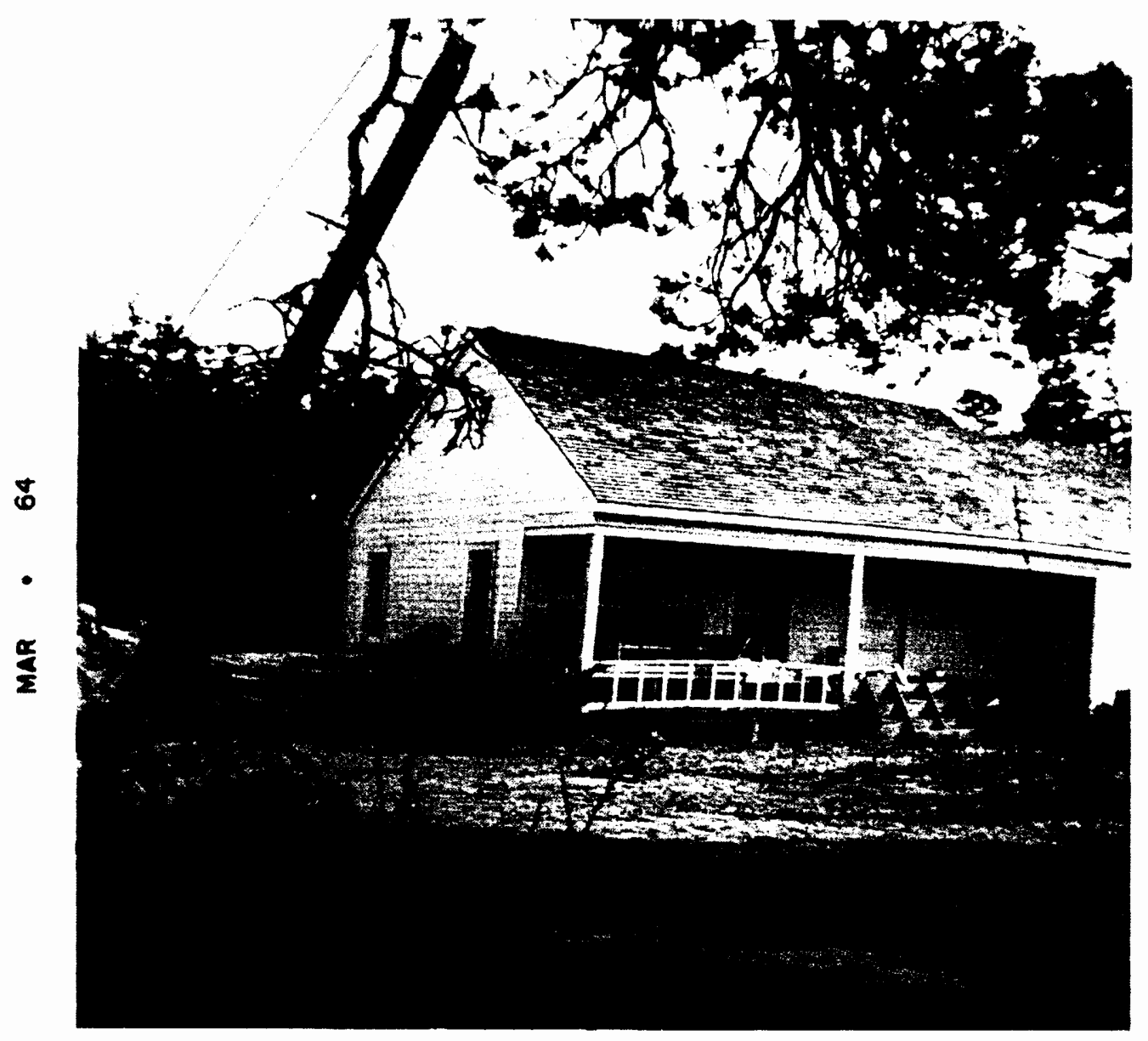

Figure 29. House located on 26th and Pine in Venice Park area. 1964 Tsunami drift $\log$ with sand sheet $10-15 \mathrm{~cm}$ thick. Behind the $\log$ the sand deposit increases to roughly $20-30 \mathrm{~cm}$. Photographer: Bettie Hanson. 
N

$S$

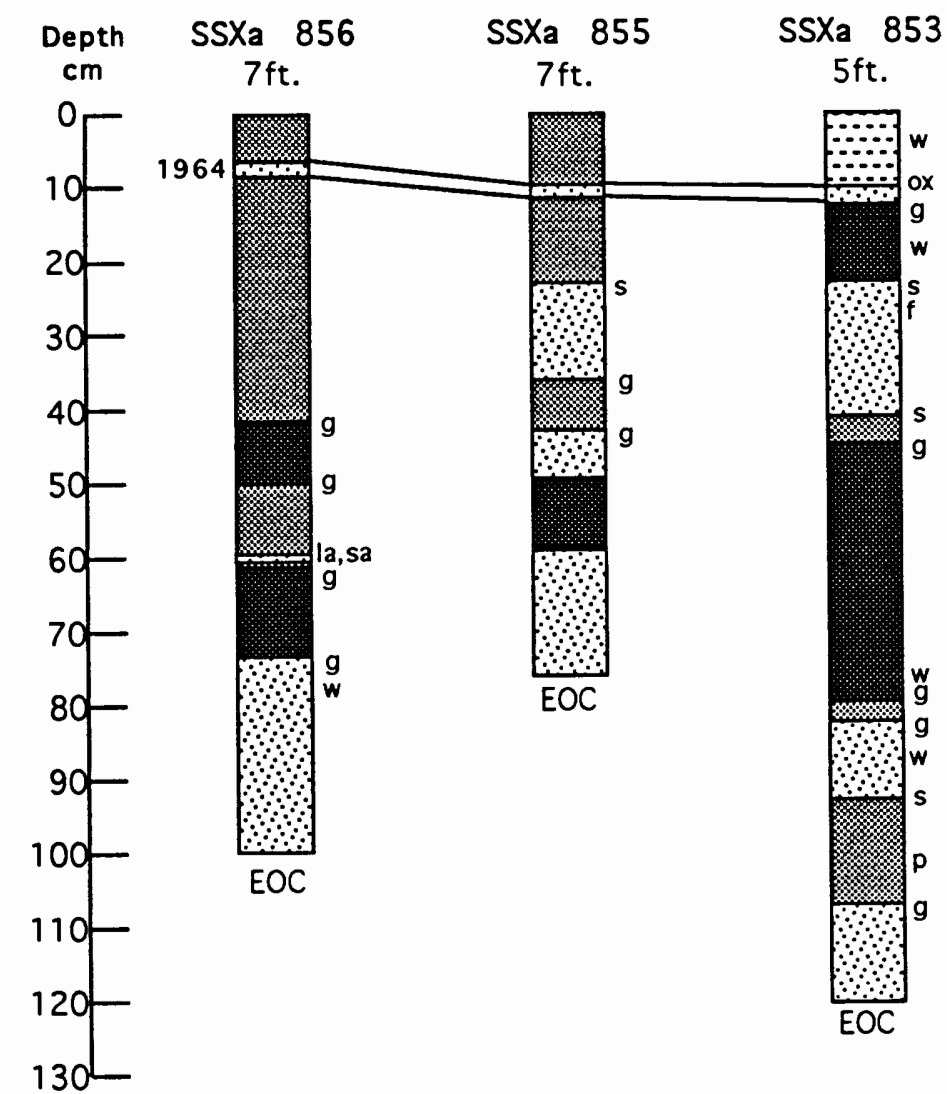

Figure 30. Drainage to east of Neacoxie Creek, cores SSXa 853, 855-856. 
Trench SSXa 4A, West Face $7 \mathrm{ft}$.

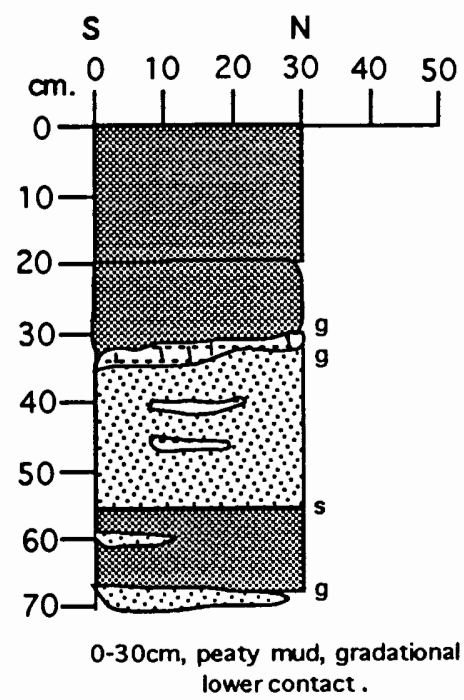

$30-33 \mathrm{~cm}$, rooted mud, gradational lower contact.

34-57 cm, sand, mud inclusions, sharp lower contact.

57-68 peaty mud, sand inclusions, grada tional lower contact.

$68-70 \mathrm{~cm}$, sand.
Trench SSXa 4A, South Face

$7 \mathrm{ft}$.

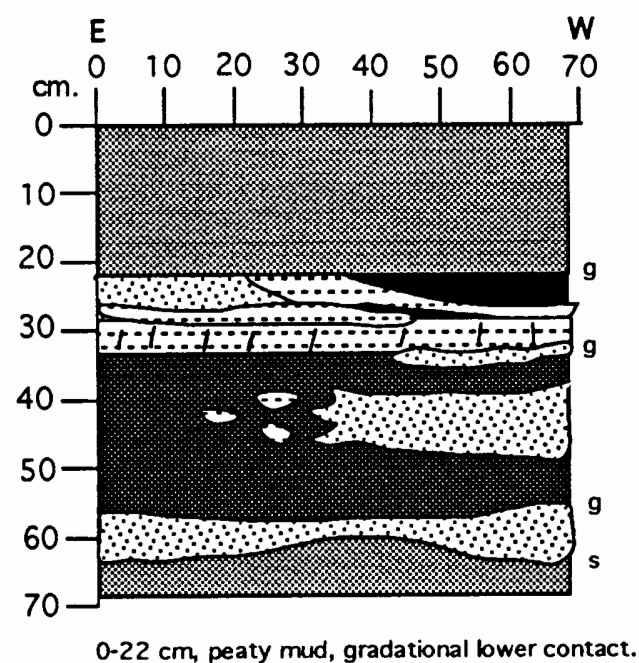

$22-30 \mathrm{~cm}$, peat, sand, and mud fingers.

$30-33 \mathrm{~cm}$, rooted mud, lower gradational contact.

$33-56 \mathrm{~cm}$, muddy peat, sand inclusions, lower gradational contact.

$56-64 \mathrm{~cm}$, sand, lower sharp contact.

64-68 cm, peaty mud.

Figure 31. Drainage to east of Neacoxie Creek, trench 4A (core site SSXa 850). 


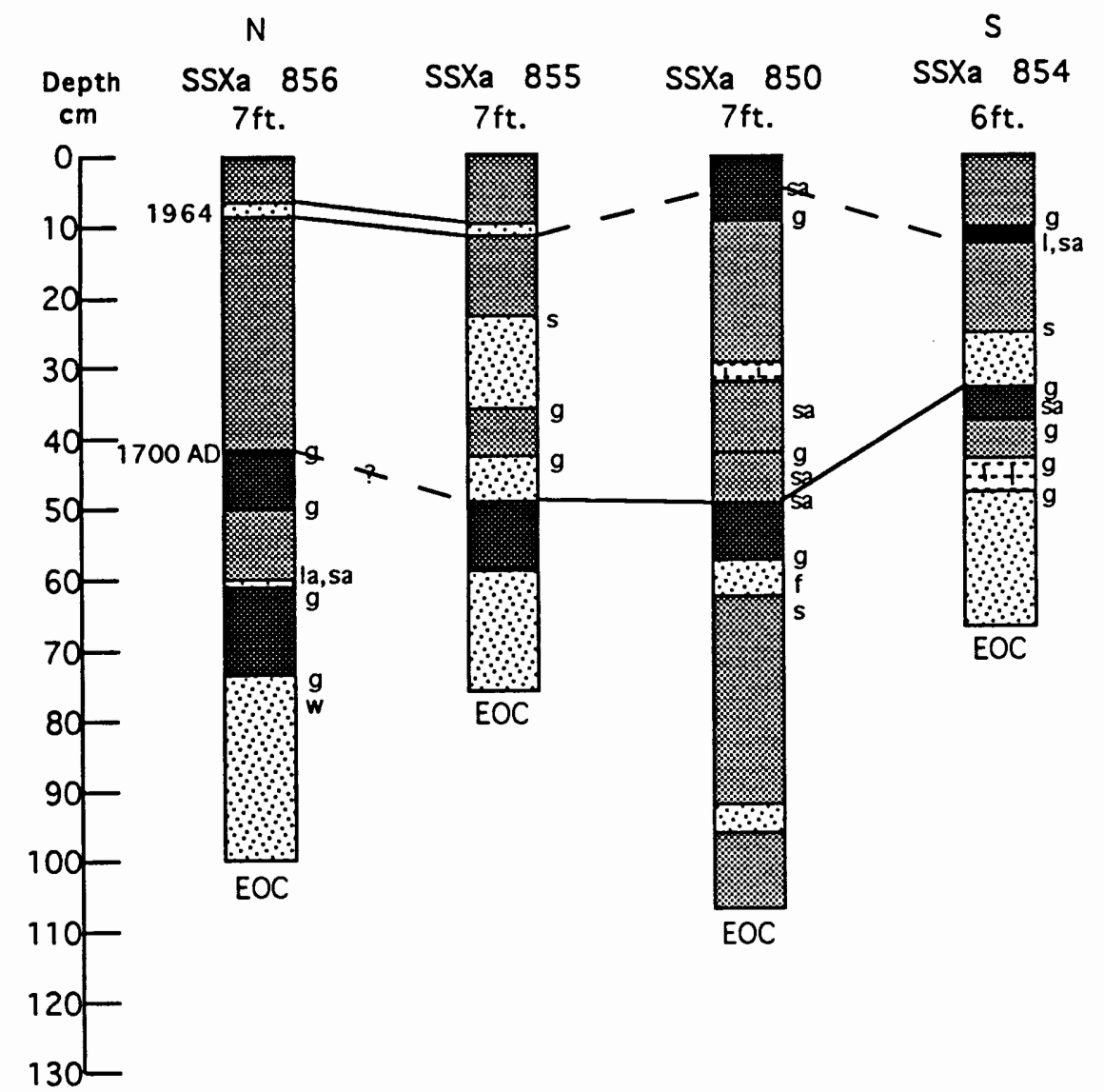

Figure 32. Drainage to east of Neacoxie Creek, prehistoric horizons? 
854-856 show a sand layer or lamination (SCL) with a lower primarily sharp to gradual contact with a buried peat to muddy peat at $32-60 \mathrm{~cm}$ deep. Site SSX 856 contains two possible buried peaty layers also below the 1964 event. Site SSXa 850 indicates a reversed stratigraphy with the fining upward sand underlying the buried peat and a trace of sand above the muddy peat. Generally, these cores lack the expected sequence of sand layers between a peaty layer and an overlying mud. The placements of the deeper sand layers (pre-1964) are inconsistent and discontinuous between core sites. Stanley Lake (SSS)

Location

Stanley Lake is located just south of the Seaside/Gearhart Airport at the northeast corner of the study area. The western boundary of this N-S trending lake is confined by a cobble ridge, and the eastern boundary gradually increases in elevation to eventually meet the foothills of the Coast Range. The southern extent of the Stanley Lake study area is just south of the intersection of 4 th Street and 12th Avenue. Tide gates regulated the water flux of Stanley Lake until mid-summer 1996. Stanley Lake now connects with the Necanicum Estuary to the north by Mill Creek. Gouge core and observation sites are located in Figure 33.

1964 Event

Observations

There are no reports of 1964 surges reaching the Stanley Lake area. However, runup reached up to $4.7 \mathrm{~m}$ (15.5 ft.) and drift logs were reported from the Mill Creek mouth and east banks of the Necanicum estuary (Figure 28) (T. Horning, personal 


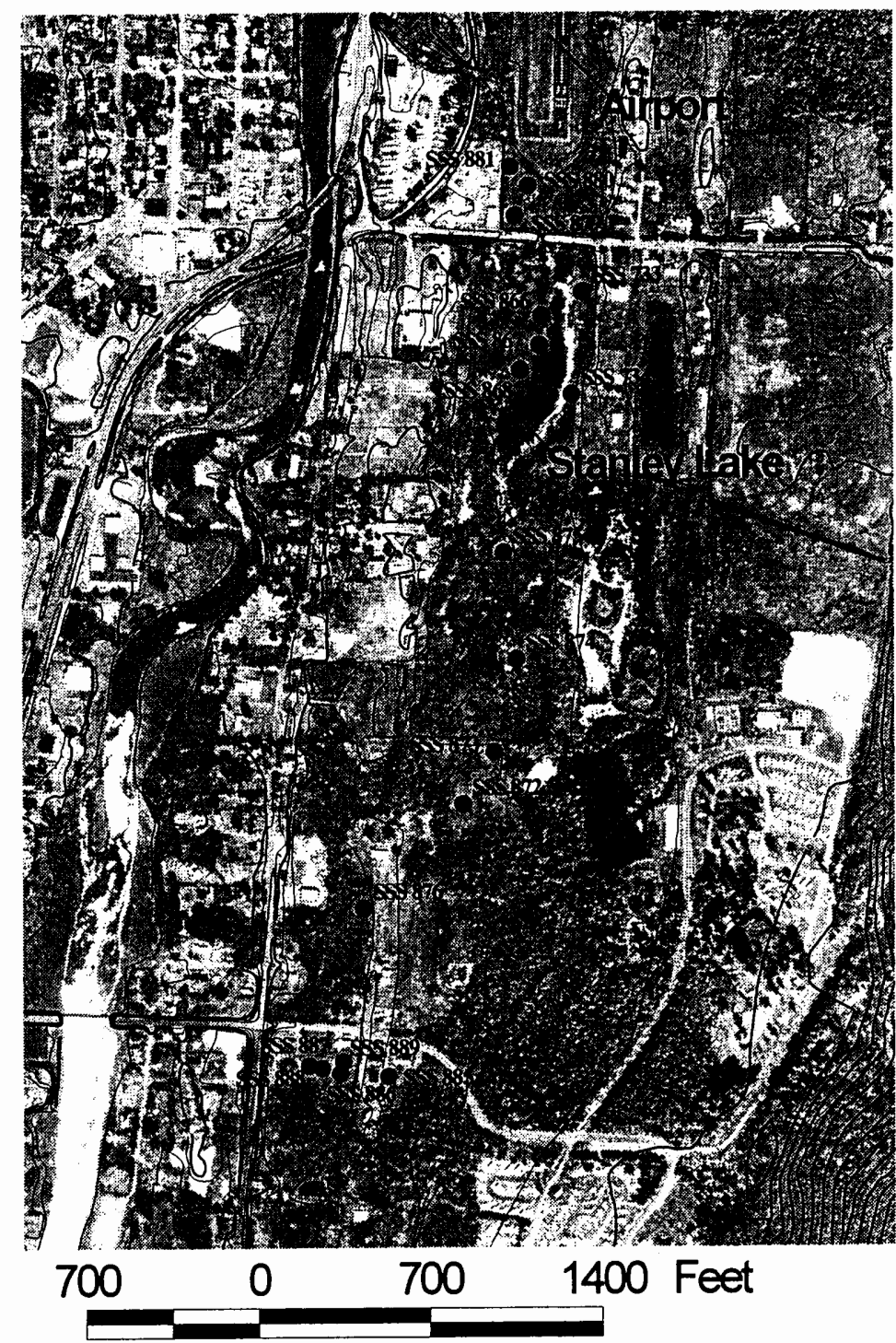

- Core locations

$2 \mathrm{ft}$. Contours

$10 \mathrm{ft}$. Contours

入

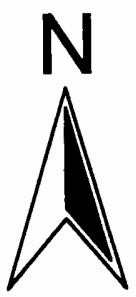

Figure 33. Stanley Lake core locations. 
communication, 1996).

1700 AD Event

Gouge Coring

Coring at Stanley Lake was difficult due to a high water table causing portions of the cores to be unrecoverable. Eight gouge cores were taken in the immediate area surrounding Stanley Lake. Core SSS 733 reached maximum penetration for the area of $250 \mathrm{~cm}$. However, the average core depth reached about $150 \mathrm{~cm}$.

On the east side of Stanley Lake, SSS 733 and 734 display differing stratigraphies (Figure 34). Site SSS 734 indicates a sand layer (SCL) with a lower sharp contact at $88 \mathrm{~cm}$ with a muddy peat. The sand deposit is $13 \mathrm{~cm}$ thick with an overlying thick deposit of peaty mud.

Remaining core samples were taken on the western side of Stanley Lake. Immediately to the southwest of the Seaside/Gearhart Airport, three cores were taken, SSS 879-881 (Figure 35). All three cores have sand layers (TSL) overlying peaty mud or muddy peat. Rooted mud overlies the sand layers. Lower in the sections of these cores, variable deposits of sand and underlying cobbles inhibit further gouge core penetration. The sandy muddy peat to peaty mud contacts averaged $62 \mathrm{~cm}$ in depth from the surface. Cores taken at the south end of the airport runway showed extensive evidence of fluidization including clastic sand dikes and sills. Therefore, these cores were not logged for paleotsunami evidence.

Gouge cores, SSS 866-868 (Figure 36), were taken along the western edge of 


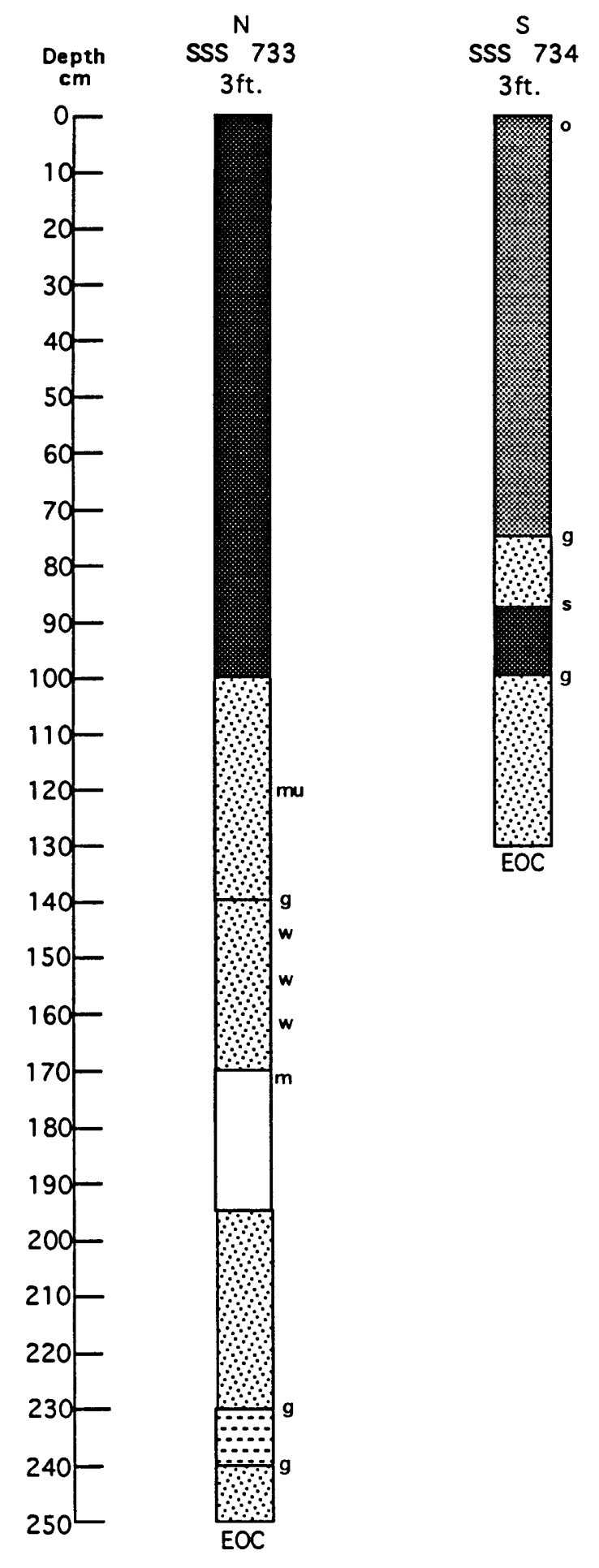

Figure 34. Stanley Lake cores SSS 733 and 734. 
N

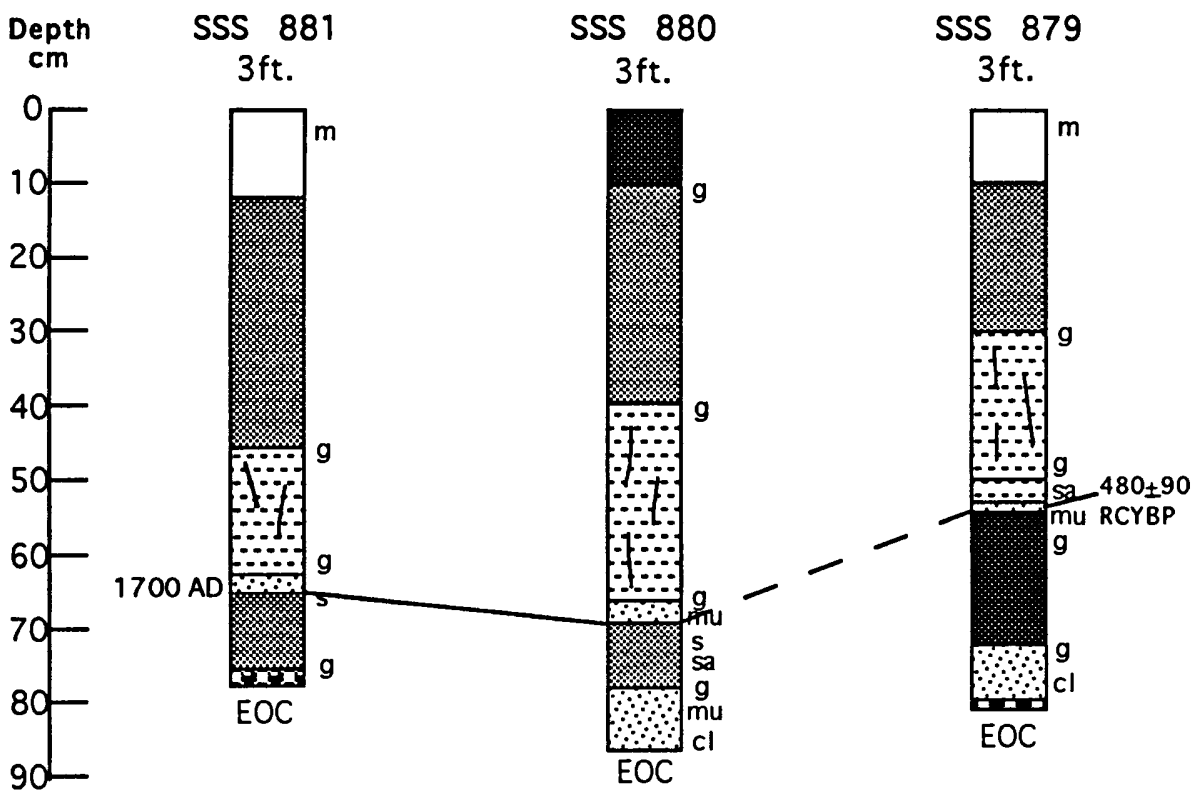


N

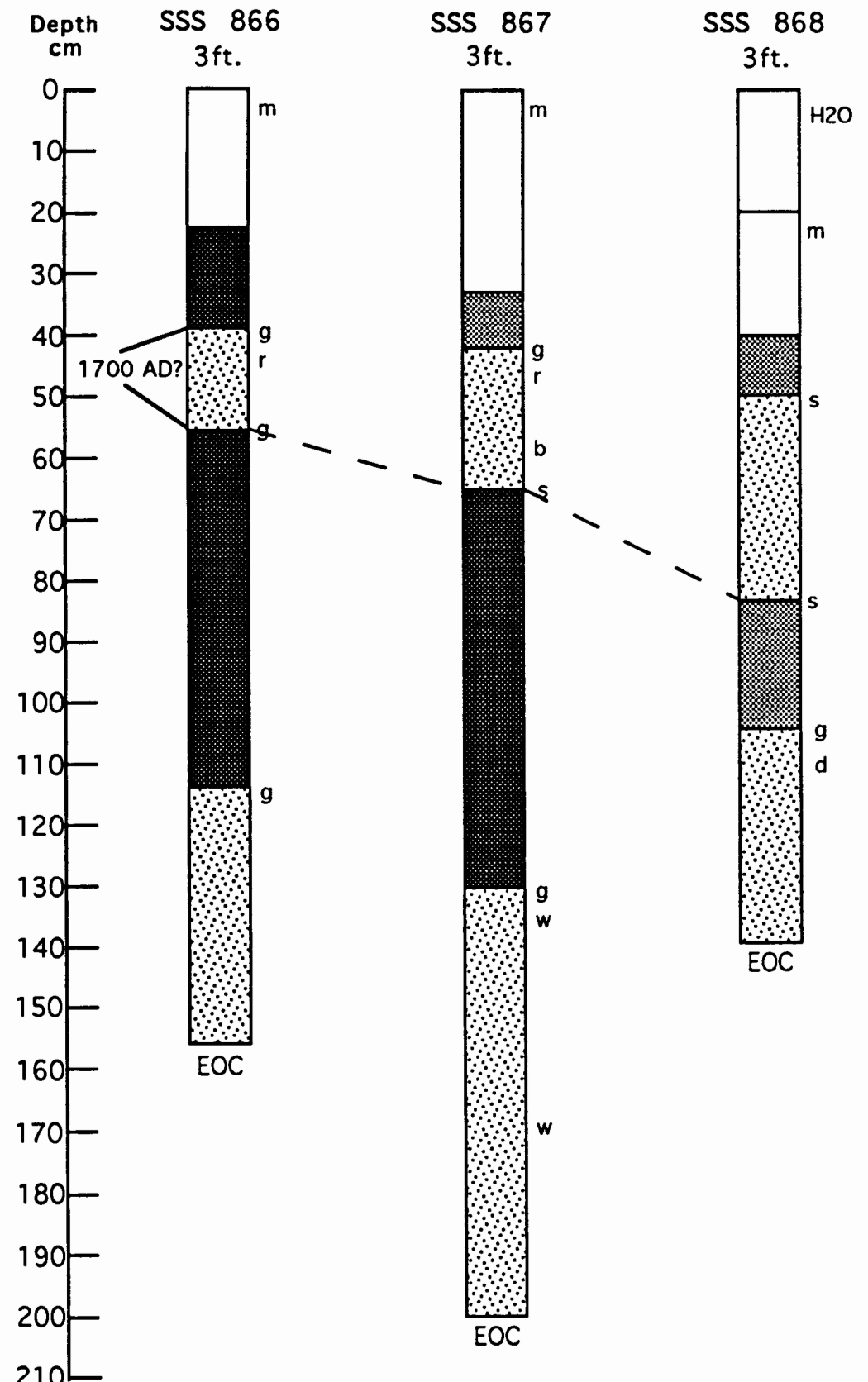

Figure 36. Stanley Lake cores SSS 866-868. 
Stanley Lake. All three cores show a continuous sand horizon thickening to the south. However, a muddy peat encloses this sand layer, so a correspondence to abrupt subsidence cannot be established. Sand layers thicken from $17 \mathrm{~cm}$ at SSS 866 to $33 \mathrm{~cm}$ at SSS 868. These cores end in a fairly dense sand, no cobbles or gravel were encountered.

Further south, cores SSS 872-876 indicate a decreasing sand thickness to the south again within a peaty mud or muddy peat (Figure 37). At SSS 875, this four centimeter sand layer (at $46 \mathrm{~cm}$ ) is slightly muddy. Site SSS 874 (at $44 \mathrm{~cm}$ ) contains a sand layer of 0.5 centimeters within a muddy peat. In SSS 873 and 872 , there is no sand present $40-50 \mathrm{~cm}$ in depth from the surface, although, a sand layer is evident within the interval of $140-150 \mathrm{~cm}$ of both cores. In both SSS 872 and 873 , the cores show very similar stratigraphy. South of SSS 872 , SSS 876 shows a sand layer within a peaty mud. This sand fines upward and has a sharp lower contact. Due to a lack of a distinct buried peaty unit and corresponding subsidence contact, it is not known what the relative stratigraphic ages are of the anomalous sand layers.

Farther south, SSS $887-889$, the sand is not found within a consistent horizon (Figure 38). Some contacts are gradual while others are sharp, some contain basal sand while others do not, and some sand deposits are associated with organics and detrital wood fragments. There is little to no similarity in sand layer depth, thickness or stratigraphic sequences between these cores. 
$\mathrm{N}$

$\mathrm{S}$

69

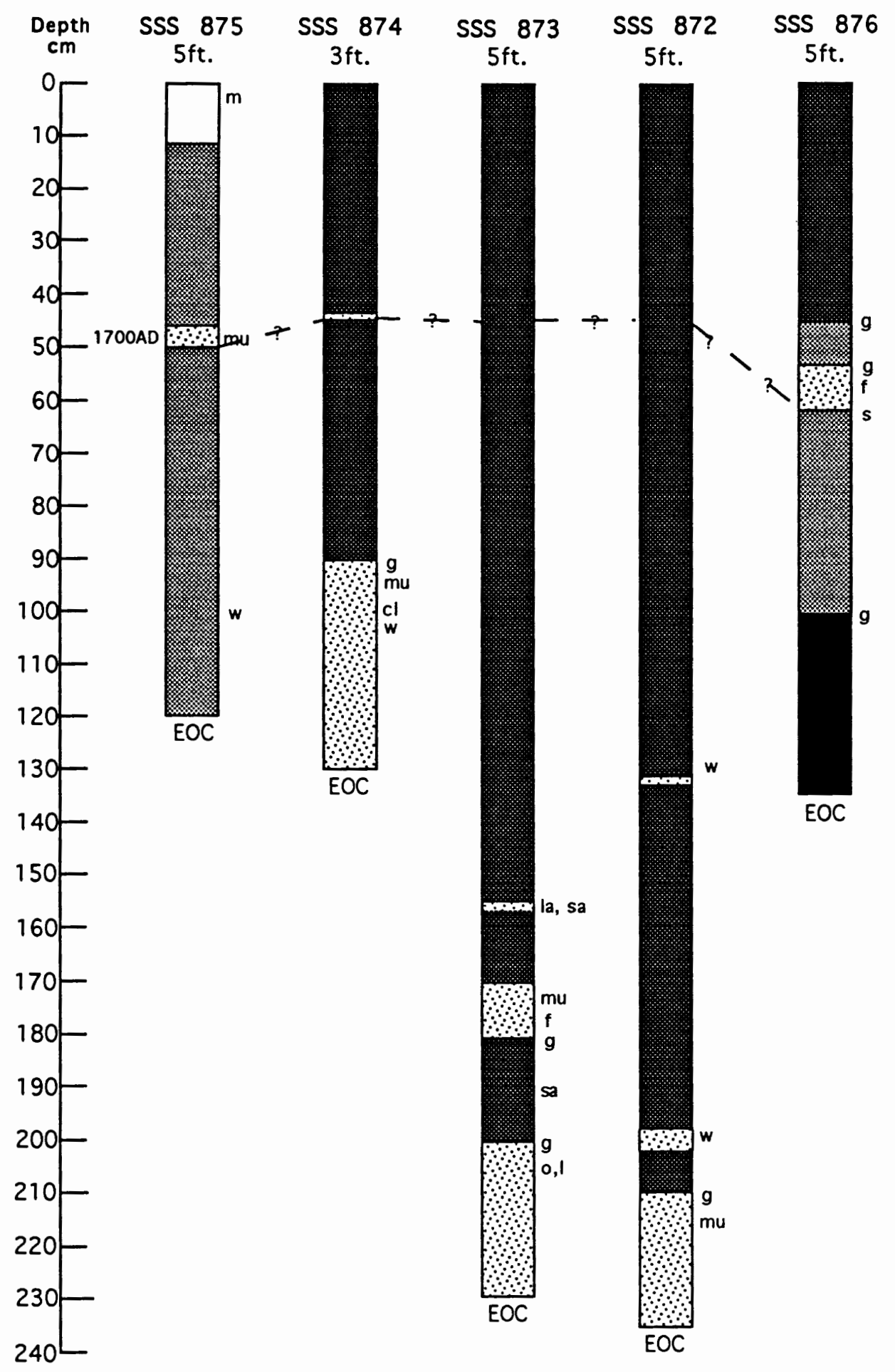

Figure 37. Stanley Lake cores SSS 872-876. 


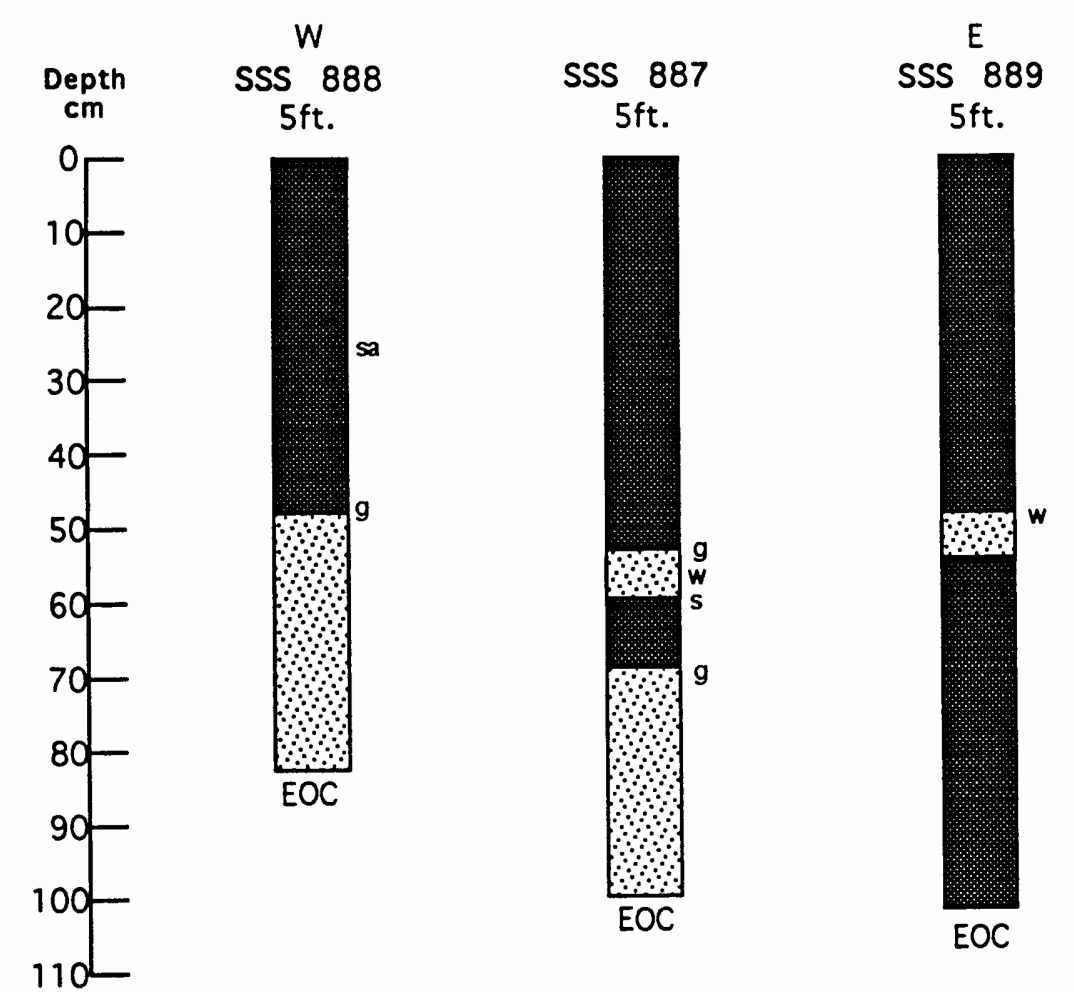

Figure 38. Stanley Lake cores SSS 887-889. 


\section{Radiocarbon Samples}

Two radiocarbon samples taken from SSS 879 were analyzed. Both peat samples were retrieved by pound core. SSS 879 at $55-65 \mathrm{~cm}$ returned a date of $910 \pm 70$ RCYBP. This sample contained a relatively thick peaty section, so the old date was suspect. Therefore, an additional, more confined peat sample was collected directly below the sand contact at $54 \mathrm{~cm}$ for AMS dating. This sample produced a new date of $480 \pm 90 \mathrm{RCYBP}$. This age is not inconsistent for a pre-event peat surface developed prior to the $1700 \mathrm{AD}$ subsided event.

\section{Diatom Analysis}

Site SSS 879 showed a contact between a muddy peat and an overlying sand layer at $54 \mathrm{~cm}$. A sample for diatom analysis was taken below the contact at $56 \mathrm{~cm}$. This sample showed a considerable freshwater diatom influence with such species as Eunotia pectinalis and Navicula radiosa. The sample from above the contact showed a change to a brackish to marine diatom influence. Marine diatoms include Cocconeis scutellum and Thalassiosira pacifica, and brackish diatoms were dominated by Synedra fasciculata. The diatom data confirm an abrupt event of paleosubsidence from high marsh to low marsh recorded at the 0.5 meter depth interval (E. Barnett, personal communication, 1997).

Neawanna Creek (SSW)

Location

Neawanna Creek, which roughly trends N-S, is directly east of the Necanicum River, and its mouth empties directly into the Necanicum Estuary. The Neawanna 
wetlands extend along the eastern lowlands of Seaside. The narrow wetlands are relatively contiguous from the north (HWY. 101 bridge) to the south totaling a distance of about four kilometers. Eastern boundaries are formed at alluvial slopes of terraces at the base of the Coast Range foothills. The western boundaries of the Neawanna wetlands run parallel to cobble beach ridges along most of the tidal creek. Tidal influence in the modern creek diminishes from north to south, with beaver dams constricting freshwater runoff at the southernmost end of the wetlands.

1964 Event

\section{Observations}

Observations of the 1964 tsunami impacts along the Neawanna Creek include sites SSW 700-711. Site SSW 705 indicated live fish deposited in a field with a water mark at $3.4 \mathrm{~m}(11 \mathrm{ft}$.$) . No flooding occurred in the area near SSW 706. Sites SSW$ 700 and 701, along the northeastern bank of Neawanna Creek, had water marks of 3.0 $\mathrm{m}(10 \mathrm{ft}$.) from the tsunami waves, flush with one home owner's yard. On the western bank, SSW 702 indicated a water mark at $3.2 \mathrm{~m}$ (10.5 ft.). At SSW 703 and 704, a sand layer and water mark at 2 and $2.3 \mathrm{~m}(6.5$ and $7.5 \mathrm{ft}$.) respectively were observed. At these localities standing waves in prolonged surges were observed as water flooded over a point bar marsh at an elevation of $3 \mathrm{~m}$. The next day the site was observed to contain sand deposits overlying flattened grass leaning up river (J. Spillman, personal communication, 1996). Figure 39 shows observation sites and core locations for Neawanna Creek from its mouth to 12 th Avenue. Site SSW 707 indicated a water mark at 1.8-1.5 m (6-5 ft.), immediately southeast of 12 th Avenue bridge. However, 


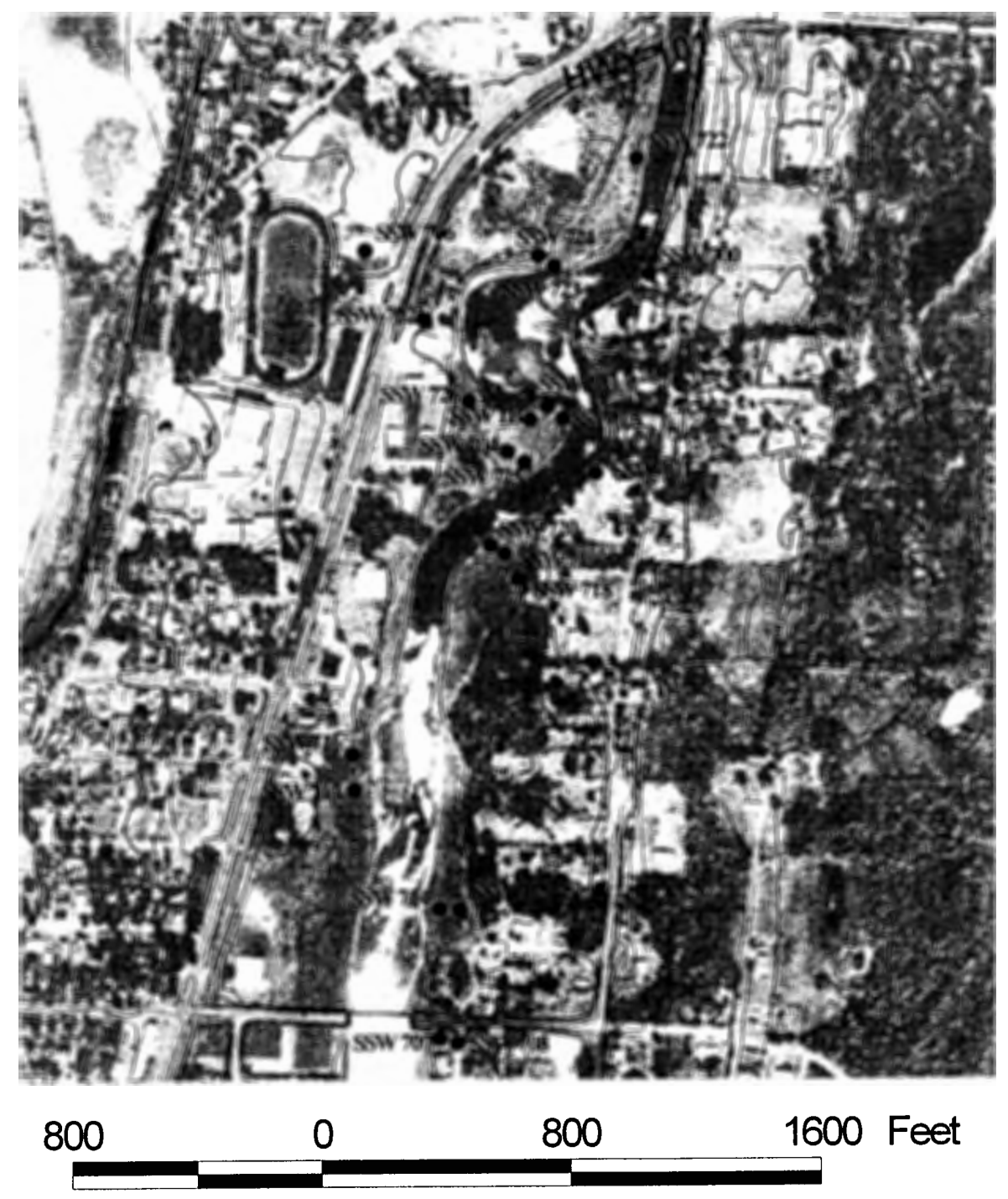

- Observation sites and core locations $2 \mathrm{ft}$. Contours $10 \mathrm{ft}$. Contours N

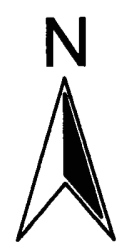

Figure 39. Neawanna Creek observation and core locations between its mouth and 12th Ave. 
SSW 708 was not affected by flooding (2nd Street).

Remaining observations to the south (SSW 709-711) indicated that no flooding occurred at these locations. Figure 40 shows Neawanna Creek observations and core locations from 12th Avenue to south of Broadway Drive bridge.

\section{Gouge Coring}

The search for shallow 1964 sand deposits involved sixteen cores taken along the Neawanna Creek coastal wetland. Farthest to the north, cores SSW 722, 723, 725 and 726 show a distinct, thinning, 1964 sand sequence (Figure 41). SSW 722 contains a 15 cm thick sand layer overlying rooted mud. At SSW 723, the sequence is similar; however, there are mud and sand laminations at 11 and $17 \mathrm{~cm}$. At SSW 726, sand thins to eight centimeters with a muddy sand layer at $11 \mathrm{~cm}$. Further south, SSW 725 contains a five centimeter thick muddy sand. All lower sand to rooted mud contacts are sharp for this area. Cores SSW 718-720 contain 1964 sand layers or laminations within either rooted mud or peaty mud sections (Figure 42). Just to the northwest of the Broadway Drive bridge crossing Neawanna Creek, SSW 757 and 756 indicate shallow sand layers with sharp lower contacts with muddy peat. To the southwest of Broadway Drive bridge, SSW 763 contains a sand lamination at four centimeters within a muddy peat. These core logs are represented in Figure 43. Finally, cores SSW 803808 contain a shallow, typically clean, sand horizon (Figure 44). Figure 45 contains observation sites and core locations from south of Broadway Drive to S Avenue. The stratigraphies of these cores are fairly complex and may 


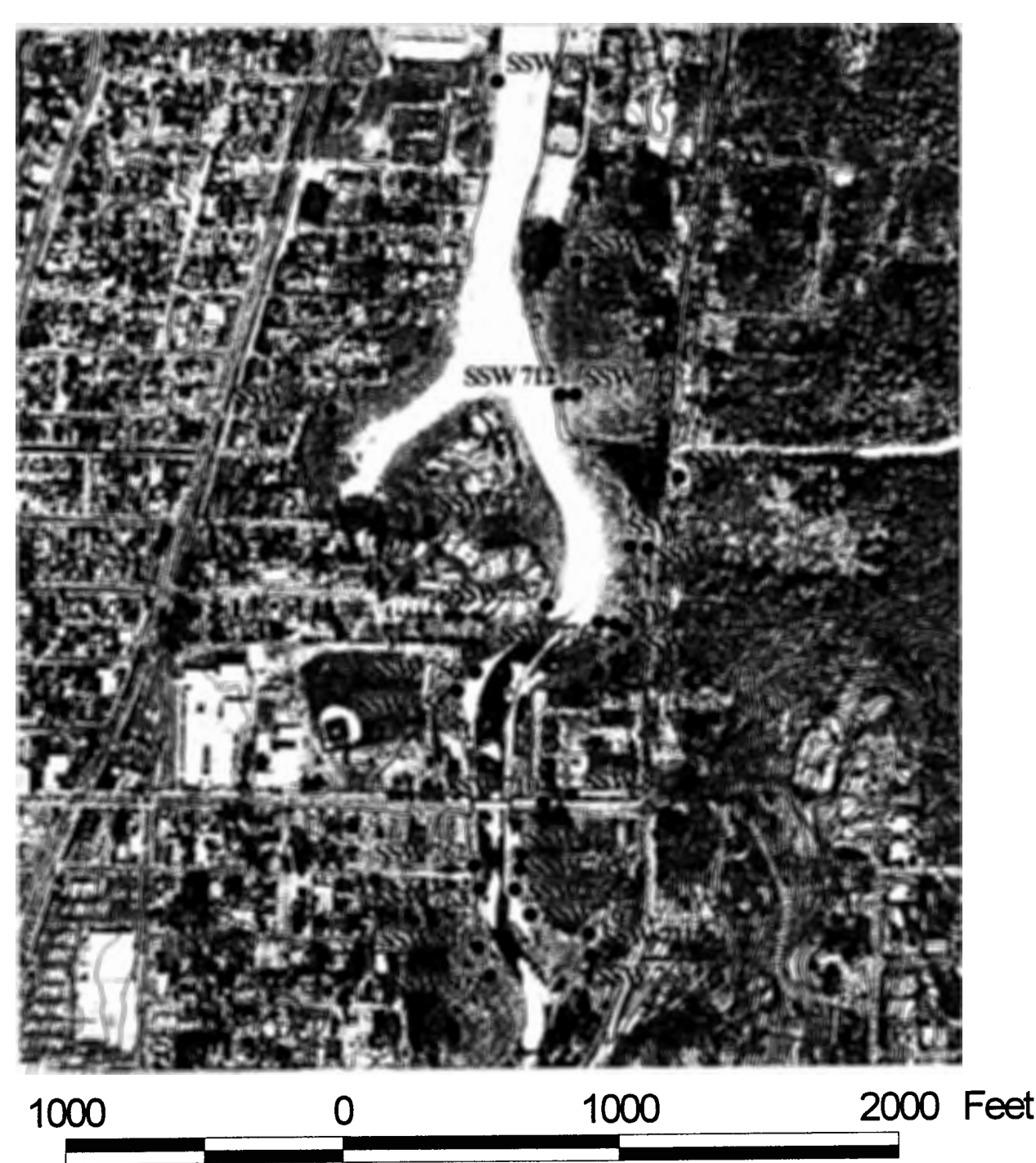

- Observation sites and core locations

$2 \mathrm{ft}$. Contours
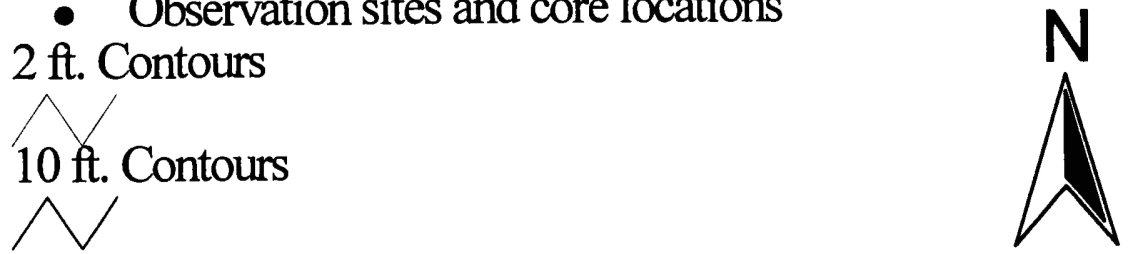

Figure 40. Neawanna Creek observation sites and core locations for 12th Ave. to south of the Broadway Dr. bridge. 


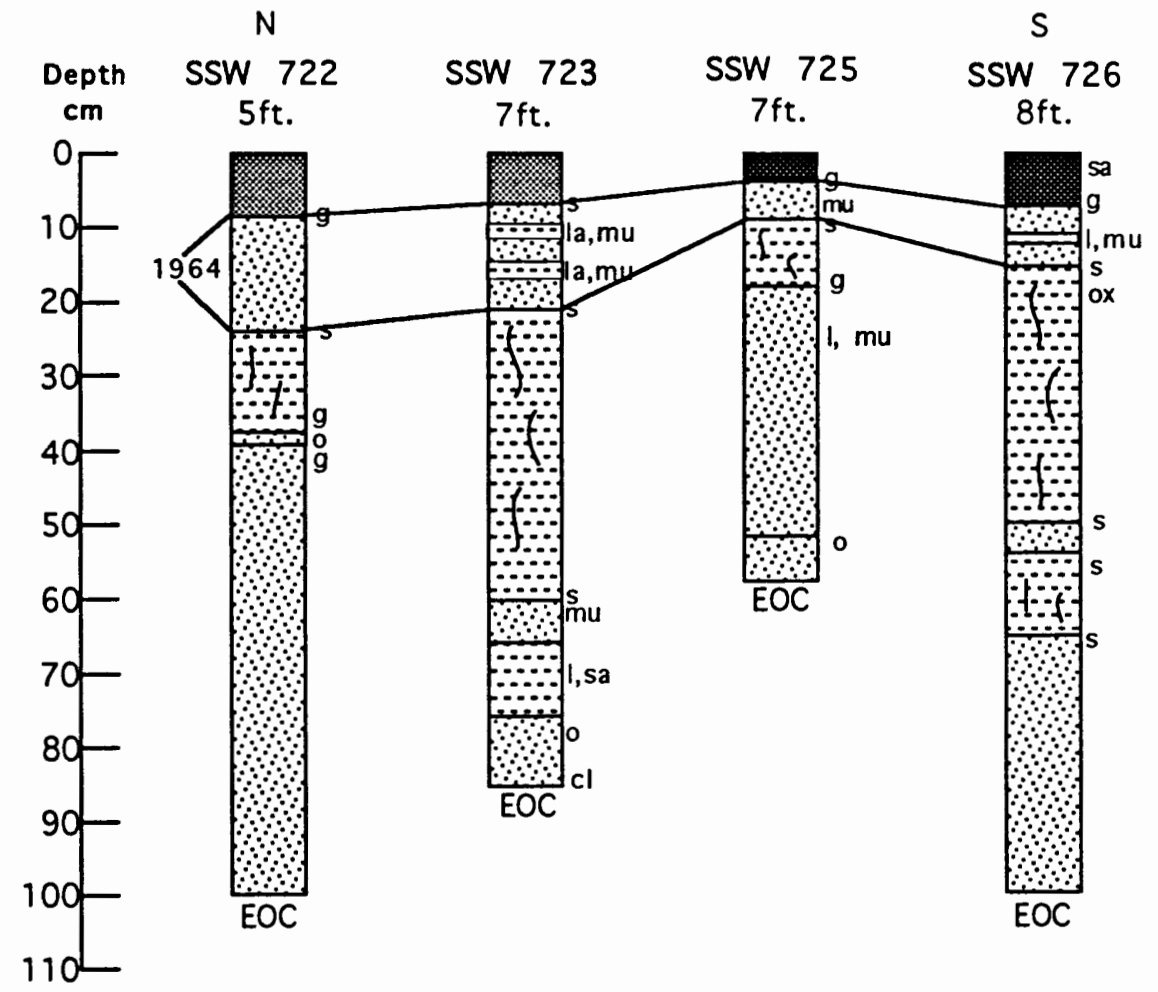

Figure 41. Neawanna Creek cores SSW 722, 723, 725, and 726. 


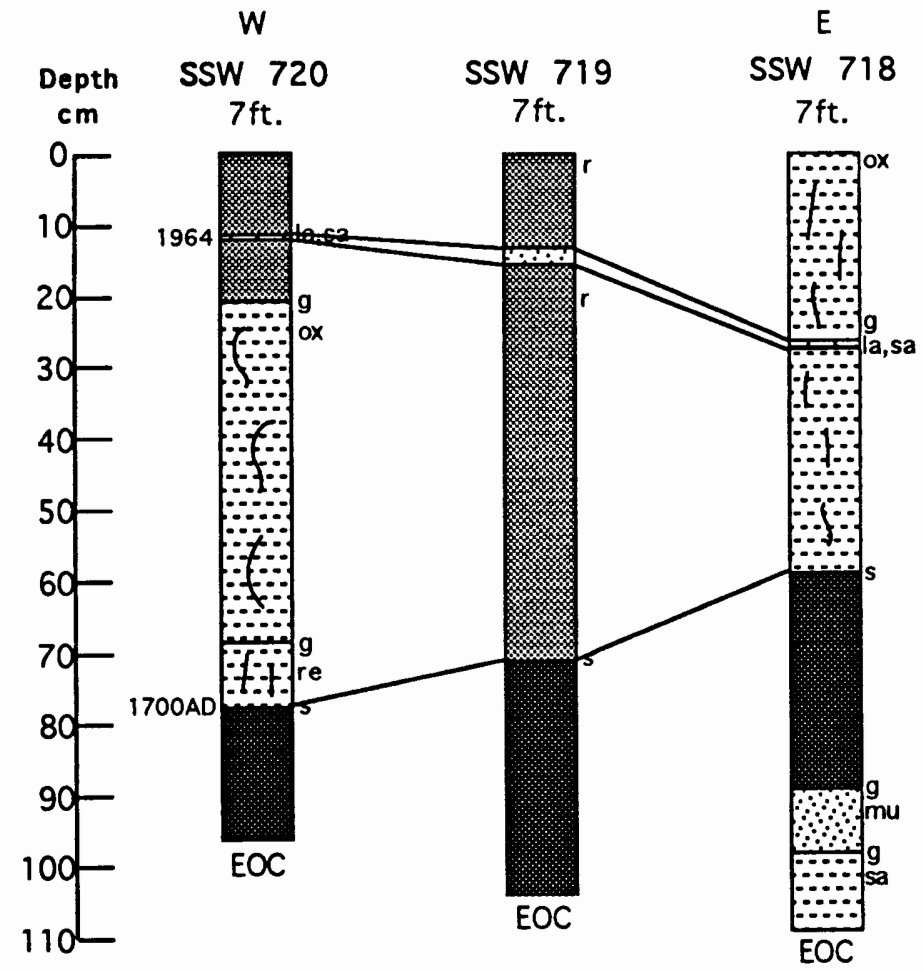

Figure 42. Neawanna Creek cores SSW 718-720.

N

$\mathrm{S}$

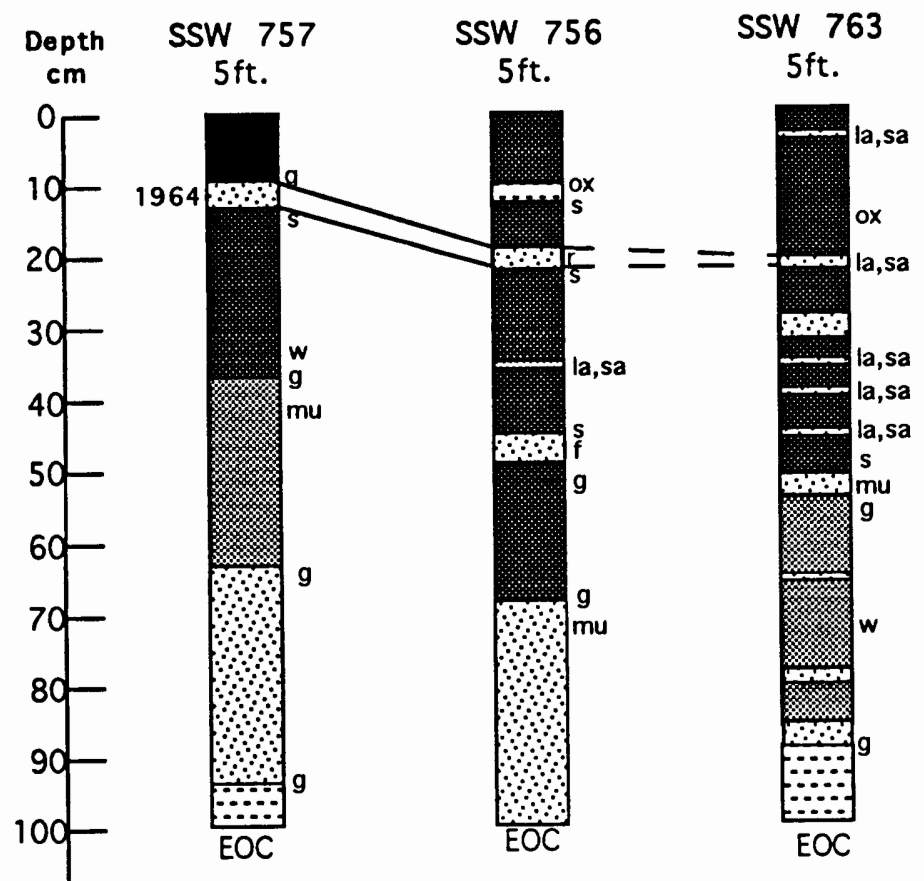

Figure 43. Neawanna Creek cores SSW 757, 756, 763. 
$N \quad S$

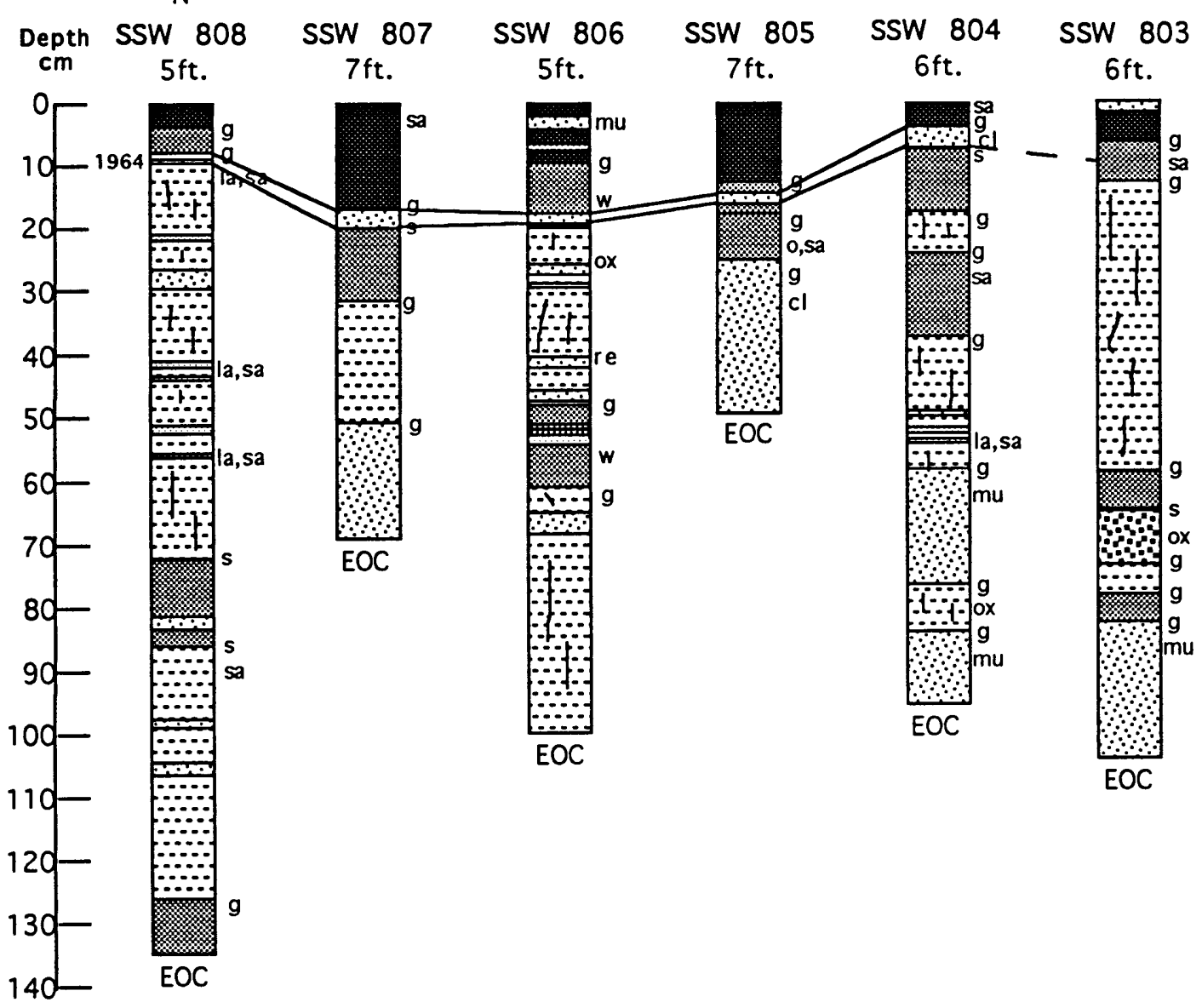

Figure 44. Neawanna Creek cores SSW 803-808. 

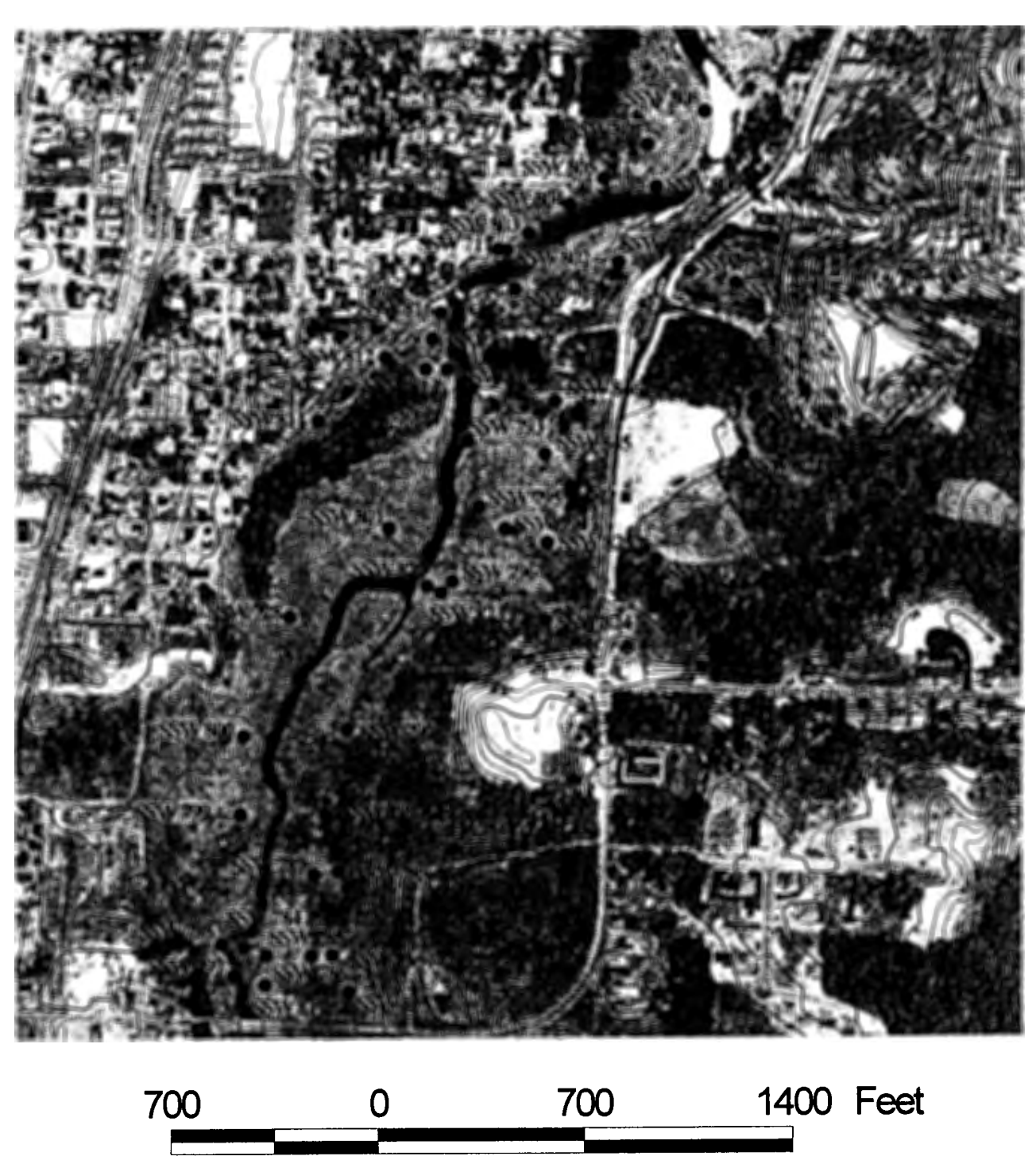

- Observation sites and core locations

$2 \mathrm{ft}$. Contours

$10 \mathrm{ft}$. Contours

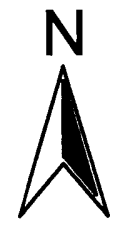

Figure 45. Neawanna Creek observation sites and core locations from south of Broadway Dr. to S Ave. 
indicate disturbance caused by urbanization.

\section{Grid Coring}

A total of 30 gouge cores were taken at three localities along the lower Neawanna Creek (Figure 46). These areas were affected by the 1964 tsunami, evidenced by direct observations (see above Observation section). Of the northernmost cores, SSW I-V, VIII and X show shallow sand layers fading in and out of the section (Figure 47). An E-W cross-section of cores XIII, XIV, XVI, and XVIII in the central grid show a sand layer which thins landward of Neawanna Creek (Figure 48). However, a relatively thick sand layer is present in SSW XVI.

A N-S cross-section from XXVIII, XXVII, XXVI, and XXIX on the southeastern grid contains fine sand laminations from the 1964 event at 8 and $13 \mathrm{~cm}$ which grade to a thicker single sand layer $(1 \mathrm{~cm}$ at $4-5 \mathrm{~cm}$ depth), to shallow sand traces, and then to no sand being present (Figure 49). The E-W cross-section of XXVIII, XXII, and XXI shows thinning of sand laminations landward (Figure 50). The westernmost cores (closer to the creek) contain two sand laminations, indicating two possible surges. 


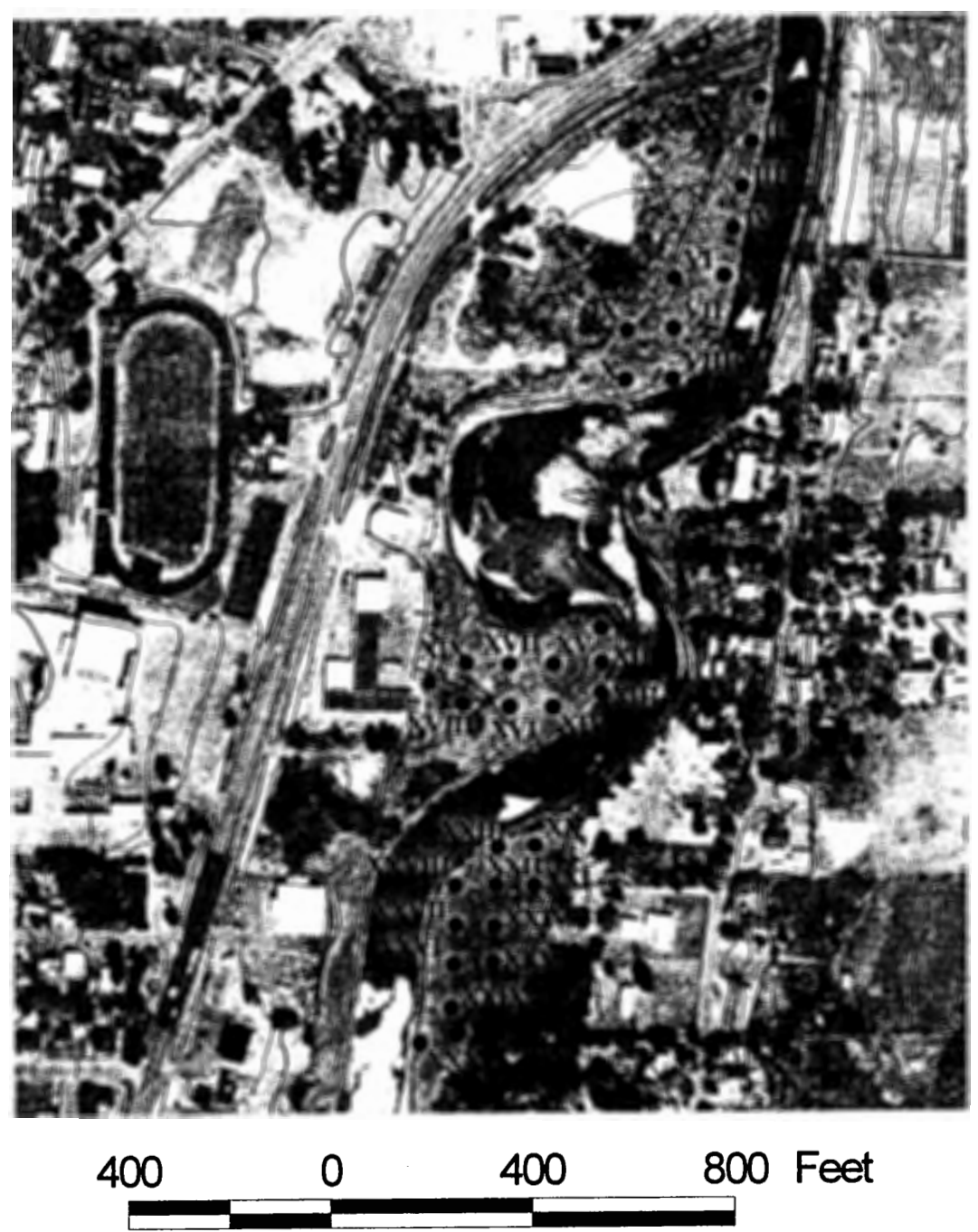

- Core locations

$2 \mathrm{ft}$. Contours
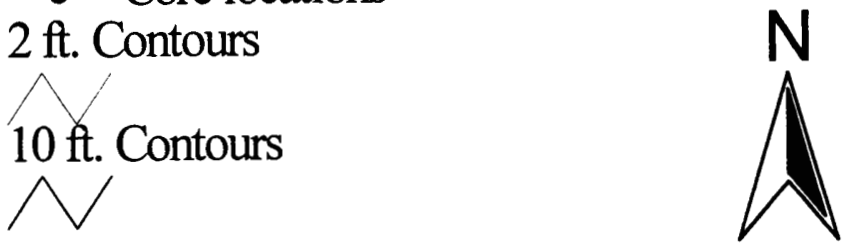

Figure 46. Neawanna Creek grid location map. 


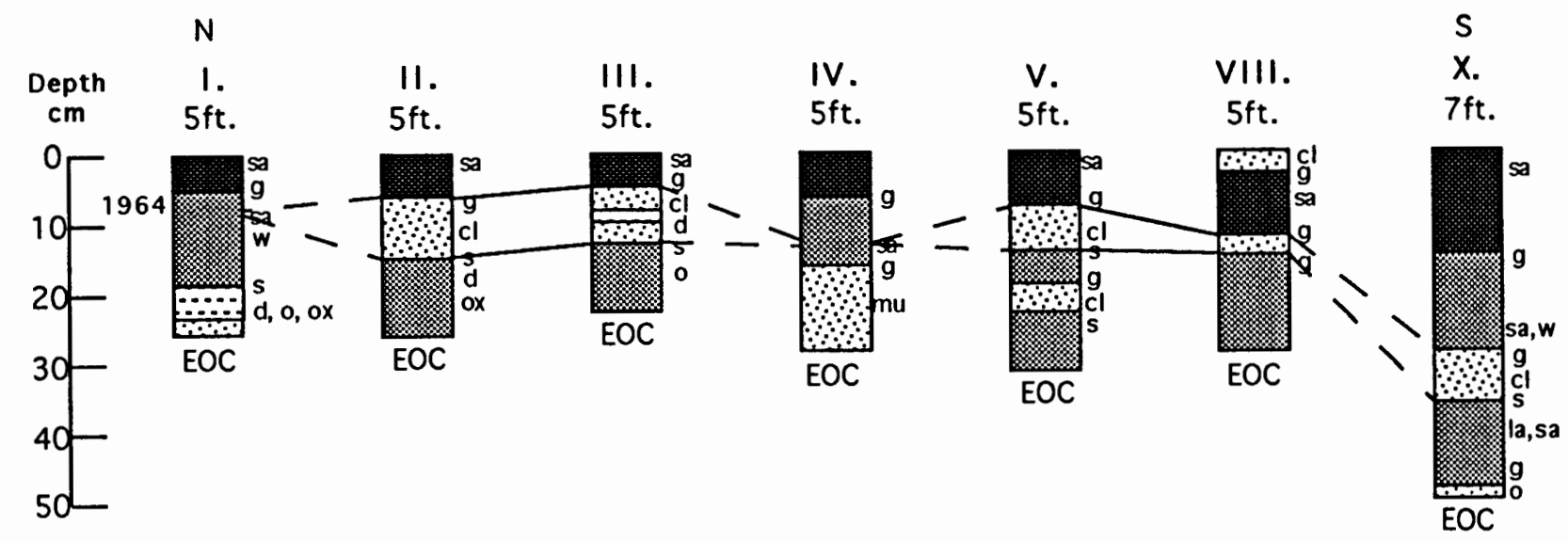

Figure 47. SSW grid cores I-V, VIII, and X. 


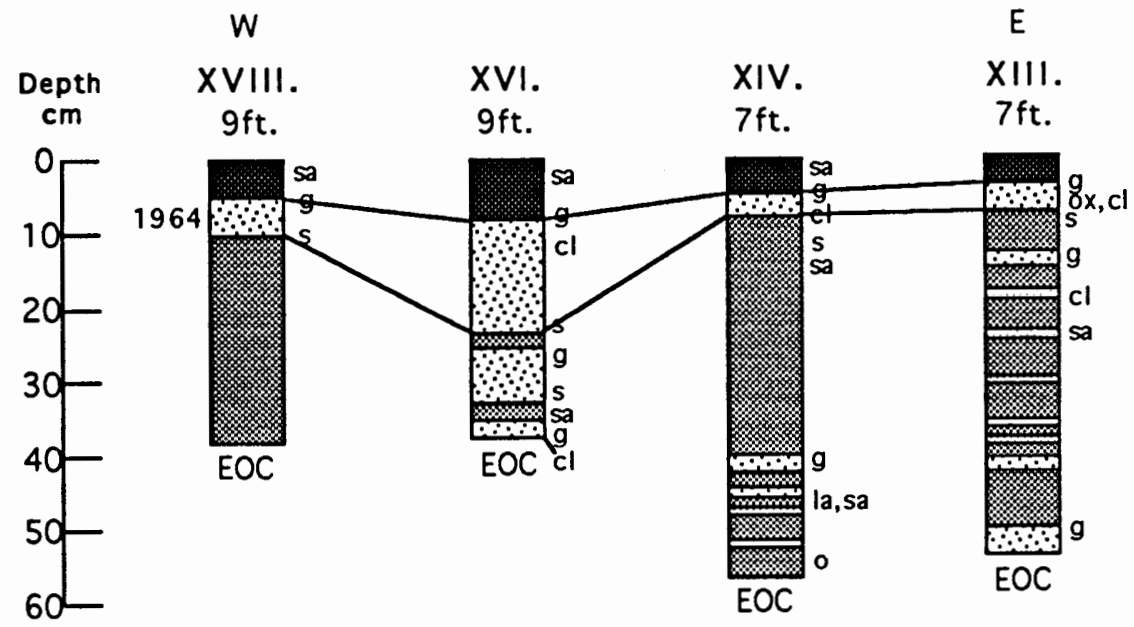

Figure 48. E-W cross-section of the central SSW grid cores XIII, XIV, XVI, and XVIII. 


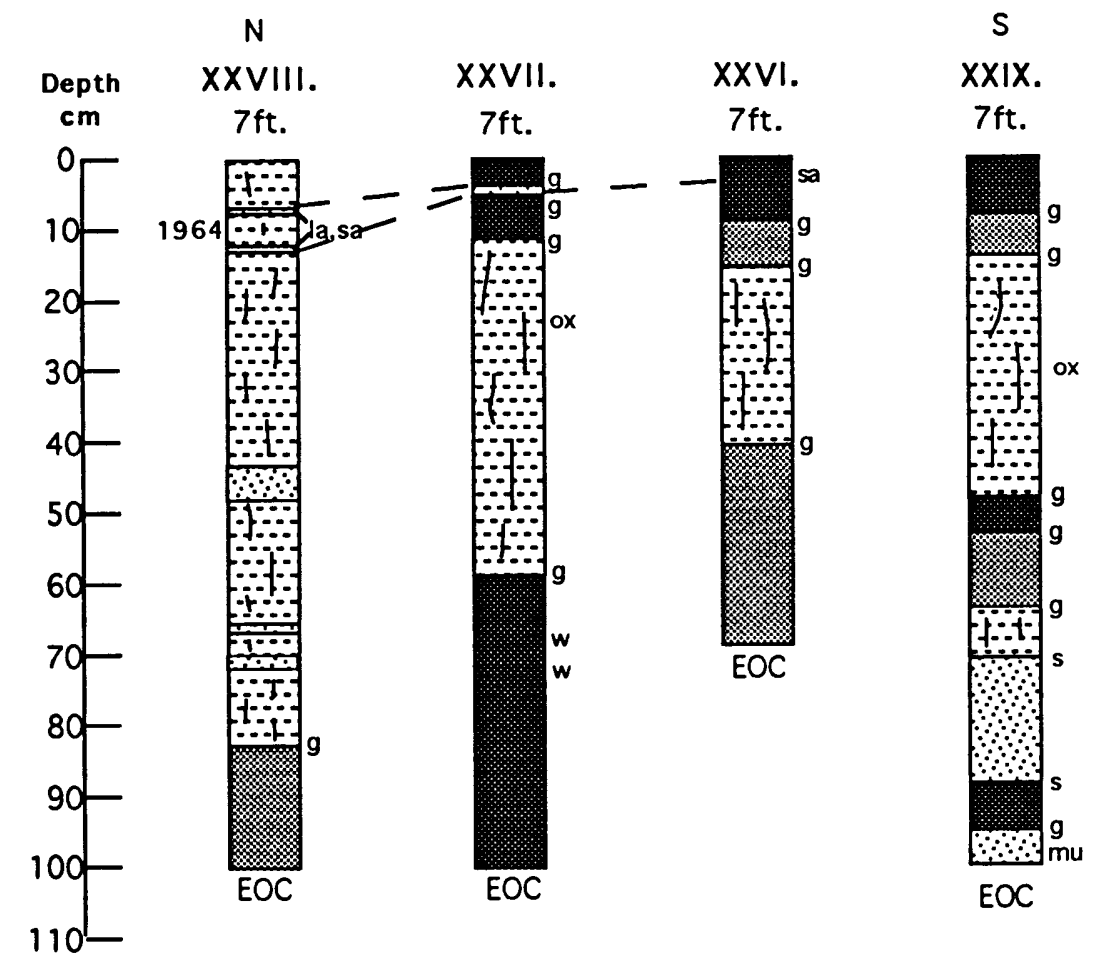

Figure 49. Southern SSW N-S grid cores XXVIII, XXVII, XXVI, and XXIX.

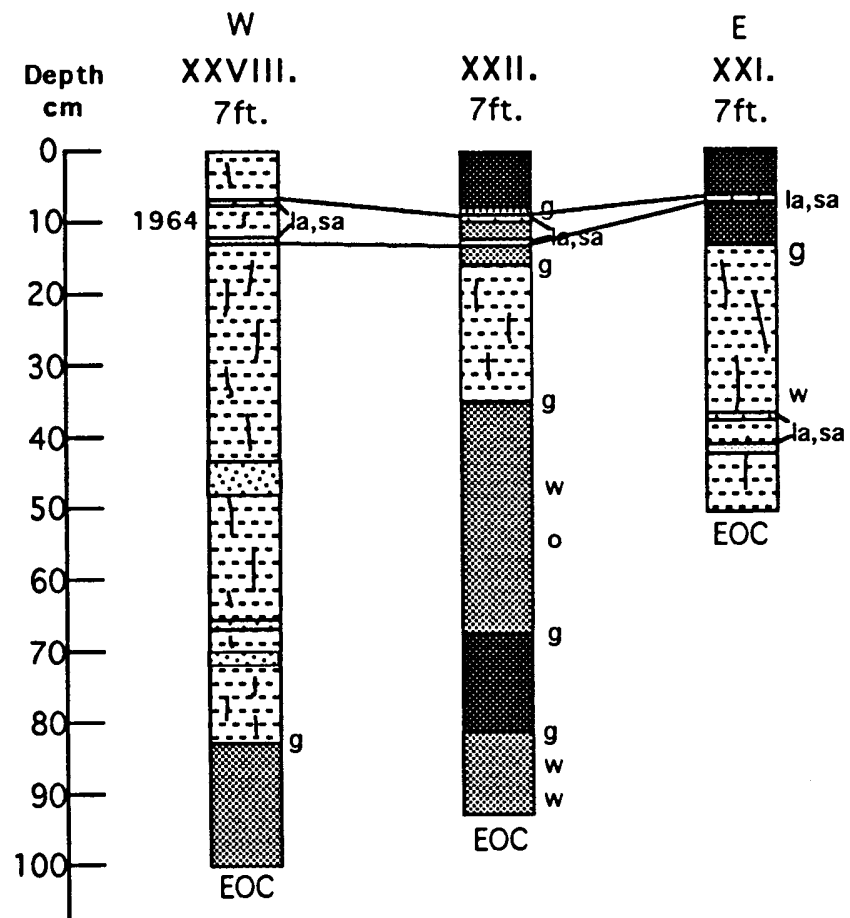

Figure 50. Southern SSW E-W grid cores XXVIII, XXII, and XXI. 


\section{Trenching}

Two trenches, SSW 1A and 1B, were dug on the point bar near the mouth of Neawanna Creek. Trench SSW 1A shows the 1964 sand layer 7-13 cm in depth with a sharp lower contact above a peaty mud (Figure 51). Above the sand is a debris cap of organic detritus at seven centimeters of $1-3 \mathrm{~cm}$ in thickness.

Trench SSW 1B contains similar stratigraphy (Figure 52) showing the 1964 sand layer in sharp contact with an underlying peaty mud. However, overlying the sand is a sandy peat layer and underlying the peaty mud is a muddy sand.

These trenches show a greater resolution of the shallow 1964 sand horizon compared to the limited view of the gouge cores. The sand layers observed in the trenches do not show evidence of internal mud laminations. Careful examination failed to confirm paleoflow directions from bent grass (flop-overs). Apparently, oxidation processes in the shallow soil decayed the plant macrofossils buried by the sand. Finally, there were no intruded contacts or fluidized features (clastic sills or dikes) observed in the trench exposures.

\section{Prehistoric Events}

The wetland shallow stratigraphy of Neawanna Creek is complex and variable over relatively short distances (10's to 100 's of meters). Only about one half of the cores record subsidence contacts and many of the core sites contain multiple sand layers with intruded contacts. The core sites are grouped into four localities for a detailed discussion below. These localities are the Necanicum estuary confluence to 
Trench SSW 1A, West Face

$7 \mathrm{ft}$.

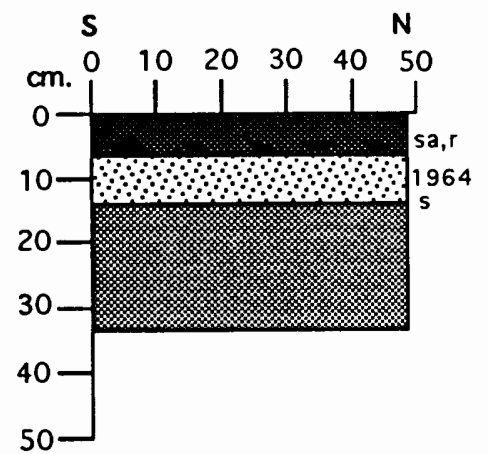

0-7 cm, sandy muddy peat (rooted), debris cap of detrital organics at $7 \mathrm{~cm}$.

7-13 cm, sand, sharp lower contact, 1964.

13-34 cm, peaty mud.
Trench SSW 1A, South Face

$7 \mathrm{ft}$.

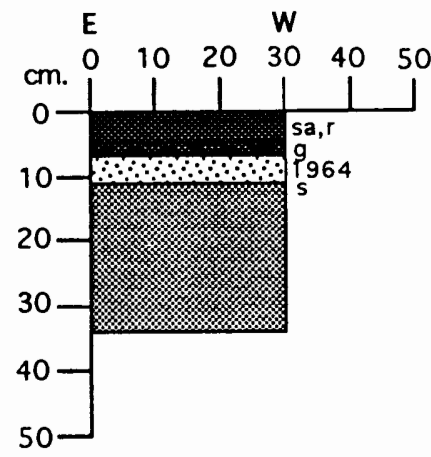

0-5 cm, sandy muddy peat (rooted), lower gradational contact.

5-7 cm, debris cap of detrital organics.

7-11 cm, sand, sharp lower contact, 1964.

$11-34 \mathrm{~cm}$, peaty mud.

Figure 51. Neawanna Creek trench 1A.

Trench SSW 1B, West Face

$7 \mathrm{ft}$.

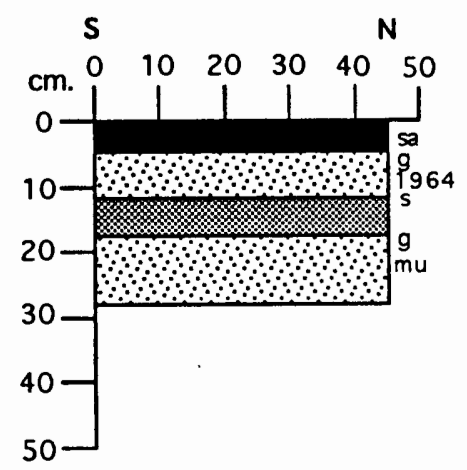

$0-5 \mathrm{~cm}$, sandy peat, slight organic cap at $5 \mathrm{~cm}$, gradational lower contact.

5-12 cm, sand, sharp lower contact, 1964.

$12-18 \mathrm{~cm}$, peaty mud, gradational lower contact.

$12-28 \mathrm{~cm}$, muddy sand, becomes sandier down section.
Trench SSW 1B, South Face

$7 \mathrm{ft}$.

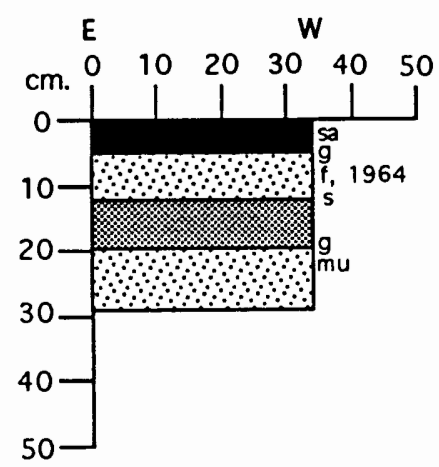

$0-5 \mathrm{~cm}$, sandy peat, gradational lower contact.

5-12 cm, sand, fining up, sharp lower contact, 1964.

$12-20 \mathrm{~cm}$, peaty mud, gradational lower contact.

$20-29 \mathrm{~cm}$, muddy sand, becomes sandier down section.

Figure 52. Neawanna Creek trench 1B. 
Avenue, 12th Avenue to south of Broadway Drive, south of Broadway Drive to S Avenue, and S Avenue to the southernmost Mill Ponds.

Neawanna Confluence to 12th Avenue (Figure 39)

Around the proximity of the 12th Avenue bridge, five cores indicate subsidence. SSW $720,716,717,714$, and 781 have a subsidence contact at roughly $77 \mathrm{~cm}$ from the surface (Figure 53). These cores have a muddy peat or peat sharply in contact with an overlying sand or rooted mud ranging from 67 to $88 \mathrm{~cm}$ depth within subsurface. The sand layer in both 716 and 717 is one centimeter in thickness. There is minor peaty mud development with an overlying thin sand layer at $56 \mathrm{~cm}$ in SSW 781.

\section{2th Avenue to south of Broadway Drive (Figure 40)}

Northeast of the Broadway Drive bridge, the core lithologies become irregular. SSW 712 has a thin mud layer between the peaty mud and the sand layer. In SSW 778 and 779 , the stratigraphy has a rooted mud with an overlying sand layer. The contacts of the sand are intruded and the lower contacts occur at 60 and $55 \mathrm{~cm}$ for SSW 778 and 779 respectively. If these intruded sands within these cores are of coseismic origin, then a younger buried peat surface (1700 AD) must lie above them (Figure 54). Evidence of paleosubsidence from the $1700 \mathrm{AD}$ event is absent from many cores in the Neawanna wetlands.

Near the Broadway Drive bridge, SSW 847, 762 and 766 show a buried horizon at 58 to $62 \mathrm{~cm}$ (Figure 55). All three cores have an overlying sand deposit (SCL) ranging from 2 to 4 centimeters thick. Site SSW 766 has a poorly developed muddy peat of only two centimeters in thickness. 
N

$S$

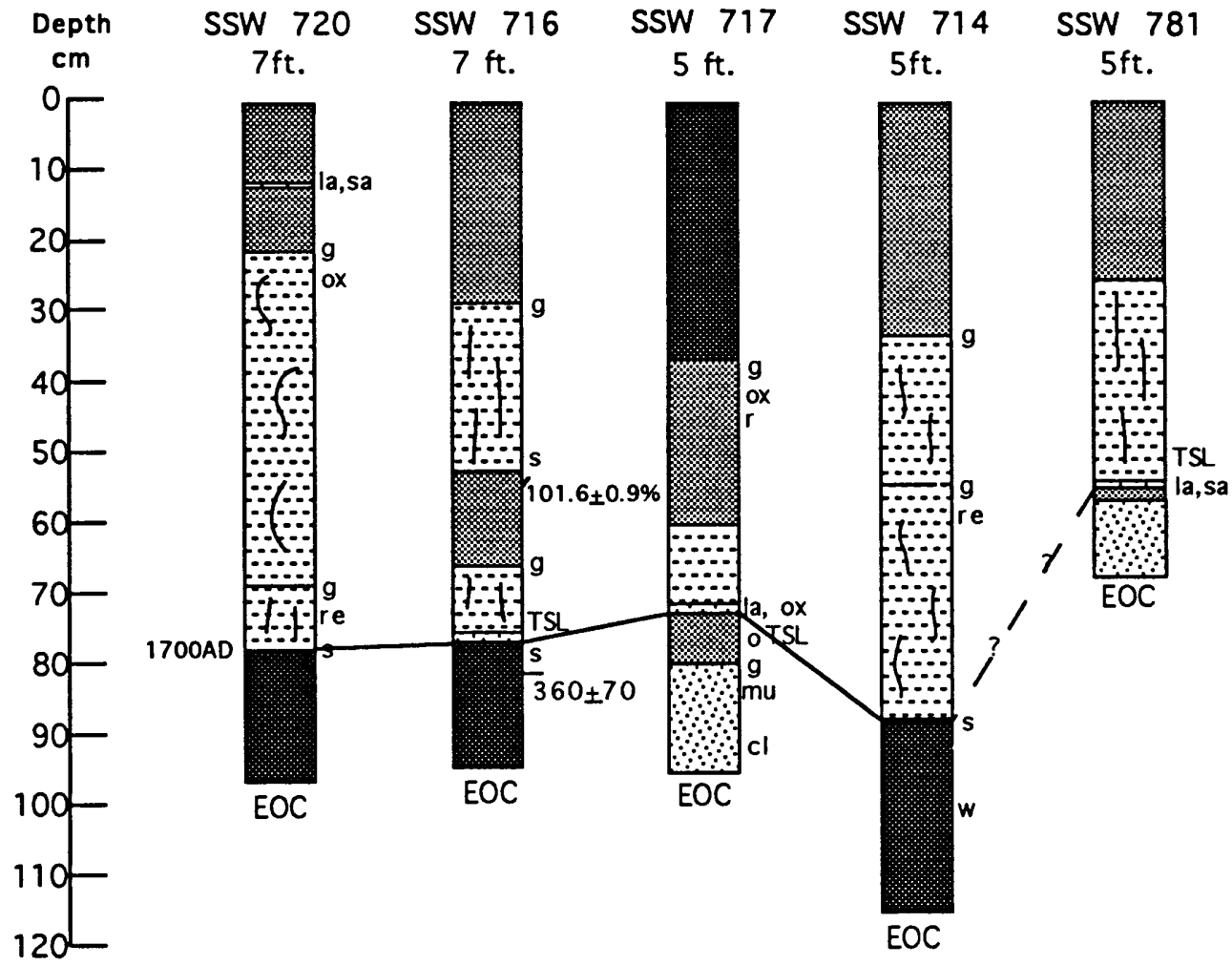

Figure 53. Neawanna Creek cores SSW 720, 716, 717, 714, and 781. 


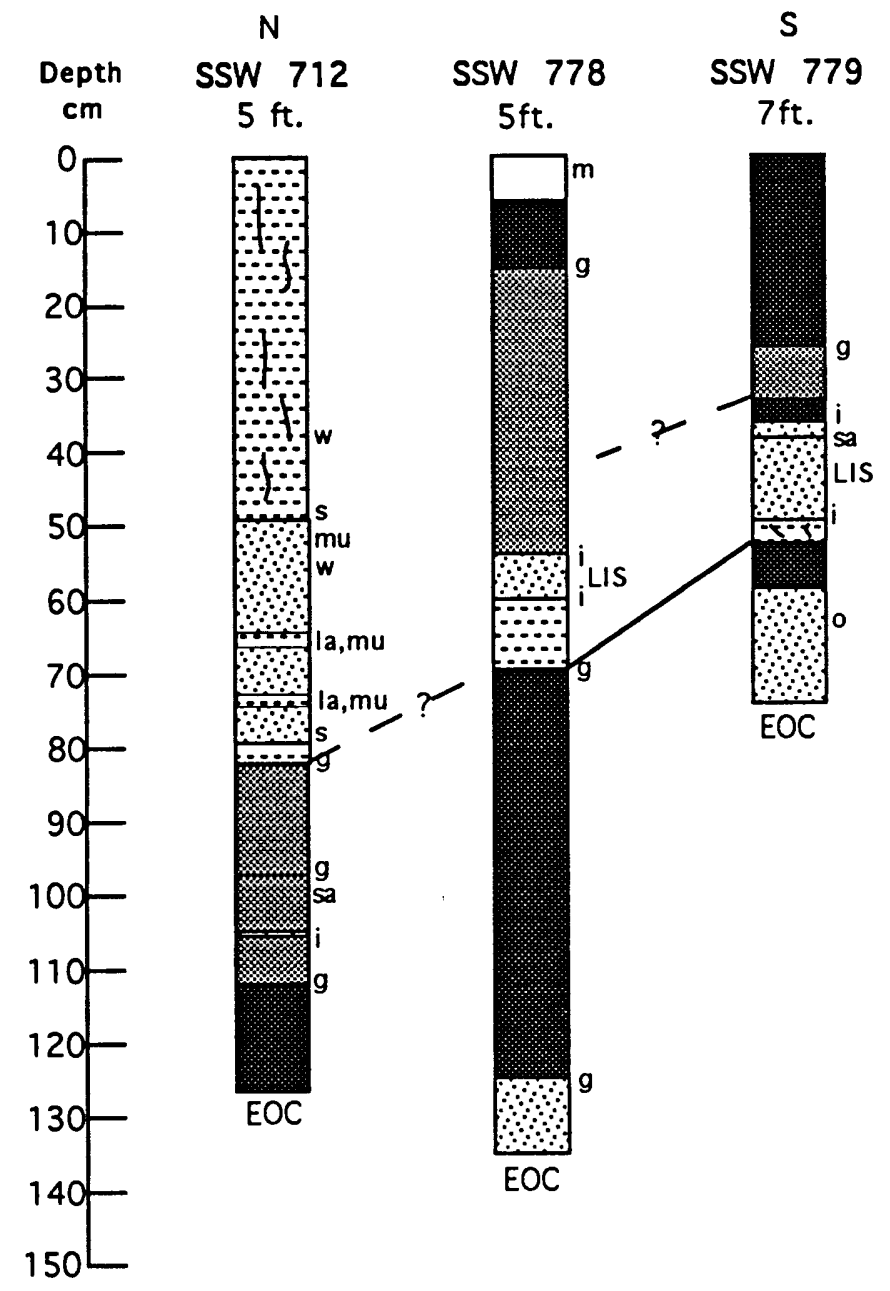

Figure 54. Neawanna Creek cores SSW 712, 778, and 779. 


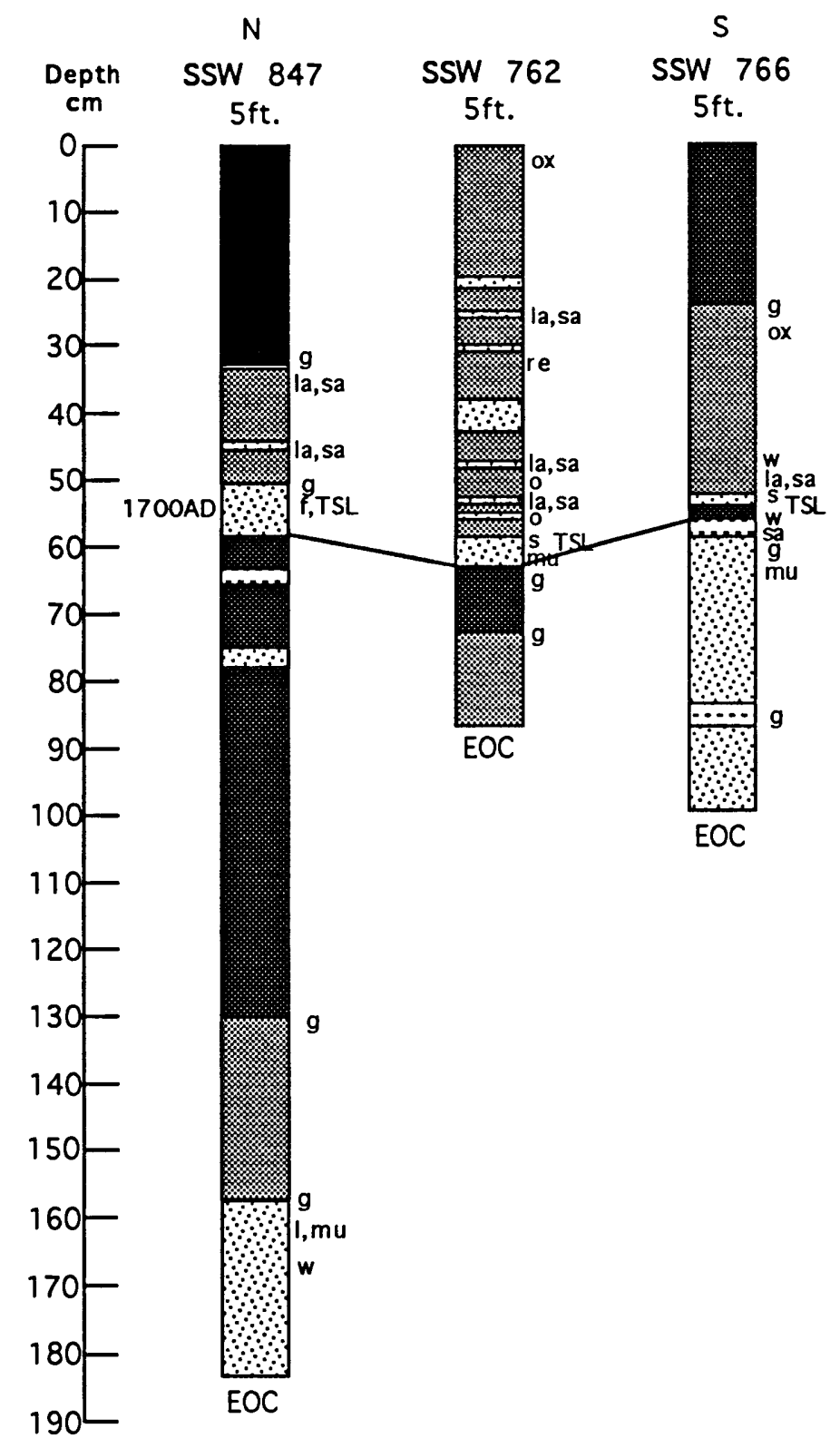

Figure 55. Neawanna Creek cores SSW 847, 762, 766. 
Broadway Drive to S Avenue (Figure 45)

Cores SSW 808, 806, 803 show a subsidence event between 50 and $70 \mathrm{~cm}$. All three have an overlying rooted mud with some sand. Site SSW 768 contains a buried muddy peat with an overlying three centimeters thick sand. Site SSW 803 also contains debris flow material at $73 \mathrm{~cm}$, which underlies a subsidence interval (Figure 56). Sites SSW 782 and 783 contain irregular stratigraphy (Figure 57). These buried layers have underlying sand deposits with intruded contacts implying liquefaction origin.

Cores SSW 823-825 contain primarily rooted mud with a peaty mud at depth (Figure 58). The peaty mud ranges in depth from 75 to $100 \mathrm{~cm}$, and it contains a thin sand layer towards the upper portion of the peaty mud. A large cobble $(10 \mathrm{~cm} \mathrm{x} 6 \mathrm{~cm}$ $\mathrm{x} 2 \mathrm{~cm}$ ) was found at $70 \mathrm{~cm}$ in SSW 823. Site SSW 824 contains a dike sand lamination which cuts through the upper portion of the peaty mud at $73 \mathrm{~cm}$.

Sites SSW 789, 788, 787, 784, 818 are found to the north of S Avenue bridge. Sites SSW 789, 788, and 787 have a muddy peat in sharp contact with the overlying sand deposits, some of which fine upward. Some of these sands are overlain by rooted mud. Subsidence was indicated at SSW 784 by a rooted mud overlying a muddy peat at $72 \mathrm{~cm}$. Core site SSW 818 contained another distinct example of a peaty mud overlain by a thin sand layer at 73 and $125 \mathrm{~cm}$. Site $\mathrm{SSW} 788$ has a sequence of muddy peat, sand, and rooted mud with a lower sand contact at $162 \mathrm{~cm}$. Cores 784, 787-789 show a subsidence event at around $50 \mathrm{~cm}$ (Figure 59). Site SSW 787 has an overlying 
W

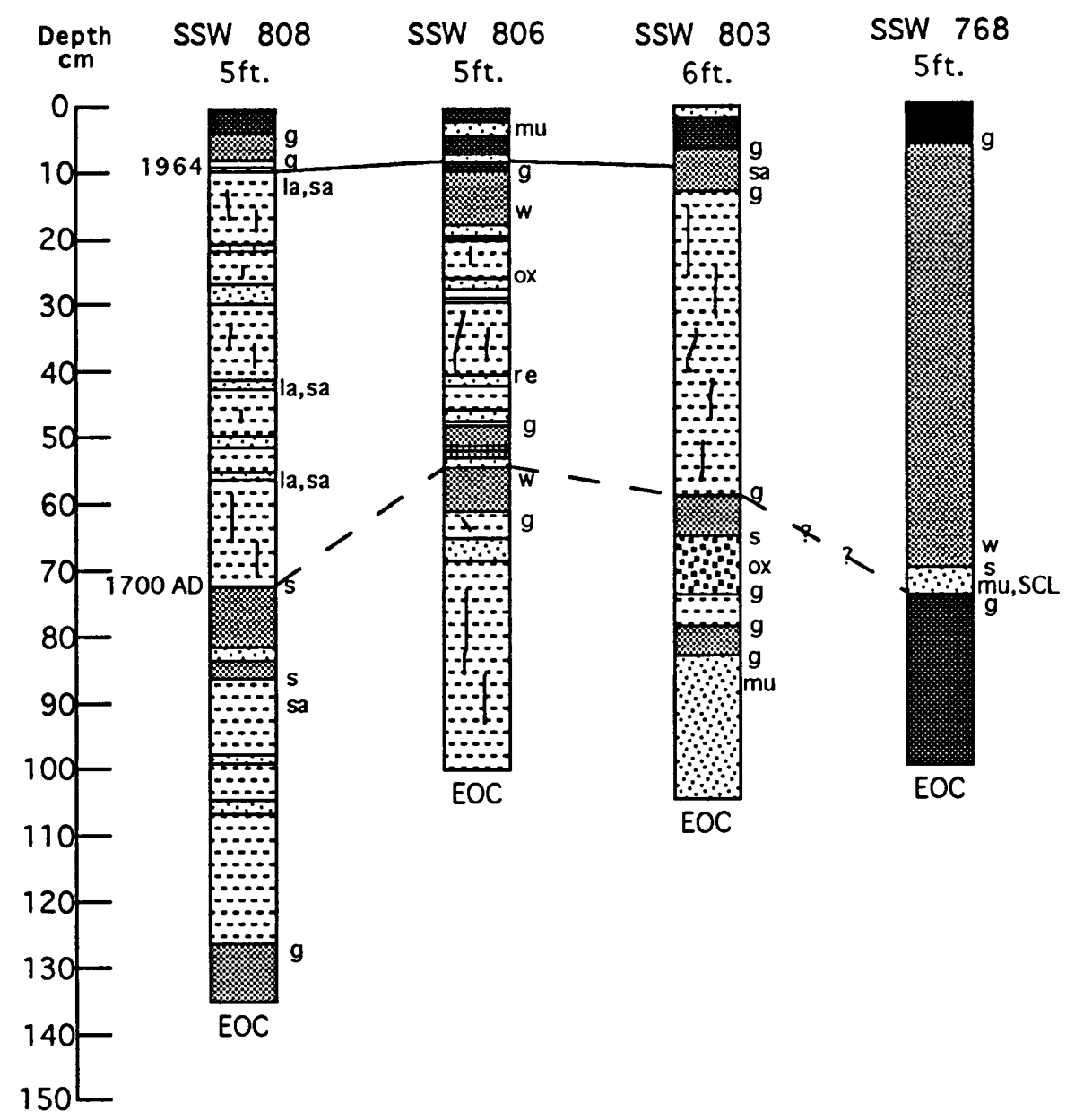

Figure 56. Neawanna Creek 808, 806, 803, and 768. 


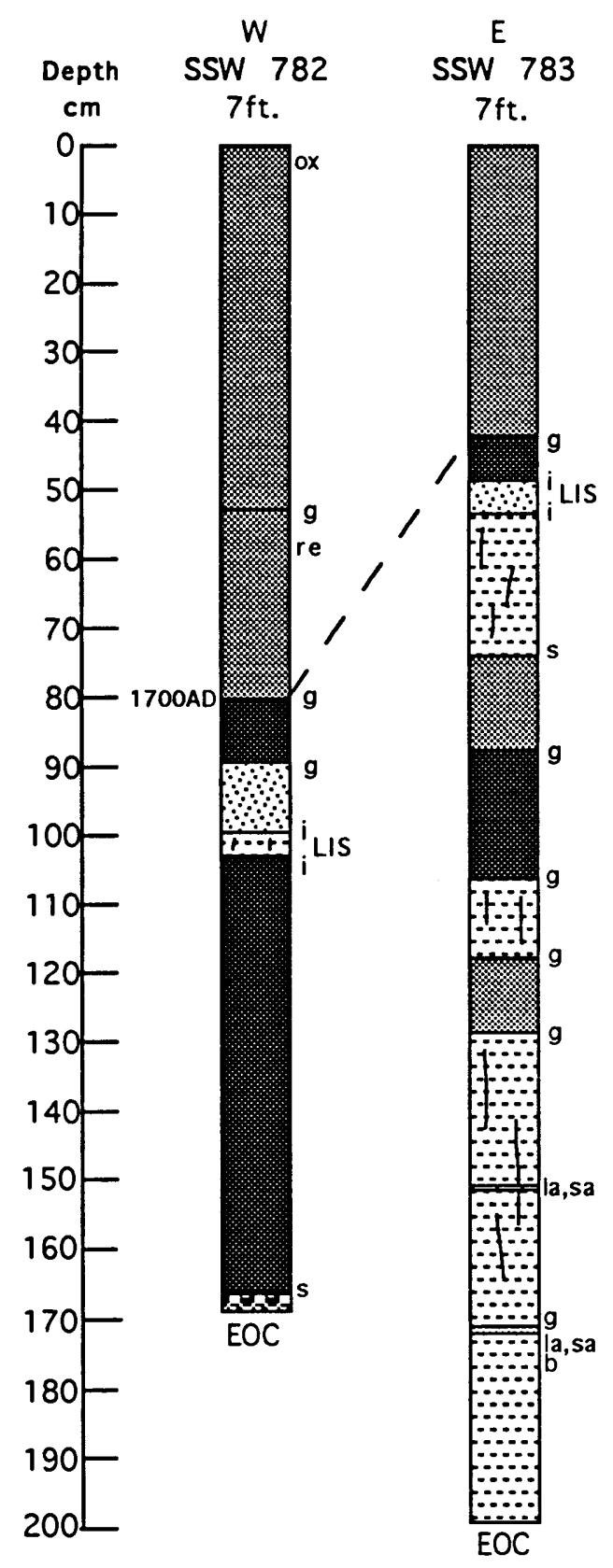

Figure 57. Neawanna Creek cores SSW 782 and 783. 


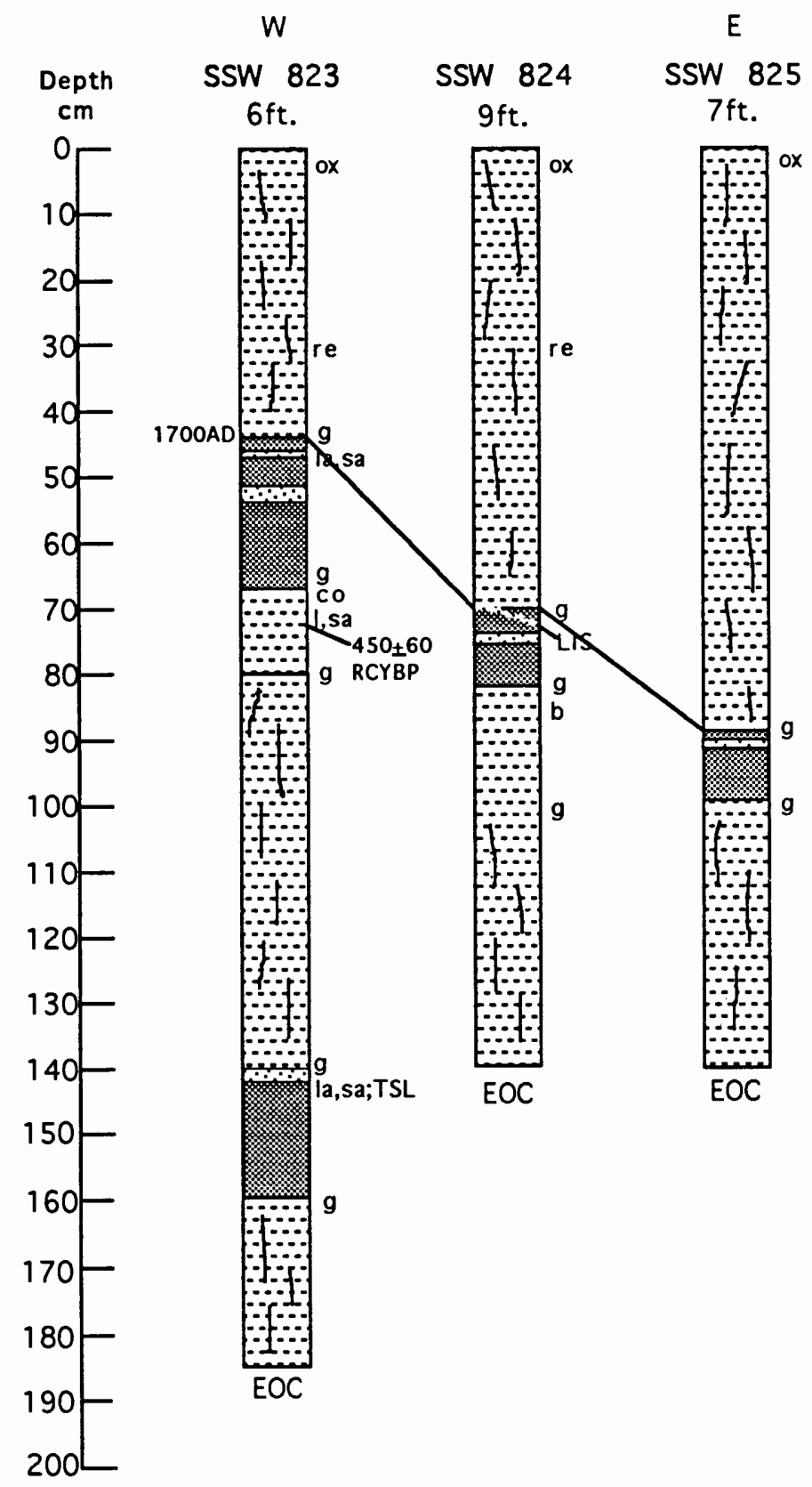

Figure 58. Neawanna Creek cores SSW 823-825. 
N

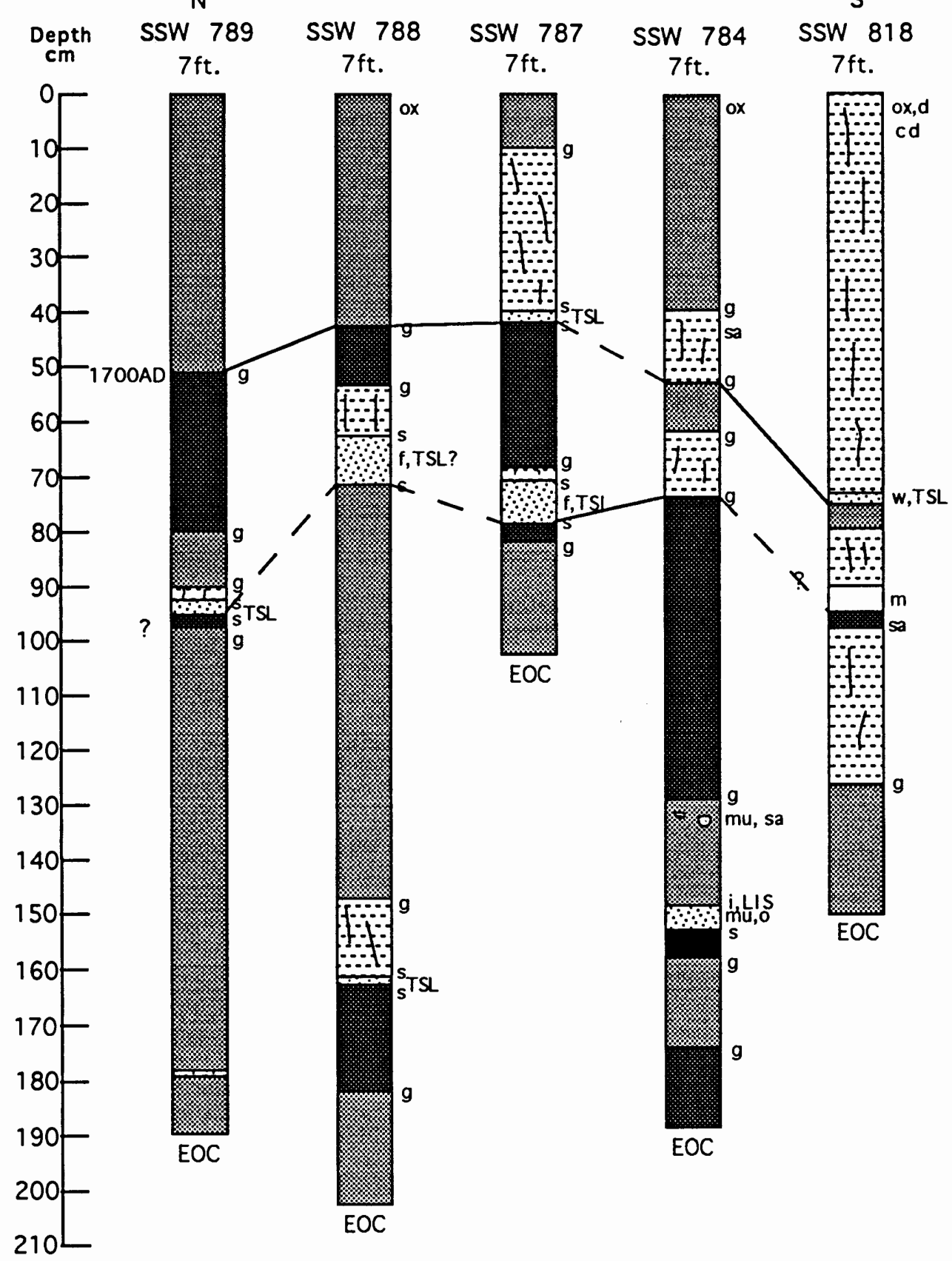

Figure 59. Neawanna Creek cores SSW 789-787, 784, and 818. 
sand layer (TSL) whereas the remaining cores do not.

S Avenue to the Mill Ponds (Figure 60)

South of S Avenue and to the west around the Mill ponds, cores SSW 735, 730, 828-832 indicate probable tsunami deposited sand layers above subsidence contacts (Figure 61). Site SSW 735 has a sand layer within a muddy peat. However, the remainder of the samples have muddy peats to peaty mud with overlying sand deposits. These sites SSW 730, 828, and 830 grade into a muddy peat above the sand layers. Sites SSW 830 and 831 have buried contacts at 130-140 cm. Both SSW 830 and 831 have a peaty mud underlying a rooted mud. Finally, SSW 828 contains several short buried intervals of peaty mud underlying a rooted mud.

\section{Radiocarbon Samples}

Five cores consisting of seven samples were taken for radiocarbon dating in the Neawanna Creek wetlands. Core site SSW 716 had a date of $360 \pm 70$ RCYBP at a depth of $81 \mathrm{~cm}$. This wood sample was collected just below the sand/muddy peat contact which occurs at $78 \mathrm{~cm}$. Another wood sample was collected at $84 \mathrm{~cm}$ just below a sand lamination within mud in core SSW 823. Because a buried peat does not underlie the sand lamination, subsidence is not associated with this particular contact. A date of $450 \pm 60$ RCYBP was derived from this horizon. A fairly young date $(190 \pm 50$ RCYBP) was obtained for a spruce cone obtained at $84 \mathrm{~cm}$ in SSW 729. This sample was taken from a muddy peat below a sand layer. Additional wood fragments were collected at $83 \mathrm{~cm}$ in SSW 831. A date of $620 \pm 40$ RCYBP was returned. Finally, in 


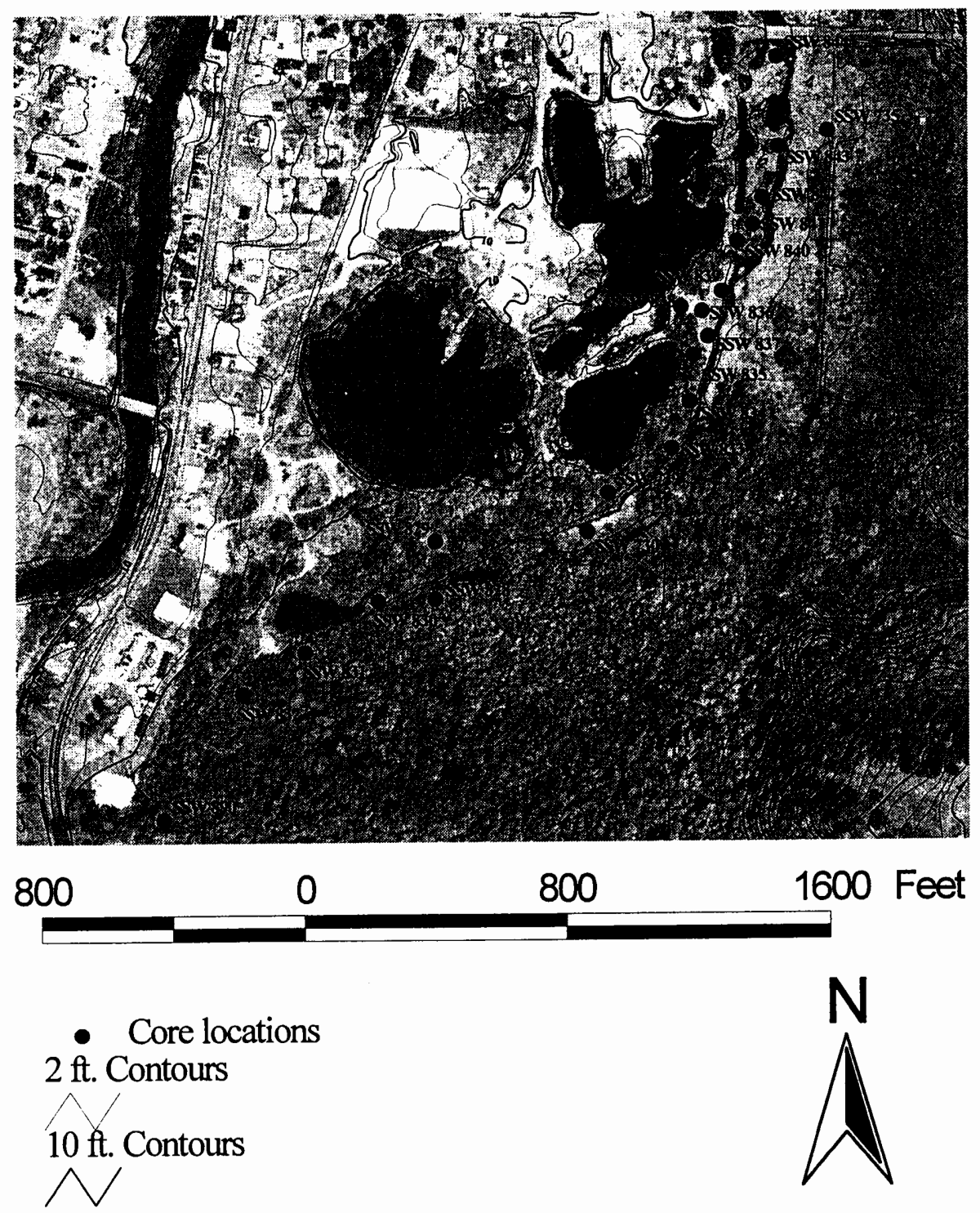

Figure 60. Neawanna Creek observation sites and core locations from S Ave. to the Mill Ponds. 


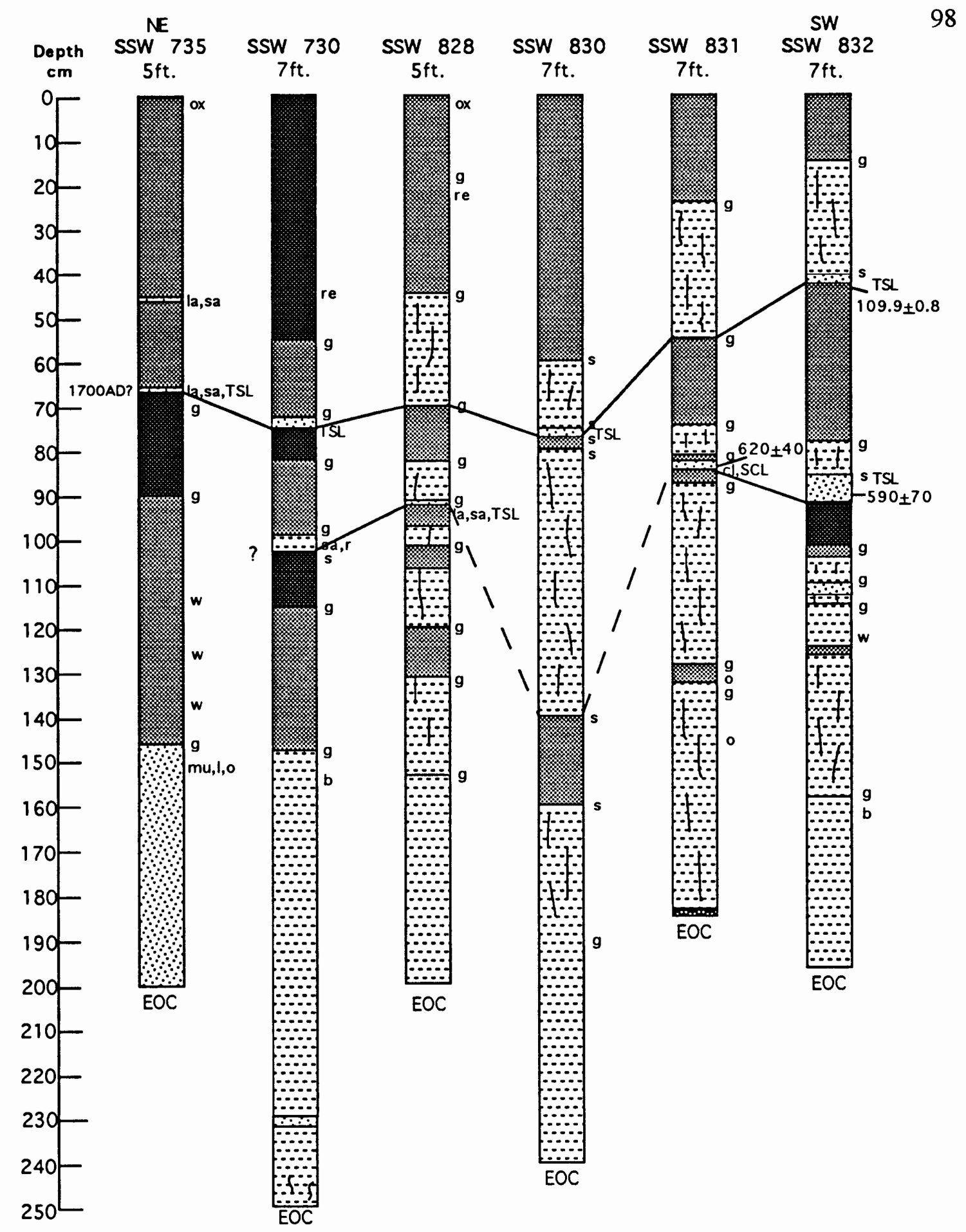

Figure 61. Neawanna Creek cores SSW 735, 730, 828, 830, 831, 832. 
SSW 832, wood fragments were dated at both 43 and $90 \mathrm{~cm}$. Dates returned were $109.9 \pm 0.8 \%$ and $590 \pm 70 \mathrm{RCYBP}$.

Sites SSW 729, 831, and 832 at the lower Neawanna Creek near the Mill Ponds contained extensive modern root contamination throughout the intervals sampled for radiocarbon ages. At sites SSW 831 and 832 wood sticks (roots?) were sampled from below the contact between the sand and buried peat. The true relationship of the wood sample (e.g. detrital or descending roots) with the horizon containing it was difficult to establish. These radiocarbon dates could have been contaminated by young carbon from descending roots. Obvious detrital fragments such as pine cones or seed pods were not observed in the returned cores.

\section{Diatom Analysis}

SSW 831 was analyzed for a change in diatom presence above and below the contact at $83 \mathrm{~cm}$. Sample SSW 831 at $84 \mathrm{~cm}$ indicated a dominance of fresh to slightly brackish diatoms. Eunotia petinalis, Gomphonema augustat, and Gomphonema parvulum were the abundant species in this lower interval. However, in the interval above the contact $(82 \mathrm{~cm})$ the diatom presence changed to a brackish/marine influence, shown by Pinnularia virdis and Biddulphia dubia, with considerable reduction in the amount of the freshwater diatoms. This influence of marine to brackish diatoms above a peat horizon containing mainly freshwater to brackish diatoms supports the evidence that this contact represents a subsidence event. This youngest apparent subsidence contact is assumed to represent the last Cascadia earthquake event at $1700 \mathrm{AD}$. 


\section{Seaside Paleogeography}

In order to help constrain the paleogeography of the Seaside tidal systems and associated wetlands, the intervening cobble ridges were mapped and some ridges were profiled with ground penetrating radar (GPR).

\section{Cobble Ridge Mapping}

The cobble ridges throughout Seaside trend roughly $\mathrm{N} 10^{\circ} \mathrm{E}$ (Figure 62). The basaltic cobbles originate from Tillamook Head and extensively cover the southern portion of Seaside in the areas of the cove, Avenue $U$, and the Seaside Golf Course. Toward the north, the ridges taper and are covered by greater dune sand thickness. The Necanicum River has patchy cobble ridge evidence to the north on both sides of the river. There is also an increased amount of sand. On the east side of the Necanicum River, a cobble ridge extends from near Indian Way south to Broadway Drive. The western portion of the Necanicum River is densely packed with cobbles. This occurs from Broadway Drive all the way to the cove and Avenue U. In the area to the south, cobbles are evident on the beach. Seaside Golf Course is also built on some of these cobble ridges.

Cobble ridge mapping in the Neacoxie Creek area shows evidence that the eastern boundary of Neacoxie Creek is bounded by a gravel ridge with overlying dune deposits. Walking along the east bank of Neacoxie Creek toward the mouth, the cobbles become evident. 


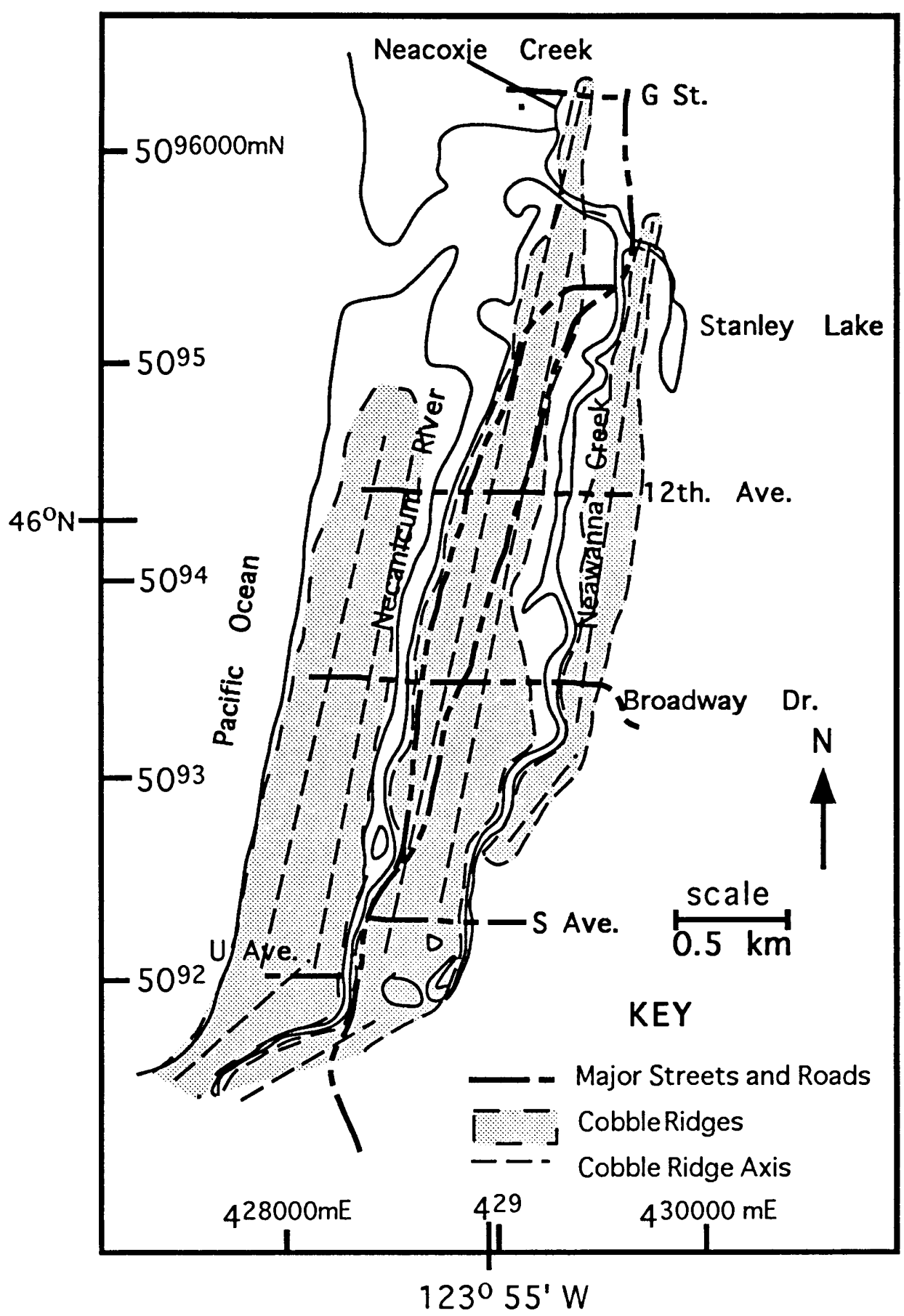

Figure 62. Locations of cobble ridges extending throughout Seaside. 
The western boundary of Stanley Lake is composed of a cobble ridge which is evident both in cores and the local surfaces.

Neawanna Creek has patchy evidence of cobble ridges on the east side. Areas composed of cobbles lie along Wahanna Road running parallel to Neawanna Creek on the east side primarily between Mill Creek Road (near HWY. 101) and Broadway Drive. There is also a patch near Neawanna Creek across from the Wahanna Road baseball fields. On the western side of Neawanna Creek, a rather extensive, dense cobble ridge runs from just north of Broadway Drive south to the Mill Ponds and Avenue U.

\section{Ground Penetrating Radar}

The High School athletic practice fields at the northern portion of Seaside were used to run three GPR lines. One continuous line (1r1) ran S-N along the length of the football field (Plate 1). The E-W line (1c1) was split into two sections. One originated west of the football field near the pole vault pit extending toward the tennis courts and eventually crossing HWY. 101 (Plate 2). The second line originated at the beginning of the S-N line and ran west extending to Necanicum Drive and to the east bank of the Necanicum River (Plate 3).

Both the N-S and E-W GPR profiles show relatively horizontal beds and a shallow reflection indicating the freshwater table. This $206 \mathrm{~m} \mathrm{S-N} \mathrm{GPR} \mathrm{profile} \mathrm{showed}$ relatively horizontal layers down to roughly $13 \mathrm{~m}$. The lack of channel cut and fill 
structures argues against E-W channelization in this area in late prehistoric times. The two E-W GPR profiles also indicate relatively horizontal layers down to $15 \mathrm{~m}$.

These profiles at Seaside High School do not show cut and fill channel features either parallel or normal to the present cobble ridge axis. The basal cobble ridge near present sea level apparently built northward, constraining the Neawanna flow to the east. A thick sand cap $(5+\mathrm{m})$ on top of the basal cobbles required a direct connection to dune fields to the west, southwest, and/or the northwest. This indicates that the Necanicum mouth was located to the south of its present position in late prehistoric time. Northward migration of the Necanicum mouth to its present position, and subsequent breaching of the N-S cobble/dune ridge (that extends N-S of Seaside High School) permitted the development of a confluence between the Neawanna and the Necanicum near its present location. The lack of wetland stratigraphic layers older than the $1700 \mathrm{AD}$ subsidence event at the northern end of the Neawanna argue that the confluence of these two tidal systems at the present location is a relatively recent development (probably less than $1 \mathrm{Ka}$ ). A recent northward migration of the Necanicum mouth would also explain the lack of prehistoric wetland stratigraphy along its northern banks and the lack of prehistoric buried wetlands in the Neacoxie Creek immediately to the north.

The Seaside golf course first fairway provided a locality to examine the cobble ridges originating from Tillamook Head. One N-S line (100c) ran the length of the fairway-cobble ridge (Plate 4). The two E-W profiles 100 meters apart (100a and 
100b) dissected the N-S profile (Plates 5 and 6). The $100 \mathrm{~m} \mathrm{~N}-\mathrm{S}$ profile shows inclined reflections prograding from south to north. These layers extend to about ten meters below the present surface. The E-W profiles $100 \mathrm{a}$ and $100 \mathrm{~b}$ cover 141 and $123 \mathrm{~m}$ respectively, and they indicate relatively horizontal layers to about ten meters in depth. However, farther to the west, the layers become inclined toward the ocean (westward). Jol and others (1996) ran a radar line along an E-W profile which is located at the north end of the Tides Motel on Avenue $U$ and ends at the promenade. This profile showed an inclined cobble strata dipping west at angles of up to $23^{\circ}$ to a depth of $11 \mathrm{~m}$. They interpreted this as being a paleobeach surface possibly deposited during storm events, providing supporting evidence for westward progradation of the beach cobble ridge.

\section{Summary}

The Seaside wetlands represent N-S valleys constrained between beach cobble ridges. The southern reaches of the Neawanna Creek and the Necanicum River have been separated from each other for at least the last several hundred years (prior to the $1700 \mathrm{AD}$ event). Northward migration of the Necanicum mouth to its present position and confluence with the Neawanna and Neacoxie Creeks in their present geometry apparently occurred only relatively recently (possibly just before or after the $1700 \mathrm{AD}$ event). 


\section{Discussion}

This study aids in evaluating the potential hazards of nearfield tsunami inundation in the Seaside area from the geological record of prehistoric Cascadia tsunami deposits within the surrounding coastal wetlands. This discussion section first identifies areas affected by amplification and attenuation for the 1964 farfield tsunami in Seaside based on historic records. Then prehistoric geomorphology of the Necanicum estuary system and the geologic records of coseismic subsidence, liquefaction, and nearfield tsunami inundation in Seaside are interpreted.

\section{Event}

Surge hydrodynamics of the 1964 tsunami prior to entering the Seaside beach or Necanicum estuary aids in determining the strength of the wave and possible height upon reaching shore. Although a considerable amount of damage occurred at Seaside, little specific wave information is available. The two closest recordings were taken at Astoria, Oregon (A), and Crescent City, California (CC), and the information provided here will reflect those ranges (Lander and others, 1993). At the time of inundation ( $\mathrm{A}=$ 11:56 PM PST; $C C=11: 54$ PM PST), high tide was just receding. The period of the waves ranged from 29.0 to 20.0 minutes for Crescent City and Astoria, respectively. The maximum wave amplitude for Seaside was not instrumentally recorded. In Astoria the wave height was $0.4 \mathrm{~m}(1.3 \mathrm{ft}$.) and in Crescent City the wave height was $4.8 \mathrm{~m}$ (15.7 ft.) (Lander and others, 1993). In Seaside, there was no prior warning, some people woke with water under their beds. Word did reach the local sheriff, who tried 
to evacuate people, but there was not enough time to notify everyone (Lander and others, 1993). Waterfront residents were awaked by surge noises. Evacuation occurred at night (in the dark) with no preparation.

Historic 1964 Tsunami Surges in Seaside Tidal Creeks

Observations of the 1964 historic tsunami runup and associated deposits in Seaside provide a unique analog to help interpret prehistoric tsunami inundation from geologic records in the immediate areas.

\section{Amplification}

Reported observations of the 1964 tsunami runup in Seaside indicate that local amplification occurred in the Necanicum estuary (Venice Park), immediately south of the Necanicum River mouth, south of the G Street bridge crossing Neacoxie Creek, and south of the HWY. 101 bridge crossing Neawanna Creek (point bar) (Figure 63). The inundated elevation of Venice Park ranges from 0-4.3 m (0-14 ft.), with the majority of the home sites at about $2.4 \mathrm{~m}(8 \mathrm{ft}$.$) . Runup of 4.1 \mathrm{~m}(13.5 \mathrm{ft}),. 2 \mathrm{~m}(6.5$ ft.) above present ground elevation, was measured at SSN 684. The powerful surge(s) entered the estuary and encountered the Venice Park cobble-dune barrier. Runup over the western side of the barrier caused damage to residences on the barrier ridge. The surge(s) diverged with one component heading up the Necanicum River and the other traveling east towards the Neawanna confluence. Some local amplification might have occurred in the northern part of the Necanicum River (Figure 63) where high runup elevation and flooding debris caused damage to the 12th Avenue bridge (SSN 666). 


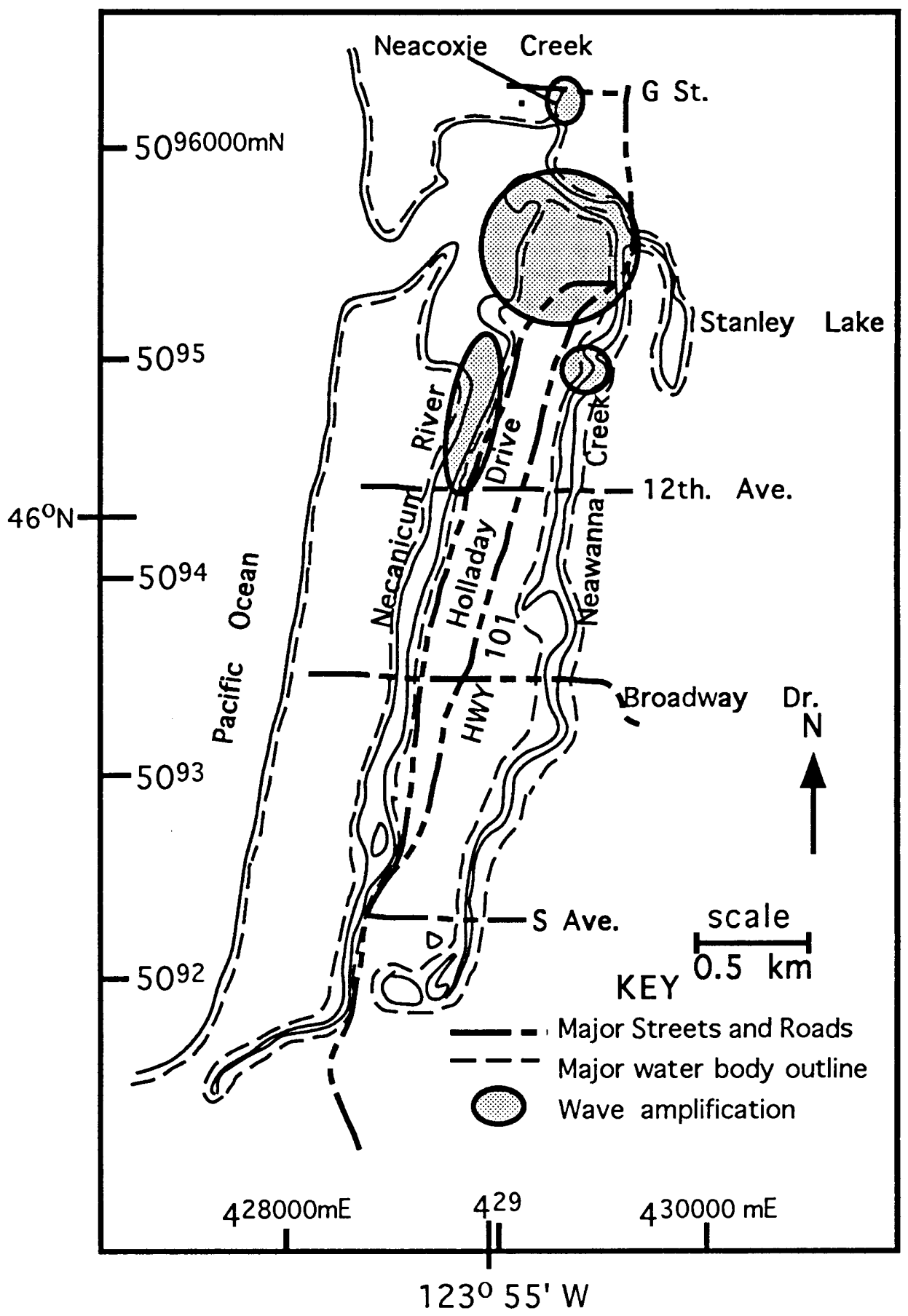

Figure 63. Areas in Seaside affected by wave amplification during the 1964 tsunami. 
The surge(s) generally attenuated with increasing distance up the Necanicum River.

Water backed up in the bay area between the Necanicum and Neawanna confluence causing extensive flooding along the northern side of Venice Park (Figure 29 and Figure 63). Runup elevations in excess of 3-4.6 m (10-15 ft.) caused damage to houses and vehicles. Fish (unknown kind) were deposited in a field, to the north of Seaside High School (SSW 705).

A substantial surge propagated up the Neacoxie Creek channel and was greatly slowed by G Street. The elevation of the marsh area surrounding the creek ranges from 0-3 m, and all observation sites but one (SSX 649, $4 \mathrm{~m}$ ) are located within this elevation range. Water levels observed were $0.3-1.1 \mathrm{~m}(1-3.5 \mathrm{ft}$.$) above the present$ surface elevation. Reported observation sites indicate that a considerable amount of debris and drift logs clogged the culvert. Debris deposits on the road pavement (SSX 650 and 651), provide evidence that the road fill slowed the surge enough to deposit sand and logs. Flooding occurred on the western banks (SSX 647, 648, and 652) 1) due to the high dune/cobble ridge on the eastern bank of Neacoxie Creek and 2) the water backing up due to the clogged culvert at G Street. A water mark observation site (SSX 646) up the creek north of G Street indicated a smaller surge surpassing the bridge and continuing up the creek, but no sand deposits were identified north of G Street.

Amplification in the eastern portion of the Necanicum estuary is demonstrated by runup of about 4-4.6 $\mathrm{m}(13-15 \mathrm{ft})$. in the vicinity of the 101 bridge (SSN 697-699). A 
sharp bend and narrowing of the Neawanna confluence together with debris jamming at the HWY. 101 bridge are probably responsible for the amplification in the eastern part of the bay.

With one exception, the surge(s) generally attenuated with increasing distance up the Neawanna tidal channel. The exception is a sharp meander bend in the Neawanna channel located just upstream of the HWY. 101 bridge (Figure 39). At this site, a remnant of the cobble ridge projecting west from the Neawanna Creek east bank, caused significant flow deflection onto the west bank of the Neawanna Creek. The tsunami surge(s) eroded about one third of the projection (J. Spillman, Personal communication, 1996).

A point bar on Neawanna Creek just south of the meander bend was flooded by a prolonged surge yielding standing waves. The eye-witness located on the east bank opposite of the point bar, evacuated within minutes of the onset of the first prolonged surge. No further observations were made after that time.

\section{Surge Attenuation in the Tidal Creeks}

Observation sites up the channelized creeks document tsunami flooding for distances of 4.0 and $1.5 . \mathrm{km}$ up the Necanicum and Neawanna channels, respectively (SSG 654 and SSW 707) (Figure 64). The narrow valleys are controlled by the underlying cobble ridges that restrict lateral movement of the creeks and result in channelized flow. However, wider floodplain wetlands on the sides of the channels that accommodated some water volume, enabled surges to attenuate along these channel areas. Flooding and debris were noted all along the Necanicum River wetlands to the 


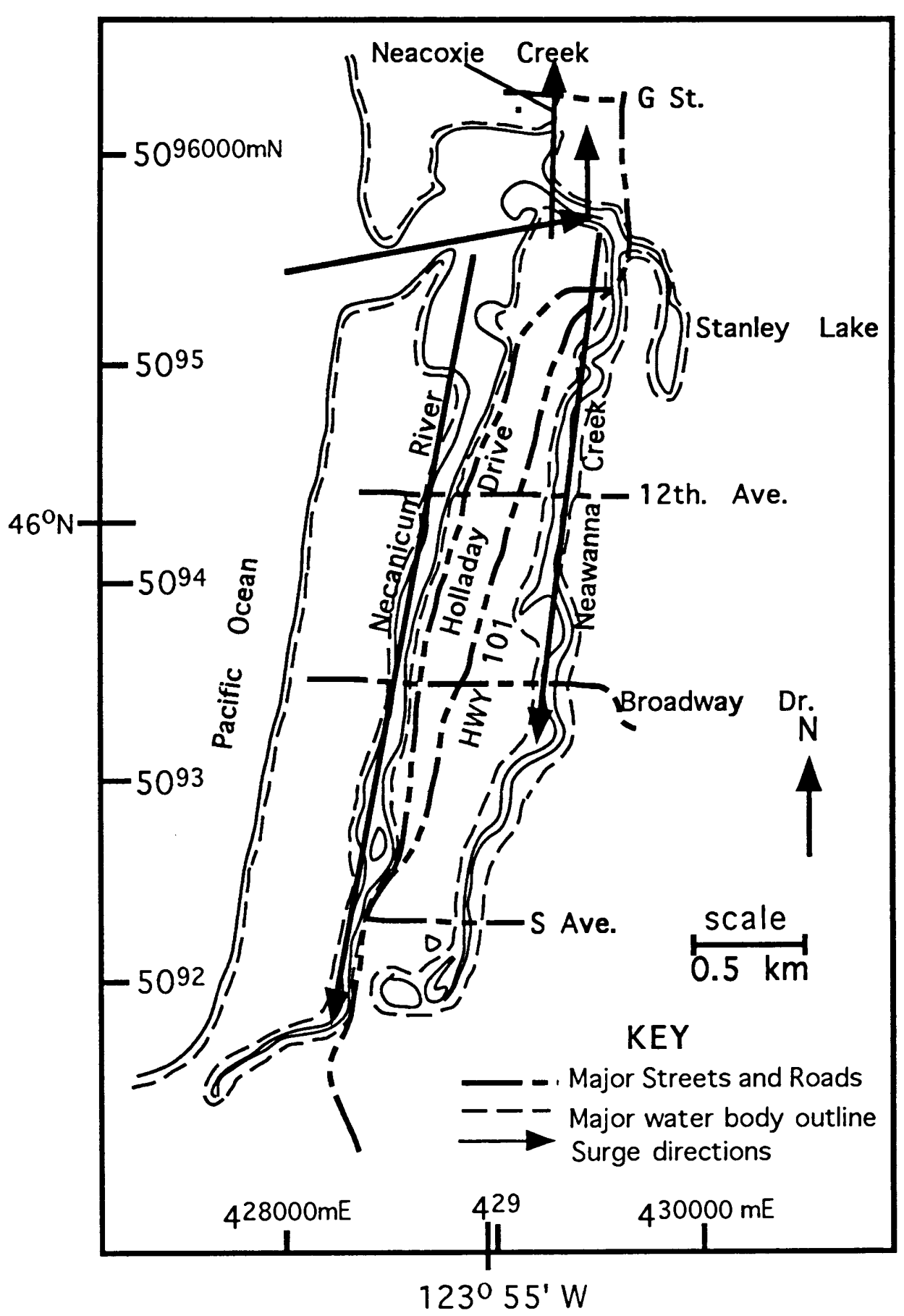

Figure 64. Seaside wetlands affected by tsunami attenuation during the 1964 event. Arrows indicate distance of flooding up river. 
Seaside golf course (SSN 663; SSG 653 and 654). Site SSG 653 indicates two water marks two feet apart, possibly indicating two surges up the Necanicum River. Many of the bridges crossing the Necanicum River recorded surge levels by structural damage, debris, and sand deposition (SSN 666, 660). Residents along the lower Neawanna Creek observed water levels flush with their yards (SSX 700 and 701, 3 m). However, no reported flooding was observed south of the 12th Avenue bridge along the Neawanna Creek banks (SSW 708-711).

Historic 1964 Tsunami Deposits in Seaside Tidal Creek Wetlands Deposit Characteristics

The geologic record for the 1964 farfield tsunami inundation in Seaside is based on well preserved, shallow sand deposits on the wetland creek banks. These shallow sand deposits are contained within muddy or peaty layers, that extend to the modern surface. The anomalous sand layers thin with distance upstream, evidence for surge attenuation and/or dilution for example, progressive loss of suspended sand. Changing lithologic composition of the sand from rounded quartz-rich beach sand to angular lithic-rich river sand was found to occur with distance up the Necanicum River. Sands from the river channel are incorporated with the wave as it surges forward, and then they are redeposited up channel as the wave loses speed with increasing distance from the bay mouth. There was no evidence for coseismic liquefaction being produced in either the 1964 sand layer or in sandy muds immediately below the 1964 sand layers. 
The 1964 tsunami sand deposits generally had lower sharp and upper gradational contacts with host deposits of peaty mud.

Some exceptions to these upriver, thinning sand sheets exist. For example, the tsunami sand deposits thicken anomalously at areas where obstructions are present such as at clogged culverts and point bars. These obstructions greatly reduce the surge velocity and cause the wave to drop some of its suspended sand load. Dammed water occurred at G Street crossing Neacoxie Creek. This occurrence created sand deposits up to $10 \mathrm{~cm}$ thick which are significantly thicker than the adjacent (mouthward) deposits associated with gradual surge attenuation up the channel.

Thick tsunami sand deposits occur $(25 \mathrm{~cm}$ thick at SSX XI) near the mouth of the Neacoxie Creek east bank. These deposits were probably produced by the incoming wave crashing into the dune/cobble ridge and depositing some of its load. Part of the surge continued up the channel and hit G Street where the remainder of the load was deposited.

South of Neawanna Creek from the HWY. 101 bridge, a prominent point bar slowed the surge resulting in tsunami sand deposits of 8-12 cm thick (SSW XV and XVI). To the immediate south of this point bar, the sand deposits thin considerably (SSW 718-719; XI-XXX; $<5 \mathrm{~cm}$ ) indicating that channel sand resuspension and deposition fell below critical values necessary to leave distinctive tsunami sand sheet deposits. 


\section{Multiple Surges}

Core and trench sites of the Necanicum River, Neacoxie Creek, and Neawanna Creek include evidence for deposition of multiple, thin, shallow sand layers separated by mud laminae (SSN 747, SSX 771-774, SSW 723, XXII and XXVIII). These deposits of alternating sand and mud (MSL) probably reflect multiple surge deposits. An explanation for such sequences is as follows: the first surge rolls in and deposits its load, and then mud settles out on top of the sand before a second surge occurs to deposit its suspended load. The process repeats for several surges. However, these deposits in Seaside are contained within only a few cores and are not continuous over local areas. It is not known whether the depositional surges correspond to time variable fluctuations of velocity within one tsunami wave or to different tsunami waves. However, the time required for mud (silt and clay flocculates) to settle out of suspension is probably on the order of minutes, so the discrete mud laminae implies different tsunami waves.

Comparisons of the 1964 Tsunami Impacts in Seaside with other Pacific Northwest Localities

The observed amplification and attenuation of the 1964 tsunami surges in Seaside are compared to runup evidence from other nearby localities including Warrenton, Gearhart, and Cannon Beach, Oregon and Sea View, Washington (on Long Beach peninsula). Sea View had a maximum wave amplitude of $3.8 \mathrm{~m}(12.5 \mathrm{ft}$.) and no damage occurred (Lander and others, 1993). At Warrenton no runup heights were observed, but some damage occurred along the waterfront. Gearhart, immediately to 
the north of Seaside, encountered some flooding and deposits of sand, but wave heights were not observed wave heights. Cannon Beach (immediately south of Tillamook Head) sustained a considerable amount of damage. The HWY. 101 bridge crossing Elk Creek was washed $0.3 \mathrm{~km}$ upstream and logs, debris, and sand were deposited in the street (Lander and others, 1993). From these comparisons, the Seaside runup and corresponding damage were anomalously large, relative to nearby localities.

The 1964 tsunami runup in Seaside is also compared to two of the other most impacted farfield sites in the Pacific Northwest, including Port Alberni on Vancouver Island, British Columbia and Crescent City, in northern California. Three surges of the 1964 tsunami inundated Port Alberni up to 4-4.9 m (13-16 ft.), leaving a 1-2 cm thick sand deposit $11 \mathrm{~cm}$ below the present marsh surface. There was some amplification due to a pipeline which impeded the wave progress, resulting in a $15 \mathrm{~cm}$ thick sand deposited locally (Clague and others, 1994). In Crescent City, four surges attacked the waterfront, the last being the largest and most destructive (6.3 $\mathrm{m}$ above MLLW). The first surge at Crescent City was $4.3 \mathrm{~m}$ (14 ft.) above MLLW (Lander and others, 1993). The inundation distances in small tidal creeks for both Port Alberni and Crescent City were not as extensive as Seaside. However, both localities showed local amplification due to obstructions and attenuation across overland flats and upstream in narrow tidal creeks. 
Correspondence between 1964 Tsunami Runup and Tsunami Depositional Record

In Seaside, the historic geologic record of 1964 tsunami deposition corresponds very well with reported observations of runup height, multiple surges, and localized amplification or attenuation in the tidal creek wetlands.

Fining upward sequences were apparent in the 1964 sand layers however, no sedimentary structures establishing paleoflow direction were observed. No crossbedding or evidence of flop-overs were observed in recovered cores or trench walls, even where standing waves and buried flop-overs were reported (sites SSW 725, 726, $1 \mathrm{~A}$ and 1B). The lateral changes in sand layer thickness over distance scales of 10's to 100 's of meters clearly corresponds to areas of rapid flow deceleration and catastrophic deposition of suspended sand-sized sediment (Figure 65 and Figure 66).

The preservation potential of historic geologic records is likely to be low in many of the upland sites in Seaside. Rain, wind, vegetation growth, and burrowing organisms are likely to have disturbed the 1964 tsunami deposits beyond recognition in upland soil sites. For example, shallow cores in supratidal dune-ridge deposits of the west Neacoxie Creek valley (1.8 $\mathrm{m}$ in elevation) showed weak or no evidence of distinct tsunami sand layers, where such layers were reported to have been deposited in 1964 (SSW 703,704). In contrast, the 1964 tsunami deposits are very-well preserved in the Necanicum and Neawanna tidal creek wetland soils. The tsunami-deposited sand layers in the wetland soils are intact, show little disturbance by root growth, and preserve both contact relations and alternating sand and mud laminae. 


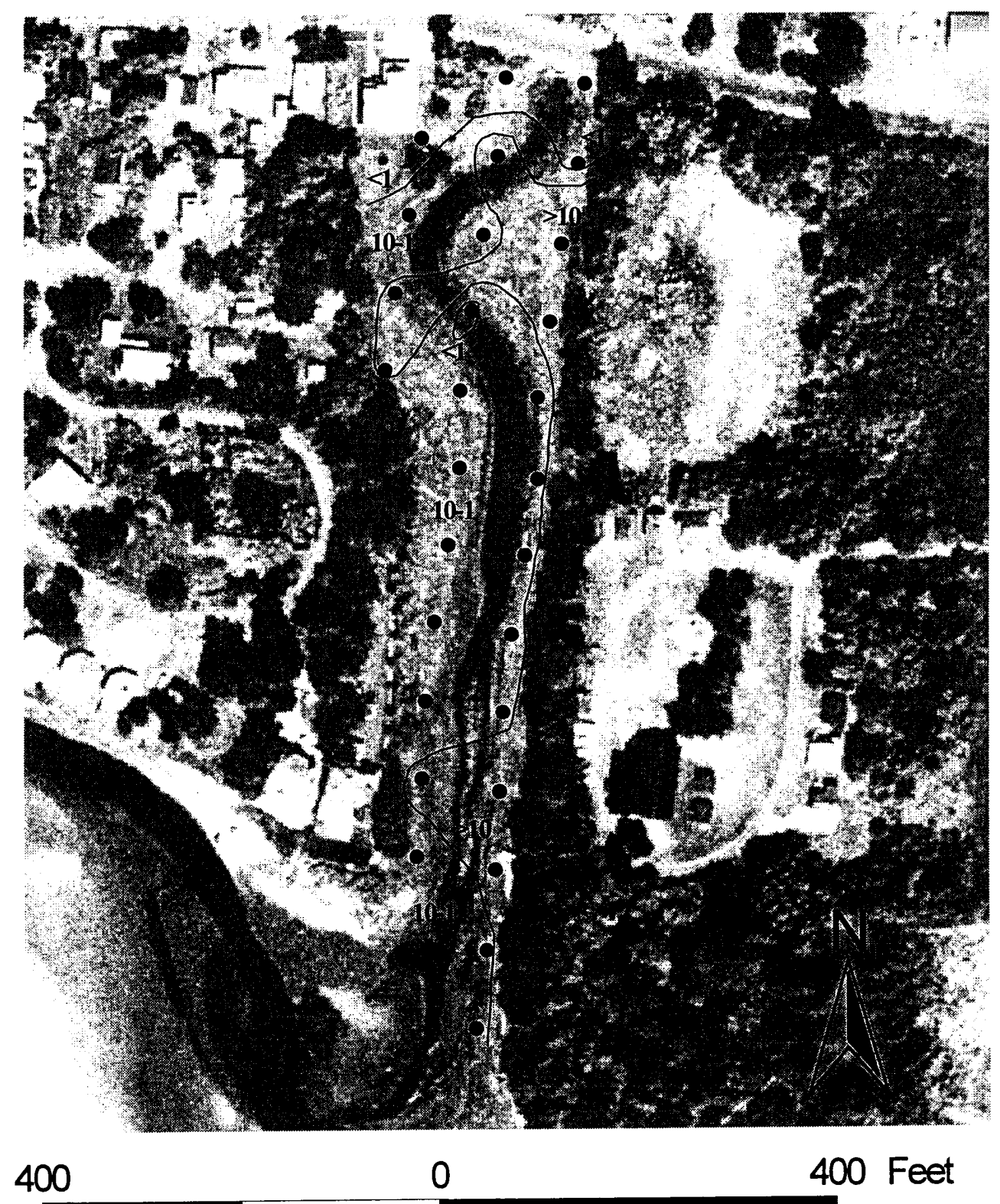

- SSX grid core locations

Figure 65. 1964 SSX grid isopach, determining thickness of the sand sheet in Seaside. 


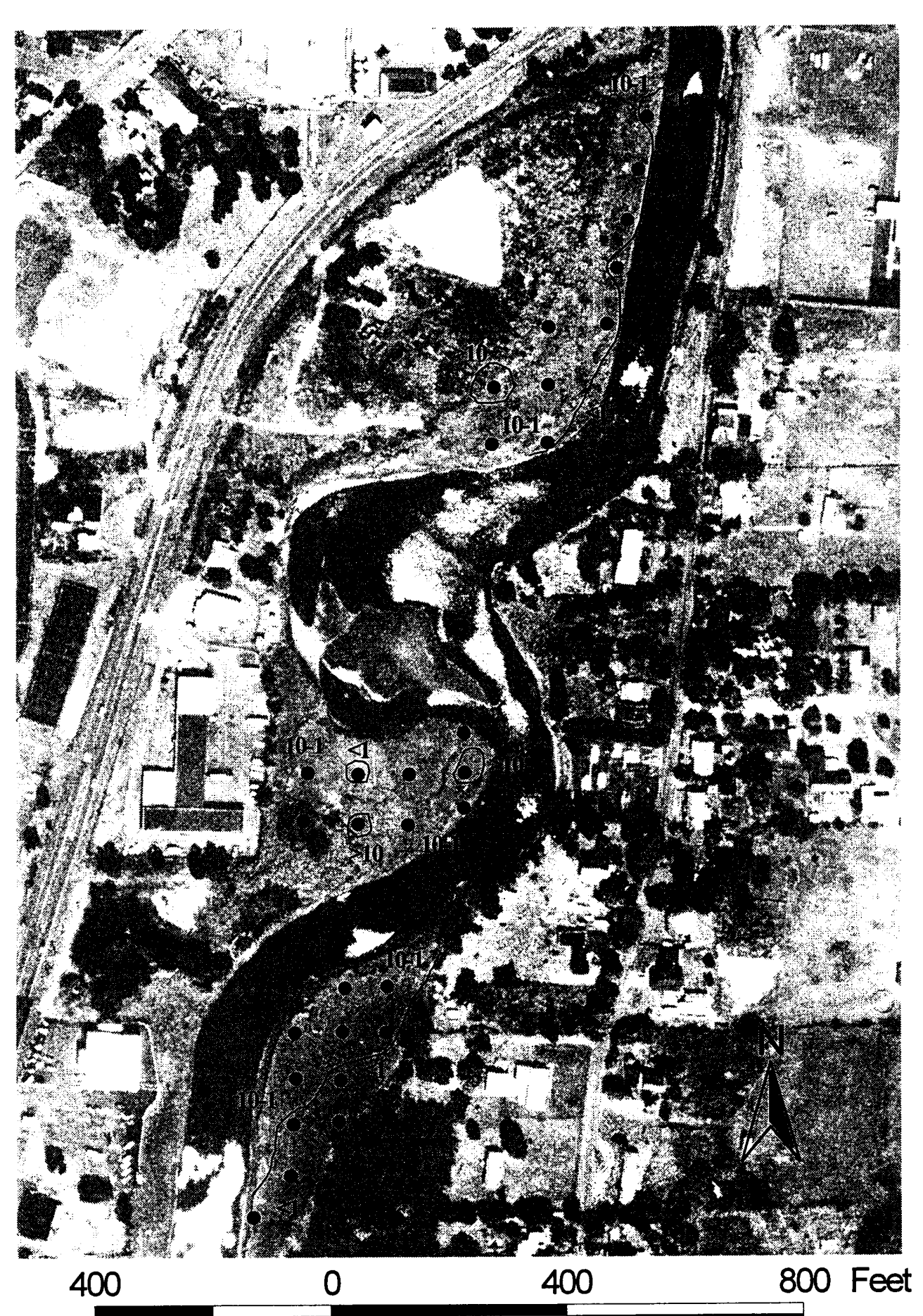

- SSW grid core locations

Figure 66. 1964 SSW grid isopach, determining thickness of the sand sheet in Seaside. 
1964 Runup

Based on the observation sites and core locations for the 1964 event in Seaside, an inundation map of the area has been produced (Figure 67). This map includes Priest's (1995) worse case scenario Cascadia inundation line for the Seaside area, based on three scenarios of computer models, local topography, and historic and prehistoric tsunami inunation evidence. Primary inundation by the 1964 tsunami occurred within the wetlands of the Necanicum River $(4 \mathrm{~km})$, Neacoxie Creek $(0.5 \mathrm{~km})$, and Neawanna Creek $(3.5 \mathrm{~km})$. There was also wave runup along the shoreline of Seaside reaching the promenade (4-4.9 $\mathrm{m}$ in height). The remainder of this discussion section will focus on the prehistoric records of Seaside wetland stratigraphy and Cascadia (nearfield) tsunami inundation.

\section{Paleogeography of the Seaside Wetlands}

Some understanding of the recent paleogeography of the Seaside tidal creeks is necessary for interpretations of paleotsunami inundation of the Seaside wetlands in late prehistoric time. The primary objective in investigating the paleogeography of Seaside is to establish the location of the Necanicum River during the time of the last prehistoric tsunami. The study by Rankin (1983) and the cobble locality mapping for this thesis established that the cobble ridges are extensive throughout the southern portion of Seaside and gradually thin to the north. The ridges of northern Seaside trend N-S, and in the south near the cove, they have a NE-SW trend reflecting shoreline attachment to Tillamook Head to the south. These cobble ridges primarily control the channelways of the Necanicum River and Neawanna Creek. Rankin (1983) 


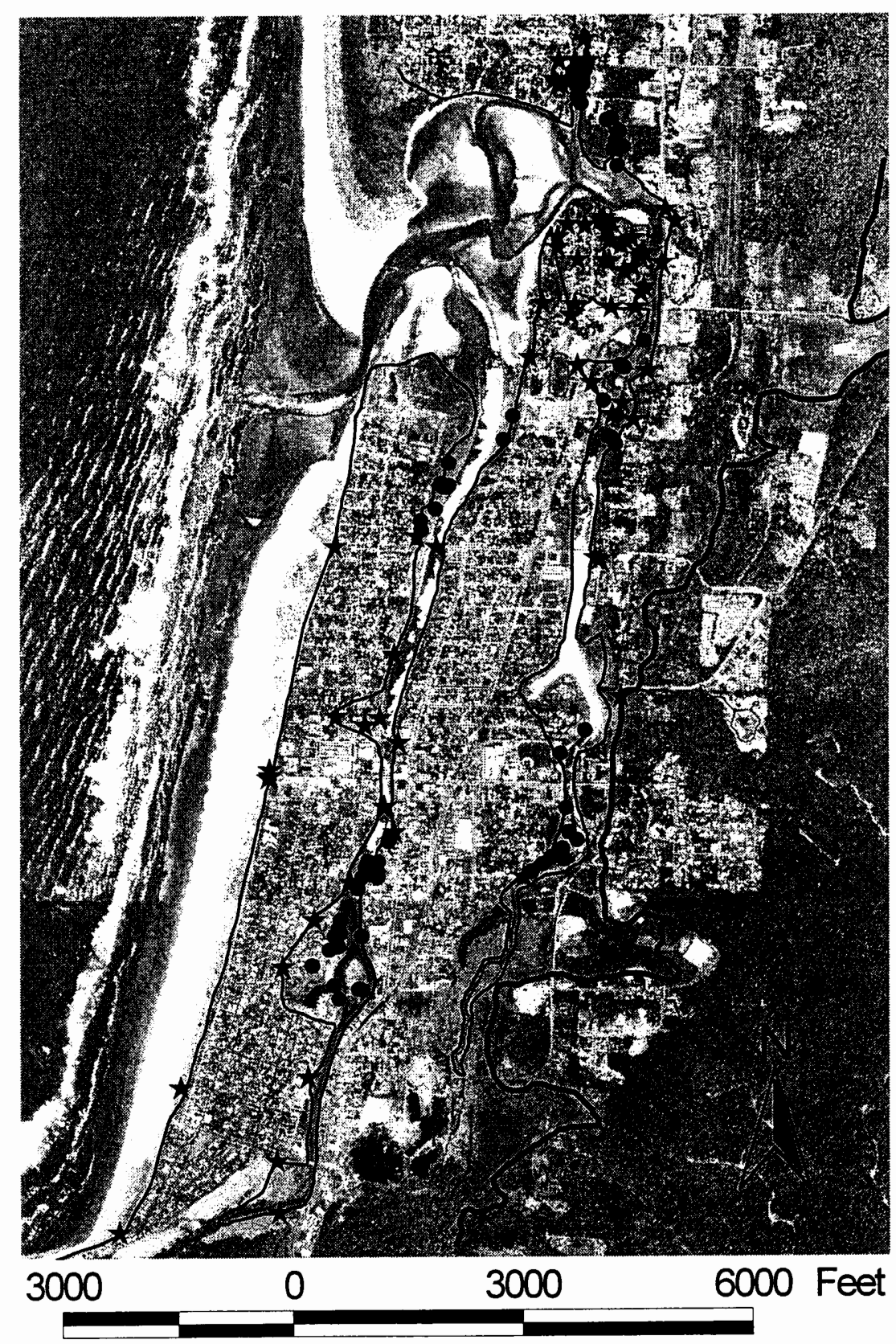

$$
\begin{aligned}
& \star 1964 \text { observation sites } \\
& 1964 \text { core locations } \\
& \text { Approximate } 1964 \text { Runup } \\
& \text { Worse-case Scenario (Priest, 1995) }
\end{aligned}
$$

Figure 67. 1964 observation sites and gouge core deposit locations including 1964 inundation line. Bold line represents Priest's (1995) worse case scenario inundation line. 
believed that the cobble ridges were deposited in pulses separated by periods of erosion and stabilization over the last 3,500 years. Also, he attempted to correlate the age of the northern dunes of the Clatsop Plains to the cobble ridges of Seaside. He determined that the eastern bank of Neawanna Creek would be the 1500 year ridge line, whereas the 400 year ridge line would be just east of the primary dune in Seaside (west of the Necanicum River). Darienzo's work (Connolly, 1992) for the native American midden sites (Figure 5) found that some of the correlations Rankin made do not coincide with the radiocarbon ages for the midden sites (Connolly, 1992). For example, the Palmrose site has an occupation radiocarbon age of approximately 3650 years BP that roughly agrees with the ridge age by Rankin extrapolated to be $3200-$ 3500 years. However, the Avenue Q site lies on a gravel ridge east of the Necanicum River (estimated by Rankin as 800 years) with a radiocarbon occupation date of 3280 years BP. In addition, tidal marsh deposits in the Neawanna Creek extend back to 2,000 RCYBP (Darienzo and others, 1993). Rankin (1993) then noted that the gravel ridges must react independently of the dune ridges to the north.

Phebus and Drucker (1979) produced radiocarbon dates for the abandonment of two midden sites as approximately 1300 and 1600 years BP for the Avenue Q and Palmrose sites, respectively. From the results of this study and from Darienzo (1991), none of the midden site abandonments correlate with the youngest subsidence/tsunami event dated to about $1700 \mathrm{AD}$. Bay clams from these middens suggest that there may have been a nearby bay from which to obtain these clams between 1300 and 3650 years 
PB. An abandonment of the youngest midden after 1300 RCYBP implies a disappearance of the bay clam source after this period. Toward the last years of midden occupation, sand presence increased, indicating that the bay was filling in with sand (Connolly, 1992). This might indicate that there was not a bay influence in the southern portion of Seaside during the most recent Cascadia event.

The Lewis and Clark sketch maps of the Seaside area from their expedition west in 1804-1806 yield more questions than answers in dealing with the late-prehistoric geomorphology of the Seaside area (Figure 4). Only one dominant river channel is indicated on the map, and it is labeled the Clatsop River. The river labeled the Necanicum flows to the north, and its mouth empties into the ocean north of present day Seaside. This sketch map makes it difficult to determine the paleoshoreline due to the lack of consistency with the naming and presence of today's waterbodies. The maps of Lewis and Clark could be correct if the Necanicum River was not in its present position in 1806. However, an outlet to the south of its present position is not shown in their sketch. This would also mean that Neawanna Creek is the Clatsop River in the sketch map.

These discrepancies are difficult to reconcile. Lewis and Clark were competent mappers, but could they have missed the Necanicum River? Or is it the Necanicum River that is mapped (as Clatsop River), and they missed Neawanna Creek? If the Necanicum River was not mapped, it would have had to establish itself within the 
interval between the exploration by Lewis and Clark and the appearance of the first settlers (less than 100 years).

From what is known from the cobble and dune ridge stratigraphies at the Seaside High School, the mouth of the present Necanicum River must have been slightly south of its present location to allow sand transport from the beaches to cover the cobble ridges. This mouth migration to the north could have occurred within the last several hundred years. No definite conclusions about the Seaside paleoshoreline and river mouth locations can be reached from the Lewis and Clark sketch maps.

Finally, prehistoric landslide debris (debris flow deposits reported by Darienzo and others, 1993) was identified in the central Neawanna Creek wetlands. Initially, shaking from a Cascadia earthquake was thought to be the cause of a landslide from the foothills of the Coast Range to the east. If that is correct, then the deposits of the landslide should occur in the stratigraphic position overlying a muddy peat (SSW 790, 793-94, 803, 819-821). However, they are associated within a rooted or peaty mud. At present there is no evidence to indicate correlation between the landslide deposit and a prehistoric Cascadia earthquake, contradicting the hypothesis introduced by Darienzo and others, 1993.

\section{Paleosubsidence Horizons in Seaside}

Regional abrupt coastal subsidence provides timelines for correlation of paleotsunami deposition resulting from nearfield Cascadia interplate earthquakes in the Seaside area. 
In the Necanicum River wetlands, 35 sites out of 37 showed no evidence of buried peaty horizons in the upper $50-100 \mathrm{~cm}$ of the cores. Only two sites (SSN 882, 884) had any evidence of a buried peaty horizon, but SSN 884 at $71-80 \mathrm{~cm}$ yielded an age of $109 \pm 0.9 \%$, possibly too young to be correlated to the $1700 \mathrm{AD}$ event. Weak subsidence from the $1700 \mathrm{AD}$ event was found in 1 out of 10 core sites in the Neacoxie Creek wetlands, 4 out of 10 sites in the drainage to the east of Neacoxie Creek, and 4 out of 18 sites in the Stanley Lake area.

The core sites that do show some evidence of buried wetlands indicate relatively small amounts of abrupt sea-level change. For example, most sections include rooted mud (colonizing marsh) overlying peaty mud or muddy peat (established marsh). Barnett (1997) reports these transitions to represent one meter or less of subsidence in the Seaside tidal-creek wetlands. Although diatom salinity changes across these subtle burial contacts do confirm abrupt paleosubsidence in the Mill Creek site (SSS 879-881) the patchy record of wetland burial along the northern and eastern margins of the Necanicum estuary implies weak tidal influence there. As previously noted, the lack of multiple buried wetlands in these core sites indicates that tidal influence in this area began only shortly before the last paleosubsidence event about 300 years ago.

By comparison, the Neawanna wetlands north of 12th Avenue bridge contain more consistent evidence of paleosubsidence. In this area, 7 out of 12 core sites record evidence of a buried wetland within $50-80 \mathrm{~cm}$ depth. Although possibly contaminated by descending roots, the radiocarbon dates $(101.6 \pm 0.9 \%-360 \pm 70$ RCYBP) from the 
shallowest 1-2 buried wetlands are consistent with the shallow depths of these horizons. The record of paleosubsidence in this core depth interval diminishes with increasing distance south (upstream). For example, 17 out of 71 core sites demonstrate clear evidence of significant subsidence, e.g., rooted mud overlying peaty mud or muddy peat between the 12th Avenue bridge and the S Avenue bridge. Whereas lateral channel migrations have eroded out some buried marsh sections directly adjacent to the Neawanna channel, some core sites located 10's of meters away from the modern channel contain one or more buried wetland horizon above one meter depth.

\section{Subsidence Horizon}

Subsidence horizons of the youngest buried peat (1700 AD) events have been identified in Washington (Atwater, 1987) and Oregon (Darienzo and Peterson, 1990). Yamaguchi and others (1989) produced a more accurate date for the $1700 \mathrm{AD}$ event by dendrochronology. Satake and others (1996) found prehistoric tsunami evidence along with written historic records in Japan which indicate a possible Cascadia earthquake on January $26,1700 \mathrm{AD}$ at 2100 local time. These studies confirm the evidence for a $1700 \mathrm{AD}$ subsidence horizon and an interplate earthquake generating a large tsunami along the Cascadia margin.

Tsunami-deposited sand layers of the prehistoric events are identified in part by their position above an abrupt subsidence contact. However, throughout the Seaside wetlands, the subsidence intervals are weak $(<0.5 \mathrm{~m})$, and many do not contain overlying sand deposits. The wetlands of Seaside lie in a dilute-brackish setting. They 
experience weak tidal influence, and they probably record minor coseismic subsidence $(<1.0 \mathrm{~m})$. In some cases, sand has been injected into overlying muddy peats or muds. The coseismic liquefaction creates a reverse stratigraphy where the intruded clastic sills underlie the abrupt subsidence contact.

From the above information, a horizon for the $1700 \mathrm{AD}$ subsidence event can be determined. The shallowest, i.e., the youngest buried interval, represents the $1700 \mathrm{AD}$ event i.e., last large proximal earthquake to occur in the central Cascadia margin. No overlying buried peats or liquefaction features indicators should exist above this interval. Furthermore, it should have a relatively young prehistoric date $(<500$ RCYBP).

Stanley Lake area contains some possible young subsidence horizons. Only core sites SSS 879-881 exhibit the correct stratigraphy which includes a thin TSL above the buried peat horizon. Diatom samples at SSS 879 indicate an increase of marine diatoms relative to brackish diatoms just above the buried subsidence horizon at $54 \mathrm{~cm}$ depth below the modern marsh surface.

The Neawanna Creek wetlands contain the best evidence of preserved prehistoric subsidence horizons. The youngest buried horizon fits the criteria for the $1700 \mathrm{AD}$ event. This horizon ranges from $45-85 \mathrm{~cm}$ from the present surface. The radiocarbon dates from some sites are younger than would be expected from this horizon, but these deposits are likely contaminated by young carbon from descending roots. The only exception to this is core site SSW 716. This core contains a subtle peaty mud (at 54 
$\mathrm{cm}$ ) above the $1700 \mathrm{AD}$ horizon $($ at $81 \mathrm{~cm})$. The lower radiocarbon date (at $81 \mathrm{~cm}$ ) seems to be correct, having a $1700 \mathrm{AD}$ horizon date of $360 \pm 70 \mathrm{RCYBP}$ for a peaty unit below a TSL, a prime example for the subsidence stratigraphy. Also, Darienzo's radiocarbon date of $480 \pm 60 \mathrm{RCYBP}$ at $50 \mathrm{~cm}$ for his Neawanna 2 core site correlates well with the stratigraphy of core SSW 787, and it verifies the upper Neawanna Creek $1700 \mathrm{AD}$ horizon. The younger radiocarbon dates near the Mill Ponds (SSW 729, 831, and 832 ) were most likely contaminated by the modern roots observed to be extending into the lower peat and mud.

\section{Older Subsidence Horizons}

This study is focused on the historic 1964 and prehistoric $1700 \mathrm{AD}$ events, therefore deep coring was not conducted. Areas northeast of the S Avenue bridge and near the Mill Ponds contained the only evidence for older prehistoric horizons. The next buried horizon under the $1700 \mathrm{AD}$ event north of S Avenue occurs $72-100 \mathrm{~cm}$ from present surface. Darienzo's (1991) Neawanna 2 correlates with core SSW 787 indicating an approximate age for the horizon of $1100 \pm 70$ RCYBP. The second buried horizon near the Mill Ponds ranges $82-100 \mathrm{~cm}$ from present surface, however the radiocarbon samples at SSW 831 and 832 again have younger radiocarbon dates than expected. This is interpreted to be the result of modern root contamination of the samples. Diatom evidence in core SSW 831 at the $81 \mathrm{~cm}$ contact indicates an abrupt change from fresh/brackish to marine/brackish conditions at the buried wetland contact.

The diatom data confirms the evidence for a subsided horizon. Therefore, the second 
buried horizon is correlated to the second horizon (1,100 RCYBP) northeast of S Avenue bridge. A possible third horizon northeast of S Avenue bridge occurs in core sites SSW 788 and 784 at roughly $160 \mathrm{~cm}$, and both buried horizons have a TSL above. This horizon can possibly be correlated to Darienzo's (1991) Neawanna 2 date at the fourth buried interval. The fourth buried horizon was dated at $1370 \pm 70 \mathrm{RCYBP}$ by Darienzo (1991).

In summary, the longest records of episodic burial in the Seaside wetlands, extending back to 2,000 RCYBP, are from the Neawanna wetlands just north of S Avenue bridge (Darienzo, 1991; Darienzo and others, 1993). The south-central portion of the Neawanna Creek valley has been connected to tidal flow during the last 2,000 years.

Upstream of the S Avenue bridge, the record of paleosubsidence is reduced to very subtle changes in peat content, such as sites SSW 828,830 , and 831 .

Confirmation of subsidence is documented by significant changes in diatom salinity tolerance from site SSW 831 southeast of the Mill Ponds. However, an abundance of freshwater species above and below the shallowest burial contact testifies to minimal tidal influence at the southern end of the Neawanna wetlands. A lack of channel sand within the top two meters of peaty mud from the Mill Pond sites (Figure 61) demonstrates that the south end of the Neawanna wetlands have not been in direct contact with the Necanicum channel or a proximal tidal inlet in the last 1,000 years. The cobble ridge that currently separates the southern reaches of the Necanicum and 
Neawanna is presumed to have been in place and unbreached by tidal flow during this time.

Discrimination of Potential Paleotsunami Deposits from Liquefied Intruded Sand Features

Perhaps the most unexpected finding of this study was the abundant and widespread evidence of late-Holocene coseismic liquefaction in the Seaside area. In this section, the evidence of coseismic liquefaction in Seaside is reviewed and compared to other coastal paleoliquefaction sites in the region.

Distinguishing tsunami-deposited sand layers (TSL) from liquefied intruded sands (LIS) relies upon contact relations and associations with the surrounding core site stratigraphy. TSL's are identified by their typical sharp lower contacts with the underlying buried peat, clean sand dominated by quartz, occasional fining upward trends, and overlying rooted mud to mud. Typically, these layers are continuous over some distance, thinning or thickening according to relative location to source of tsunami surge propagation.

LIS layers become difficult to distinguish from TSL's where they occur at or near subsidence contacts. However, many of the LIS layers identified in this study have intruded contacts, where the sand fingers into the host deposit, above or below the intruded clastic sills (SSW 778 and 779). Nearly all the LIS layers underlie buried wetland contacts and are thus easily discriminated from nearfield Cascadia tsunami deposition. Figure 68 shows the distribution of LIS associated with the $1700 \mathrm{AD}$ event 


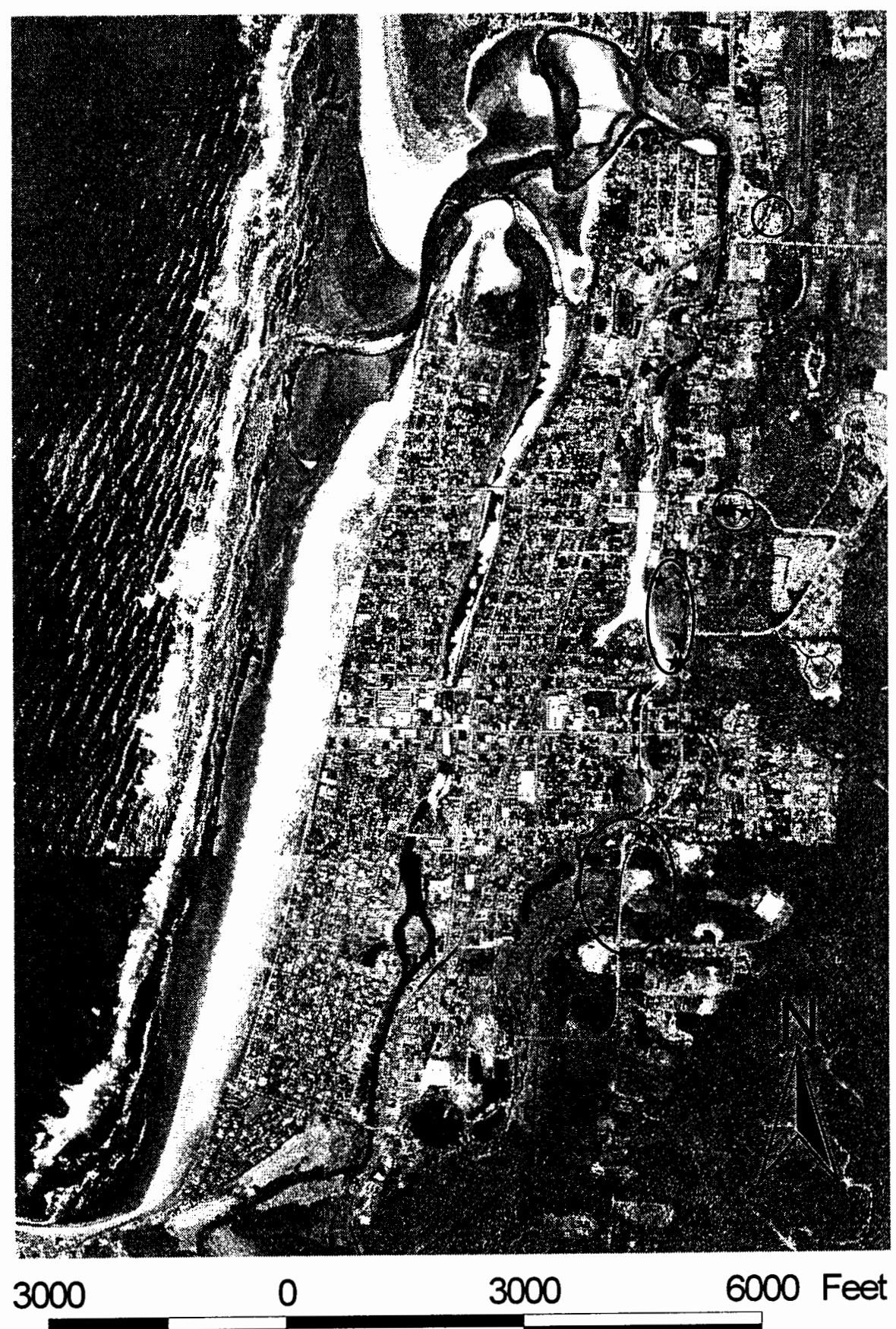

$\star \quad$ LIS (Liquified Intruded Sands)

Liquefaction Zones

Figure 68. Distribution of LIS related to the $1700 \mathrm{AD}$ event liquefaction zones in the Seaside wetlands. 
and liquefaction zones in the Seaside wetlands.

During this reconnaissance study, the primary technique used for observing the subsurface stratigraphy, particularly for the prehistoric deposits, involved a gouge core. With this limited view, some sand layers identified as a TSL could be a LIS. However, when the lateral stratigraphy of target sand layers was inconsistent or discontinuous from core to core in an area, then extensive tightly-spaced coring was performed.

Areas along the Columbia River and central Cascadia margin have been examined for coseismic liquefaction evidence such as dikes and sills (Atwater, 1994; Obermeier, 1995; Peterson and Madin, 1997). The evidence of coseismic liquefaction reported by those authors is very similar to what was found in Seaside. Atwater (1994), Obermeier (1995), and Peterson and Madin (1997) agreed that liquefaction features of the lower Columbia River were produced by at least one subduction zone earthquake (CSZ), the latest features being directly correlated to the most recent Cascadia event of $1700 \mathrm{AD}$. Such indicators of liquefaction include forceful injection of intruded sand from sand source beds at greater depths. Atwater (1994) and Obermeier (1995) indicated that vertical dikes were generally a few centimeters wide. Dikes were found inland at least $90 \mathrm{~km}$ from the coast on islands in the Columbia River. Maximum dike widths and density decrease upstream (Obermeier, 1995; Peterson and Madin, 1997).

In this study, the dominant liquefaction features observed were clastic sills. The sills extended along the bottoms of peaty horizons for 10 's of meters in lateral extent. Small clastic feeder dikes were rarely observed. No large dikes were found in cutbanks 
of the Neawanna Creek. The similarities between these features and those reported for the Copalis River site (event dated at 1,100 \pm 200 RCYBP) by Atwater (1992) implies similar origins for both. That is to say that these similarities between the Copalis and Seaside paleoliquefaction sites indicate the sills in Copalis may represent liquefaction from a subduction earthquake, and not from deep fissures, as initially proposed by Atwater (1992).

\section{AD Paleotsunami Inundation}

The $1700 \mathrm{AD}$ subsidence horizon is fairly continuous throughout the Seaside wetlands of Neawanna Creek. However, evidence for tsunami deposits (TSL or SCL) at this contact is fairly weak and patchy or non-existent (see results). In the following section, the aeral distribution of TSL deposits are compared to evaluate possible inundation mechanisms of the $1700 \mathrm{AD}$ paleotsunami in Seaside.

\section{Test of Barrier Overtopping}

Barrier overtopping occurs when a tsunami surges over the higher elevations of a spit barrier. By comparison, channelized surge occurs when the tsunami remains within the low lying channels of rivers, creeks, and their wetlands. Barriers are now developed for residential, commercial, and recreational use. The potential danger of a tsunami overtopping a barrier, and thereby causing extensive loss of life and damage, depends upon the magnitude and proximity of the generating earthquake. For example, the 1964 farfield tsunami at Seaside inundated the mouth of the Necanicum estuary and 
surged up the major channels. Wave splash or minor flooding occurred along the promenade, but no major barrier overtopping occurred.

By examining the $1700 \mathrm{AD}$ horizon and the spatial distributions of TSL and SCL, hypotheses can be formulated as to how this nearfield tsunami inundated the Seaside area. Generally, the TSL and SCL deposits for the $1700 \mathrm{AD}$ event are thin and patchy in the Neawanna wetlands and have yet to be found anywhere west of the Neawanna wetlands. The majority of the TSL deposits occur in the areas just north of the 12th Avenue bridge (SSW 716) and northeast of the Mill Ponds. Central SCL deposits are very localized and are possibly of LIS origin, and they occur near Broadway Drive bridge crossing Neawanna Creek (SSW 847 and 762). Cores located just north of S Avenue bridge and to the southeast of the Mill Ponds contain the greatest abundance of TSL and SCL deposits. However, the TSL and SCL deposits are consistently very thin $(\leq 2 \mathrm{~cm})$, so source directions are difficult to establish there. The majority of the cores containing the $1700 \mathrm{AD}$ prehistoric subsidence horizon on the western banks of the Neawanna Creek do not contain any TSL or SCL sand deposits. Only cores SSW 716 and 717 (797, 806, and 813 weak) contain TSL on the west bank. Therefore, widespread overtopping of the cobble barrier separating the Necanicum and Neawanna valleys is ruled out. Even a dilute surge (carrying no sand over vegetative surfaces) would have resuspended sediment in the Neawanna channel axis and deposited sand on the eastern marsh banks. There is no evidence for such overtopping tsunami surge deposition throughout the central Neawanna reaches. 
By comparison, channelized surges entering the north or south end of the Neawanna Creek may be more plausible. In the 1964 event, the sand deposits are well preserved along both banks of the rivers and creeks. So, a channelized surge origin along the full length of the Neawanna channel is ruled out for the $1700 \mathrm{AD}$ event.

A mix of localized overtopping and channelization probably occurred at both the northern and southern portions of Seaside (Figure 69). The surge(s) most likely entered the Necanicum mouth area (somewhere to the south of its present location) and surged north and south along the valley, possibly together with some primary barrier ridge overtopping. The combined flow was apparently sufficient to propagate or locally inundate the northern portion of the Neawanna wetlands and Mill Creek sites. However, the thinning of the TSL $(\leq 2 \mathrm{~cm})$ in close proximity to channel banks and exposed channel sand implies very weak transport energies. Far less, for example, than the channelized surges in the Neacoxie, Necanicum, and northern Neawanna channels from the 1964 tsunami event. Where damaging runup occurred from the 1964 tsunami, the TSL deposits average $6 \mathrm{~cm}$ in thickness. Clearly the hydrography of the modern Necanicum/Neawanna confluence must differ greatly from conditions during the large $1700 \mathrm{AD}$ tsunami event.

The southern surge possibly entered the Neawanna Creek wetlands from local overtopping the cobble ridge that separates the Necanicum and Neawanna wetlands. The abrupt subsidence horizons are locally very distinct and the majority of buried horizons do contain TSL/SCL deposits (SSW 789, 787, 818, 735, 730, 830, 832). 


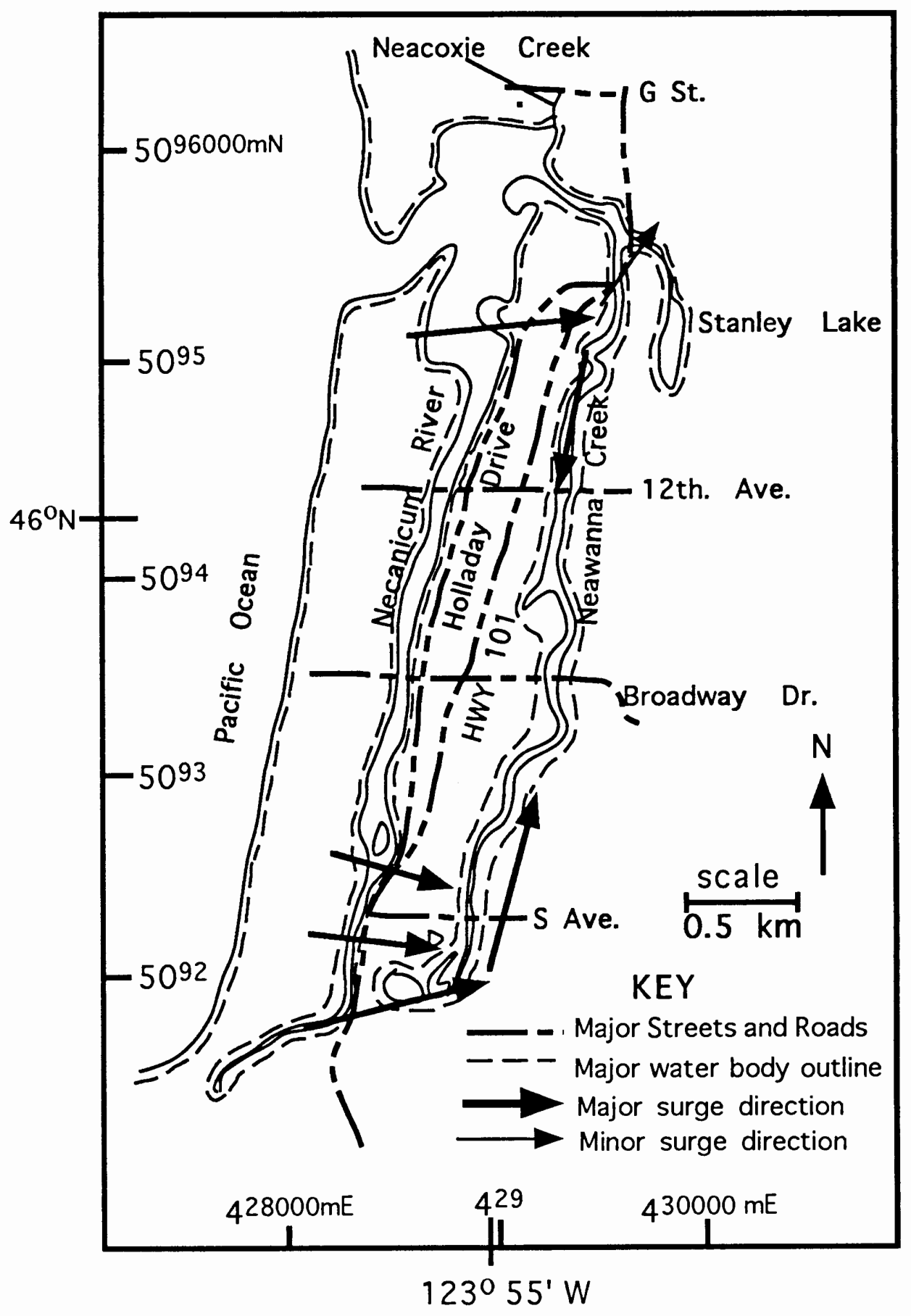

Figure 69. Arrows indicating propagation which possibly occurred during the 1700 $\mathrm{AD}$ event in Seaside. 


\section{Minimum Overland Inundation}

From the above discussion and the distribution of cores containing SCL and TSL deposits, the minimum inundation for the Seaside area can be determined. (Note: both SCL and TSL deposits include a subsidence burial deposit in addition to sand layers) According to Dawson (1994), minimum inundation and runup estimates are represented by the upper limit of the tsunami deposits. Therefore, it can be determined that the minimum inundation from the $1700 \mathrm{AD}$ event is $<1.5$ kilometers from the present day shoreline for the southern to central Seaside wetlands. This information can then be applied to produce a possible inundation map for the $1700 \mathrm{AD}$ event (Figure 70), and practical guidelines for evacuation planning.

\section{Comparisons with other studies}

\section{Historic Events}

The comparison of the findings of this study for the historic 1964 event with Darienzo and others (1993) contain many similarities. Historic sands were identified in the wetlands of the Necanicum River just south of the Avenue G bridge. These sands seem to change in lithology from a beach dominated deposit to the north to river sandrich to the south, and they appear to thin with distance from source, also indicated in this study. Only one core was taken in the Neacoxie Creek (NX 1) wetlands, and it indicates a historic sand layer with a stratigraphy similar to the cores in this study. The cores along the Neawanna Creek obtained historic 1964 deposits just to the north of 12th Avenue bridge. However, cores from this study further to the south show additional evidence of possible 1964 sand layers (SSW 803). Darienzo and 


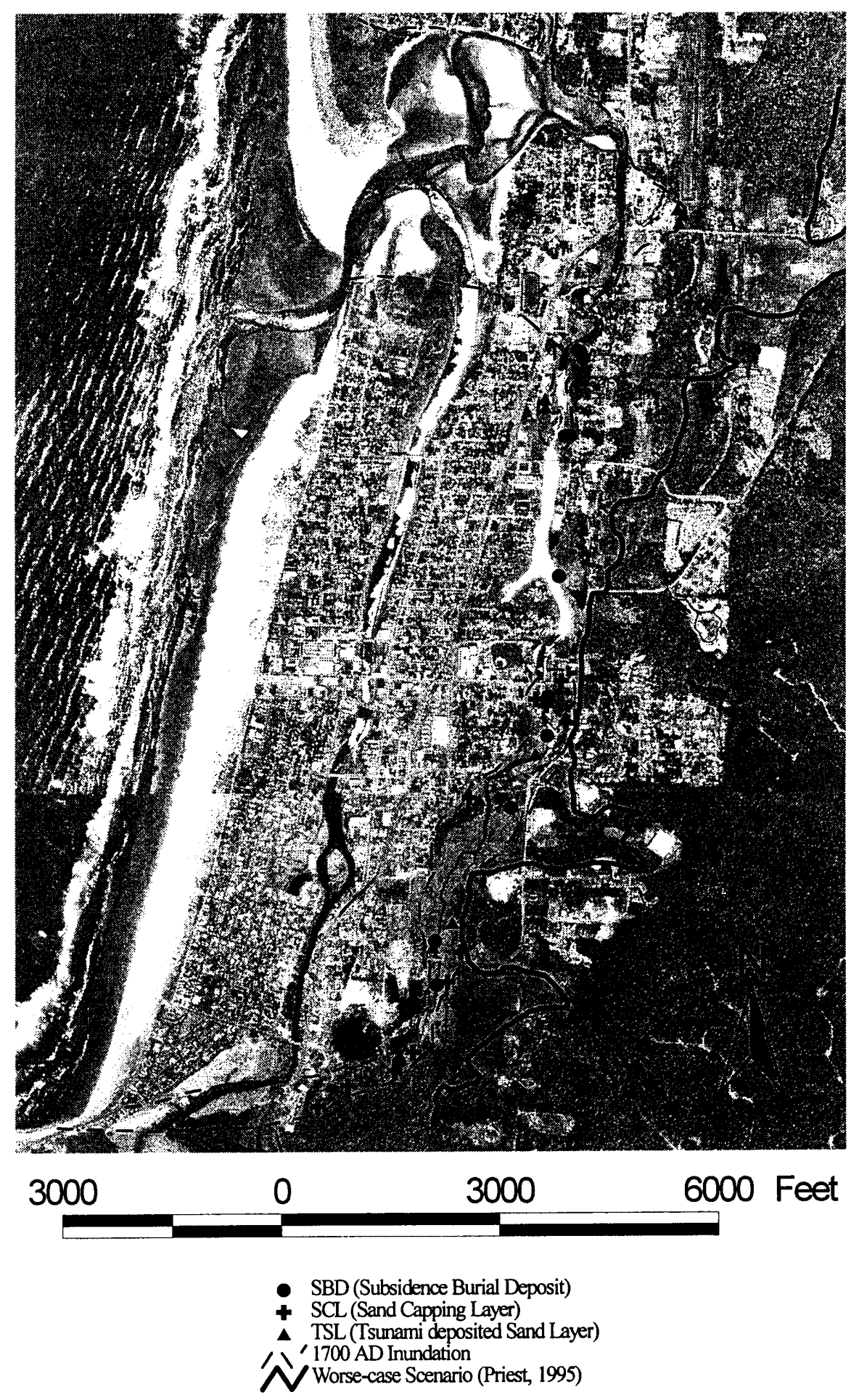


others (1993) also determined that surges affected the Necanicum River and Neawanna and Neacoxie Creeks, although they did not discuss the characteristics of the waves or the deposits.

Numerous historic tsunami have occurred throughout the world. Some historic events have been chosen to compare wave characteristics and runup levels to the 1964 event at Seaside. The Kamchatka area (Kuril-Kamchatka arc and trench of the Pacific $\mathrm{Rim}$ ) is notorious for the occurrence of earthquake tsunami, and in 1923 a M 7.2 earthquake produced a tsunami depositing a thin $(2-3 \mathrm{~cm})$, traceable sand layer up to three kilometers inland (Minoura and others, 1996). At the time of the tsunami event, the land was snow covered, possibly contributing to the extensive inland inundation. Generally, attenuation produces sand deposits which thin landward (Dawson and others, 1988) similar to what was seen along the channelized surges for Seaside. However, in Kamchatka, the deposit is of a fairly uniform thickness introducing an unusual depositional mechanism.

In the last decade, historic tsunami have occurred in Nicaragua (1992), East Java (1994), and Manzanillo, Mexico (1995). The Nicaraguan earthquake (Ms 7.2) produced landward deposits that were correlated to runup heights of 4-6.1 m (13-20 $\mathrm{ft}$. ) along the Nicaraguan coast. The deposits thinned and fined landward eventually becoming undetectable beyond $500 \mathrm{~m}$ inland. Larger clasts were also combined within the deposits, indicating powerful waves that were influenced by local topography and 
sediment supply (Bourgeois and Reinhart, 1993). No large clasts were found within the 1964 deposits in Seaside.

A Ms 7.2 earthquake produced a tsunami in 1994 at the east end of the Java trench. Severe fatalities and damage occurred 250 kilometers from the source. Runup heights for west Bali were 0-4.9 m (0-14 ft.) and .9-13.7 m (3-45 ft.) in southeast Java (Synolakis and others, 1995). Studies also determined that pocket beaches may be more susceptible to tsunami, where deposition does not always occur. Observations of tsunami watermark runup included undercut trees, sand encrusted bark, and sand covered leaves. By comparison, the 1964 event for Seaside did not produce severe damage to vegetation, but did leave abundant evidence of sand deposition, associated with the movement of drift logs, cars, and other debris.

In 1995, an earthquake (Mw 8.0) along the Northern Middle America Subduction Zone produced a tsunami. This tsunami affected $200 \mathrm{~km}$ of coastline and produced .9$4.9 \mathrm{~m}$ of runup (Borerro and others, 1997). At localities with steep onshore topography, damage was minor. Shallow beaches received the most damage. From the north end of Santiago Bay, people on steep cliffs felt the shaking, observed the withdrawal of water from the bay, and then witnessed the wave crashing up the cliff. This area had the highest runup of $11 \mathrm{~m}(36 \mathrm{ft}$.$) . Four to five wave surges were noted,$ the first being the largest. This is similar to the 1964 event in Seaside where observation sites and people verified multiple surges, however, none of the other 
historic studies showed evidence for amplification or surges as recorded in deposits left behind by these historic events.

\section{Prehistoric Events}

There are many similarities between Darienzo and others (1993) and this study. The correspondance for the $1700 \mathrm{AD}$ horizon (Darienzo's 1MT) are consistent for both studies. The $1700 \mathrm{AD}$ subsidence horizon is widespread but laterally discontinuous in the wetlands of Neawanna Creek. The core interpretations in this study for the lower wetlands of Stanley Lake (SSW 872-875) have differing stratigraphies compared to Darienzo and others, 1993 (SL 1 and 3). The radiocarbon dates for SL3 did not support a $1700 \mathrm{AD}$ horizon. The lack of evidence for prehistoric horizons within the Necanicum and Neacoxie wetlands were consistent for both studies. Prehistoric deposits may be underlying the dense basal sand of these areas. Additional reconnaissance investigation into the drainage east of Neacoxie Creek obtained a possible subsidence horizon, but the horizon was inconsistent and lacked some criteria for abruptly buried wetland sequences.

The apparent mechanism of $1700 \mathrm{AD}$ tsunami inundation are also similar for both studies. Although additional cores were taken throughout the wetlands of Seaside, only patchy sand layers are apparent for the $1700 \mathrm{AD}$ event. The location of the buried horizons and TSL are consistent with Darienzo and others (1993). In this study, the propagation of the $1700 \mathrm{AD}$ event along the central reaches of the Neawanna Creek are ruled out. Darienzo and others (1993) indicate a north and south corridor for the 
surge to enter, similar to the interpretation for this study. However, they did not take into account the slightly more southern location for the Necanicum River mouth, allowing for a more southerly entrance for the northern corridor. The southern corridor is very similar to Darienzo and others (1993), although the surge possibly reached farther to the north, due to the increased topography on the east bank of the Neawanna Creek (NE of S Ave. bridge) confining the flow. Implications for Evacuation

Based on the this study, recommendations for evacuation are suggested. Primary evacuation should be to the east of the Necanicum River but not along the Neawanna channel banks. Minimal safety locations are located along higher elevation ridge tops and away from the channel wetlands between the Necanicum and Neawanna channel valleys. Ideal localities (maximum safety) would be the foothills of the Coast Range east of Wahanna Road. Due to the potential for liquefaction of sandy deposits, bridges, buildings, and roadways developed for evacuation should be designed for some loss of foundation support. 


\section{Conclusions}

During the past decade, a considerable amount of research has been conducted into the evidence for prehistoric earthquakes along the Cascadia margin of the United States. Tsunami can be produced by these megathrust earthquakes which enter the low-lying coastal wetlands shortly after the coseismic subsidence occurs, depositing sand and sediment in these areas which slow the wave. Seaside, Oregon, was chosen as a study area due to its low elevation and high population at risk. In addition, it has been affected by a historic tsunami in 1964 which serves as a analog for tsunami surge deposition of sand in wetland settings. The primary objectives of this study were to determine the geologic record of the 1964 tsunami event, and then use this information to evaluate mechanisms of inundation for the youngest prehistoric Cascadia event $(1700 \mathrm{AD})$.

\section{Event}

Geologic evidence of shallow sand deposits from 4-32 cm depth from the present surface corresponds well with the reports of runup, multiple surges, and local amplification or attenuation of the 1964 tsunami surges in Seaside. Amplification of the tsunami wave occurred at the Necanicum River mouth/estuary, producing water heights up to 3.9-4.6 m (13-15 ft.) and depositing 10-31 cm (4-12 in.) of sand along northern Venice Park. Channelized surges traveled up the Necanicum River, Neacoxie Creek, the drainage to the east of Neacoxie Creek, and Neawanna Creek; and these waves attenuated (deposits generally thinning up river). Some areas contain exceptions 
where the deposits thicken due to obstructions, such as the Neacoxie Creek south of G Street. There is weak preserved evidence indicating two possible surges. Intruded contacts, sand boils, dikes or sills suggesting liquefaction were not present or observed for any of the 1964 localities. With this evidence, the inundation zone for the 1964 event in Seaside was determined (Figure 67).

\section{AD Event}

The horizon for the $1700 \mathrm{AD}$ prehistoric tsunami deposits (ranging from 45 to 85 $\mathrm{cm}$ depth) contained weak subsidence sequences with little or no sand deposits at the subsidence contacts. The coastal wetlands of the Neawanna Creek contained the majority of the preserved $1700 \mathrm{AD}$ and other prehistoric subsided horizons. From the characteristics of these deposits, one scenario is preferred in how the wave entered the Seaside wetlands. Specifically, the wave propagated in shore through a northern channelized corridor and southern corridor with localized overtopping of an intact cobble ridge, separating the Neawanna and Necanicum channels. The northern corridor is somewhat south of the present mouth of the Necanicum estuary and the southern corridor is along the low-lying reaches of the Neawanna Creek and the Necanicum River near Avenue U. With this information, an inundation map for the $1700 \mathrm{AD}$ event is produced (Figure 70) that shows localized inundation to 1.5 kilometers from the present coast. 


\section{References}

Atwater, B. F., 1987, Evidence for great Holocene earthquakes along the outer coast of Washington state: Science, v. 236, p 942-944.

Atwater, B. F., 1992, Geologic evidence for earthquakes during the past 2000 years along the Copalis River, southern coastal Washington: Journal of Geophysical Research, v. 97, p. 1901-1919.

Atwater, B. F., 1994, Geology of Holocene liquefaction features along the lower Columbia River at Marsh, Brush, Pine, Hunting, and Wallace Islands, Oregon and Washington: US Geological Survey Open-File Report 94-209, 64p.

Atwater, B. F., Nelson, A. R., Clague, J. J., Carver, G. A., Yamaguchi, D. K., Bobrowsky, P. T., Bourgeois, J., Darienzo, M. E., Grant, W. E., HemphillHaley, E., Kelsey, H. M., Jacoby, G. C., Nishenko, S. P., Palmer, S. P., Peterson, C. D., and Reinhart, M., 1995, Summary of coastal geologic evidence for past great earthquakes at the Cascadia subduction zone: Earthquake Spectra, v. 11, p. 1-18.

Atwater, T., 1970, Implications of plate tectonics for the Cenozoic tectonic evolution of western North America: Geological Society of America Bulletin, v. 81, p. 3513-3536.

Barnett, E. T., 1997, Personal communication regarding diatoms confirming paleosubsidence.

Barnett, E. T., 1997, Potential for coastal flooding due to coseismic subsidence in the central Cascadia margin: unpublished master's thesis, Portland State University, Portland, Oregon, $141 \mathrm{p}$.

Borerro, J., Ortiz, M., Titov, V., and Synolakis, C., 1997, Field survey of Mexican tsunami produces new data, usual photos: EOS, Transactions of the American Geophysical Union, v. 78 , p. 85-88.

Bourgeois, J., and Reinhart, M., 1993, Tsunami deposits from 1992 Nicaragua event: Implications for interpretation of paleotsunami deposits, Cascadia subduction zone: EOS, Transactions of the American Geophysical Union, Fall 1993, v. 74, p. 350 . 
Briggs, G. G., 1994, Coastal crossing of the elastic strain zero-isobase, Cascadia margin, south-central Oregon coast: unpublished master's thesis, Portland State University, Portland, Oregon, 251 p.

Charland, J. W. and Priest, G. R., 1995, Inventory of critical and essential facilities vulnerable to earthquake or tsunami hazards on the Oregon coast: State of Oregon Department of Geology and Mineral Industries, Open File Report O95-02, $52 \mathrm{p}$.

Clague, J. J. and Bobrowsky, P. T., 1994, Tsunami deposits beneath tidal marshes on Vancouver Island, British Columbia: Geological Society of America Bulletin, v. 106, p. $1293-1303$.

Clague, J. J., Bobrowsky, P. T., and Hamilton, T. S., 1994, A sand sheet deposited by the 1964 Alaskan tsunami at Port Alberni, British Columbia: Estuarine, Coastal and Shelf Science, v. 38, p. 413-421.

Connolly, T. J., 1992, Human response to change in coastal geomorphology and fauna on the southern Northwest coast: Archaeological investigations at Seaside: Oregon, University of Oregon Anthropological Papers 45, Eugene, 188 p.

Connolly, T. J. 1995, Archaeological evidence for a former bay at Seaside, Oregon: Quaternary Research, v. 43, p. 362-369.

Darienzo, M. E., 1991, Late Holocene paleoseismicity along the northern Oregon coast: Ph. D. dissertation, Portland State University, Portland, Oregon, p. 167.

Darienzo, M. E., Craig, S., Peterson, C. D., Watkins, A., Wienke, D., Wieting, A., and Doyle, A., 1993, Extent of tsunami sand deposits landward of the Seaside spit, Clatsop County, Oregon: Final report to Clatsop County Sheriff's office, Clatsop County, Oregon, $21 \mathrm{p}$.

Darienzo, M. E. and Peterson, C. D., 1990, Episodic tectonic subsidence of Late Holocene salt marsh sequences in Netarts Bay, Oregon, central Cascadia margin, USA: Tectonics, v. 9, p. 1-22.

Darienzo, M. E. and Peterson, C. D., 1995, Magnitude and frequency of subductionzone earthquakes along the northern Oregon coast in the past 3000 years: Oregon Geology, v. 57, p. 3-12.

Dawson, A. G., Long, D., and Smith, D. E., 1988, The Storegga slides: Evidence from eastern Scotland for a possible tsunami: Marine Geology, v. 82, p. 271-276. 
Dawson, A. G., 1994, Geomorphological effects of tsunami run-up and backwash: Geomorphology, v. 10, p. 83-94.

Griffin, W. H., 1984, Crescent City's dark disaster, tsunami, March 28, 1964, Crescent City, California: Crescent City Publishing Co., Inc., p. 188.

Heaton, T. H. and Kanamori, H., 1984, Seismic potential associated with subduction in the northwestern United States: Bulletin of the Seismological Society of America, v. 74, p. 933-941.

Heaton, T. H. and Hartzell, S. H., 1987, Earthquake hazards on the Cascadia subduction zone: Science, v. 236, p. 162-168.

Horning, T. S., 1996, Personal communication regarding 1964 observations in Seaside, Oregon.

Ingmanson, D. E. and W. J. Wallace, 1995, Oceanography: An introduction: Wadsworth Publishing Company, Belmont, California, 5th ed., 495 p.

Jacoby, G., Carver, G., and Wagner, W., 1995, Tree and herbs killed by an earthquake $\sim 300$ yr ago at Humbolt Bay, California: Geology, v. 23, p. 77-80.

Jol, H. M., Smith, D. G., and Meyers, R. A., 1996, Digital Ground Penetrating Radar (GPR): A new geophysical tool for coastal barrier research examples from the Atlantic, Gulf and Pacific Coasts, USA: Journal of Coastal Research, v. 12, no. 4, p. $960-968$.

Lander, J. F., Lockridge, P. A., and Kozuch, M. J., 1993, Tsunami affecting the west coast of the United States, 1806-1992: US Department of Commerce, National Oceanic and Atmospheric Administration, NGDC Key to Geophysical Records, Documentation No. 29, 242 p.

Minoura, K., Gusiakov, V. G., Kurbatov, A., Takeuti, S., Svendsen, J. I., Bondevik, S., and Oda, T., 1996, Tsunami sedimentation associated with the 1923 Kamchatka earthquake: Sedimentary Geology, v. 106, p. 145-154.

Myers, E., 1994, Numerical modeling of tsunami with applications to the Sea of Japan and Pacific Northwest: Hillsboro, Oregon, Oregon Graduate Institute of Science and Technology master's thesis, $161 \mathrm{p}$. 
Myers, E., 1996, Personal communication regarding tsunami modeling and wave characteristics.

National Academy of Sciences (NAS), 1971, Geology In The Great Alaska Earthquake of 1964: National Academy of Sciences, Washington D. C., 834 p.

National Academy of Sciences (NAS), 1972, Oceanography and Coastal Engineering In The Great Alaska Earthquake of 1964: National Academy of Sciences, Washington D. C., $556 \mathrm{p}$.

Obermeier, S. F., 1995, Preliminary estimates of the strength of prehistoric shaking in the Columbia River valley and the southern half of coastal Washington, with emphasis for a Cascadia subduction zone earthquake about 300 years ago: US Geological Survey Open-File Report 94-589, 46 p.

Peterson, C. D., Barnett, E. T., Briggs, G. G., Carver, G. A., Clague, J. J., and Darienzo, M. E., 1997, Estimates of coastal subsidence from great earthquakes in the Cascadia subduction zone, Vancouver Island, B. C., Washington, Oregon, and northernmost California: State of Oregon Department of Geology and Mineral Industries, Open-File Report O-97-5, $44 \mathrm{p}$.

Peterson, C. D., Darienzo, M. E., Burns, S. F., and Burris, W. K., 1993, Field trip guide to Cascadia paleoseismic evidence along the northern Oregon coast: Evidence of subduction zone seismicity in the central Cascadia margin: Oregon Geology, v. 55, p. 99-114.

Peterson, C. D., Darienzo, M. E., and Clough, C., 1991, Recurrence intervals of coseismic subsidence events in northern Oregon bays of the Cascadia margin: Final Technical Report to the Oregon Department of Geology and Mineral Industries, Open-File Report 0-95-5, 64 p.

Peterson, C. D., Darienzo, M. E., Doyle, D., and Barnett, E., 1996, Evidence for coseismic subsidence and tsunami deposition during the past 3,000 years at Siletz Bay, Oregon: In Priest, G. R., ed. Oregon Department of Geology and Mineral Industries Open-File Report 0-95-5, 25 p.

Peterson, C. D. and Gallaway, P. J., (in progress), Prehistoric nearfield-tsunami inundation of back-barrier wetlands, Cannon Beach, Oregon, USA.

Peterson, C. D., and Madin, I. P., 1997, Coseismic paleoliquefaction evidence in the central Cascadia margin, USA: Oregon Geology, v. 59, p. 51-74. 
Peterson, C. D. and Priest, G. R., 1995, Preliminary reconnaissance survey of Cascadia paleotsunami deposits in Yaquina Bay, Oregon: Oregon Geology, v. 57, p. 3340.

Phebus, G. E., Jr. and Drucker, R. M., 1979, Archeological investigations at Seaside, Oregon: An intermediate report on the excavations of two major archeological sites at Seaside, Oregon, through September, 1977: Seaside Museum and Historical Society, v. 1, p. 43

Plafker, G., 1972, Alaskan earthquake of 1964 and Chilean earthquake of 1960: Implications for arc tectonics: Journal of Geophysical Research, v. 77, p. 901925.

Priest, G. R., 1995, Explanation of mapping methods and use of the tsunami hazard maps of the Oregon coast: State of Oregon Department of Geology and Mineral Industries, Open-File Report O-95-67, 95 p.

Rankin, D. K., 1983, Holocene geologic history of the Clatsop Plains foredune ridge complex: Portland State University unpublished Masters thesis, Portland, Oregon, $189 \mathrm{p}$.

Satake, K., Shimazaki, K., Tsuji, Y., and Ueda, K., 1996, Time and size of a giant earthquake in Cascadia inferred from Japanese tsunami records of January 1700: Nature, v. 379, p. 246-249.

Scatterfield, A., 1964, Tsunami smashes coastal communities: No on hurt when surging tidal wave damages homes, bridges: Seaside Signal, Seaside, Oregon, April 2, 1964.

Spillman, J., 1996, Personal communication regarding the sand deposits overlying grass from the 1964 tsunami on the northern point bar of Neawanna Creek.

Synolakis, C., Imamura, F., Tsuji, Y., Matsutomi, H., Tinti, S., Cook, B., Chandra., Y. P., and Usman, M., 1995, Damage, conditions of east Java tsunami of 1994 analyzed: EOS, Transactions of the American Geophysical Union, v. 76, p. 257-262.

Thwaites, R. G. (ed.), 1905, Original journals of the Lewis and Clark Expedition, 1804-1806, v. 3: Doad and Mead and Co., New York, 460 p. 
Visher, P., 1995, Tsunami disaster planning in Clatsop County, Oregon: University of Washington conference on tsunami deposits: Geologic warnings of future inundation, May 22-23, 1995, $37 \mathrm{p}$.

Wegner, K. R.,1973, Photo-contour maps of Clatsop County, Oregon, North Coast area, T. 6 N., R. 10 W., Contour Interval $=2 \mathrm{ft}$.

Whitmore, P. M., 1993, Expected tsunami amplitudes and currents along North American Coast for Cascadia subduction zone earthquakes: Natural Hazards, v. 8 , p. $59-73$.

Wilson, M., 1989, Igneous Petrogenesis: Unwin Hyman, Inc., London, UK, 466 p.

Yamaguchi, D. K., Woodhouse, C. A., and Reid, M. S., 1989, Tree-ring evidence for synchronous rapid submergence of the southwestern Washington coast about 300 years B P: EOS, v. 70, p. 1468. 
APPENDIX A

1964 OBSERVATIONS 


\begin{tabular}{|c|c|c|c|c|c|c|c|c|c|c|c|}
\hline Site & Date & State & Plane & UTM & UTM & Surf. & Event & Record & Runup & Runup & Veri \\
\hline Number & 1996 & Northing & Easting & Northing & Easting & Elev. & Record & Type & Des. & Elev. & \\
\hline SSB 640 & 10-May & 866710 & 1128684 & 5093494 & 428059 & 16.0 & 1964 & TDL & $\overline{\mathrm{SL}}$ & 17.0 & NP \\
\hline SSB 641 & 10-May & 866724 & 1128700 & 5093498 & 428064 & 23.0 & 1964 & TWM & SPL & & NP,PCx2 \\
\hline SSB 642 & 10-May & 866806 & 1128687 & 5093523 & 428059 & 16.0 & 1964 & & & & \\
\hline SSB 643 & 10-May & 869727 & 1129545 & 5094421 & 428293 & 20.5 & 1964 & TWM & FL & & PC \\
\hline SSB 644 & 10-May & 860789 & 1126742 & 5091672 & 427523 & 16.0 & 1964 & TWM & WL & $16.0 \pm 2.0$ & PC \\
\hline SSB 645 & 10-May & 862657 & 1127521 & 5092249 & 427743 & & 1964 & TDD & & $16.0+2.0$ & $\mathrm{PC}$ \\
\hline SSX 646 & 10-May & 876362 & 1132805 & 5096472 & 429223 & 6.5 & 1964 & TWM & & & $\mathrm{PC}$ \\
\hline SSX 647 & 10-May & 875769 & 1132510 & 5096289 & 429139 & 8.5 & 1964 & TSL & & & $\mathrm{PC}$ \\
\hline SSX 648 & 10-May & 875770 & 1132479 & 5096289 & 429130 & 9.5 & 1964 & TSL $/ \mathrm{TWM}$ & $\overline{\text { WL }}$ & 12.5 & $\mathrm{PC}$ \\
\hline SSX 649 & 10-May & 876092 & 1132463 & 5096387 & 429122 & 13.8 & 1964 & TDD & & 13.5 & $\mathrm{PC}$ \\
\hline SSX 650 & 10-May & 876081 & 1132866 & 5096387 & 429245 & 12.0 & 1964 & TSL/TDL & & 13.2 & PC \\
\hline SSX 651 & 10-May & 876079 & 1132695 & 5096385 & 429193 & 11.0 & 1964 & TDL & & 13.0 & $\mathrm{PC}$ \\
\hline SSX 652 & 10-May & 875823 & 1132421 & 5096304 & 429112 & 9.0 & 1964 & TDD & & 11.0 & $P C$ \\
\hline SSG 653 & 10-May & 861714 & 1128788 & 5091973 & 428137 & 9.5 & 1964 & TDD & & $9.5,7.5$ & PC \\
\hline SSG 654 & 10-May & 861006 & 1128828 & 5091758 & 428156 & 9.0 & 1964 & TDD & & 9.5 & PC \\
\hline SSN 655 & 10-May & 862781 & 1129198 & 5092302 & 428252 & 10.0 & 1964 & & & 10.0 & \\
\hline SSN 656 & 10-May & 864229 & 1128866 & 5092740 & 428138 & 11.0 & 1964 & TWM & WL & 11.8 & $\mathrm{PCx} 2$ \\
\hline SSN 657 & 10-May & 864850 & 1129279 & 5092933 & 428257 & 10.5 & 1964 & TWM & & 11.0 & $\mathrm{PC}$ \\
\hline SSN 658 & 10-May & 865339 & 1129762 & 5093086 & 428400 & & 1964 & & & & $\mathrm{PC}$ \\
\hline SSN 659 & 10-May & 865990 & 1130337 & 5093290 & 428569 & 12.5 & 1964 & TWM & WL & 12.5 & PC \\
\hline SSN 660 & 10-May & 866329 & 1130185 & 5093392 & 428520 & 12.5 & 1964 & TDD & & 12.5 & GP \\
\hline SSN 661 & 10-May & 867194 & 1129815 & 5093652 & 428399 & 12.0 & 1964 & TML & WL,FL & $13.0,14.0$ & \\
\hline SSN 662 & 10-May & 867267 & 1129552 & 5093672 & 428318 & 11.5 & 1964 & TWM & WL & 11.5 & $\mathrm{PC}$ \\
\hline SSN 663 & 10-May & 867503 & 1130111 & 5093749 & 428486 & 12.5 & 1964 & TWM & FL,SL & $14.0,13.5$ & GP \\
\hline SSN 664 & 10-May & 867164 & 1130382 & 5093648 & 428572 & 12.5 & 1964 & $\overline{T W M}$ & WL & 12.5 & $\overline{P C}$ \\
\hline SSN 665 & 10-May & 868305 & 1130312 & 5093995 & 428540 & 12.5 & 1964 & TWM & SL & 12.5 & $\mathrm{PCx} 2$ \\
\hline SSN 666 & 10-May & 869717 & 1130874 & 5094430 & 428698 & 14.5 & 1964 & TWM & SL & 14.5 & PC \\
\hline SSN 667 & 10-May & 869855 & 1130620 & 5094470 & 428619 & 11.5 & 1964 & TDD & & $11.5+$ & $\mathrm{PC}$ \\
\hline SSN 668 & 10-May & 872212 & 1132092 & 5095201 & 429045 & 20.0 & 1964 & TDD & SL & 21.0 & $\mathrm{PC}$ \\
\hline SSN 669 & 10-May & 872812 & 1132253 & 5095386 & 429089 & 19.5 & 1964 & TWM & SL/FL & 20.5 & PC \\
\hline SSN 670 & 10-May & 873794 & 1132450 & 5095687 & 429139 & 11.5 & 1964 & TWM & WL & 13.0 & GP,PC \\
\hline SSN 671 & 10-May & 873653 & 1132456 & 5095644 & 429143 & 13.0 & 1964 & TDD & WL & $13.0+$ & GP \\
\hline SSN 672 & 10-May & 873947 & 1132618 & 5095735 & 429189 & 13.0 & 1964 & TDD & $\mathrm{WL}$ & $13.0+$ & $\mathrm{PC}$ \\
\hline SSN 673 & 10-May & 873944 & 1132824 & 5095736 & 429252 & 11.0 & 1964 & TDD & WL & 11.5 & $\mathrm{PC}$ \\
\hline SSN 674 & 10-May & 874047 & 1133043 & 5095769 & 429318 & 7.5 & 1964 & TWM & WL & 10.5 & $\mathrm{PC}$ \\
\hline SSN 675 & 10-May & 873737 & 1133134 & 5095676 & 429348 & 8.0 & 1964 & TWM & WL & 11.1 & GP \\
\hline SSN 676 & 10-May & 873883 & 1133095 & 5095720 & 429335 & 8.0 & 1964 & TSL/TDL & WL & 11.0 & ST \\
\hline SSN 678 & 10-May & 873999 & 1133131 & 5095755 & 429345 & 7.0 & 1964 & TDL & $\mathrm{WL}$ & 10.5 & \\
\hline SSN 679 & 10-May & 874014 & 1133010 & 5095759 & 429308 & 8.5 & 1964 & TWM & WL & 11.2 & PC \\
\hline SSN 680 & 10-May & 873872 & 1133080 & 5095716 & 429330 & 8.5 & 1964 & TDL & WL & 11.1 & $\mathrm{PC}$ \\
\hline SSN 681 & 10-May & 873471 & 1133125 & 5095595 & 429348 & 8.5 & 1964 & TDL & $\mathrm{WL}$ & 10.7 & GP \\
\hline SSN 682 & 10-May & 873679 & 1133291 & 5095659 & 429397 & 7.0 & 1964 & TDL & WL & 11.5 & $\mathrm{PC}$ \\
\hline SSN 683 & 10-May & 873483 & 1133074 & 5095598 & 429332 & 8.5 & 1964 & TWM & $\mathrm{WL}$ & 10.7 & NP,PC \\
\hline SSN 684 & 10-May & 873759 & 1133399 & 5095685 & 429429 & 7.0 & 1964 & TWM & SL & 13.5 & $\mathrm{PC}$ \\
\hline SSN 685 & 10-May & 873705 & 1133362 & 5095668 & 429418 & 7.0 & 1964 & TDL & WL & 12.5 & $\mathrm{PC}$ \\
\hline \multicolumn{12}{|c|}{ Site Prefix: SSN=Necanicum River, SSW=Neawanna Creek, SSX=Neacoxie Creek, SSXa=Drainage to eart of SSX, and SSS=Staniey } \\
\hline \multicolumn{12}{|c|}{ Lake, SSB = Promenade (Boardwalk), and SSG= Searide golf coune. } \\
\hline \multicolumn{12}{|c|}{ State Plane: North American Datum 1927, northem Oregon, in U.S. zurvey feet. } \\
\hline \multicolumn{12}{|c|}{ UTM: Universal Transverse Mercator coordinates in North American Datum 1927, zone 10, in meters. } \\
\hline \multicolumn{12}{|c|}{ Surface Elevation: CH2MHILL 1973 Datum to the nearest extrapolated one foot $(+1 \mathrm{ft})}$. \\
\hline \multicolumn{12}{|c|}{ Event Record: 1964, 1700 AD, PHU (Prehistoric Unknown) } \\
\hline \multicolumn{12}{|c|}{ Record Type: $T W M=T$ munami high water mark, TDD $=$ Trunami dift debris, $T D L=T$ munami drift loga, $T S L=T$ arget and layer, and } \\
\hline \multicolumn{12}{|c|}{ TML= Trunami mud layer. } \\
\hline \multicolumn{12}{|c|}{ Runup Designators: WL=Water level, $\mathrm{SL}=$ Surge level, $\mathrm{SPL}=$ Splash level, and FL=Foam line. } \\
\hline \multicolumn{12}{|c|}{ Runup Elevation: CH2MHILL 1973 datum (note: Runup nurface-water column height) in feet. } \\
\hline Verification: & NP=Newspa & $\mathrm{er}, \mathrm{PC}=$ Person & commuricatic & $\mathrm{GP}=\mathrm{Ground}$ & otography, an & $\mathbf{S T}=$ Soi & ench & & & & \\
\hline
\end{tabular}




\begin{tabular}{|c|c|c|c|c|c|c|c|c|c|c|c|}
\hline Site & Date & State & Plane & UTM & UTM & Surf. & Event & Record & Runup & Runup & Veri \\
\hline Number & 1996 & Northing & Easting & Northing & Easting & Elev. & Record & Type & Des. & Elev. & \\
\hline SSN 686 & 10-May & 873574 & 1133560 & 5095630 & 429479 & 7.5 & 1964 & TSL/TDL & WL & 11.5 & $\mathrm{PC}$ \\
\hline SSN 687 & 10-May & 873546 & 1133521 & 5095621 & 429468 & 7.5 & 1964 & TSLTWM & WL & 11.5 & GP \\
\hline SSN 688 & 10-May & 873568 & 1133588 & 5095628 & 429488 & 7.5 & 1964 & TSL/TDL & WL & 11.5 & GP \\
\hline SSN 689 & 10-May & 873379 & 1133452 & 5095570 & 429448 & 8.5 & 1964 & TSL/TDL & $\overline{W L}$ & 11.5 & $\mathrm{PC}$ \\
\hline SSN 690 & 10-May & 873344 & 1133312 & 5095558 & 429406 & 8.5 & 1964 & TSL & WL & 11.5 & GP \\
\hline SSN 691 & 10-May & 873139 & 1133571 & 5095498 & 429487 & 8.5 & 1964 & TSL & $\mathrm{WL}$ & 11.0 & $\mathrm{PC}$ \\
\hline SSN 692 & 10-May & 873044 & 1133539 & 5095468 & 429478 & 8.5 & 1964 & TSL/TDL & WL & 11.0 & PC \\
\hline SSN 693 & \begin{tabular}{|l|} 
10-May \\
\end{tabular} & 872845 & 1133471 & 5095407 & 429459 & 10.5 & 1964 & TML & WL & 11.0 & $\mathrm{PC}$ \\
\hline SSN 694 & 10-May & 872873 & 1133170 & 5095413 & 429367 & 8.5 & 1964 & TML & WL & 10.5 & PC \\
\hline SSN 695 & 10-May & 872887 & 1132671 & 5095412 & 429215 & 12.0 & 1964 & TSL/TWM & WL & 12.0 & $\overline{P C}$ \\
\hline SSN 696 & \begin{tabular}{|l|} 
10-May \\
\end{tabular} & 873484 & 1132717 & 5095595 & 429224 & 11.0 & 1964 & TWM & WL & 12.0 & $P C$ \\
\hline SSN 697 & 10-May & 874137 & 1133867 & 5095804 & 429568 & 15.0 & 1964 & TWM & SL & 15.0 & $P C$ \\
\hline SSN 698 & \begin{tabular}{|l|} 
10-May \\
\end{tabular} & 873994 & 1133991 & 5095762 & 429607 & 14.5 & 1964 & TWM & SL & 15.5 & PC \\
\hline SSN 699 & 10-May & 873398 & 1133813 & 5095579 & 429558 & 12.5 & 1964 & TWM & & 13.0 & PC \\
\hline SSW 700 & \begin{tabular}{|l|}
$10-\mathrm{May}$ \\
\end{tabular} & 871994 & 1133593 & 5095149 & 429504 & 10.0 & 1964 & TWM & WL & 10.0 & PC \\
\hline SSW 701 & \begin{tabular}{|l|} 
10-May \\
\end{tabular} & 871387 & 1133449 & 5094963 & 429466 & 10.0 & 1964 & TWM & WL & 10.0 & PC \\
\hline SSW 702 & 10-May & 871862 & 1132904 & 5095102 & 429296 & 10.5 & 1964 & TWM & WL & 10.5 & $\mathrm{PC}$ \\
\hline SSW 703 & 10-May & 871595 & 1133307 & 5095025 & 429421 & 6.5 & 1964 & TSL/TWM & SL & $10.0^{+}$ & $\mathrm{PC}$ \\
\hline SSW 704 & 10-May & 871444 & 1133161 & 5094978 & 429378 & 7.5 & 1964 & TWM & & $10.0+$ & PC \\
\hline SSW 705 & 10-May & 872753 & 1132620 & 5095371 & 429201 & 10.0 & 1964 & TWM & & $11.0+$ & $\mathrm{PC}$ \\
\hline SSW 706 & 10-May & 872096 & 1132715 & 5095172 & 429236 & 9.0 & 1964 & no flooding & & & PC \\
\hline SSW 707 & 10-May & 869577 & 1132952 & 5094407 & 429332 & 6.5 & 1964 & TWM & & 6.5 & $P C$ \\
\hline SSW 708 & 10-May & 869566 & 1133010 & 5094404 & 429350 & 7.0 & 1964 & no flooding & & & $\mathrm{PC}$ \\
\hline SSW 709 & \begin{tabular}{|l|} 
10-May \\
\end{tabular} & 867775 & 1133244 & 5093861 & 429438 & 9.0 & 1964 & no flooding & & & $P C$ \\
\hline SSW 710 & \begin{tabular}{|l|}
$10-\mathrm{May}$ \\
\end{tabular} & 866591 & 1132817 & 5093496 & 429319 & 9.5 & 1964 & no flooding & & & PC \\
\hline SSW 711 & 10-May & 865419 & 1132020 & 5093132 & 429087 & 7.0 & 1964 & no flooding & & & $\mathrm{PC}$ \\
\hline \multicolumn{12}{|c|}{ Site Prefix: SSN=Necaricum River, SSW=Neawanna Creed, SSX=Neacoxie Creek, SSXa=Drainage to eart of SSX, and SSS=Stanley } \\
\hline \multicolumn{12}{|c|}{ Lake, SSB= Promenade (Boardwalk), and SSG= Searide golf courne. } \\
\hline \multicolumn{12}{|c|}{ State Plane: North American Datum 1927, northem Oregon, in U.S. survey feet. } \\
\hline \multicolumn{12}{|c|}{ UTM: Univerral Transverse Mercator coordinates in North American Datum 1927, zone 10, in meters. } \\
\hline \multicolumn{12}{|c|}{ Surface Elevation: CH2MHILL 1973 Datum to the neared extrapolated one foot $(+1 \mathrm{ft})$. } \\
\hline \multicolumn{12}{|c|}{ Event Record: 1964, 1700 AD, PHU (Prehirtoric Unknown) } \\
\hline \multicolumn{12}{|c|}{ Record Type: TWM=Tsunami high water mark, TDD=Tnunami drift debris, TDL=Trunami drift loge, TSL=Target sand layer, and } \\
\hline \multicolumn{12}{|c|}{$\mathrm{TML}=$ Trunami mud layer. } \\
\hline \multicolumn{12}{|c|}{ Runup Designators: WL=Water level, SL=Surge level, $\mathbf{S P L}=$ Splash level, and FL=Foam line. } \\
\hline \multirow{2}{*}{\multicolumn{12}{|c|}{ Runup Elevation: CH2MHILL 1973 datum (note: Runup wrface-water column height) in feet. }} \\
\hline Verification: & $\mathrm{NP}=$ Newspap & $x, \mathrm{PC}=$ Person & minumec & & & & & & & & \\
\hline
\end{tabular}




\section{APPENDIX B}

GOUGE CORE LOG LOCATIONS AND DESCRIPTIONS 


\begin{tabular}{|c|c|c|c|c|c|c|c|c|c|c|}
\hline Site & Date & State & Plane & UTM & UTM & Surf. & Event & Record & Veri & Core \\
\hline Number & 1996 & Northing & Easting & Northing & Easting & Elev. & Record & Type & & Depth \\
\hline SSW 712 & 19-Jun & 868068 & 1132863 & 5093947 & 429319 & 5.0 & $1700 \mathrm{AD}$ & SBD & SC & 82 \\
\hline SSW 713 & 19-Jun & 868064 & 1132926 & 5093946 & 429338 & 5.0 & $1700 \mathrm{AD}$ & SL & SC & 56 \\
\hline SSW 714 & 20-Jun & 869981 & 1132940 & 5094530 & 429324 & 5.0 & $1700 \mathrm{AD}$ & SBD & SC & 88 \\
\hline SSW 715 & 20-Jun & 869974 & 1133037 & 5094529 & 429354 & 5.0 & $1700 \mathrm{AD}$ & SBD & SC & 51 \\
\hline SSW 716 & 20-Jun & 870483 & 1132679 & 5094680 & 429240 & 7.0 & $1700 \mathrm{AD}$ & TSL & SC & 78 \\
\hline SSW 717 & 20-Jun & 870341 & 1132684 & 5094637 & 429243 & 5.0 & $1700 \mathrm{AD}$ & TSL & $\mathrm{SC}$ & 72 \\
\hline SSW 718 & 20-Jun & 871047 & 1133205 & 5094857 & 429395 & 7.0 & $1964 / 1700 \mathrm{AD}$ & TSL/SBD & $\mathrm{SC}$ & $27 / 59$ \\
\hline SSW 719 & 20-Jun & 871126 & 1133164 & 5094881 & 429382 & 7.0 & $1964 / 1700 \mathrm{AD}$ & TSL/SBD? & $\mathrm{SC}$ & $16 / 72$ \\
\hline SSW 720 & 20-Jun & 871151 & 1133117 & 5094888 & 429367 & 7.0 & $1964 / 1700 \mathrm{AD}$ & TSI/SBD & SC & $11 / 79$ \\
\hline SSW 721 & 20-Jun & 866135 & 1132971 & 5093359 & 429370 & 5.0 & $1700 \mathrm{AD} / \mathrm{PHU}$ & TS/SBD & SC & $44 / 94$ \\
\hline SSW 722 & 21-Jun & 872362 & 1133576 & 5095261 & 429496 & 5.0 & 1964 & TSL & SC & 24 \\
\hline SSW 723 & 21-Jun & 872044 & 1133294 & 5095162 & 429413 & 7.0 & 1964 & MSL & $\mathrm{SC}$ & 23 \\
\hline SSW 724 & 21-Jun & 872080 & 1133256 & 5095172 & 429401 & 8.0 & 1964 & TSL & $\mathrm{SC}$ & \\
\hline SSW 725 & 21-Jun & 871400 & 1133210 & 5094965 & 429393 & 7.0 & 1964 & TSL & $\mathrm{SC}$ & 9 \\
\hline SSW 726 & 21-Jun & 871602 & 1133050 & 5095025 & 429343 & 8.0 & 1964 & MSL & SC & 15 \\
\hline SSW 727 & 21-Jun & 867603 & 1132396 & 5093801 & 429181 & 5.0 & $1700 \mathrm{AD} ?$ & SBD? & SC & $72 ?$ \\
\hline SSW 728 & 21-Jun & 864162 & 1131305 & 5092742 & 428881 & 7.0 & $1700 \mathrm{AD} ?$ & SBD? & SC & 74 \\
\hline SSW 729 & 24-Jun & 861404 & 1130667 & 5091896 & 428713 & 7.0 & $1700 \mathrm{AD}$ & SBD & $\mathrm{SC}$ & 75 \\
\hline SSW 730 & 24-Jun & 861265 & 1130506 & 5091853 & 428665 & 7.0 & $1700 \mathrm{AD} / \mathrm{PHU}$ & SCL/SBD & SC & $75 / 103$ \\
\hline SSN 731 & 24-Jun & 863991 & 1129521 & 5092674 & 428339 & 8.0 & $1964 ?$ & MSL & SC & $26-48$ \\
\hline SSN 732 & 24-Jun & 863795 & 1129597 & 5092615 & 428364 & 5.0 & $1964 ?$ & MSL & SC,ST & $37-50$ \\
\hline SSS 733 & 25-Jun & 872572 & 1134787 & 5095336 & 429863 & 3.0 & $?$ & & $\mathrm{SC}$ & \\
\hline SSS 734 & 25-Jun & 872183 & 1134744 & 5095217 & 429853 & 3.0 & $1700 \mathrm{AD}$ ? & $\mathrm{SCL}$ & $\mathrm{SC}$ & 88 \\
\hline SSW 735 & 25-Jun & 862485 & 1131331 & 5092232 & 428905 & 5.0 & $1700 \mathrm{AD}$ & SL & SC & 66 \\
\hline SSW 736 & 25-Jun & 863032 & 1131458 & 5092400 & 428938 & 7.0 & ?/PHU & LSD/SBD & SC & $31 / 93$ \\
\hline SSN 737 & 26-Jun & 864475 & 1129590 & 5092822 & 428356 & 5.0 & 1964 & TSL & SC & 15 \\
\hline SSN 738 & 26-Jun & 864676 & 1129602 & 5092883 & 428357 & 5.0 & 1964 & TSI, & SC & 21 \\
\hline SSN 739 & 26-Jun & 864736 & 1129582 & 5092901 & 428351 & 5.0 & 1964 & TSL & SC & 19 \\
\hline SSN 740 & 27-Jun & 864610 & 1129520 & 5092862 & 428333 & 5.0 & 1964 & MSL & $\mathrm{SC}$ & $11-19$ \\
\hline SSN 741 & 27-Jun & 864441 & 1129459 & 5092810 & 428316 & 5.0 & 1964 & MSL & $\mathrm{SC}$ & $8-18$ \\
\hline SSN 742 & 27-Jun & 864284 & 1129290 & 5092761 & 428266 & 5.0 & 1964 & TSL & $\mathrm{SC}$ & 30 \\
\hline SSN 743 & \begin{tabular}{|l|}
$27-J u n$ \\
\end{tabular} & 864834 & 1129603 & 5092931 & 428356 & 6.0 & 1964 & TSL & SC & 27 \\
\hline SSN 744 & \begin{tabular}{|l|} 
27-Jun \\
\end{tabular} & 865509 & 1129943 & 5093140 & 428454 & 6.5 & 1964 & TSL & $\mathrm{SC}$ & 33 \\
\hline SSN 745 & \begin{tabular}{|l|} 
27-Jun \\
\end{tabular} & 865599 & 1129981 & 5093168 & 428464 & 6.0 & 1964 & MSL & $\mathrm{SC}$ & $31-34$ \\
\hline SSN 746 & \begin{tabular}{|l|} 
27-Jun \\
\end{tabular} & 865390 & 1129895 & 5093103 & 428440 & 7.0 & 1964 & MSL & $\mathrm{SC}$ & $23-29$ \\
\hline SSN 747 & 27-Jun & 865409 & 1130005 & 5093110 & 428473 & 5.0 & 1964 & MSL & $\mathrm{SC}$ & $14-20$ \\
\hline SSN 748 & 27-Jun & 865438 & 1130055 & 5093119 & 428488 & 5.0 & 1964 & MSL & SC,ST & $11-19$ \\
\hline SSN 749 & \begin{tabular}{|l|} 
28-Jun \\
\end{tabular} & 865387 & 1130091 & 5093104 & 428500 & 5.0 & 1964 & TSL & $\mathrm{SC}$ & 28 \\
\hline SSN 750 & 28-Jun & 865583 & 1130100 & 5093164 & 428501 & 5.0 & 1964 & TSL & SC & 17 \\
\hline SSX 751 & 28-Jun & 875749 & 1132782 & 5096285 & 429222 & 5.0 & 1964 & TSI & SC & 15 \\
\hline SSX 752 & 28-Jun & 875803 & 1132792 & 5096302 & 429225 & 5.0 & 1964 & TSL & SC & 14 \\
\hline SSX 753 & 28-Jun & 875878 & 1132806 & 5096325 & 429228 & 5.0 & 1964 & MSL & $\mathrm{SC}$ & $8-22$ \\
\hline SSX 754 & 28-Jun & 875923 & 1132822 & 5096338 & 429233 & 5.0 & 1964 & MSL & SC,ST & $7-39$ \\
\hline SSW 755 & 1-Jul & 867010 & 1132493 & 5093621 & 429216 & 5.0 & $1964 ? / 1700 \mathrm{AD} ?$ & TSL & $\mathrm{SC}$ & $10-14$ \\
\hline SSW 756 & 1-Jul & 867082 & 1132511 & 5093643 & 429221 & 5.0 & $1700 \mathrm{AD} ?$ & $\mathrm{SL}$ & $\mathrm{SC}$ & 53 \\
\hline SSW 757 & 1-Jul & 867328 & 1132822 & 5093721 & 429313 & 7.0 & 1964 & TSL & $\mathrm{SC}$ & 13 \\
\hline SSN 758 & 2-Jul & 865860 & 1130244 & 5093250 & 428542 & 5.0 & 1964 & MSL & SC & $13-22$ \\
\hline SSN 759 & 2-Jul & 865918 & 1130261 & 5093267 & 428547 & 5.0 & 1964 & TSL & SC & 17 \\
\hline SSN 760 & 2-Jul & 865225 & 1129829 & 5093052 & 428421 & 5.0 & 1964 & MSL & SC & $13-32$ \\
\hline SSN 761 & 2-Jul & 864594 & 1129907 & 5092861 & 428451 & 5.0 & 1964 & CSL? & SC & 25 \\
\hline SSW 762 & 2-Jul & 866368 & 1132553 & 5093426 & 429240 & 5.0 & $1964 ? / 1700 \mathrm{AD}$ & $\mathrm{MSL} / \mathrm{SCL}$ & SC & $20-30 / 63$ \\
\hline SSW 763 & 2-Jul & 866296 & 1132567 & 5093404 & 429245 & 5.0 & 1964 & MSL & $\mathrm{SC}$ & $4.5-31$ \\
\hline SSW 764 & 2-Jul & 866427 & 1132728 & 5093446 & 429293 & 5.5 & $1700 \mathrm{AD}$ & SBD & $\mathrm{SC}$ & 65 \\
\hline SSW 765 & 2-Jul & 866356 & 1132722 & 5093424 & 429292 & 5.0 & $1700 \mathrm{AD}$ & $\mathrm{SCL}$ & $\mathrm{SC}$ & 72 \\
\hline SSW 766 & 9-Jul & 866301 & 1132702 & 5093407 & 429286 & 5.0 & $1700 \mathrm{AD}$ & $\overline{S C L}$ & $\mathrm{SC}$ & 53 \\
\hline SSW 767 & 10-Jul & 866207 & 1132749 & 5093379 & 429302 & 5.0 & $?$ & & $\mathrm{SC}$ & \\
\hline SSW 768 & 10-Jul & 866078 & 1132967 & 5093341 & 429369 & 5.0 & $1700 \mathrm{AD}$ & $\mathrm{SCL}$ & $\mathrm{SC}$ & 73 \\
\hline SSX 769 & 10-Jul & 875831 & 1132740 & 5096310 & 429209 & 5.0 & $1964 / 1700 \mathrm{AD} ?$ & TSL/TSL & $\mathrm{SC}$ & $26 / 73$ \\
\hline $\operatorname{SS} \times 770$ & 10-Jul & 875499 & 1132767 & 5096209 & 429220 & 5.0 & 1964 & TSL & $\mathrm{SC}$ & 19 \\
\hline SSX 771 & 10-Jul & 875600 & 1132705 & 5096239 & 429200 & 5.0 & 1964 & TSL & $\mathrm{SC}$ & 18 \\
\hline \multicolumn{11}{|c|}{ 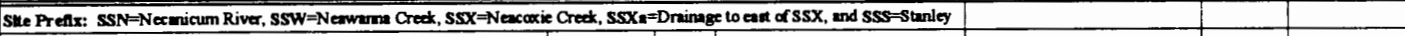 } \\
\hline \multicolumn{11}{|c|}{\begin{tabular}{|l|l|l|l|} 
Lake, SSB=-Promenade (Bourdwalk), SSG-Senside golf courne & & & \\
\end{tabular}} \\
\hline \multicolumn{11}{|c|}{ State Plime: North American Ditum 1927, northem Oregon, in U.S. murvey fect } \\
\hline \multicolumn{11}{|c|}{ UTM: Universal Trensverxe Mereator coord instes in North American D tum 1927, zone 10, in meter. } \\
\hline \multicolumn{11}{|c|}{ 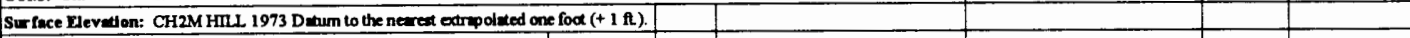 } \\
\hline \multicolumn{11}{|c|}{ Event Record: 1964, 1700 AD, PHU (Prechistaric Unknown) } \\
\hline \multicolumn{11}{|c|}{ Record Type: TSL-T unami-deposited and leyer, MSL=Mud and sand leyor, SL= Send layer, } \\
\hline \multicolumn{11}{|c|}{ SBD= Subsidence burial deposit, LSD=Landslide deposit, LIS=L,iquified intruded and, and SCL=S mand capping bya, } \\
\hline Verification: & SC=Subsurf & Core, $\mathbf{S T}=\mathrm{So}$ & Trench, and $\mathrm{C}$ & $=$ Cutbark. & & & & & & \\
\hline Core Depth: & Subwrface d & th to TSL/CSI & SL lower conte & buried pee & Indi & gial uppe & cartin & & & \\
\hline
\end{tabular}




\begin{tabular}{|c|c|c|c|c|c|c|c|c|c|c|}
\hline Site & Date & State & Plane & UTM & UTM & \begin{tabular}{|l|} 
Surf. \\
\end{tabular} & Event & Record & Veri & Core \\
\hline Number & 1996 & Northing & Easting & Northing & Easting & Elev. & Record & Type & & Depth \\
\hline SSX 772 & 10-Jul & 875727 & 1132682 & 5096277 & 429192 & 5.0 & 1964 & MSL & SC & $12-15$ \\
\hline SSX 773 & 10-Jul & 875814 & 1132631 & 5096303 & 429176 & 6.0 & 1964 & MSL & $\mathrm{SC}$ & $13-24$ \\
\hline SSX 774 & 10-Jul & 875902 & 1132650 & 5096330 & 429181 & 6.0 & 1964 & MSL & $\mathrm{SC}$ & $11-18$ \\
\hline SSW 775 & 11-Jul & 867228 & 1133107 & 5093693 & $42940 \mathrm{I}$ & 5.0 & $1700 \mathrm{AD} ?$ & SL & SC & 47 \\
\hline SSW 776 & 11-Jul & 867246 & 1133006 & 5093698 & 429370 & 5.0 & $?$ & & SC & \\
\hline SSW 777 & 11-Jul & 867243 & 1133063 & 5093697 & 429387 & 5.0 & $1700 \mathrm{AD} ?$ & SCL? & $\mathrm{SC}$ & 85 \\
\hline SSW 778 & 11-Jul & 867489 & 1133116 & 5093773 & 429401 & 5.0 & $1700 \mathrm{AD} ?$ & LIS, SBD & $\mathrm{SC}$ & 60,70 \\
\hline SSW 779 & 11-Jul & 867477 & 1133181 & 5093770 & 429421 & 7.0 & $1700 \mathrm{AD} ?$ & LIS,SBD & $\mathrm{SC}$ & 50,58 \\
\hline SSW 780 & 11-Jul & 868557 & 1132929 & 5094096 & 429334 & 5.0 & $1700 \mathrm{AD}$ ? & LIS, SBD & $\mathrm{SC}$ & 48,55 \\
\hline SSW 781 & 11-Jul & 869210 & 1132631 & 5094292 & 429237 & 5.0 & $1700 \mathrm{AD}$ & TSL? & SC & 54 \\
\hline SSW 782 & 11-Jul & 865341 & 1132636 & 5093114 & 429275 & 7.0 & $1700 \mathrm{AD} ? / \mathrm{PHU}$ & SBD,LIS & $\mathrm{SC}$ & 80,100 \\
\hline SSW 783 & 11-Jul & 865286 & 1132822 & 5093099 & 429332 & 7.0 & $1700 \mathrm{AD}$ ?/PHU & SBD/LIS,SBD? & SC & $43 / 50,118$ \\
\hline SSW 784 & 12-Jul & 863050 & 1131154 & 5092402 & 428845 & 7.0 & $1700 \mathrm{AD} / \mathrm{PHU}$ & SBD/LIS/SBD & $\mathrm{SC}$ & $73 / 153$ \\
\hline SSW 785 & 12-Jul & 863046 & 1131236 & 5092402 & 428870 & 7.0 & $1700 \mathrm{AD}$ ?/PHU? & SBD? & $\mathrm{SC}$ & $56 / 73,143$ \\
\hline SSW 786 & 12-Jul & 863033 & 1131406 & 5092399 & 428922 & 7.0 & $1700 \mathrm{AD}$ & SBD? & $\mathrm{SC}$ & 65 \\
\hline SSW 787 & 12-Jul & 863293 & 1131407 & 5092479 & 428920 & 7.0 & $1700 \mathrm{AD} / \mathrm{PHU}$ & TSL & SC & $42 / 78$ \\
\hline SSW 788 & 12-Jul & 863316 & 1131493 & 5092486 & 428946 & 7.0 & $1700 \mathrm{AD} ? / \mathrm{PHU}$ & SBD/SCL,TSL & $\mathrm{SC}$ & $43 / 71,162$ \\
\hline SSW 789 & 12-Jul & 863492 & 1131441 & 5092540 & 428929 & 7.0 & $1700 \mathrm{AD}$ ?/PHU & SBD?/TSL & SC & $51 / 95$ \\
\hline SSW 790 & 12-Jul & 863783 & 1131457 & 5092628 & 428931 & 7.0 & $1700 \mathrm{AD} ?$ & LSD & SC & 188 \\
\hline SSW 791 & 16-Jul & 865271 & 1132080 & 5093087 & 429107 & 7.0 & $1700 \mathrm{AD} / \mathrm{PHU}$ & SBD?/TSL & $\mathrm{SC}$ & $65 / 78$ \\
\hline SSW 792 & 16-Jul & 865346 & 1132441 & 5093114 & 429216 & 7.0 & $1700 \mathrm{AD}$ ? & SBD? & SC & 58 \\
\hline SSW 793 & 24-Jul & 864771 & 1131906 & 5092933 & 429058 & 5.0 & $1700 \mathrm{AD}$ ?/PHU? & SBD?/LSD & $\mathrm{SC}$ & $72 / 94$ \\
\hline SSW 794 & 24-Jul & 864462 & 1132051 & 5092841 & 429105 & 7.0 & $?$ & LSD & SC & 104 \\
\hline SSW 795 & 24-Jul & 864543 & 1131953 & 5092864 & 429075 & 7.0 & PHU & TSL & SC & 117 \\
\hline SSW 796 & 24-Jul & 864288 & 1131863 & 5092786 & 429050 & 7.0 & $1700 \mathrm{AD}$ & SBD? & SC & 32 \\
\hline SSW 797 & 25-Jul & 862979 & 1131118 & 5092380 & 428835 & 6.0 & $1700 \mathrm{AD} / \mathrm{PHU}$ & TSL/SBD? & SC & 41,76 \\
\hline SSW 798 & 25-Jul & 863051 & 1131091 & 5092402 & 428826 & 6.0 & $1700 \mathrm{AD} ? / \mathrm{PHU}$ & SBD? & $\mathrm{SC}$ & 70 \\
\hline SSW 799 & 25-Jul & 863509 & 1131153 & 5092542 & 428841 & 7.0 & $1700 \mathrm{AD} ?$ & SBD? & $\mathrm{SC}$ & 52 \\
\hline SSW 800 & 25-Jul & 863765 & 1131146 & 5092620 & 428836 & 7.0 & $?$ & & $\mathrm{SC}$ & \\
\hline SSW 801 & 30-Jul & 864480 & 1131635 & 5092842 & 428978 & 7.0 & $1700 \mathrm{AD}$ ? & SBD? & SC & 40 \\
\hline SSW 802 & 30-Jul & 865401 & 1132046 & 5093127 & 429095 & 5.0 & $1700 \mathrm{AD}$ ? & SBD? & $\mathrm{SC}$ & $43 ?$ \\
\hline SSW 803 & 30-Jul & 865454 & 1132130 & 5093144 & 429120 & 6.0 & $1964 ? / 1700 \mathrm{AD} / \mathrm{PHU}$ & TSL?/SBD?/LSD/SBD & SC & $7 ? / 60 / 74 / 82$ \\
\hline SSW 804 & 30-Ju] & 865541 & 1132253 & 5093171 & 429157 & 6.0 & $1964 ?$ & TSL & SC & 7 \\
\hline SSW 805 & 30-Jul & 865632 & 1132383 & 5093200 & 429195 & 7.0 & $1964 ?$ & TSL & $\mathrm{SC}$ & 17 \\
\hline SSW 806 & 30-Jul & 865602 & 1132527 & 5093192 & 429240 & 5.0 & $1964 ? / 1700 \mathrm{AD}$ & MSL/TSL & SC & $4 / 50$ \\
\hline SSW 807 & 30-Jul & 865740 & 1132504 & 5093234 & 429231 & 7.0 & $1964 ?$ & TSL? & $\mathrm{SC}$ & 20 \\
\hline SSW 808 & 30-Jul & 865835 & 1132724 & 5093265 & 429297 & 5.0 & $1964 ? / 1700 \mathrm{AD}$ & TSL/SBD & $\mathrm{SC}$ & $10 / 73$ \\
\hline SSW 809 & 30-Jul & 865968 & 1132605 & 5093305 & 429260 & 5.0 & $1700 \mathrm{AD} ?$ & SBD? & SC & 30 \\
\hline SSW 810 & 30-Jul & 866073 & 1132556 & 5093336 & 429244 & 5.0 & $?$ & & SC & \\
\hline SSW 811 & 30-Jul & 864816 & 1131392 & 5092942 & 428901 & 5.0 & $1700 \mathrm{AD}$ ? & SBD? & $\mathrm{SC}$ & 61 \\
\hline SSW 812 & 30-Jul & 865043 & 1131632 & 5093014 & 428972 & 7.0 & $1700 \mathrm{AD}$ & $\mathrm{SCL}$ & SC & 36 \\
\hline SSW 813 & 30-Jul & 864991 & 1131766 & 5092999 & 429014 & 7.0 & $1700 \mathrm{AD} / \mathrm{PHU}$ & TSL/SBD & $\mathrm{SC}$ & $31 / 83$ \\
\hline SSW 814 & 30-Jul & 864993 & 1131853 & 5093001 & 429040 & 5.0 & PHU & $\mathrm{SBD}$ & $\mathrm{SC}$ & 125 \\
\hline SSW 815 & 30-Jul & 865104 & 1131797 & 5093034 & 429022 & 7.0 & $1700 \mathrm{AD}$ & SBD? & SC & $37 ?, 43 ?$ \\
\hline SSW 816 & 30-Jul & 865185 & 1131831 & 5093059 & 429032 & 5.0 & $?$ & & SC & \\
\hline SSW 817 & 6-Aug & 862936 & 1131212 & 5092368 & 428864 & 7.0 & $1700 \mathrm{AD}$ & SBD? & SC & 67 \\
\hline SSW 818 & 6-Aug & 862894 & 1131497 & 5092358 & 428951 & 7.0 & $1700 \mathrm{AD}$ & SCL & SC & 75 \\
\hline SSW 819 & 6-Aug & 864313 & 1132578 & 5092800 & 429267 & 9.0 & $?$ & LSD & $\mathrm{SC}$ & 55 \\
\hline SSW 820 & 6-Aug & 864901 & 1132882 & 5092982 & 429354 & 10.0 & $?$ & LSD & $\mathrm{SC}$ & 70 \\
\hline SSW 821 & 6-Aug & 864715 & 1132815 & 5092925 & 429336 & 11.0 & $?$ & LSD & $\mathrm{SC}$ & $43 / 90$ \\
\hline SSW 822 & 6-Aug & 864272 & 1131771 & 5092780 & 429022 & 5.0 & $1700 \mathrm{AD} / \mathrm{PHU}$ & SBD?/SCL & $\mathrm{SC} / \mathrm{CB}$ & $53 / 90$ \\
\hline SSW 823 & 6-Aug & 864240 & 1131830 & 5092771 & 429040 & 6.0 & $1700 \mathrm{AD}$ ?/PHU & SBD?/TSL & $\mathrm{SC} / \mathrm{CB}$ & $45 / 141$ \\
\hline SSW 824 & 6-Aug. & 864136 & 1132173 & 5092743 & 429146 & 9.0 & $1700 \mathrm{AD}$ ? & LIS,SBD? & SC & 70 \\
\hline SSW 825 & 6-Aug & 864418 & 1132176 & 5092829 & 429144 & 7.0 & $1700 \mathrm{AD} ?$ & TSL?,SBD? & SC & 90 \\
\hline SSN 826 & 6-Aug & 859815 & 1126302 & 5091372 & 427398 & 9.0 & PHU & & SC & \\
\hline SSN 827 & 6-Aug & 859621 & 1126194 & 5091311 & 427367 & 13.0 & PHU & & $\mathrm{SC}$ & \\
\hline SSW 828 & 7-Aug & 861047 & 1130071 & 5091782 & 428534 & 5.0 & $1700 \mathrm{AD} / \mathrm{PHU}$ & SBD?/TSL/SBD & $\mathrm{SC}$ & $69 / 92$ \\
\hline SSW 829 & 7-Aug & 861185 & 1130096 & 5091824 & 428541 & 7.0 & $1700 \mathrm{AD}$ ? & SBD? & SC & 60 \\
\hline SSW 830 & 7-Aug & 860921 & 1129953 & 5091743 & 428500 & 7.0 & $1700 \mathrm{AD} / \mathrm{PHU}$ & $\mathrm{SCL} / \mathrm{SBD}$ ? & $\mathrm{SC}$ & $77 / 140$ \\
\hline SSW 831 & 7-Aug & 860895 & 1129725 & 5091733 & 428430 & 7.0 & $1700 \mathrm{AD} / \mathrm{PHU}$ & SBD?/TSL/SBD & $\mathrm{SC}$ & $56 / 83 / 130$ \\
\hline \multicolumn{11}{|c|}{ 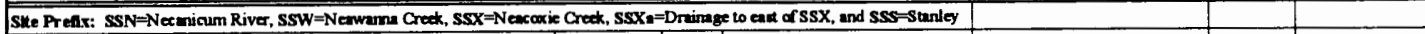 } \\
\hline \multicolumn{11}{|c|}{ Lake, SSB= Promerude (Bourdwalk), SSG= Seaside golf course } \\
\hline \multicolumn{11}{|c|}{ State Fime: North American D wum 1927, northem Oregan, in U.S. murvey feet } \\
\hline \multicolumn{11}{|c|}{ 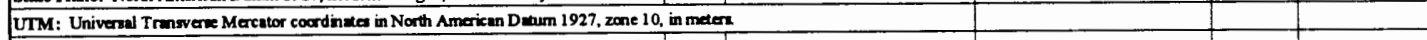 } \\
\hline \multicolumn{11}{|c|}{ Sur face Elevetion: CH2M HIII 1973 D wum to the newed extropoluted one foot $(+1 \mathrm{ft})$. } \\
\hline \multicolumn{11}{|c|}{ Event Record: 1964, 1700 AD PHU (Prethiscoric Unknown) } \\
\hline \multicolumn{11}{|c|}{ Record Type: TSL=T sumami-deposited and hya, MSL=Mud and sand layer, SL= Sand leryer. } \\
\hline \multicolumn{11}{|c|}{ SBD=Subsidence burial deposit LSD=L andslide deposit, LS=Liquified irtruded and, and SCL $=S$ and capping bya, } \\
\hline Veriffation: & SC=Subart & Care, ST=So & Trench, and C & =Cutbank. & & & & & & \\
\hline Core Depth: & Subsurface d & th to TSLCSL & SL kowr conte & buried peat an & Indadide $m$ & il upper & conted, in centimeters. & & & \\
\hline
\end{tabular}




\begin{tabular}{|c|c|c|c|c|c|c|c|c|c|c|}
\hline Site & Date & State & Plane & UTM & UTM & Surf. & Event & Record & Veri & Core \\
\hline Number & 1996 & Northing & Easting & Northing & Easting & Elev. & Recard & Type & & Depth \\
\hline SSW 832 & 7-Aug & 860751 & 1129530 & 5091687 & 428372 & 7.0 & $1700 \mathrm{AD} / \mathrm{PHU}$ & SCLITSLISBD? & $\mathrm{SC}$ & $42 / 92 / 127$ \\
\hline SSW 833 & 7-Aug & 861533 & 1130863 & 5091938 & 428771 & 5.0 & $1700 \mathrm{AD}$ & $\mathrm{SCL}$ & $\mathrm{SC}$ & 43 \\
\hline SSW 834 & 7-Aug & 861662 & 1130912 & 5091977 & 428785 & 6.0 & $1700 \mathrm{AD}$ ? & SCL? & $\mathrm{SC}$ & 56 \\
\hline SSW 835 & 7-Aug & 861807 & 1130923 & 5092022 & 428787 & 7.0 & $?$ & & $\mathrm{SC}$ & \\
\hline SSW 836 & 7-Aug & 861961 & 1130929 & 5092069 & 428787 & 6.5 & $1700 \mathrm{AD} ?$ & SBD? & SC & 72 \\
\hline SSW 837 & 8-Aug & 861870 & 1130964 & 5092041 & 428799 & 7.0 & $1700 \mathrm{AD} ?$ & SBD? & SC & 42 \\
\hline SSW 838 & 8-Aus & 861972 & 1130878 & 5092071 & 428771 & 7.0 & $1700 \mathrm{AD} ?$ & SBD? & $\mathrm{SC}$ & 63 \\
\hline SSW 839 & 8-Aug & 862006 & 1131005 & 5092083 & 428810 & 6.0 & $1700 \mathrm{AD}$ & SBD? & $\mathrm{SC}$ & 40 \\
\hline SSW 840 & 8-Aug & 862163 & 1131055 & 5092131 & 428824 & 7.0 & $?$ & & $\mathrm{SC}$ & \\
\hline SSW 841 & 8-Aug & 862176 & 1131102 & 5092136 & 428838 & 7.0 & $1700 \mathrm{AD}$ & SBD? & SC & 52 \\
\hline SSW 842 & 8-Aug & 862279 & 1131134 & 5092167 & 428847 & 7.0 & $1700 \mathrm{AD}$ & SBD? & $\mathrm{SC}$ & 60 \\
\hline SSW 843 & 8-Aug & 862464 & 1131181 & 5092224 & 428859 & 7.0 & $1700 \mathrm{AD}$ & SBD & $\overline{\mathrm{SC}}$ & 38 \\
\hline SSW 844 & 8-Aug & 862734 & 1131162 & 5092306 & 428851 & 5.0 & $1700 \mathrm{AD}$ & SBD? & $\mathrm{SC}$ & 50 \\
\hline SSW 845 & 8-Aug & 864710 & 1132176 & 5092917 & 429141 & 7.0 & $?$ & & SC & \\
\hline SSW 846 & 8-Aug & 864903 & 1132239 & 5092977 & 429158 & 7.0 & $1700 \mathrm{AD}$ & $\mathrm{SBD}$ & SC & 40 \\
\hline SSW 847 & 9-Aug & 866631 & 1132902 & 5093509 & 429344 & 5.0 & $1700 \mathrm{AD}$ & SCL & SC & 57 \\
\hline SSW 848 & 9-Aug & 868019 & 1132038 & 5093924 & 429068 & 5.0 & PHU & SBD & SC & 180 \\
\hline SSXa 849 & 13-Aug & 875137 & 1133262 & 5096103 & 429374 & 6.0 & 1964 & TSL & SC & 12 \\
\hline SSXa 850 & 13-Aug & 875015 & 1133214 & 5096066 & 429361 & 7.0 & $1964 / 1700 \mathrm{AD} ?$ & SL/SBD? & SC,ST & 9,50 \\
\hline SSXa 851 & 13-Aug & 874925 & 1133308 & 5096039 & 429390 & 6.0 & 1964 & TSL & SC & 14 \\
\hline SSXa 852 & 13-Aug & 874910 & 1133232 & 5096034 & 429367 & 5.0 & 1964 & TSL & SC & 14 \\
\hline SSXa 853 & 13-Aug & 874919 & 1133218 & 5096036 & 429363 & 5.0 & $1964 / ?$ & TSL? $/ ?$ & SC & $12 / 45$ \\
\hline SSXa 854 & 13-Aug & 874916 & 1133178 & 5096035 & 429351 & 6.0 & 1964/1700 AD? & TSL/SCL? & $\mathrm{SC}$ & $12 / 33$ \\
\hline SSXa 855 & 13-Aug & 875286 & 1133096 & 5096147 & 429322 & 7.0 & $1964 / 1700 \mathrm{AD} ?$ & TSL/SCL & $\mathrm{SC}$ & $11 / 50$ \\
\hline SSXa 856 & 13-Aug & 875288 & 1133163 & 5096148 & 429342 & 7.0 & $1964 / 1700 \mathrm{AD} ? / ?$ & TSL/SBD/SCL & SC & $7 / 40 / 60$ \\
\hline SSXa 857 & 13-Aug & 875415 & 1133218 & 5096187 & 429358 & 7.0 & $?$ & & SC & \\
\hline SSXa 858 & 13-Aug & 874681 & 1133237 & 5095964 & 429371 & 5.0 & 1964 & TSI, & $\mathrm{SC}$ & $8 ?$ \\
\hline SSN 859 & 14-Aug & 870509 & 1131038 & 5094673 & 428740 & 7.0 & 1964 & TSL & $\mathrm{SC}$ & 24 \\
\hline SSN 860 & 14-Aug & 870478 & 1131012 & 5094663 & 428733 & 7.0 & 1964 & MSL & SC & $14-22$ \\
\hline SSN 861 & 14-Aug & 870185 & 1130851 & 5094572 & 428686 & 7.0 & 1964 & TSL & $\mathrm{SC}$ & 16 \\
\hline SSN 862 & 14-Aug & 869934 & 1130683 & 5094494 & 428637 & 7.0 & 1964 & TSL & $\mathrm{SC}$ & 17 \\
\hline SSN 863 & 14-Aug & 870056 & 1130662 & 5094531 & 428630 & 7.0 & 1964 & MSL? & SC & $4-22$ \\
\hline SSN 864 & 14-Aug & 870480 & 1130944 & 5094663 & 428712 & 7.0 & 1964 & MSL & SC,ST & $4-12$ \\
\hline SSN 865 & 14-Aug & 870524 & 1130917 & 5094676 & 428703 & 7.0 & 1964 & TSL & SC & 8 \\
\hline SSS 866 & 14-Aug & 872496 & 1134637 & 5095312 & 429818 & 3.0 & $1700 \mathrm{AD} ?$ & SL & $\mathrm{SC}$ & 56 \\
\hline SSS 867 & 14-Aug & 872335 & 1134615 & 5095263 & 429812 & 3.0 & $1700 \mathrm{AD} ?$ & SCL & $\mathrm{SC}$ & 65 \\
\hline SSS 868 & 14-Aug & 872237 & 1134534 & 5095232 & 429789 & 3.0 & $1700 \mathrm{AD} ?$ & SL & $\mathrm{SC}$ & 83 \\
\hline SSN 869 & 15-Aug & 871013 & 1131715 & 5094833 & 428942 & 9.0 & 1964 & TSL & SC & 15 \\
\hline SSN 870 & 15-Aug & 871410 & 1131860 & 5094955 & 428982 & 9.0 & $19 \overline{64}$ & TSL & SC & 31 \\
\hline SSN 871 & \begin{tabular}{|l|}
$15-$ Aug \\
\end{tabular} & 870805 & 1131037 & 5094763 & 428737 & 7.0 & 1964 & TSL & $\overline{\mathrm{SC}}$ & 26 \\
\hline SSS 872 & 15-Aug & 870349 & 1134293 & 5094655 & 429733 & 5.0 & PHU? & & SC & \\
\hline SSS 873 & 15-Aug & 870724 & 1134431 & 5094770 & 429771 & 5.0 & PHU? & & SC & \\
\hline SSS 874 & 15-Aug & 871094 & 1134518 & 5094884 & 429794 & 3.0 & PHU? & SL & SC & 45 \\
\hline SSS 875 & 15-Aug & 871529 & 1134459 & 5095016 & 429772 & 5.0 & PHU? & SL & $\mathrm{SC}$ & 50 \\
\hline SSS 876 & 15-Aug & 870014 & 1133851 & 5094548 & 429601 & 5.0 & PHU? & SL & SC & 62 \\
\hline SSN 877 & 16-Aug & 862573 & 1129242 & 5092239 & 428268 & 7.0 & PHU? & & SC & \\
\hline SSN 878 & 16-Aug & 862531 & 1129335 & 5092227 & 428296 & 5.0 & $1964 ?$ & TSL & SC & 5 \\
\hline SSS 879 & 22-Aug & 872881 & 1134513 & 5095428 & 429776 & 3.0 & $1700 \mathrm{AD}$ & TSL & SC & 54 \\
\hline SSS 880 & 22-Aug & 873010 & 1134592 & 5095468 & 429799 & 3.0 & $1700 \mathrm{AD}$ & TSL & $\mathrm{SC}$ & 70 \\
\hline SSS 881 & 22-Aug & 873119 & 1134483 & 5095500 & 429765 & 3.0 & $1700 \mathrm{AD}$ & TSL & SC & 64 \\
\hline SSN 882 & 22-Aug & 863916 & 1129822 & 5092654 & 428432 & 5.0 & $1964 / 1700 \mathrm{AD} ?$ & $\mathrm{TSL} / \mathrm{SBD}$ & SC & $4 / 80$ \\
\hline SSN 883 & 22-Aug & 863919 & 1129876 & 5092655 & 428448 & 5.0 & 1964 & TSL & SC & 12 \\
\hline SSN 884 & 22-Aug & 863908 & 1129786 & 5092651 & 428421 & 5.0 & $1700 \mathrm{AD} ?$ & TSL & $\mathrm{SC}$ & 71 \\
\hline SSS 885 & 22-Aug & 869415 & 1133985 & 5094367 & 429648 & 5.0 & PHU & LIS & SC & \\
\hline SSS 886 & 22-Aug & 869423 & 1133821 & 5094368 & 429598 & 5.0 & PHU & LIS & SC & 36 \\
\hline SSS 887 & 22-Aug & 869435 & 1133755 & 5094371 & 429578 & 5.0 & PHU & LIS & SC & 60 \\
\hline SSS 888 & 22-Aug & 869446 & 1133677 & 5094374 & 429554 & 5.0 & PHU & LIS & SC & 50 \\
\hline SSS 889 & 23-Aug & 869511 & 1133830 & 5094395 & 429600 & 5.0 & PHU & LIS & $\mathrm{SC}$ & 55 \\
\hline SSW 890 & 23-Aug & 860563 & 1129247 & 5091627 & 428288 & 7.0 & $?$ & & $\mathrm{SC}$ & \\
\hline \multicolumn{11}{|c|}{ 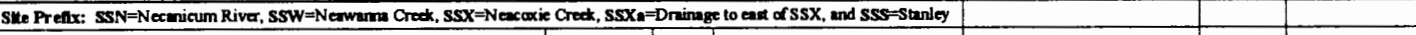 } \\
\hline \multicolumn{11}{|c|}{ Lake, SSE= Promenade (Boardwalk), SSG= Searide golf caurze. } \\
\hline \multicolumn{11}{|c|}{ Stute Pine: North American D mum 1927, northem Oregon, in U.S. murvey feet. } \\
\hline \multicolumn{11}{|c|}{ UTM: Univeral Trensverse Mercator coordindes in North American Datum 1927, zone 10, in meters } \\
\hline \multicolumn{11}{|c|}{ Surfince Elevertion: CH2M HIIL 1973 D mum to the newrest extropolisted one foot $(+1 \mathrm{ft})$. } \\
\hline \multicolumn{11}{|c|}{ Event Record: 1964, 1700 AD, PHU (Prehistaric Unknown) } \\
\hline \multicolumn{11}{|c|}{ Record Type: TSL=T sunami-deporited and hyer, MSL=Mud and sand layos, SL= Send laye, } \\
\hline \multicolumn{11}{|c|}{ 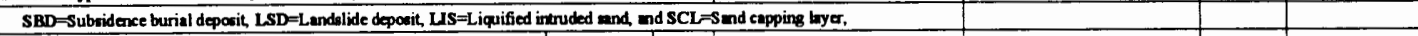 } \\
\hline Verification: & $\mathrm{SC}=$ Subsurac & eCore, $\mathrm{ST}=\mathrm{S}$ & Trench, and C & Cutbank. & & & & & & \\
\hline Core Depth: & Subsurface dq & th to TSL/CS & SL lower conts & buried peat & nddide $m$ & 1 u & Hact. in centimeters. & & & \\
\hline
\end{tabular}




\section{APPENDIX C}

GOUGE CORE LOGS 
Core Log Legend

Necanicum River (SSN)

159

$731,732,737-740$

159

741-750, 758-759

160

760-761, 826-827

161

859-865, 869-871, 877-878

162

882-884

163

Neacoxie Creek (SSX)

164

$751-754,769-774$

164

Drainage to the east of Neacoxie Creek (SSXa) 165

849-858 165

Stanley Lake (SSS) 166

733-734, 866-868, 872

166

873-876, 879, 880

167

881, 885-889

168

Neawanna Creek (SSW)

169

712-723

169

724-729

170

$730,735-736,755-757$

171

762-768, 775-779

172

780-785

173

786-791

174

792-797

175

798-803

176

804-809

177

810-815

178

816-821

179

822-825, 828-829

180

830-835

181

836-841

182

842-847

183

848,890

184 


\section{Core Log Legend}

$\begin{array}{llll}\text { peat } & \text { sand } & \text { mobble } \\ \text { muddy peat } & & \end{array}$

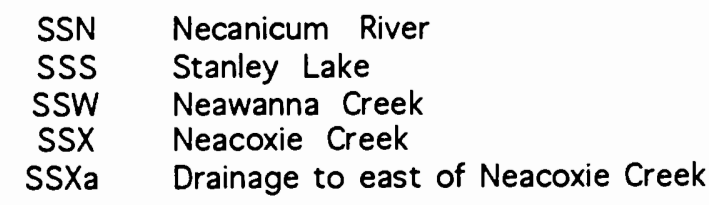

\begin{tabular}{|c|c|c|c|c|c|}
\hline$b$ & barren & $f$ & fining upward & $p$ & pebble \\
\hline c & coarse & $\mathrm{g}$ & gradual & pe & peaty \\
\hline$c d$ & core drag & i & intruded/irregular & $r$ & rooted \\
\hline$c h$ & charcoal & 1 & layer $(>5 \mathrm{~mm})$ & R C & Radiocarbon sample \\
\hline $\mathrm{cl}$ & clean & la & lamination $(<5 \mathrm{~mm})$ & re & reduced \\
\hline co & cobble & $\mathrm{m}$. & missing section & s & sharp \\
\hline cont. & continued & $\mathrm{mu}$ & muddy & sa & sandy \\
\hline$d$ & dense & 0 & organic debris & $w$ & wood fragments \\
\hline EOC & end of core & ox & oxidized & & \\
\hline
\end{tabular}




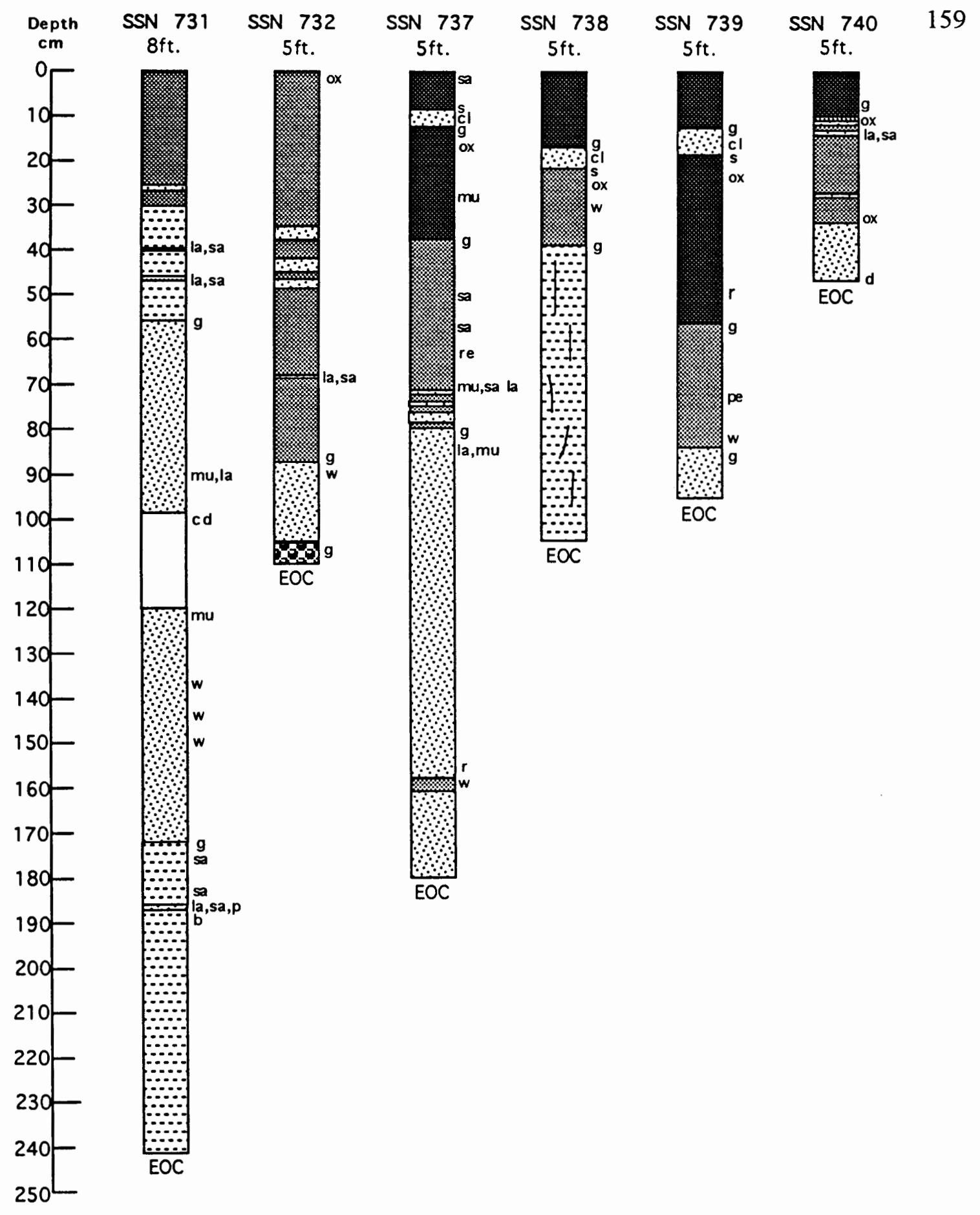



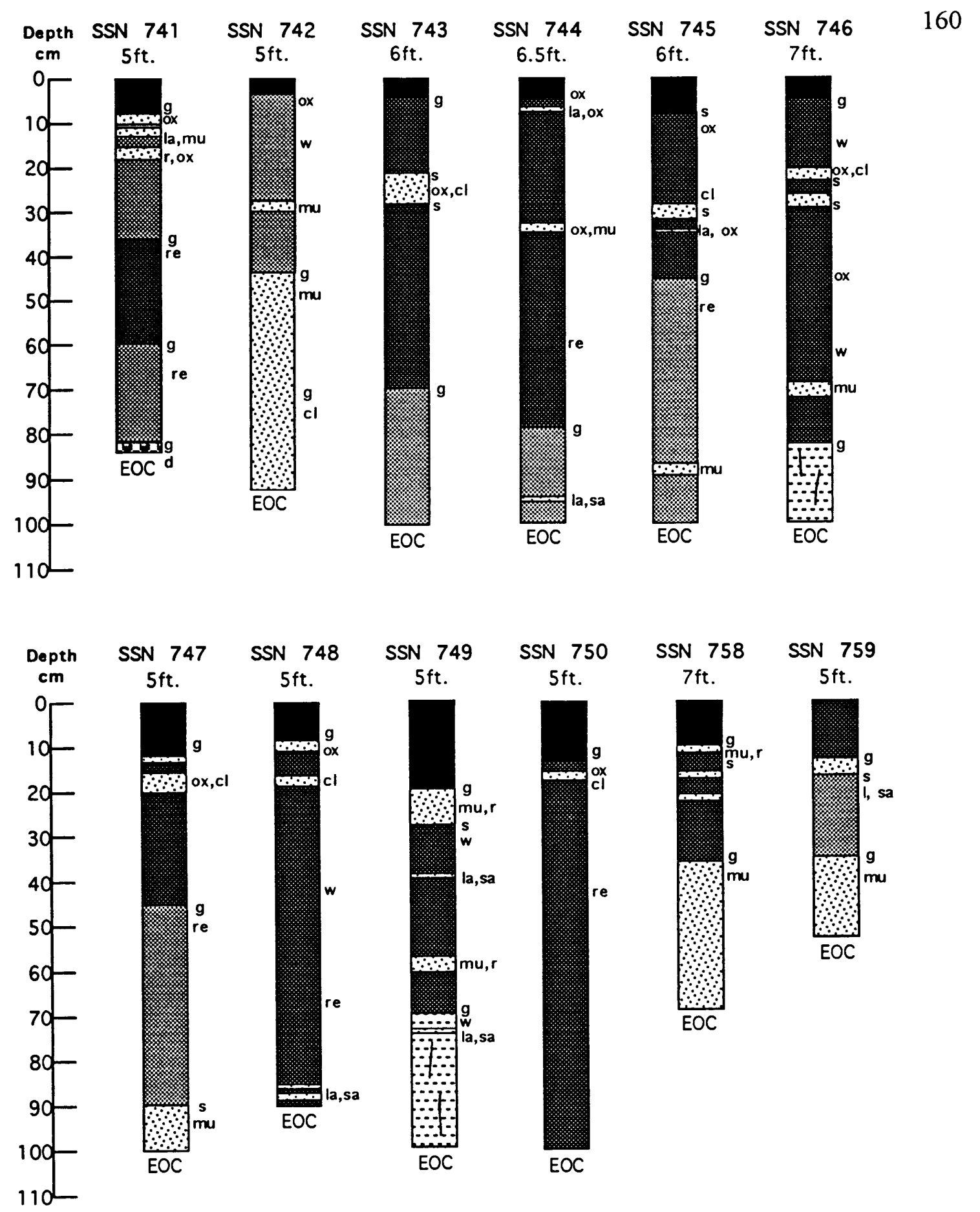


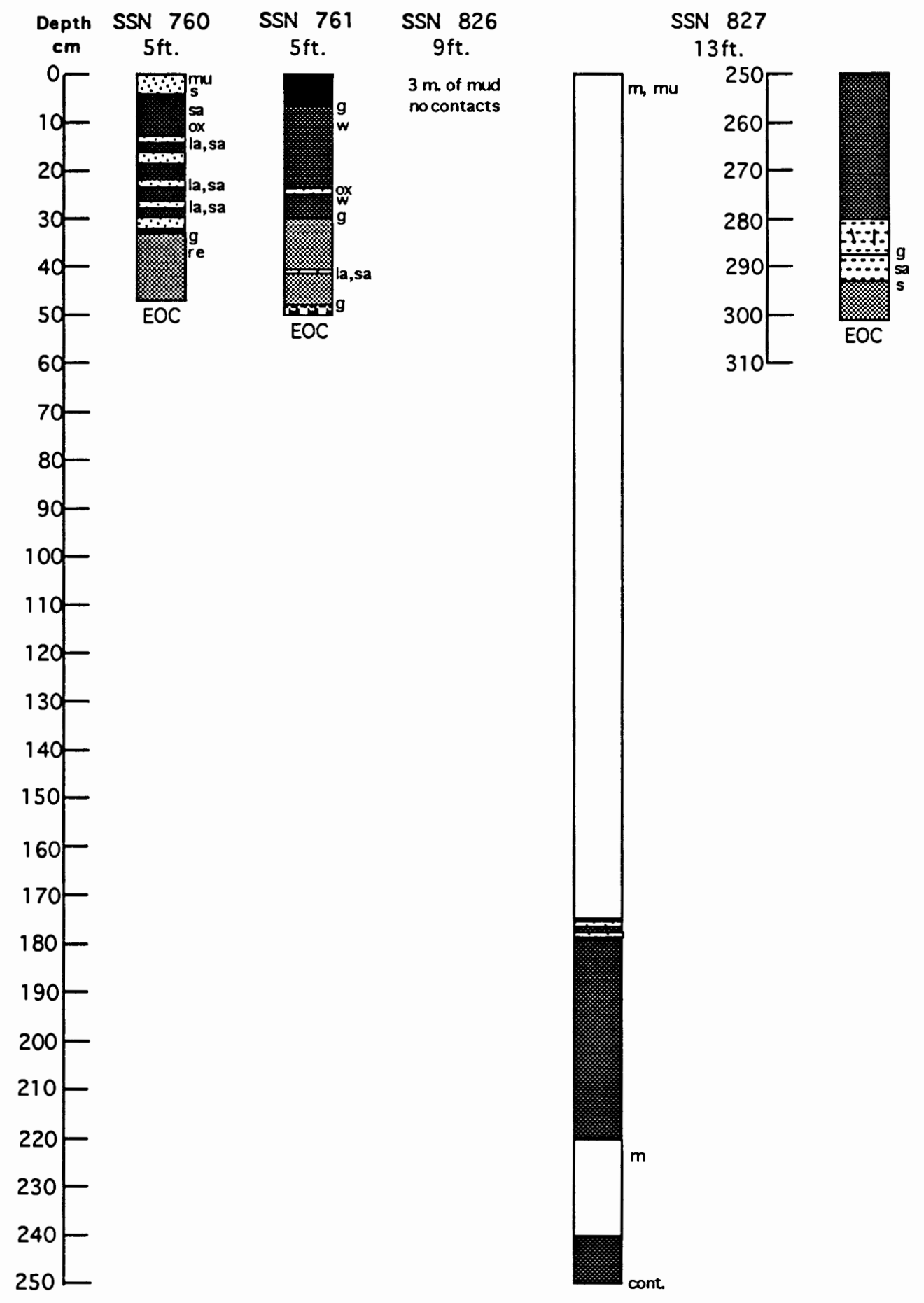



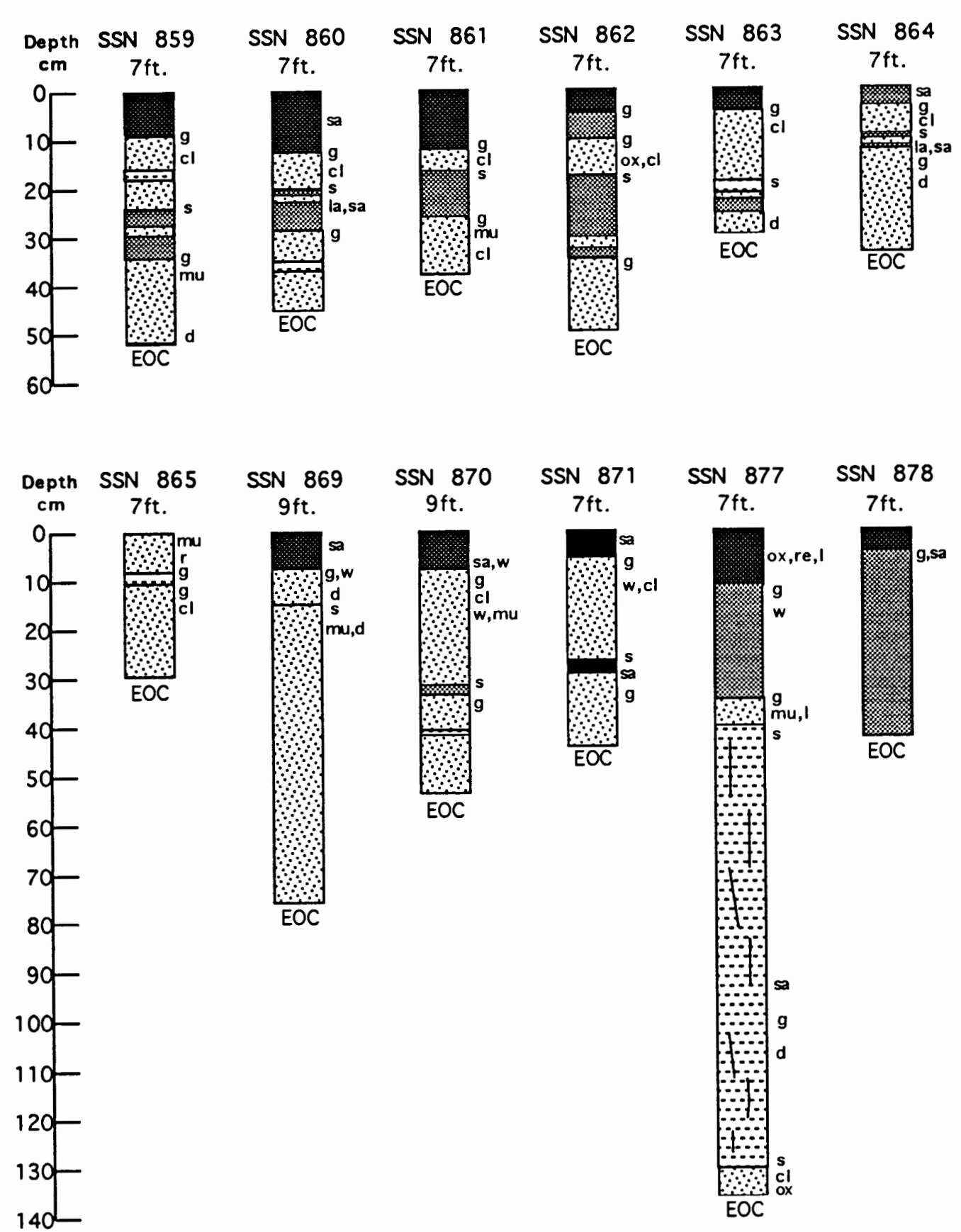


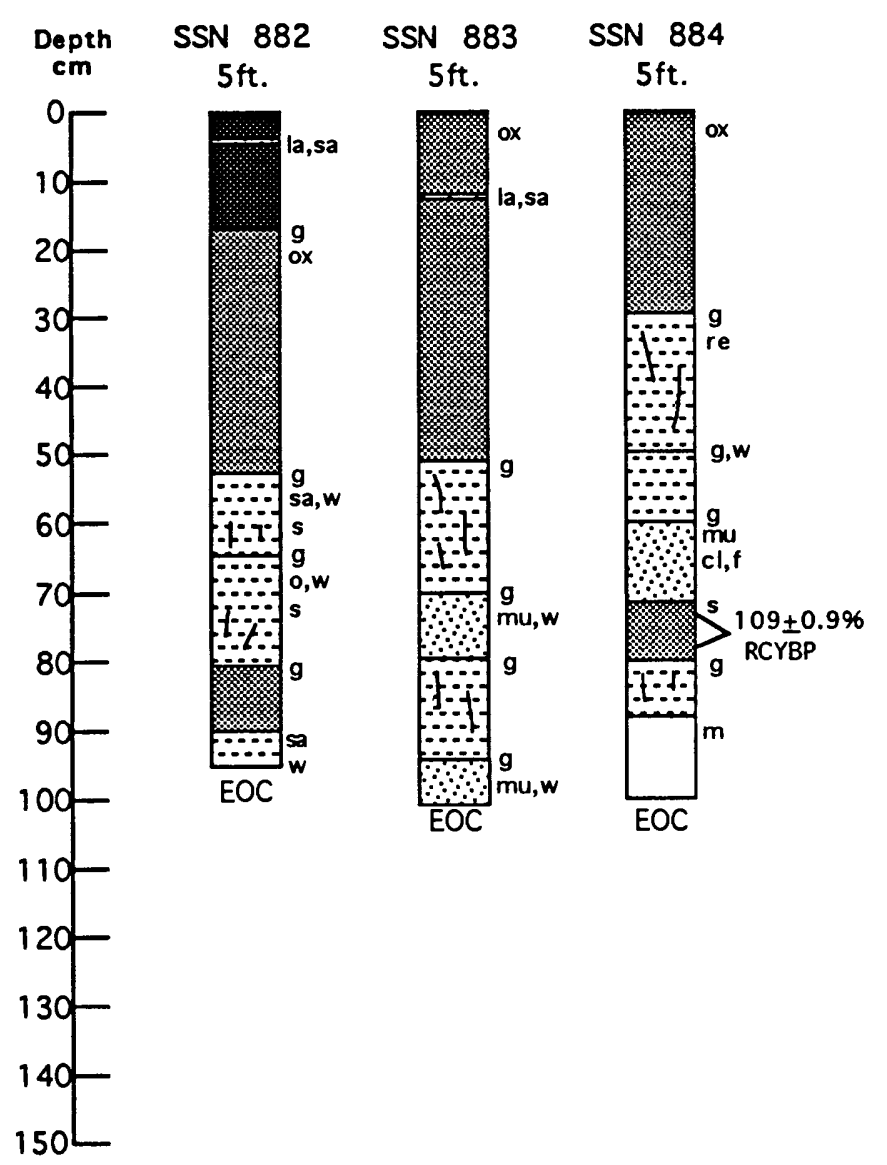



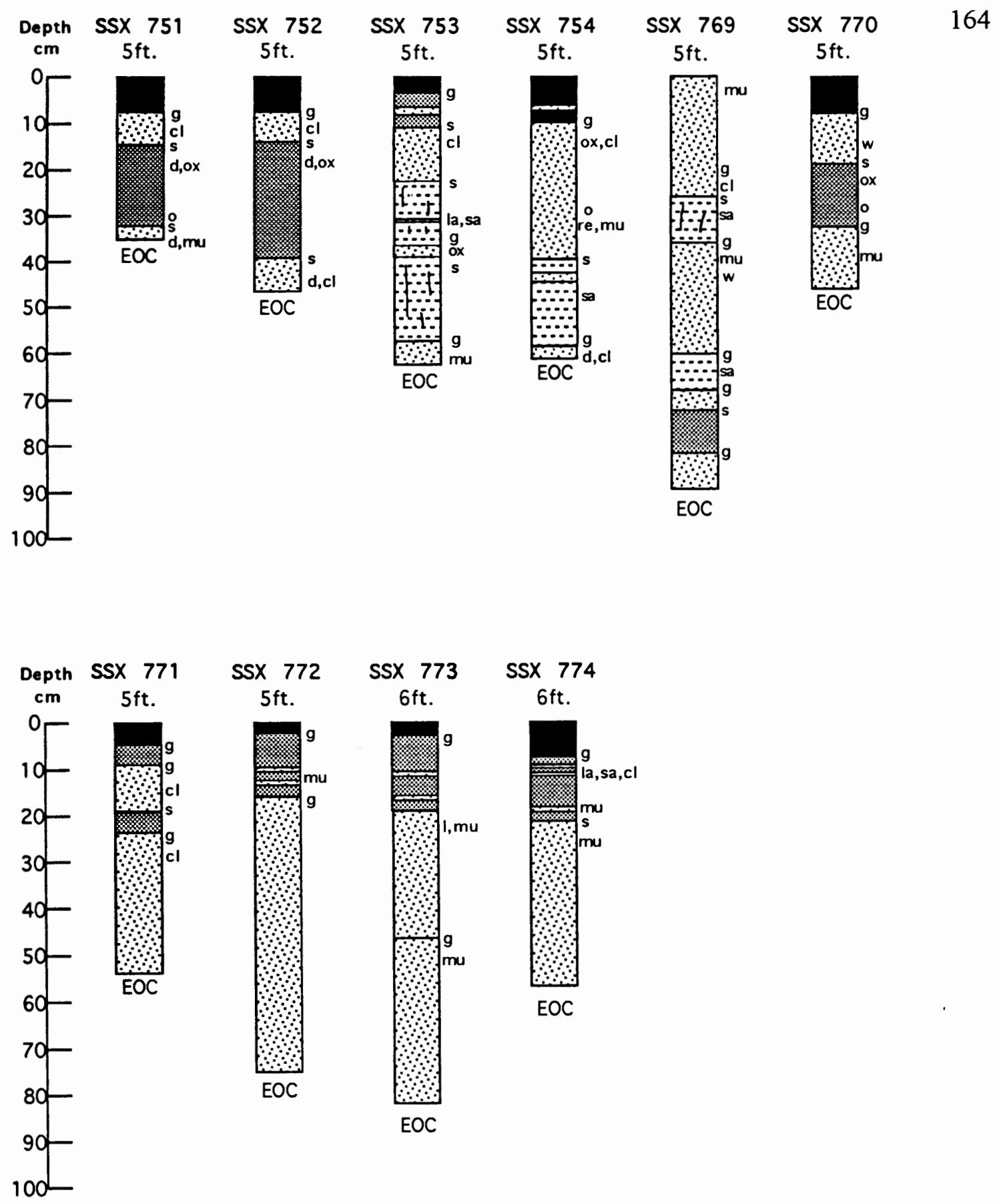

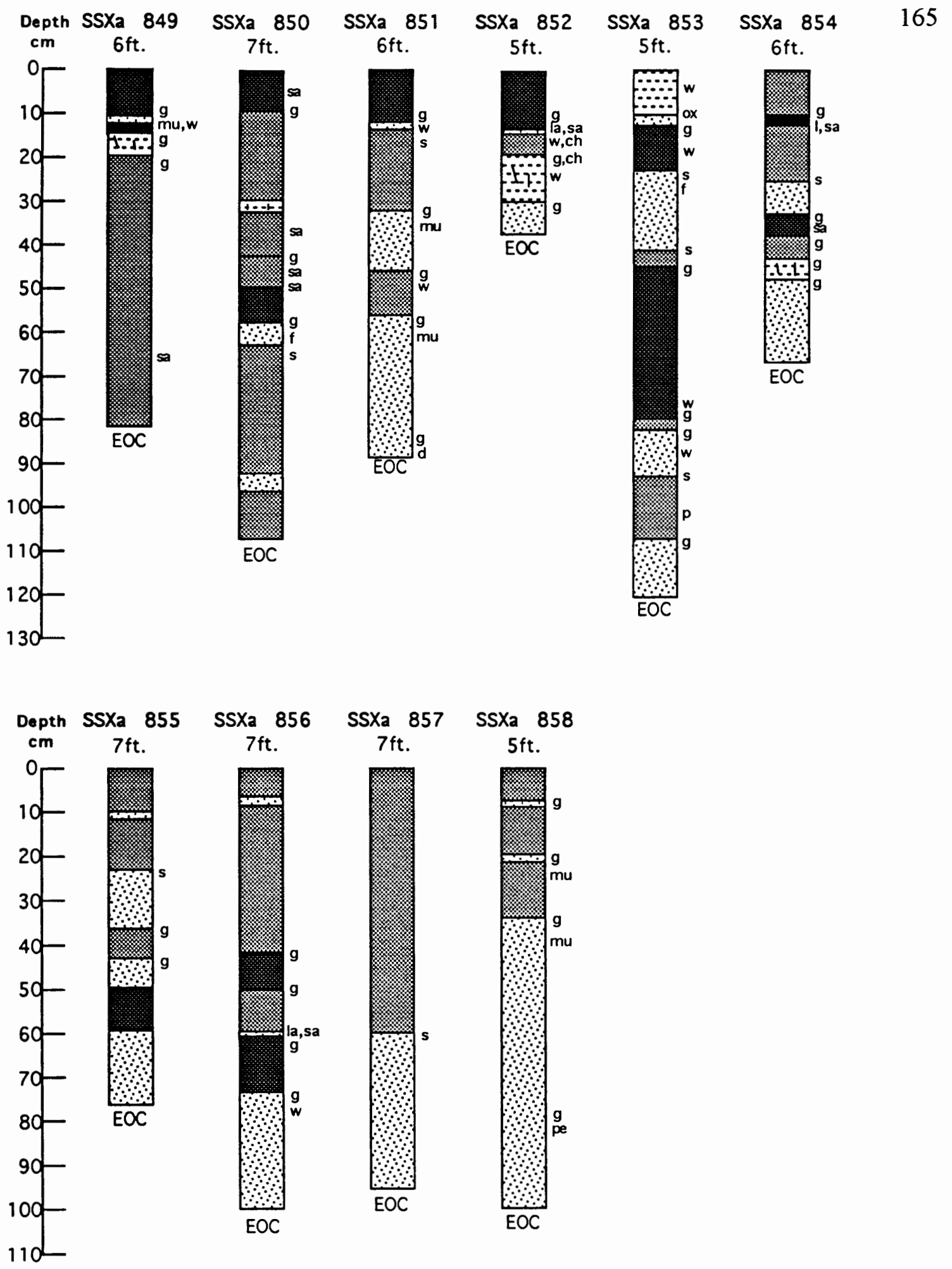


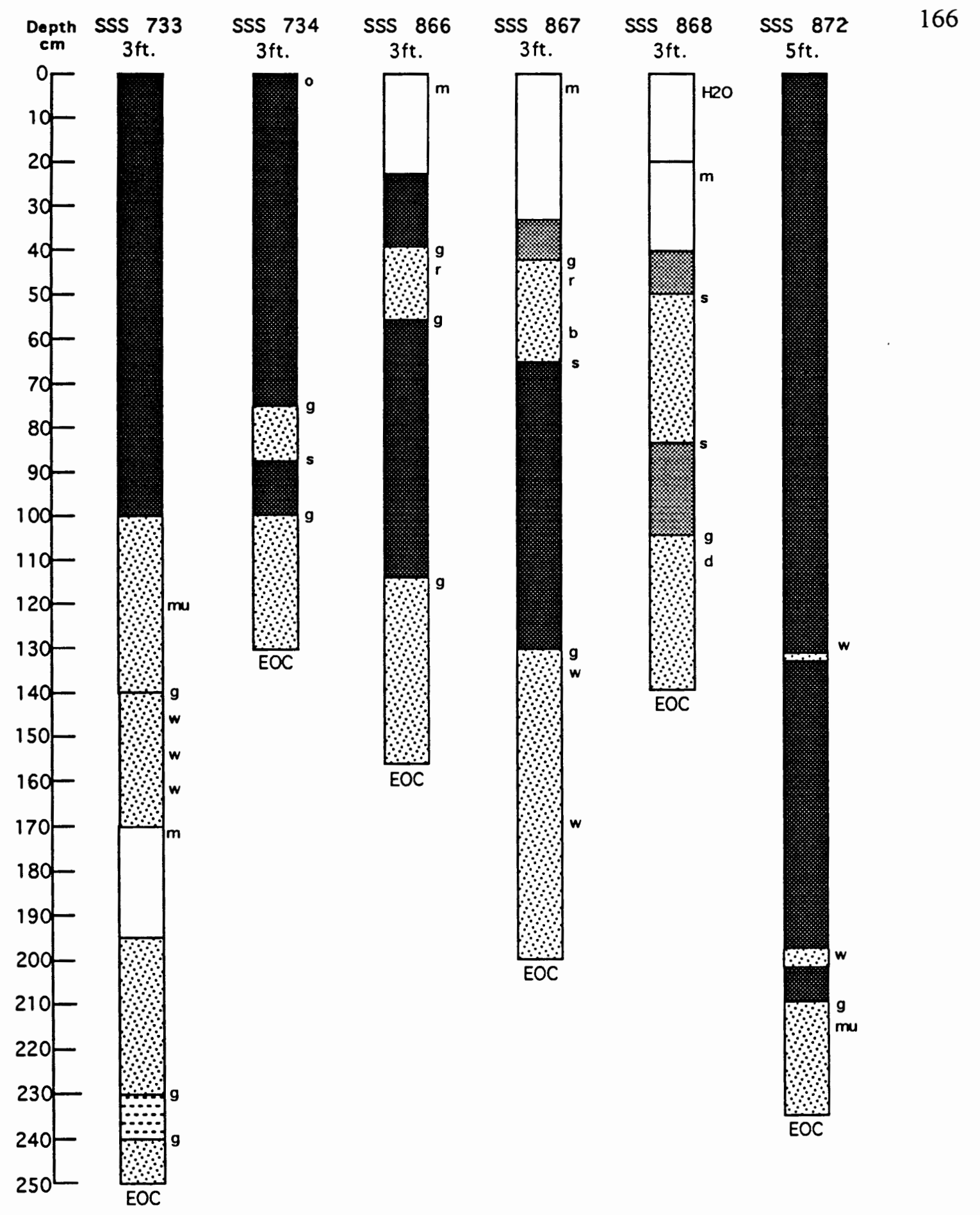




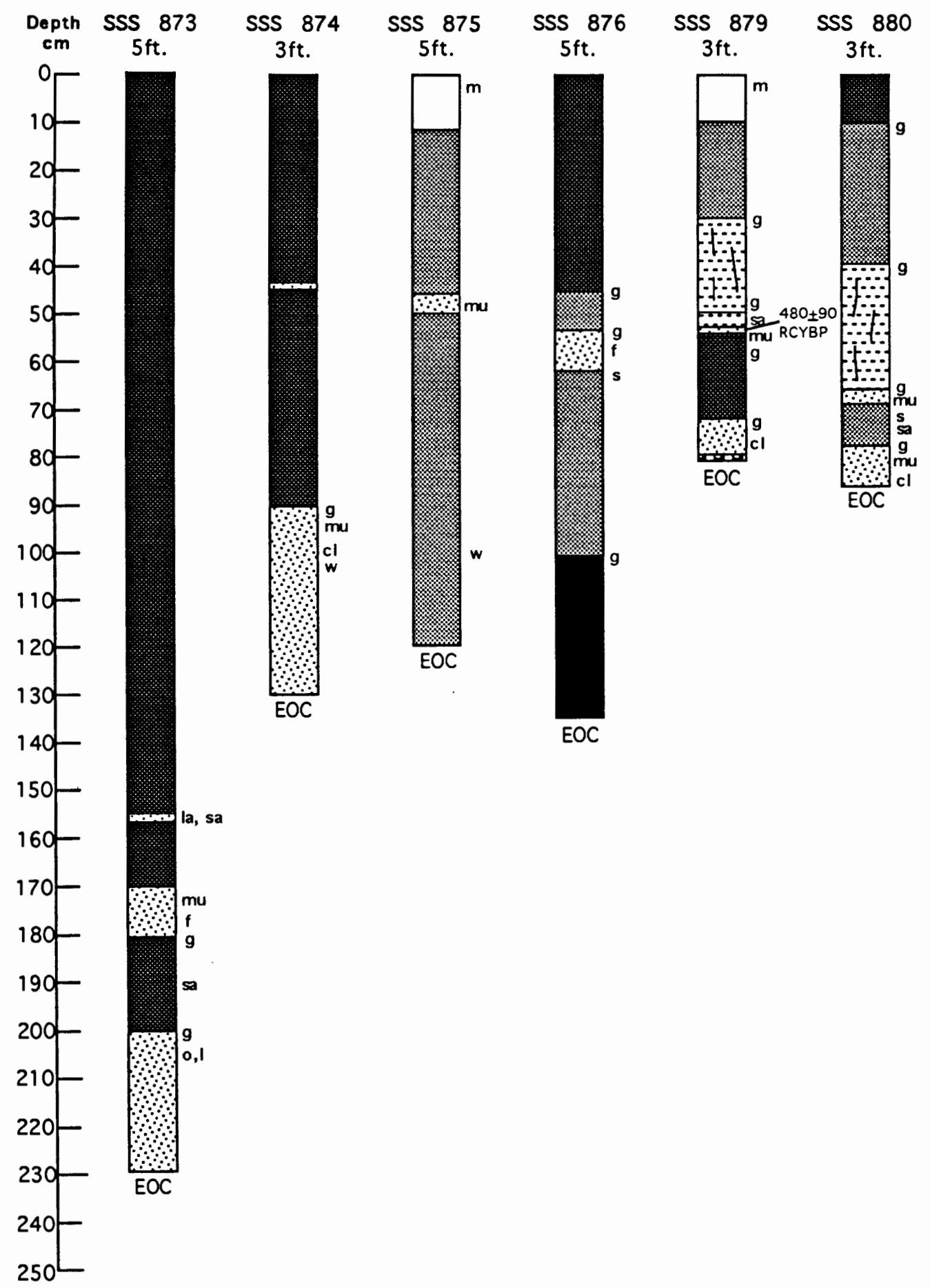




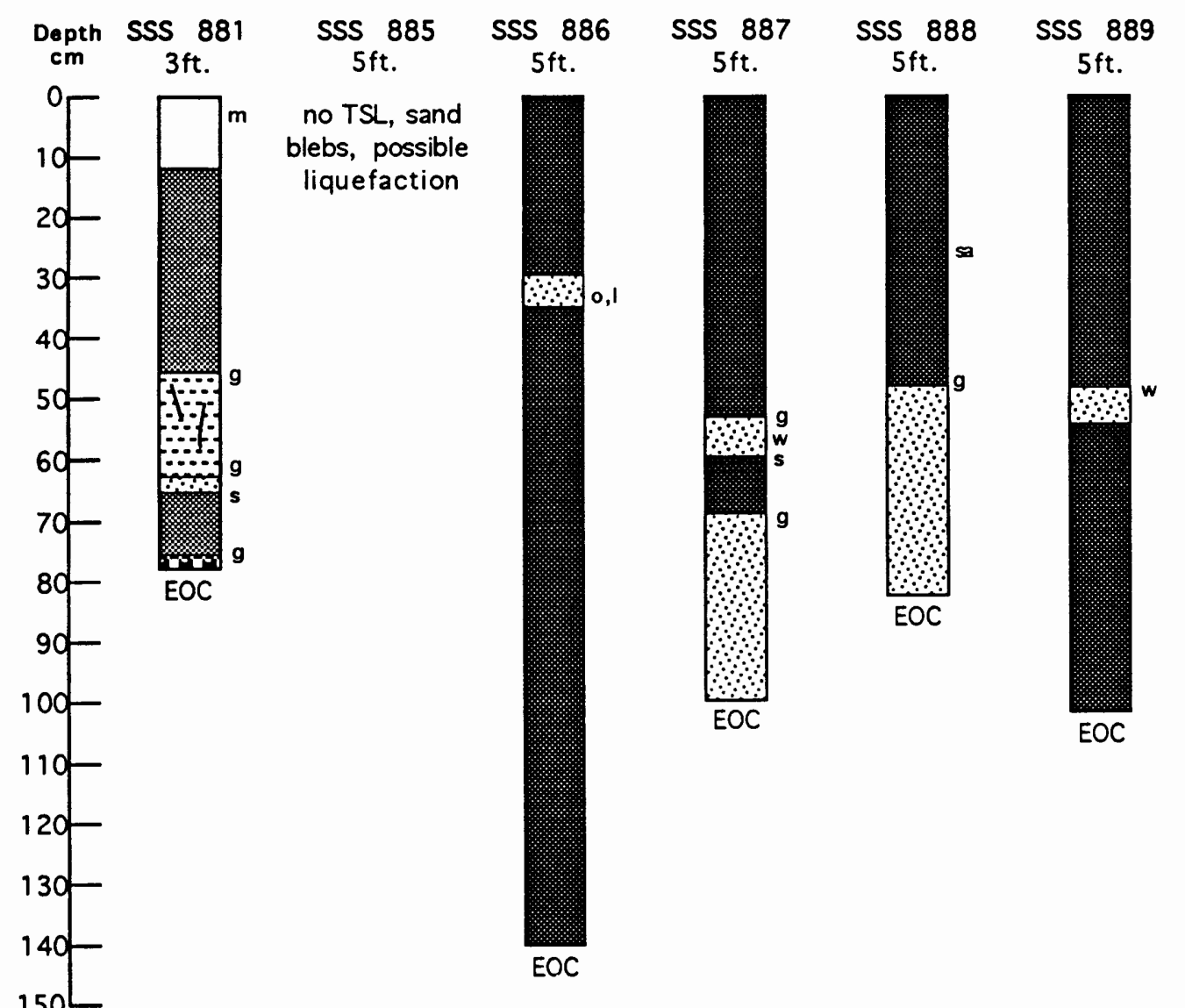



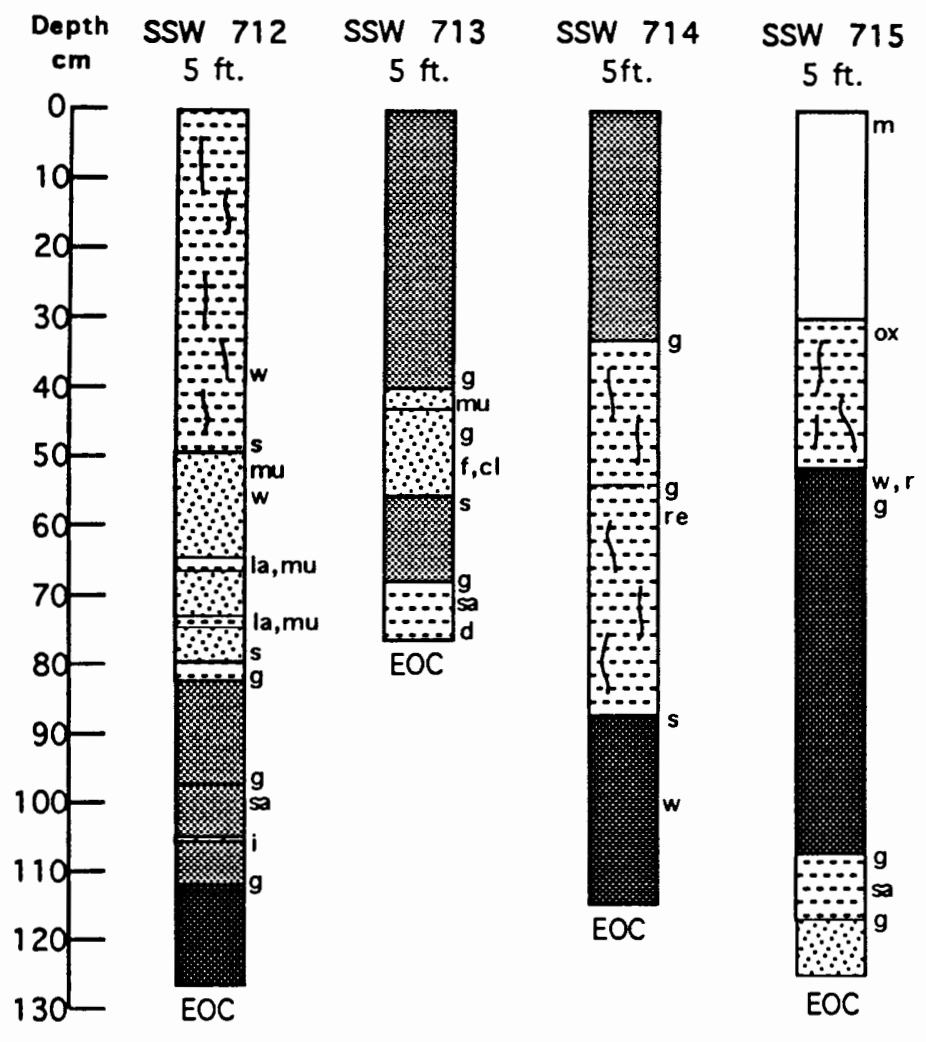

SSW 716 SSW 717

169
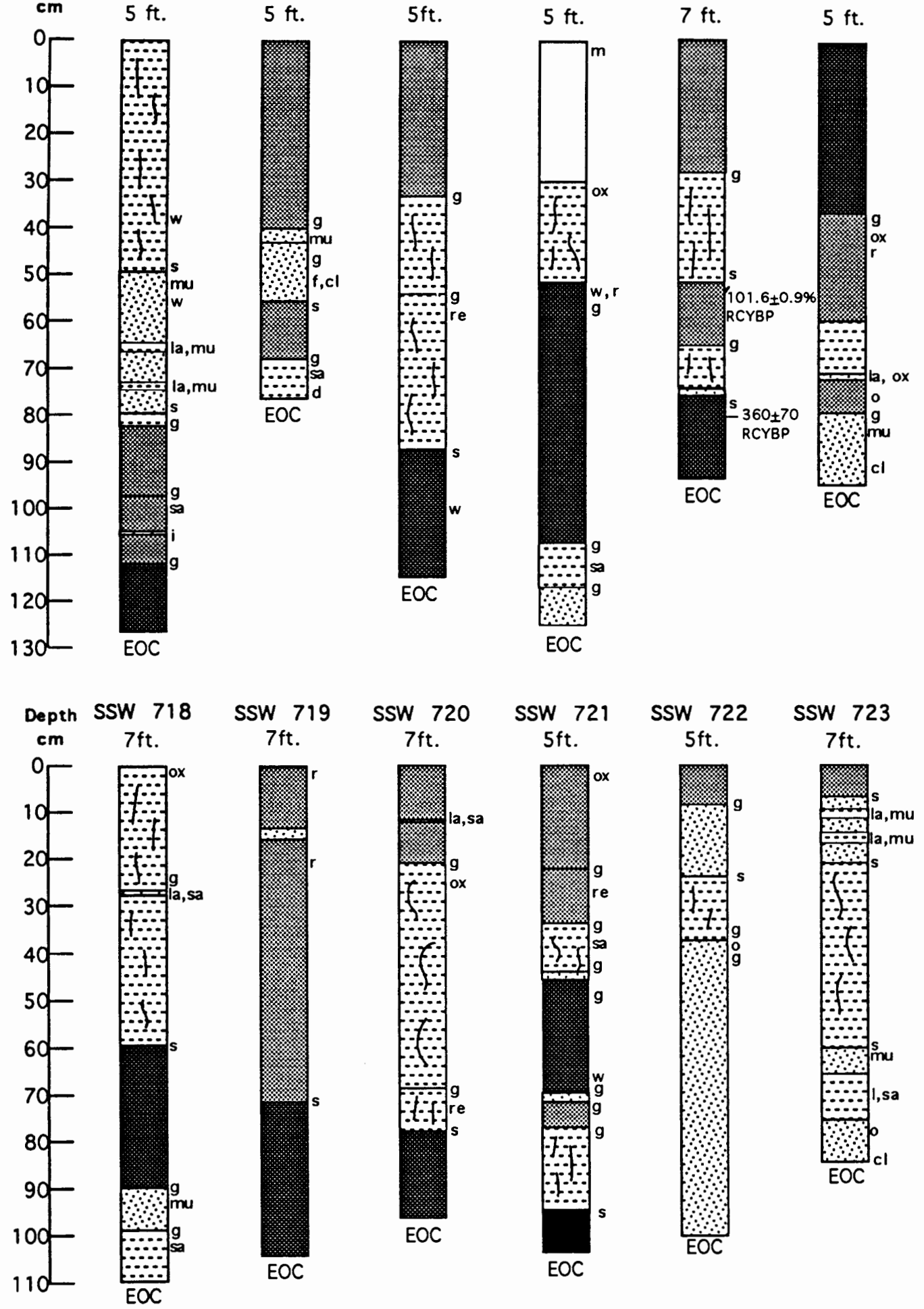


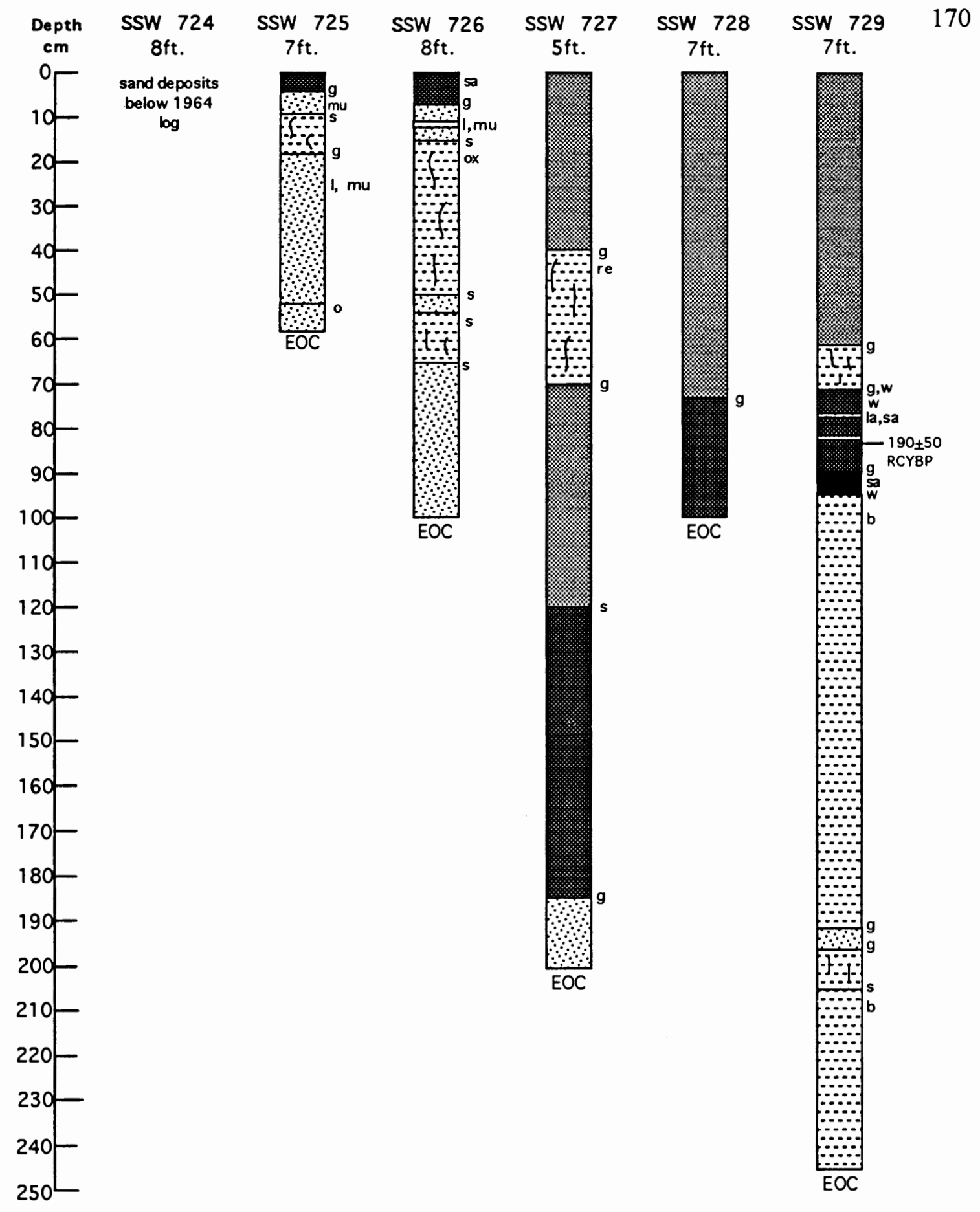




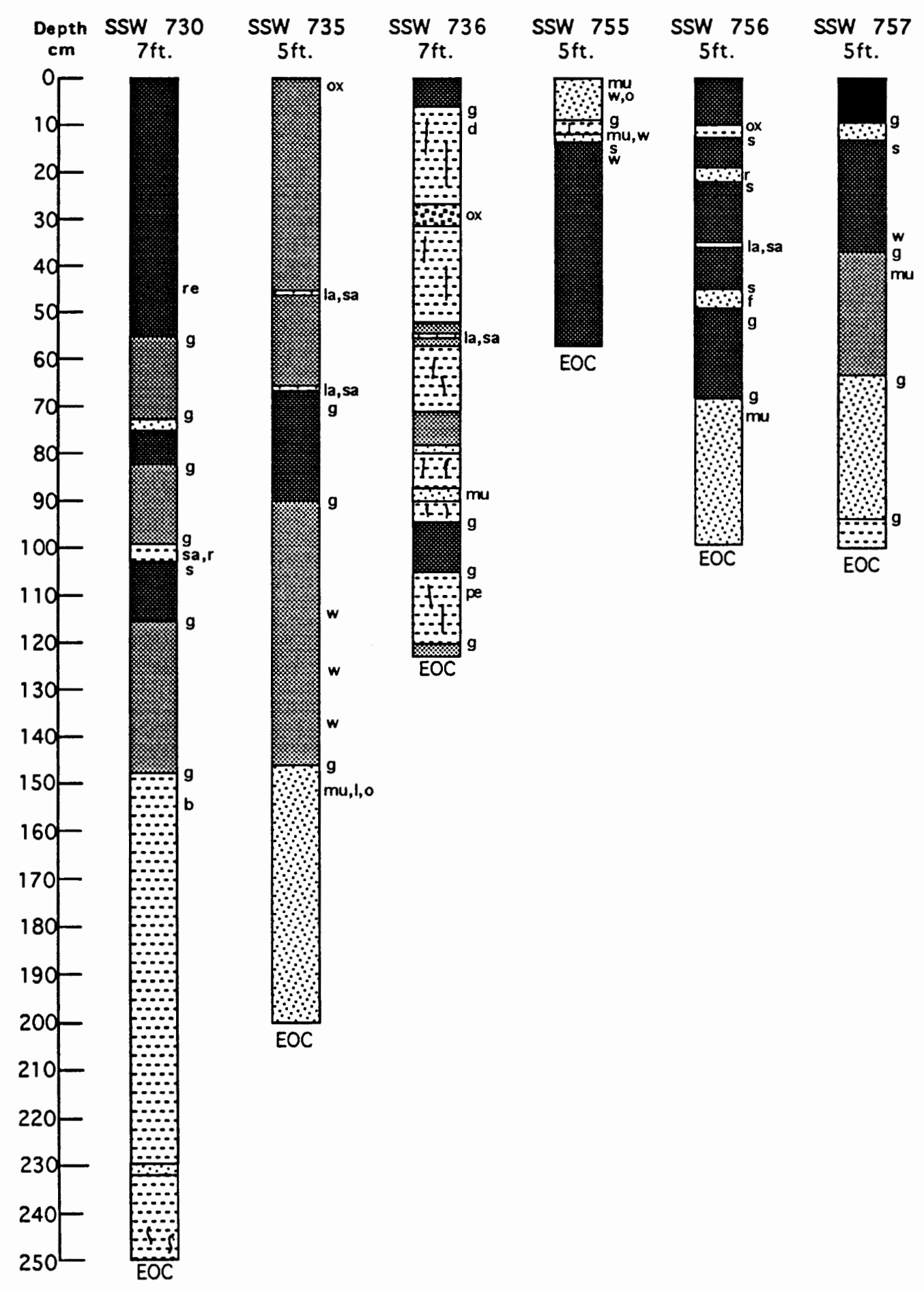



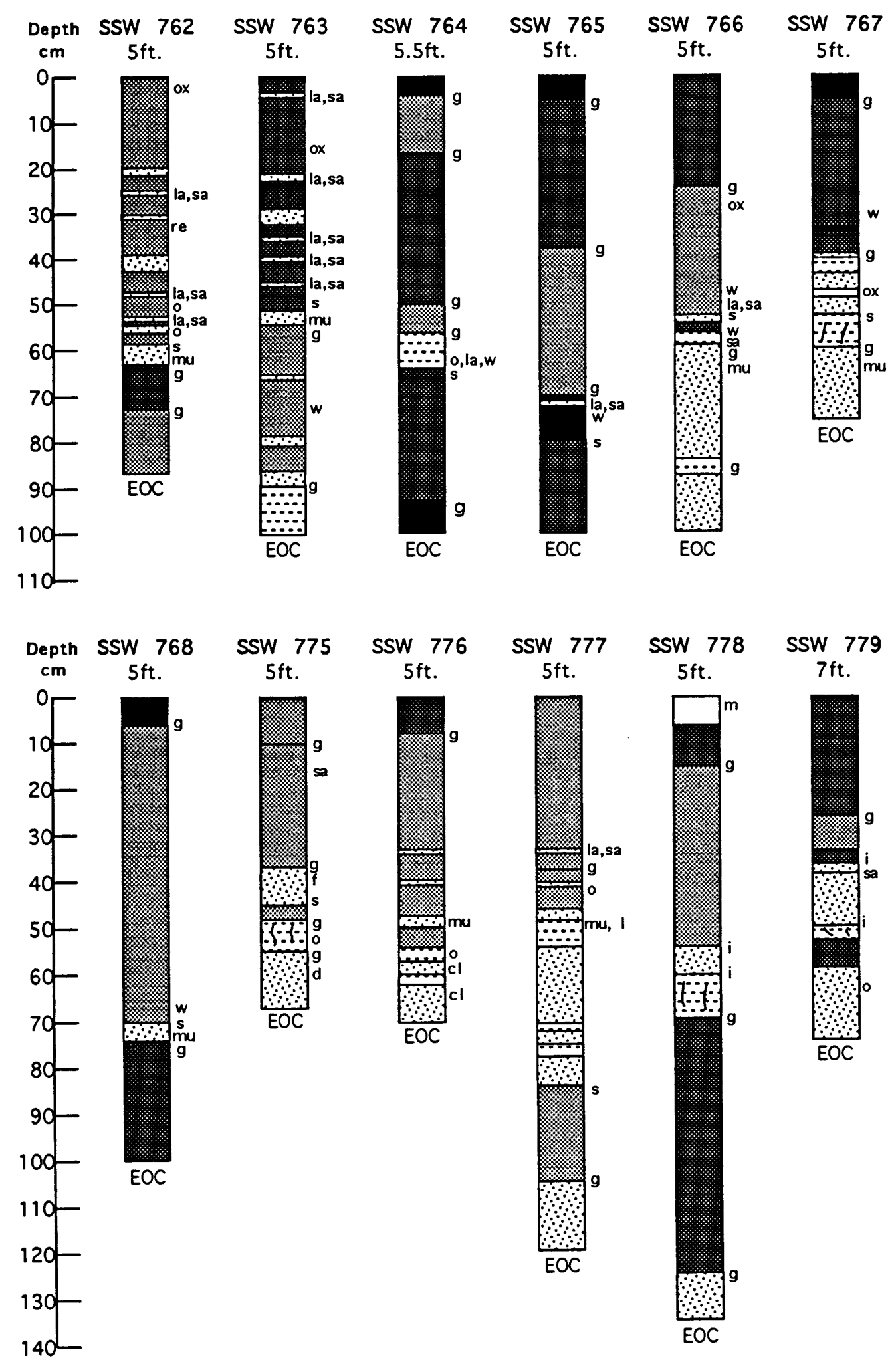

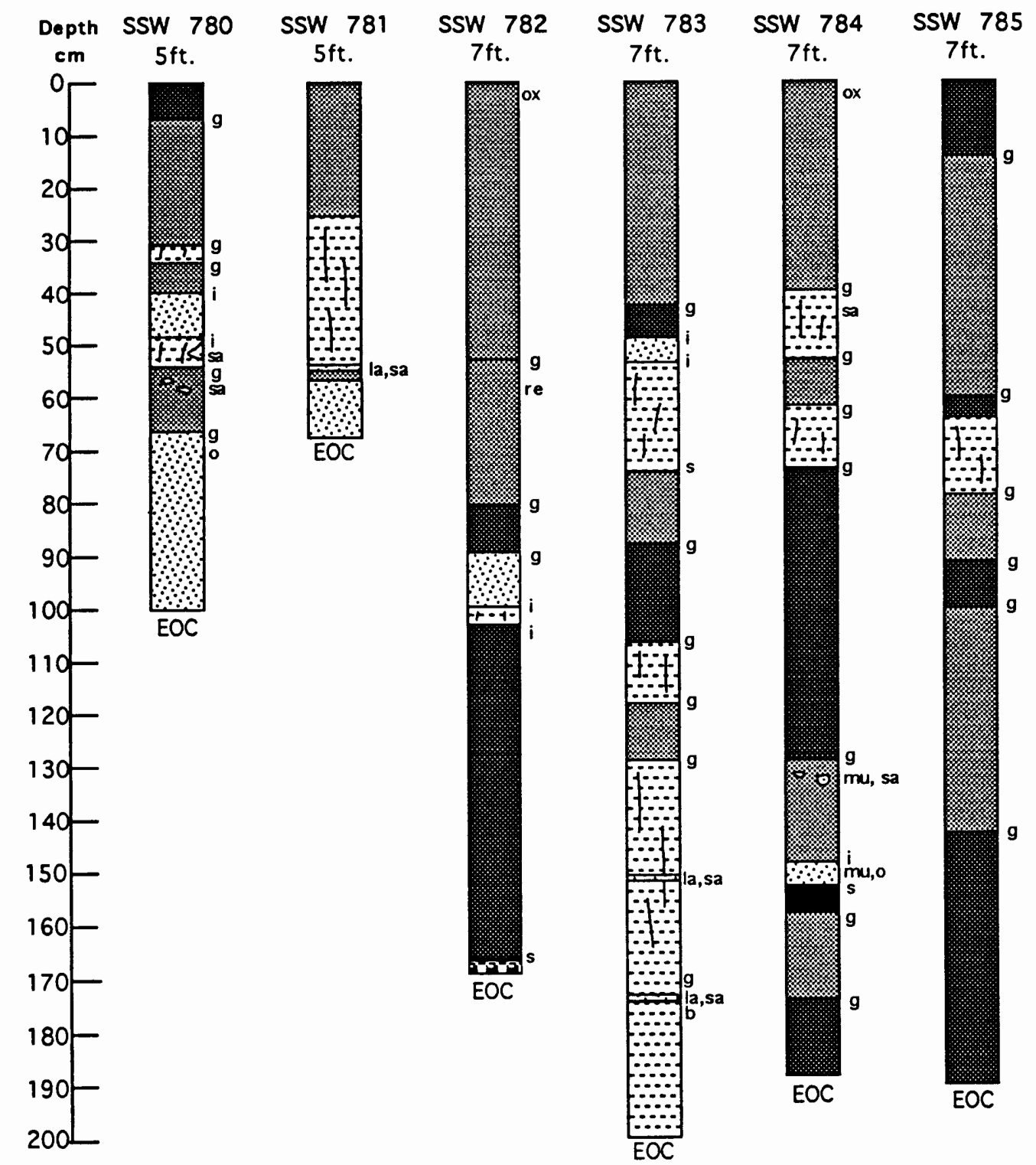


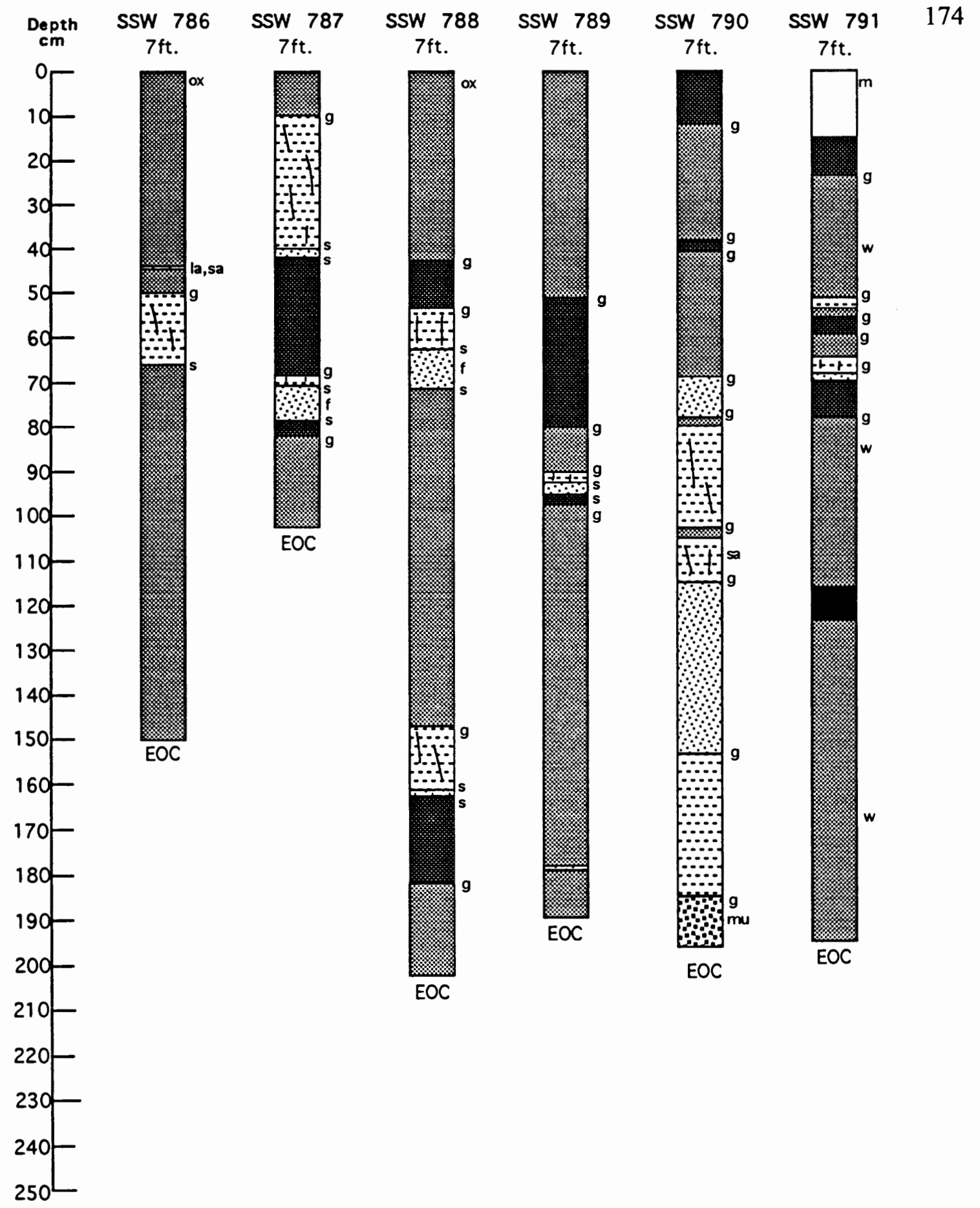




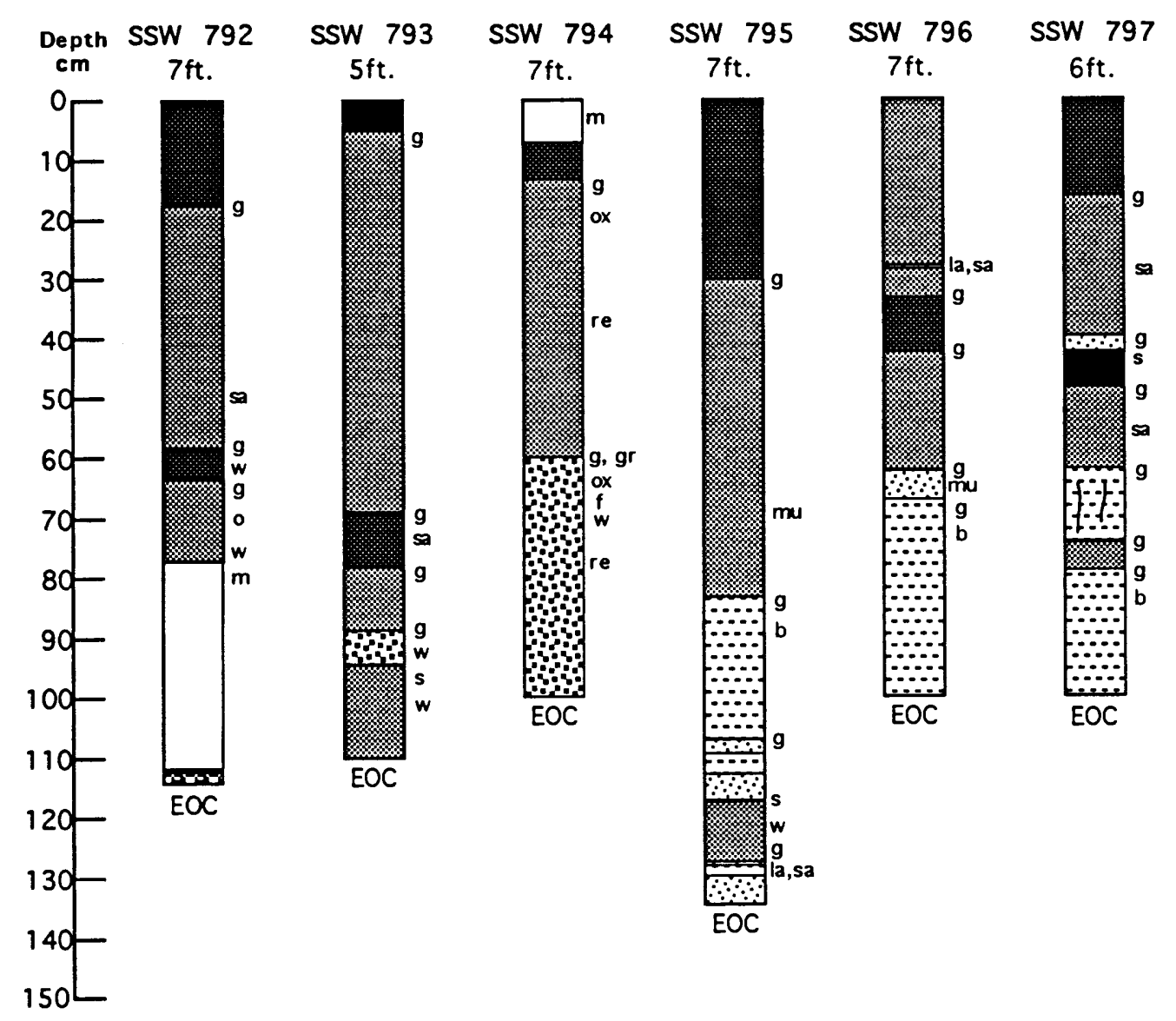




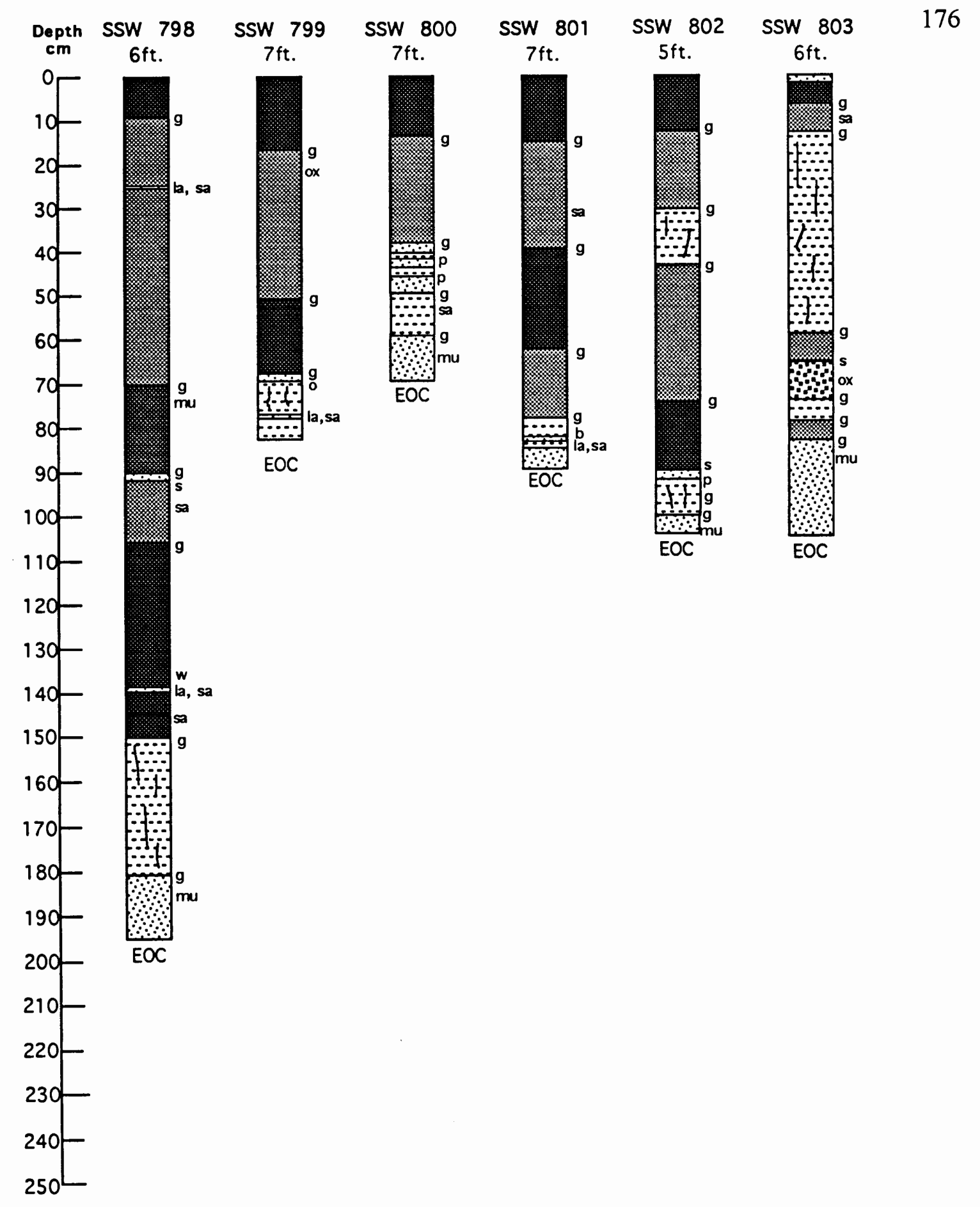




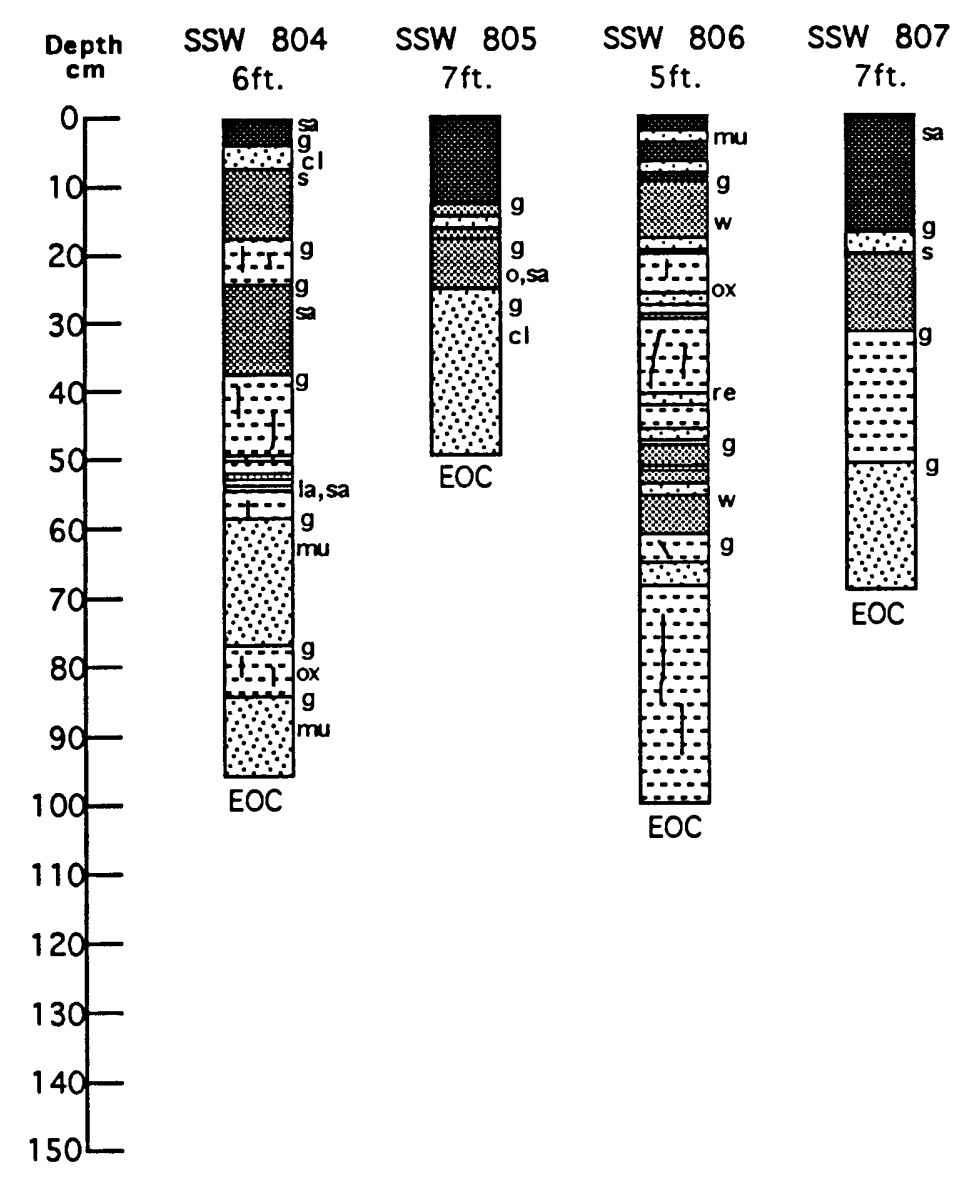

SSW $808 \quad$ SSW $809 \quad 177$ $5 \mathrm{ft} . \quad 5 \mathrm{ft}$.
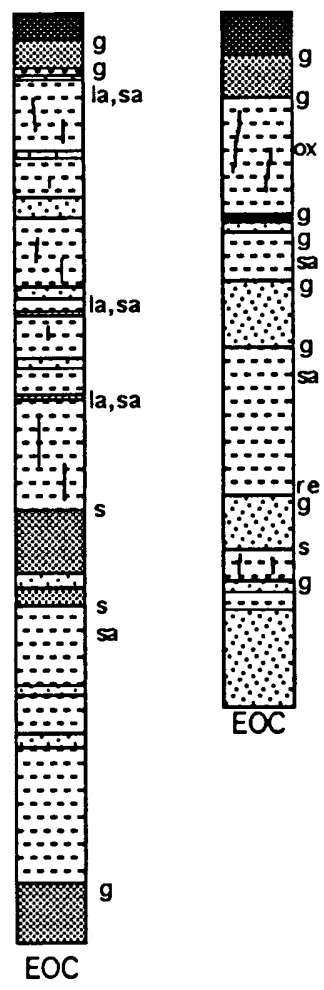


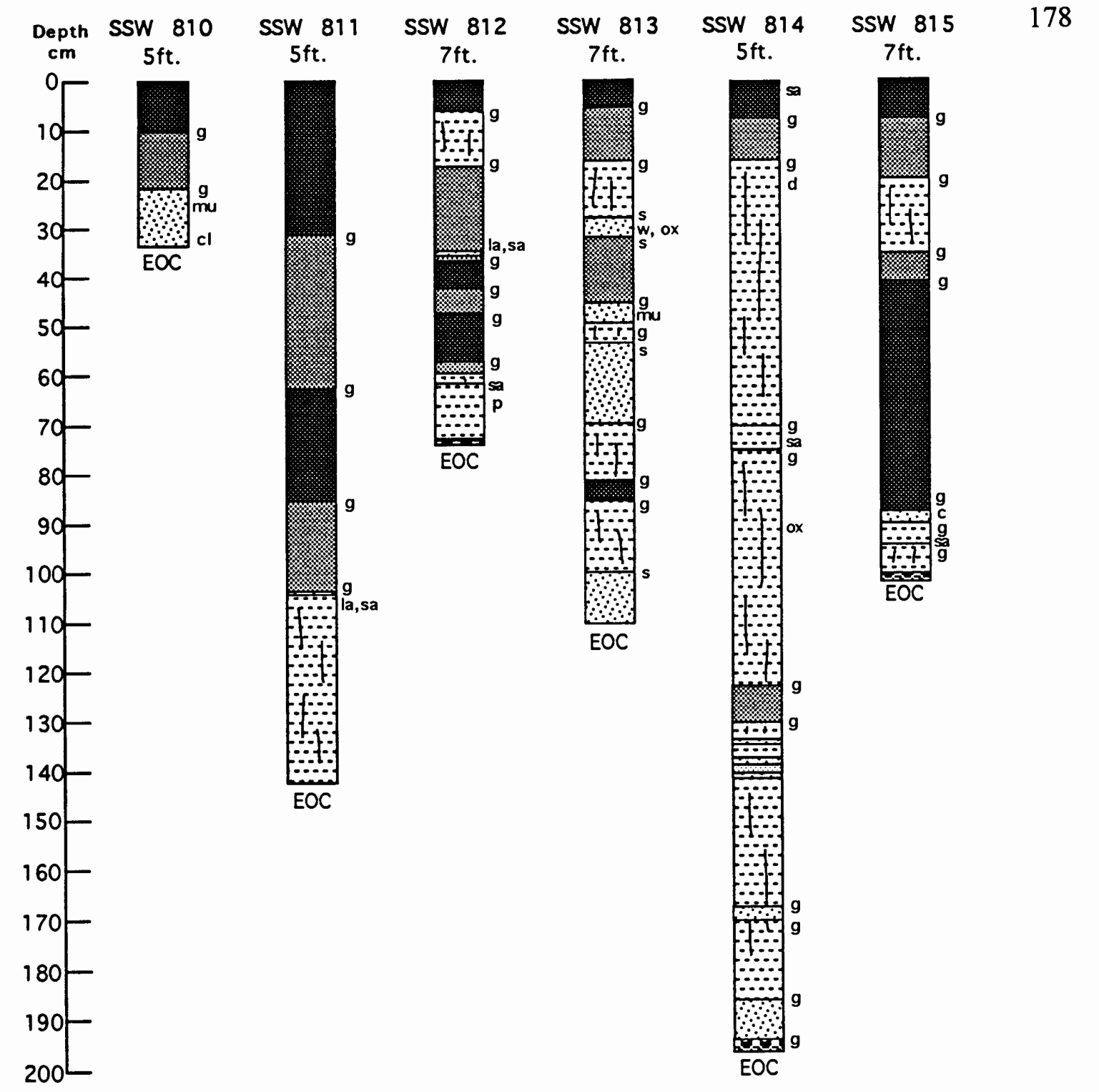




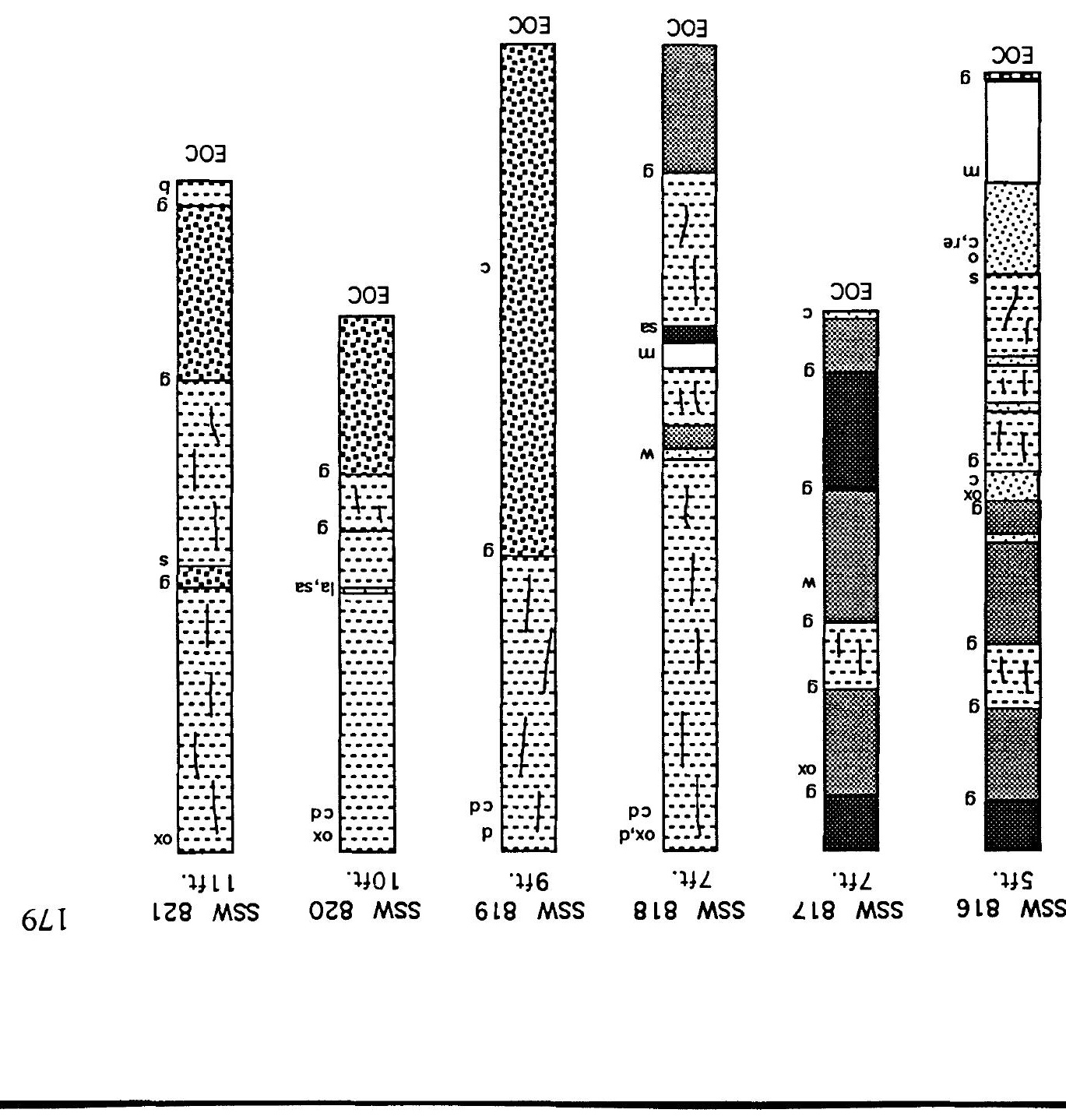




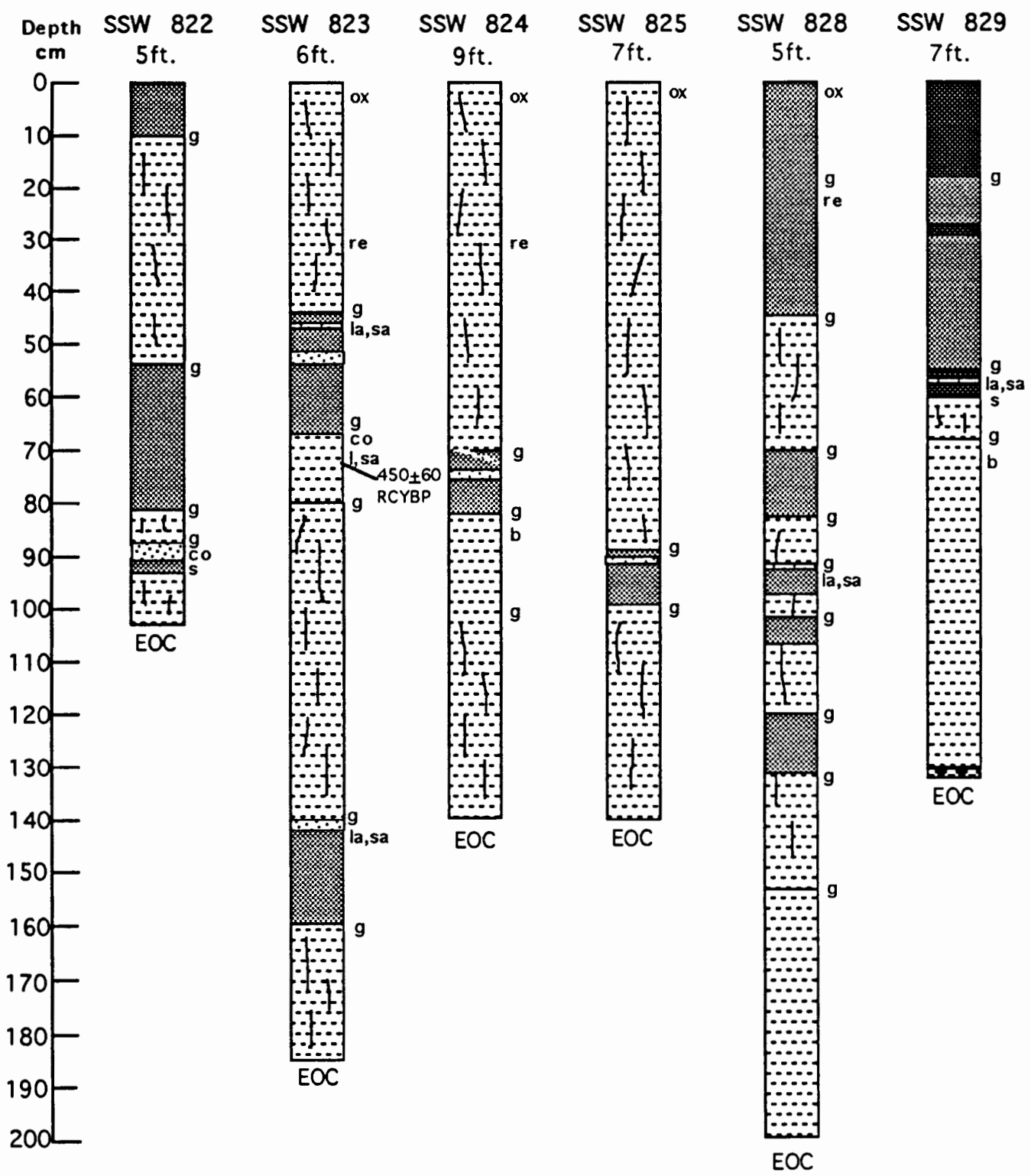




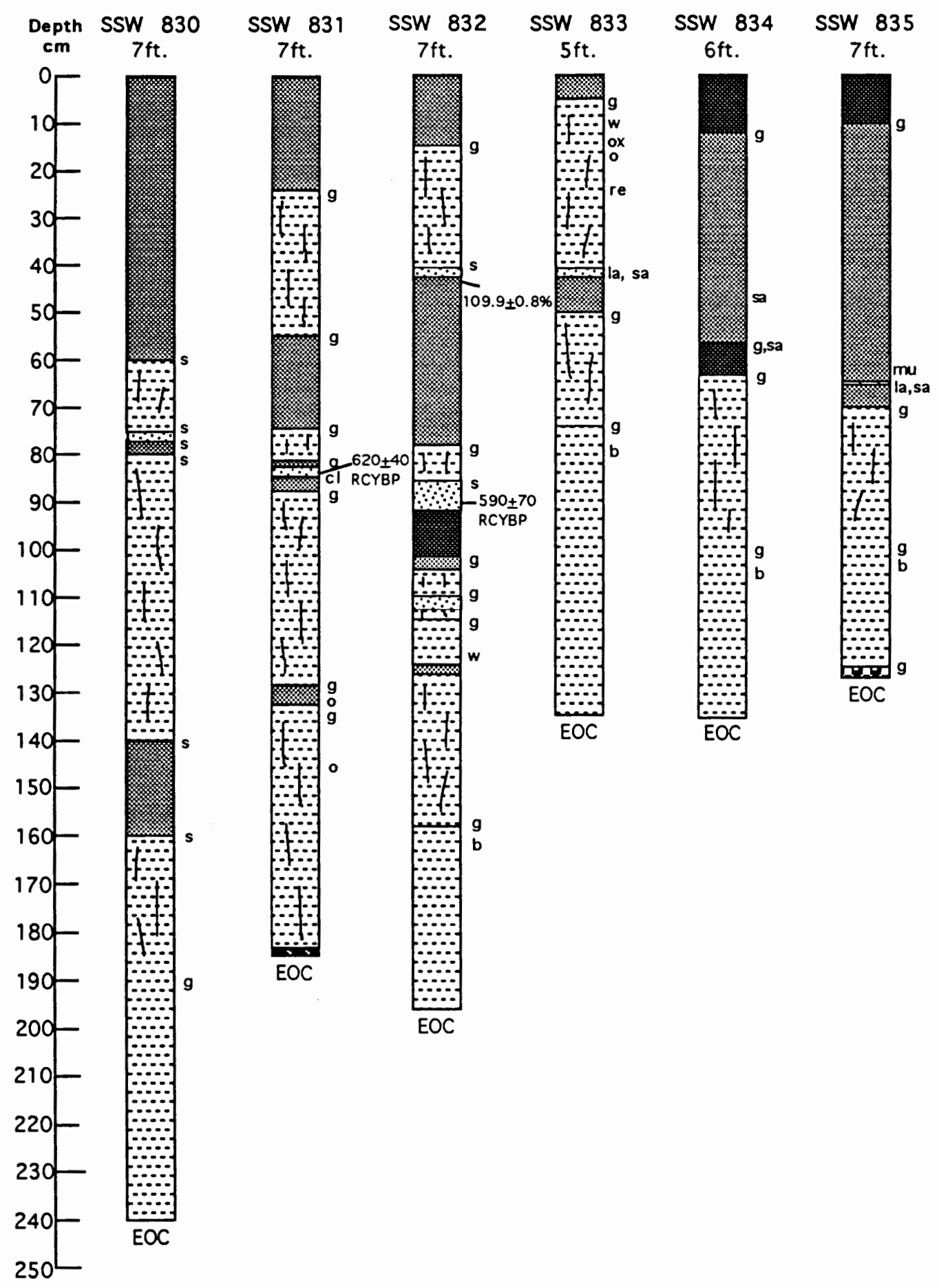




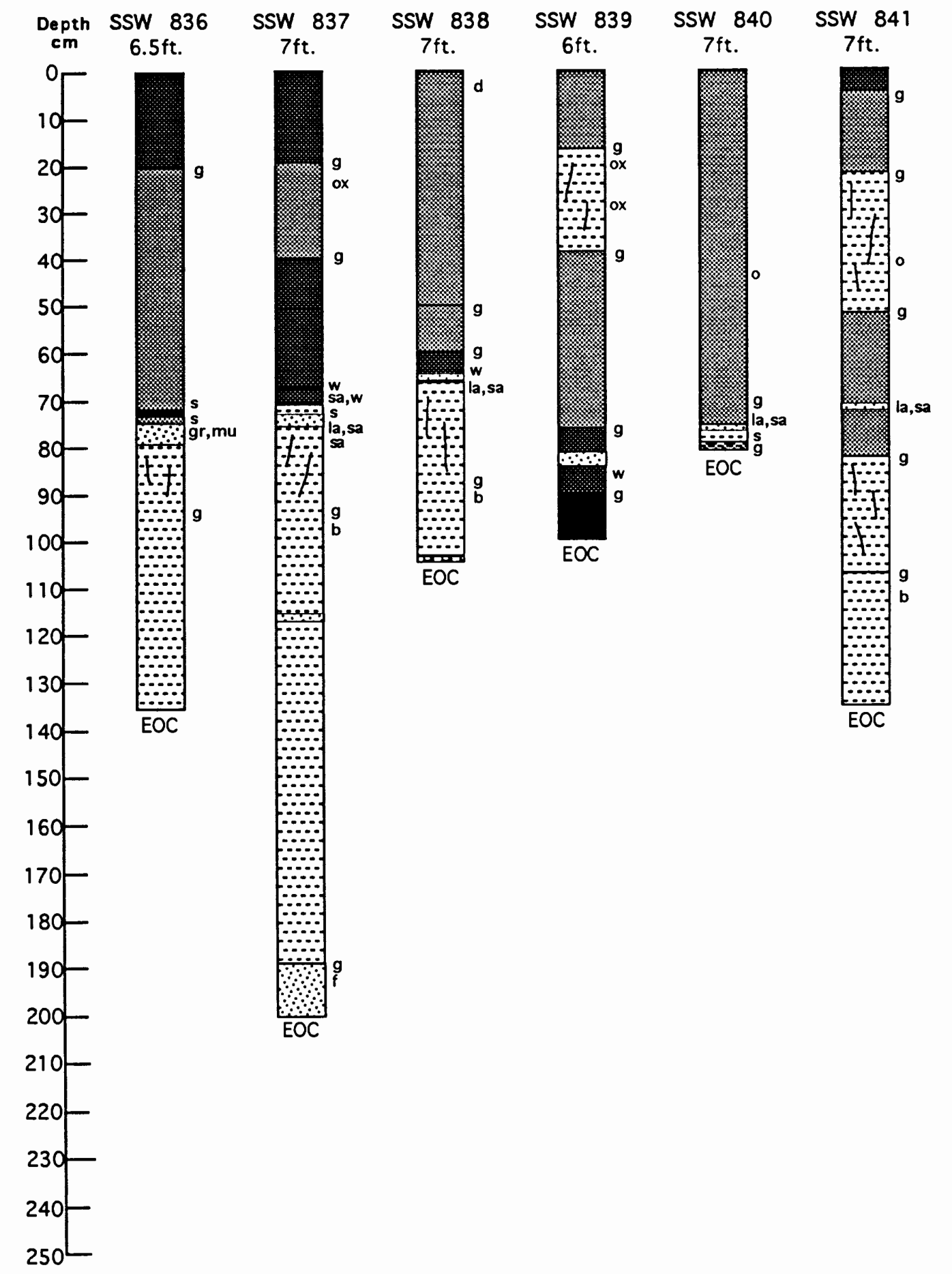




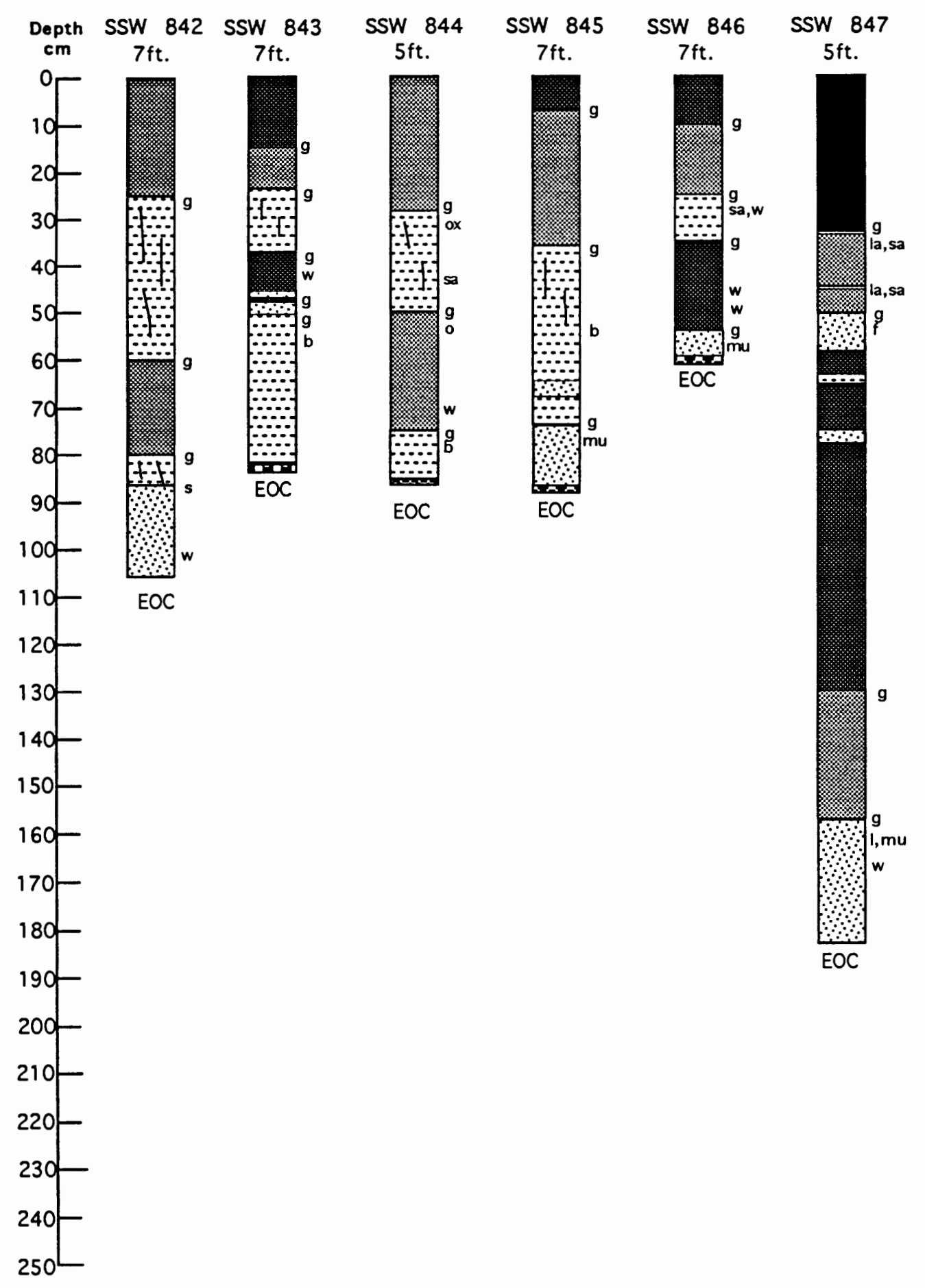




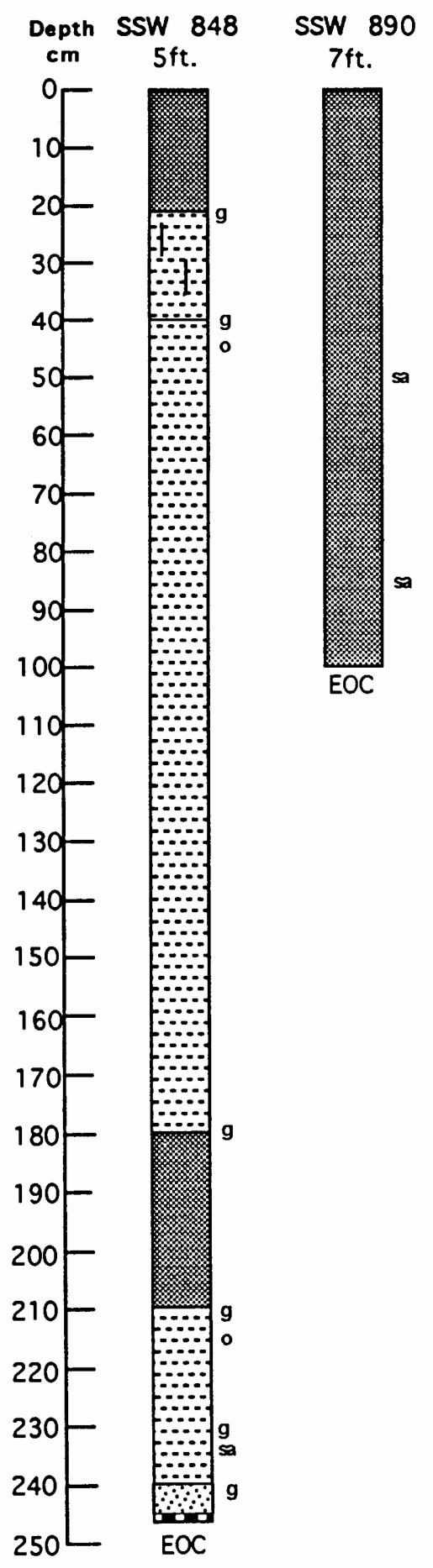




\section{APPENDIX D}

LIST OF RADIOCARBON DATED SAMPLES

REFERENCED TO BETA LAB NUMBERS 


\begin{tabular}{|c|c|c|c|}
\hline CORE NUMBER & $\begin{array}{l}\text { DEPTH OF } \\
\text { SAMPLE }\end{array}$ & $\begin{array}{c}{ }^{14} \text { C AGE YEARS } \\
\text { B.P. } \pm 1 \sigma\end{array}$ & $\begin{array}{l}\text { BETA LAB } \\
\text { NUMBERS }\end{array}$ \\
\hline SSS 879 & $55-56 \mathrm{~cm}$ & $910 \pm 70$ RCYBP & BETA-96834 \\
\hline SSS 879 & $54 \mathrm{~cm}$ & $480 \pm 90$ RCYBP & BETA-099234 \\
\hline SSW 716 & $54 \mathrm{~cm}$ & $\begin{array}{l}101.6 \pm 0.9 \% \\
\text { MODERN }\end{array}$ & BETA-96836 \\
\hline SSW 716 & $81 \mathrm{~cm}$ & $360 \pm 70$ RCYBP & BETA-96837 \\
\hline SSW 729 & $84 \mathrm{~cm}$ & $\begin{array}{c}190 \pm 50 \text { RCYBP } \\
\text { (AMS) }\end{array}$ & BETA-099233 \\
\hline SSW 823 & $74 \mathrm{~cm}$ & $450 \pm 60$ RCYBP & BETA-96835 \\
\hline SSW 831 & $83 \mathrm{~cm}$ & $\begin{array}{c}620 \pm 40 \text { RCYBP } \\
\text { (AMS) }\end{array}$ & BETA-099232 \\
\hline SSW 832 & $43 \mathrm{~cm}$ & $\begin{array}{l}109.9 \pm 0.8 \% \\
\text { MODERN }\end{array}$ & BETA-96839 \\
\hline SSW 832 & $90 \mathrm{~cm}$ & $590 \pm 70$ RCYBP & BETA-96840 \\
\hline SSN 884 & $71-80 \mathrm{~cm}$ & $109.0 \pm 0.9 \%$ RCYBP & BETA-96838 \\
\hline Neawanna 2* & $\begin{array}{c}1.02 \mathrm{~m} \\
0.8 \mathrm{~m} \\
0.39 \mathrm{~m} \\
-0.08 \mathrm{~m} \\
-1.18 \mathrm{~m}\end{array}$ & $\begin{array}{c}480 \pm 60 \text { RCYBP } \\
800 \pm 60 \text { RCYBP } \\
1100 \pm 70 \text { RCYBP } \\
1370 \pm 70 \text { RCYBP }\end{array}$ & $\begin{array}{l}\text { BETA-42112 } \\
\text { BETA-42113 } \\
\text { BETA-42088 } \\
\text { BETA-44595 } \\
\text { BETA-42114 }\end{array}$ \\
\hline Neawanna 5* & $\begin{array}{l}114 \mathrm{~cm} \\
126 \mathrm{~cm}\end{array}$ & $\begin{array}{c}680 \pm 80 \text { RCYBP } \\
2200 \pm 90 \text { RCYBP }\end{array}$ & $\begin{array}{l}\text { BETA-43127 } \\
\text { BETA-42115 }\end{array}$ \\
\hline Neawanna CB4* & $136 \mathrm{~cm}$ & $410 \pm 50$ RCYBP & BETA-43485 \\
\hline Stanley Lake 3* & $\begin{array}{l}44 \mathrm{~cm} \\
84 \mathrm{~cm}\end{array}$ & $\begin{array}{c}780 \pm 90 \text { RCYBP } \\
2370 \pm 60 \text { RCYBP }\end{array}$ & $\begin{array}{l}\text { BETA-57850 } \\
\text { BETA-57852 }\end{array}$ \\
\hline Necanicum 3* & $90-100 \mathrm{~cm}$ & $170 \pm 90$ RCYBP & BETA-58074 \\
\hline
\end{tabular}

* Radiocarbon dates from Darienzo and others, 1991, depth of samples noted according to mean tidal level. 


\section{APPENDIX E}

FIELD DATA GRID CORE LOCATIONS

NEACOXIE CREEK (SSX)

AND

NEAWANNA CREEK (SSW) 


\begin{tabular}{|c|c|c|c|c|c|c|}
\hline SSX Site & Date & State & Plane & UTM & $\overline{\text { UTM }}$ & Surf. \\
\hline Number & 1996 & Northing & Easting & Northing & Easting & Elev. \\
\hline I & 17-Jul & 876019 & 1132835 & 5096368 & 429236 & 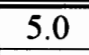 \\
\hline II & 17-Jul & 875934 & 1132827 & 5096342 & 429234 & 5.0 \\
\hline III & 17-Jul & 875853 & 1132815 & 5096317 & 429231 & 5.0 \\
\hline IV & 17-Jul & 875771 & 1132805 & 5096292 & 429229 & 6.0 \\
\hline $\mathrm{V}$ & 17-Jul & 875689 & 1132794 & 5096267 & 429226 & 6.0 \\
\hline VI & 17-Jul & 875606 & 1132704 & 5096241 & 429200 & 5.0 \\
\hline VII & 17-Jul & 875524 & 1132776 & 5096216 & 429222 & 6.0 \\
\hline VIII & 17-Jul & 875447 & 1132764 & 5096193 & 429219 & 6.0 \\
\hline IX & 17-Jul & 875366 & 1132753 & 5096168 & 429217 & 6.0 \\
\hline $\mathrm{X}$ & 17-Jul & 875205 & 1132744 & 5096119 & 429216 & 6.0 \\
\hline $\mathrm{XI}$ & 17-Jul & 875218 & 1132738 & 123 & 429214 & 5.5 \\
\hline XII & 17-Jul & 876029 & 1132762 & 5096370 & 429213 & 7.0 \\
\hline XIII & 17-Jul & 875957 & 1132749 & 5096348 & 429210 & 5.0 \\
\hline XIV & 18-Jul & 875873 & 1132733 & 5096322 & 429206 & 5.0 \\
\hline $\mathrm{XV}$ & 18-Jul & 875790 & 1132720 & 509 & 429203 & 0.0 \\
\hline $\mathrm{XVI}$ & 17-Jul & 875968 & 1132670 & 5096351 & 429186 & 7.0 \\
\hline XVII & 17-Jul & 875889 & 1132655 & 5096327 & 429182 & 6.0 \\
\hline XVIII & 17-Jul & 875806 & 1132639 & 5096301 & 429178 & 6.0 \\
\hline $\mathrm{XIX}$ & 17-Jul & 875725 & 1132622 & 5096276 & 429174 & 6.0 \\
\hline $\mathrm{XX}$ & 18-Jul & 875710 & 1132704 & 5096272 & 429199 & 5.0 \\
\hline XXI & 18-Jul & 875627 & 1132690 & 5096247 & 429195 & 7.0 \\
\hline XXII & 18-Jul & 875547 & 1132675 & 5096223 & 429191 & 7.0 \\
\hline XXIII & 18-Jul & 875466 & 1132659 & 5096198 & 429187 & 7.0 \\
\hline XXIV & 18-Jul & 875836 & 1132645 & 5096310 & 429180 & 7.0 \\
\hline XXV & 18-Jul & 875309 & 1132631 & 5096150 & 429180 & 7.0 \\
\hline XXVI & 18-Jul & 875239 & 1132640 & 5096128 & 429184 & 8.0 \\
\hline XXVII & 18-Jul & 875116 & 1132726 & 5096092 & 429211 & 5.0 \\
\hline XXVIII & 18-Jul & 875058 & 1132719 & 5096074 & 429209 & 5.0 \\
\hline \multicolumn{7}{|c|}{ State Plane: North American Datum 1927, northern Oregon, in U.S. survey feet. } \\
\hline \multicolumn{7}{|c|}{ UTM: Universal Transverse Mercator coordinates in North American Datum 1927, } \\
\hline \multicolumn{7}{|c|}{ zone 10 , in meters. } \\
\hline \multicolumn{7}{|c|}{ Surface Elevation: CH2MHILL 1973 Datum to the nearest extrapolated one } \\
\hline foot $(+1 \mathrm{ft})$. & & & & & & \\
\hline$\theta$ & & & & & & \\
\hline
\end{tabular}




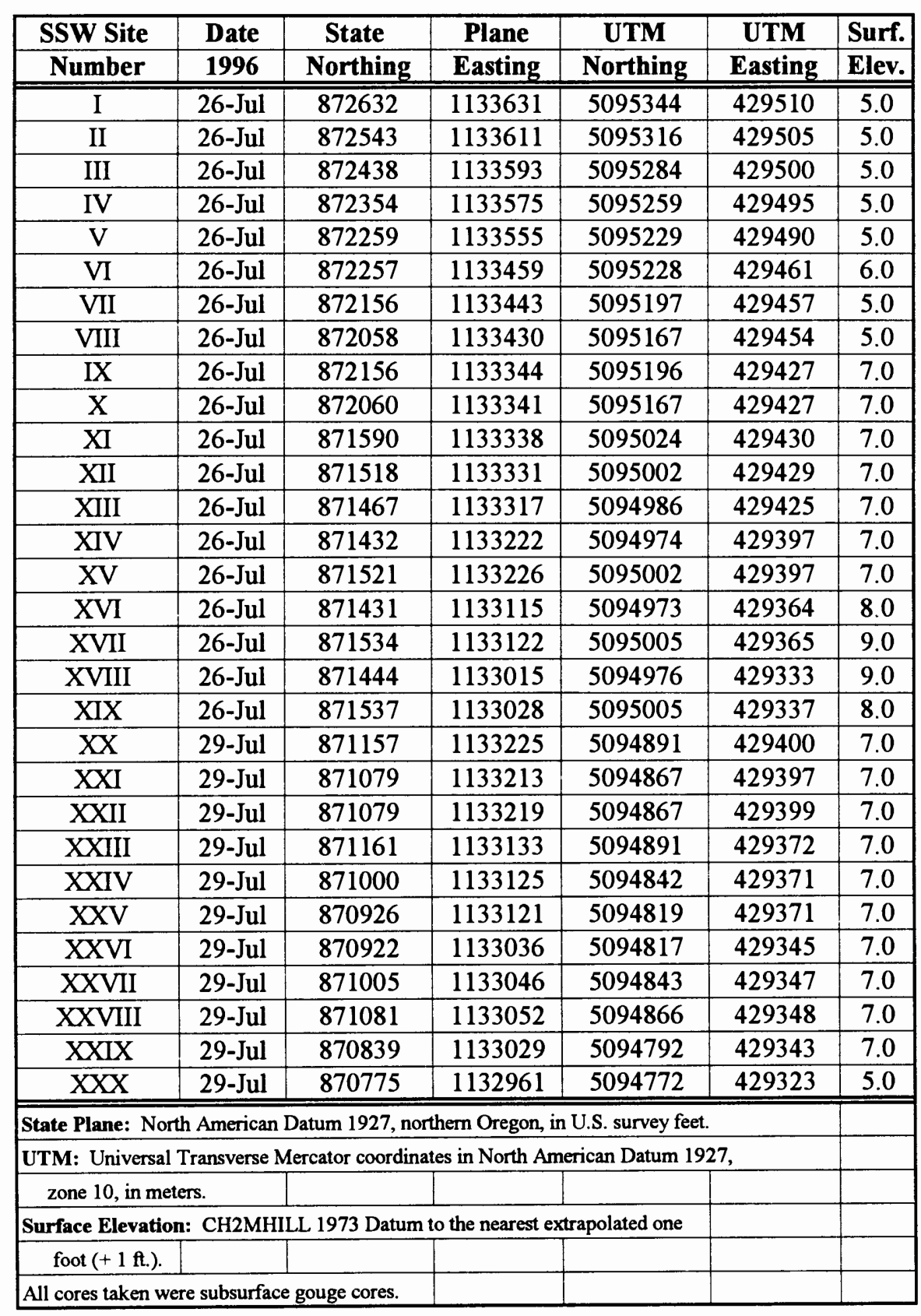




\section{APPENDIX F}

\section{FIELD DATA GRID CORE LOGS}

NEACOXIE CREEK (SSX)

AND

NEAWANNA CREEK (SSW) 
Core Log Legend

Neacoxie Creek Grid (SSX)

I-XII 193

XIII-XXIV

194

XXV-XXVIII

195

Neawanna Creek Grid (SSW)

I-XVIII

196

XIX-XXX 


\section{Core Log Legend}

$\begin{array}{llll}\text { peat } & \text { sand cobble } & \\ \text { muddy peat } & & \end{array}$

$\begin{aligned} \text { SSN } & \text { Necanicum River } \\ \text { SSS } & \text { Stanley Lake } \\ \text { SSW } & \text { Neawanna Creek } \\ \text { SSX } & \text { Neacoxie Creek } \\ \text { SSXa } & \text { Drainage to east of Neacoxie Creek }\end{aligned}$

$\begin{array}{rlrlrl}\text { b } & \text { barren } & \text { f } & \text { fining upward } & \text { p } & \text { pebble } \\ \text { c } & \text { coarse } & \text { g } & \text { gradual } & \text { pe } & \text { peaty } \\ \text { cd } & \text { core drag } & \text { i } & \text { intruded/irregular } & \text { r } & \text { rooted } \\ \text { ch } & \text { charcoal } & \text { I } & \text { layer }(>5 \mathrm{~mm}) & \text { R C } & \text { Radiocarbon sample } \\ \text { cl clean } & \text { Ia } & \text { lamination }(<5 \mathrm{~mm}) & \text { re } & \text { reduced } \\ \text { co } & \text { cobble } & \mathrm{m} & \text { missing section } & \text { s } & \text { sharp } \\ \text { cont. } & \text { continued } & \text { mu } & \text { muddy } & \text { sa } & \text { sandy } \\ \text { d dense } & \text { o } & \text { organic debris } & \text { w } & \text { wood fragments } \\ \text { EOC } & \text { end of core } & \text { ox } & \text { oxidized } & & \end{array}$



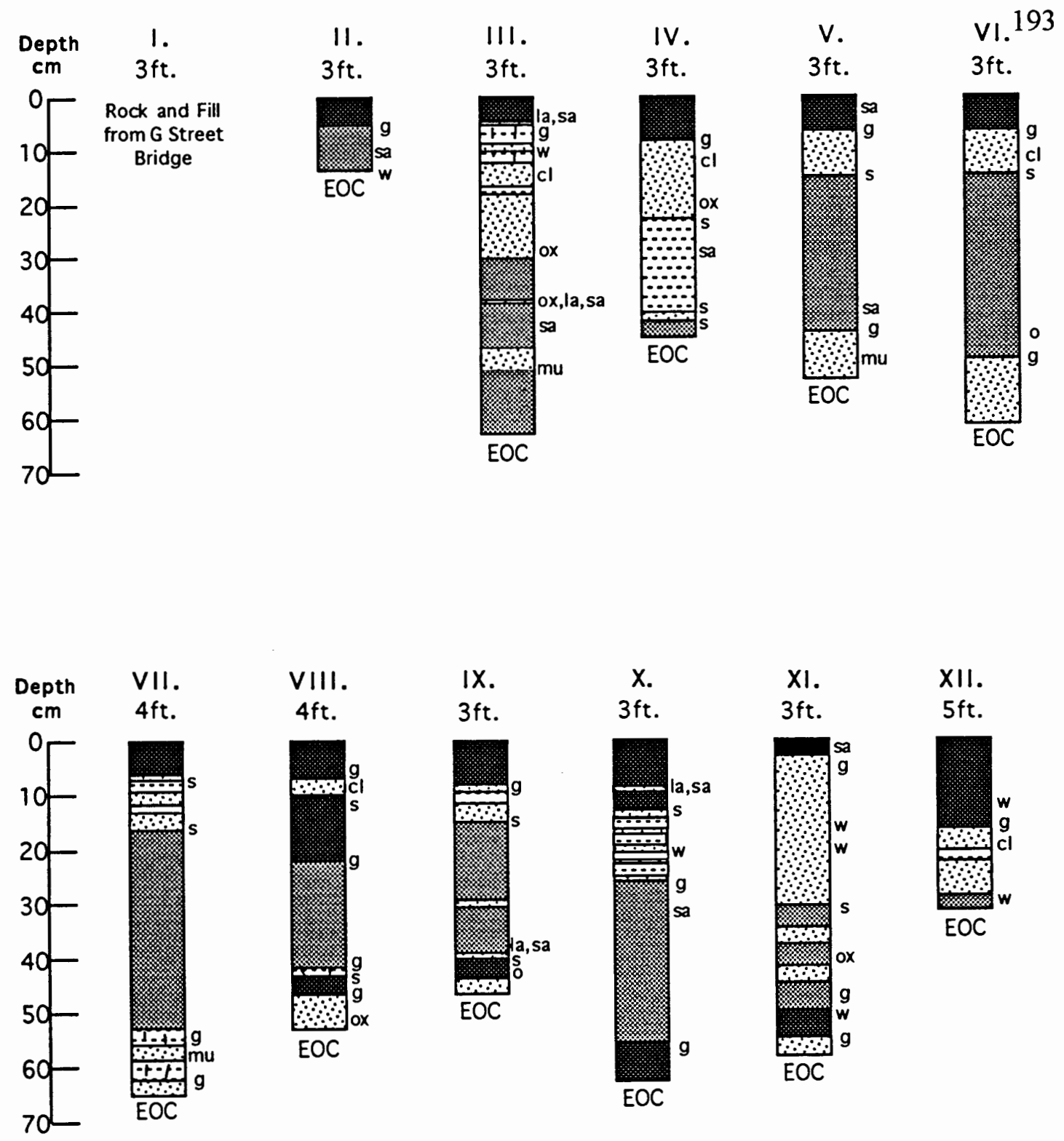

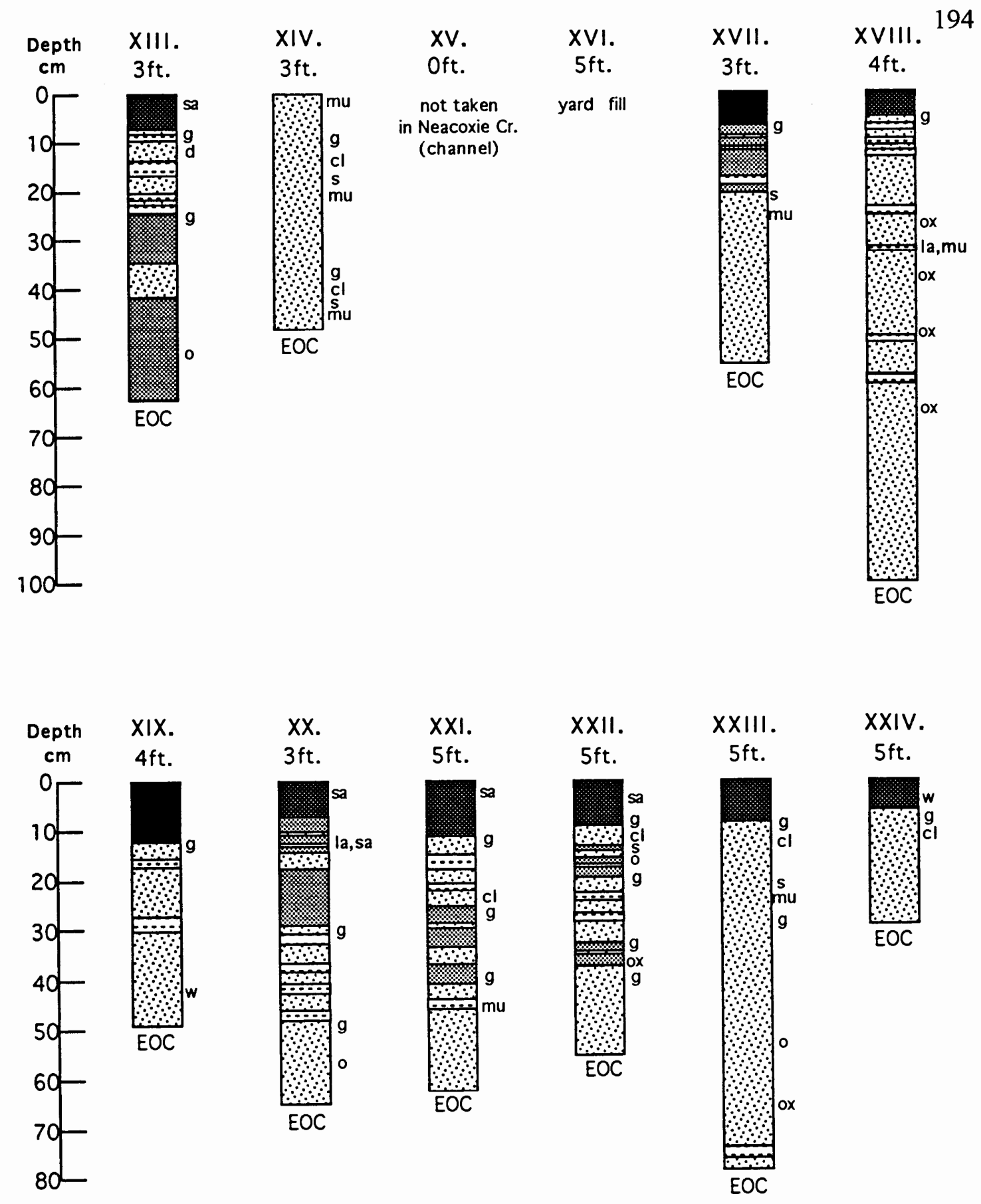


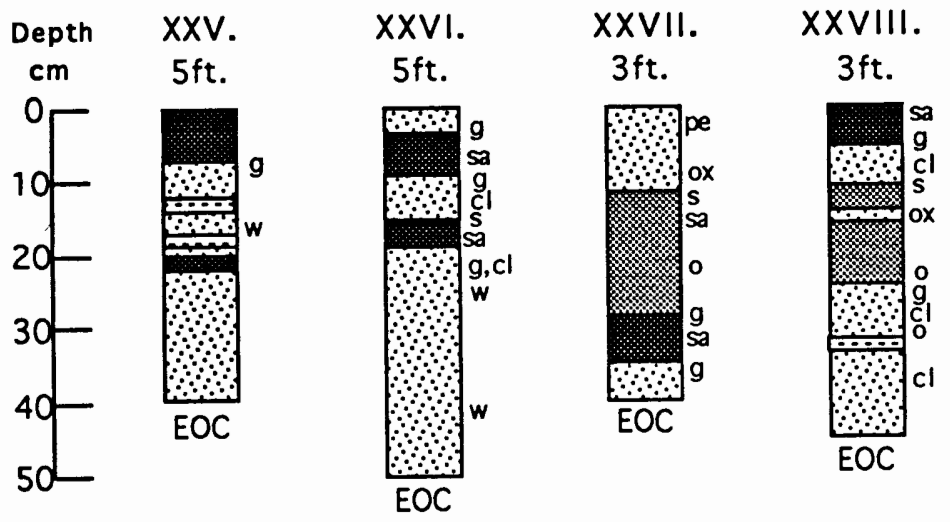



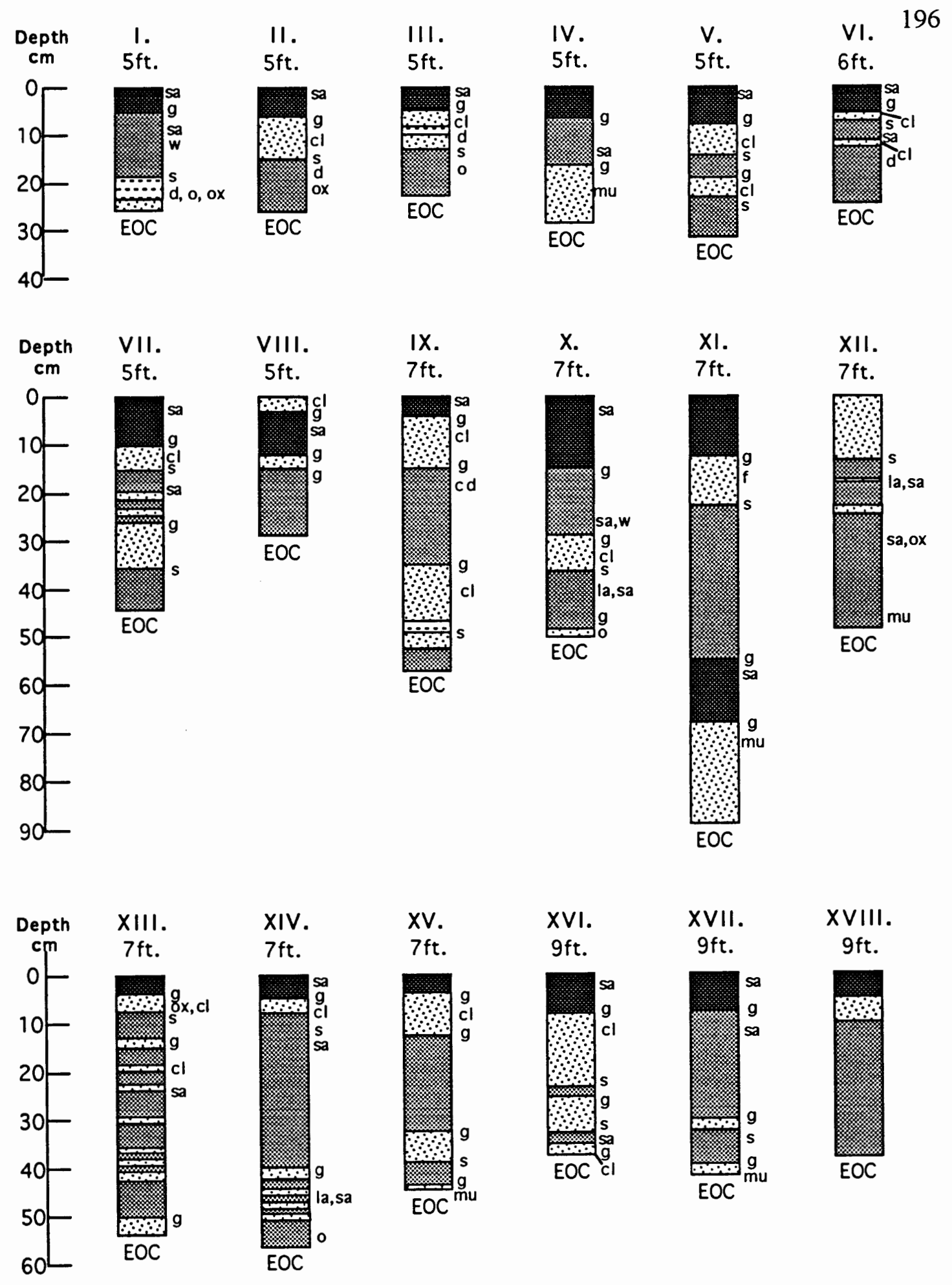

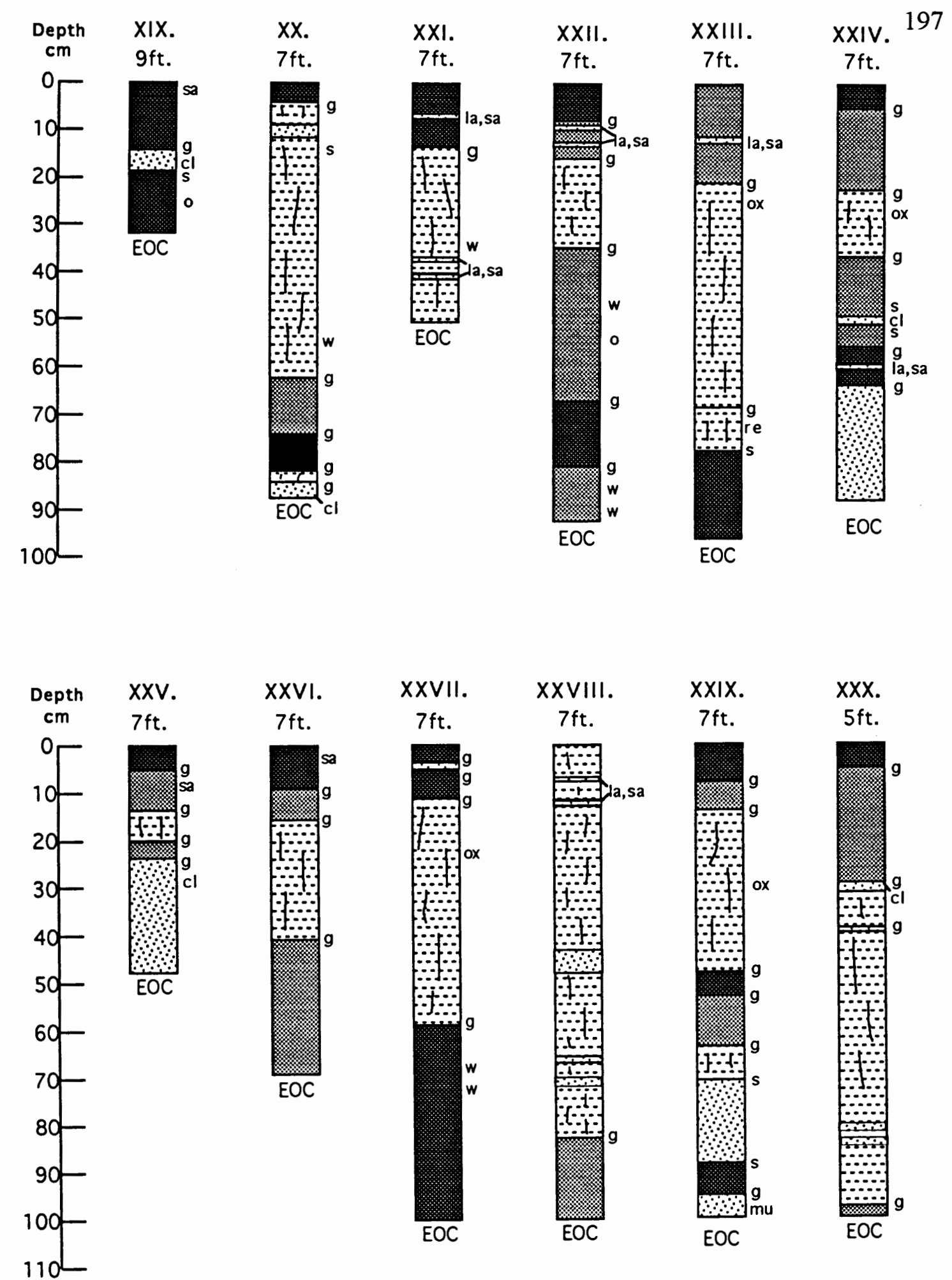


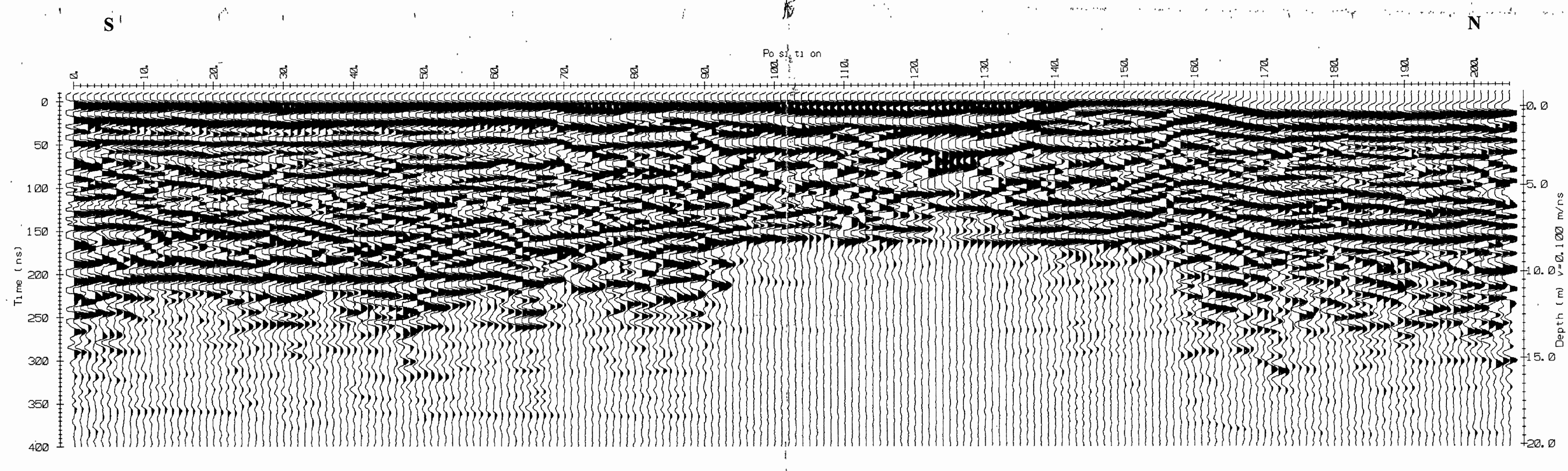




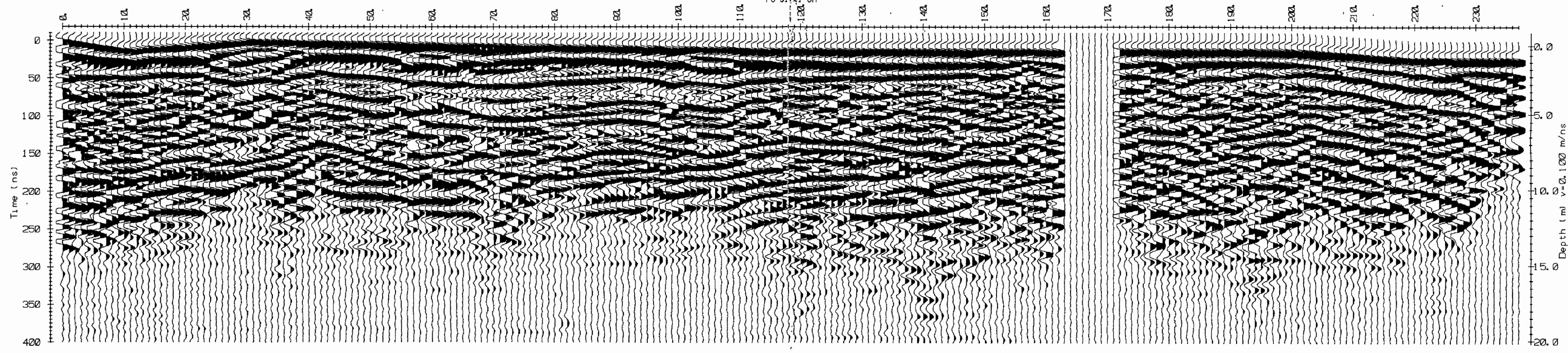


W

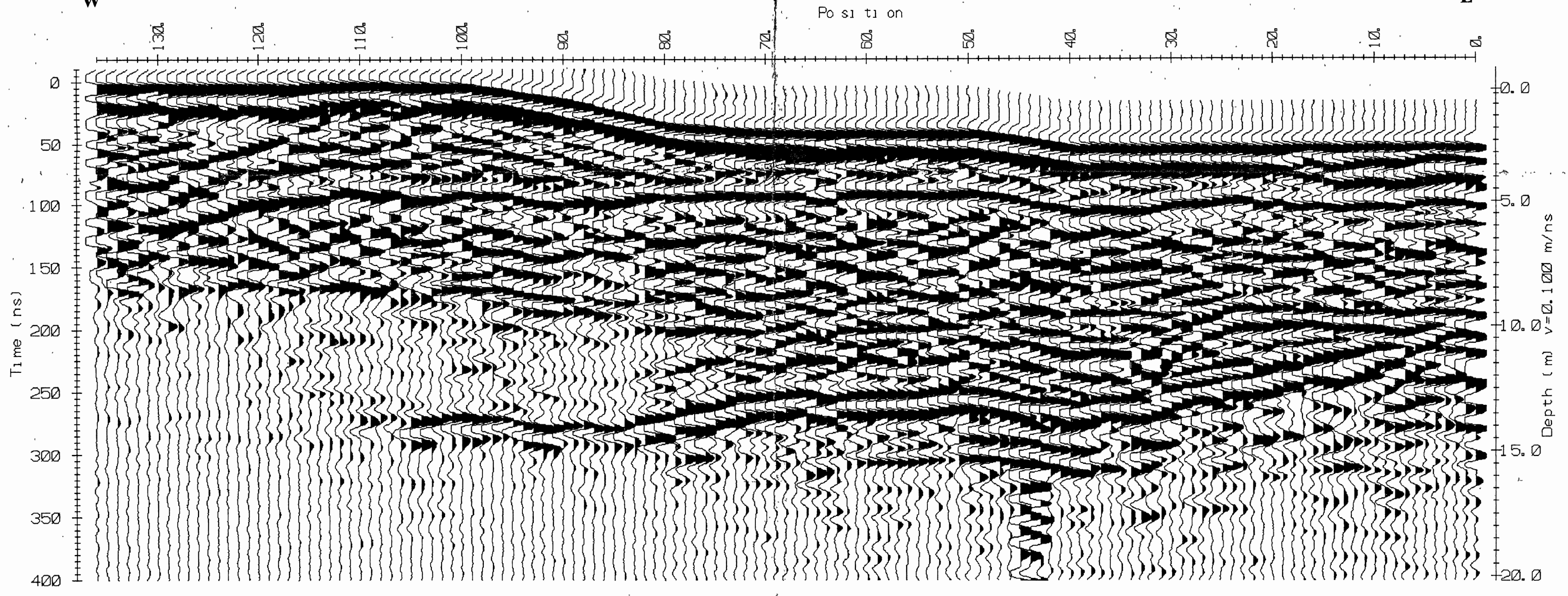




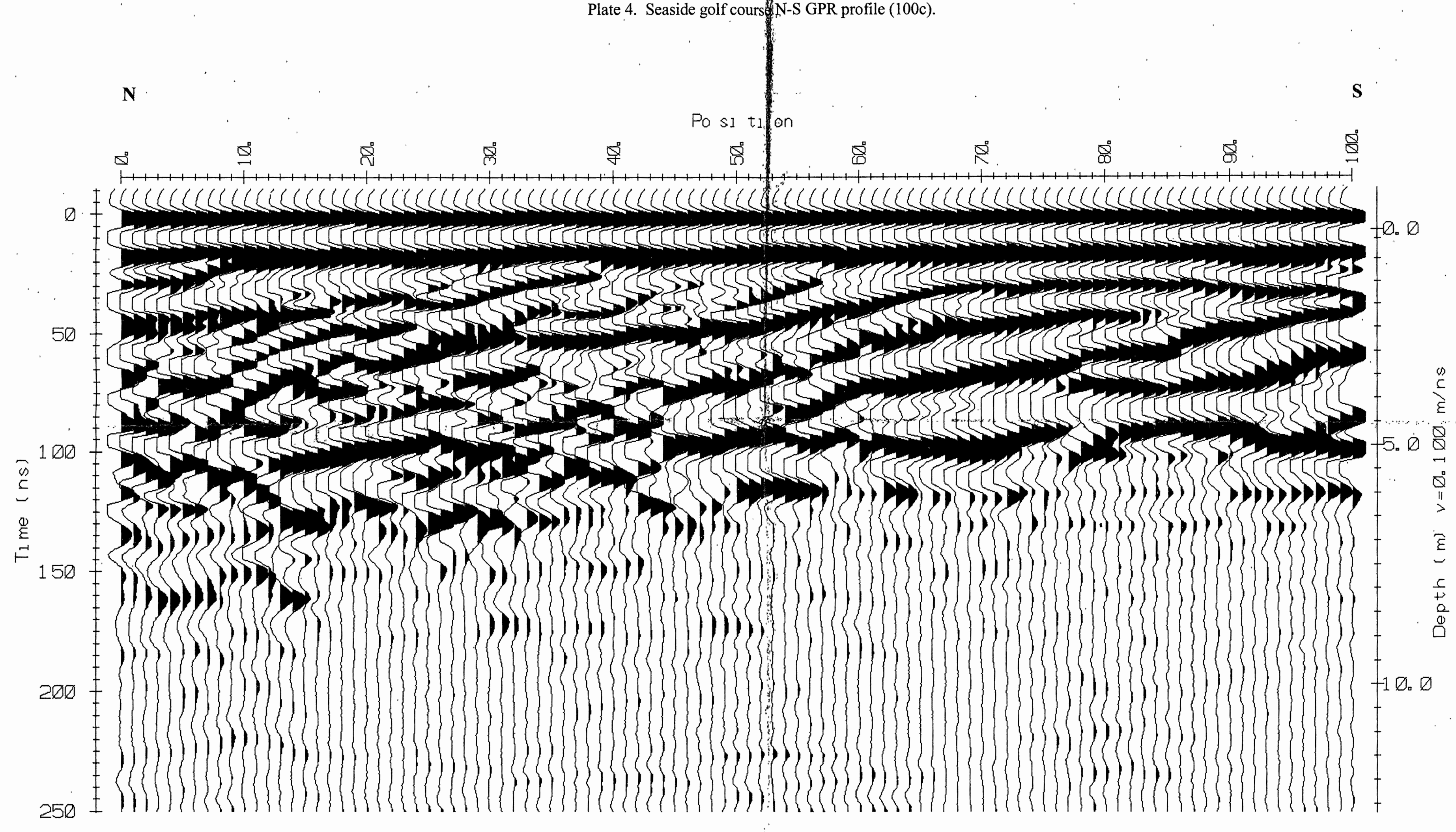




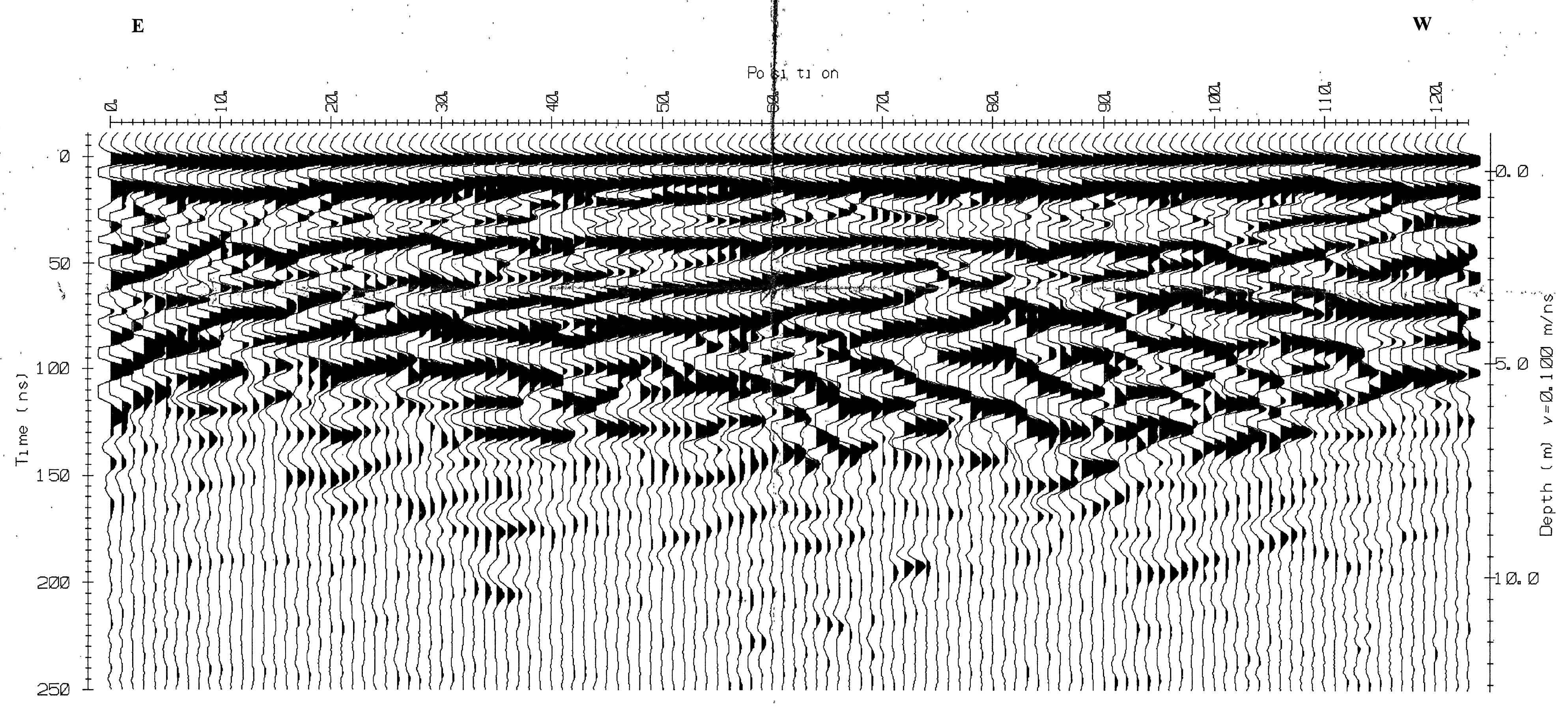



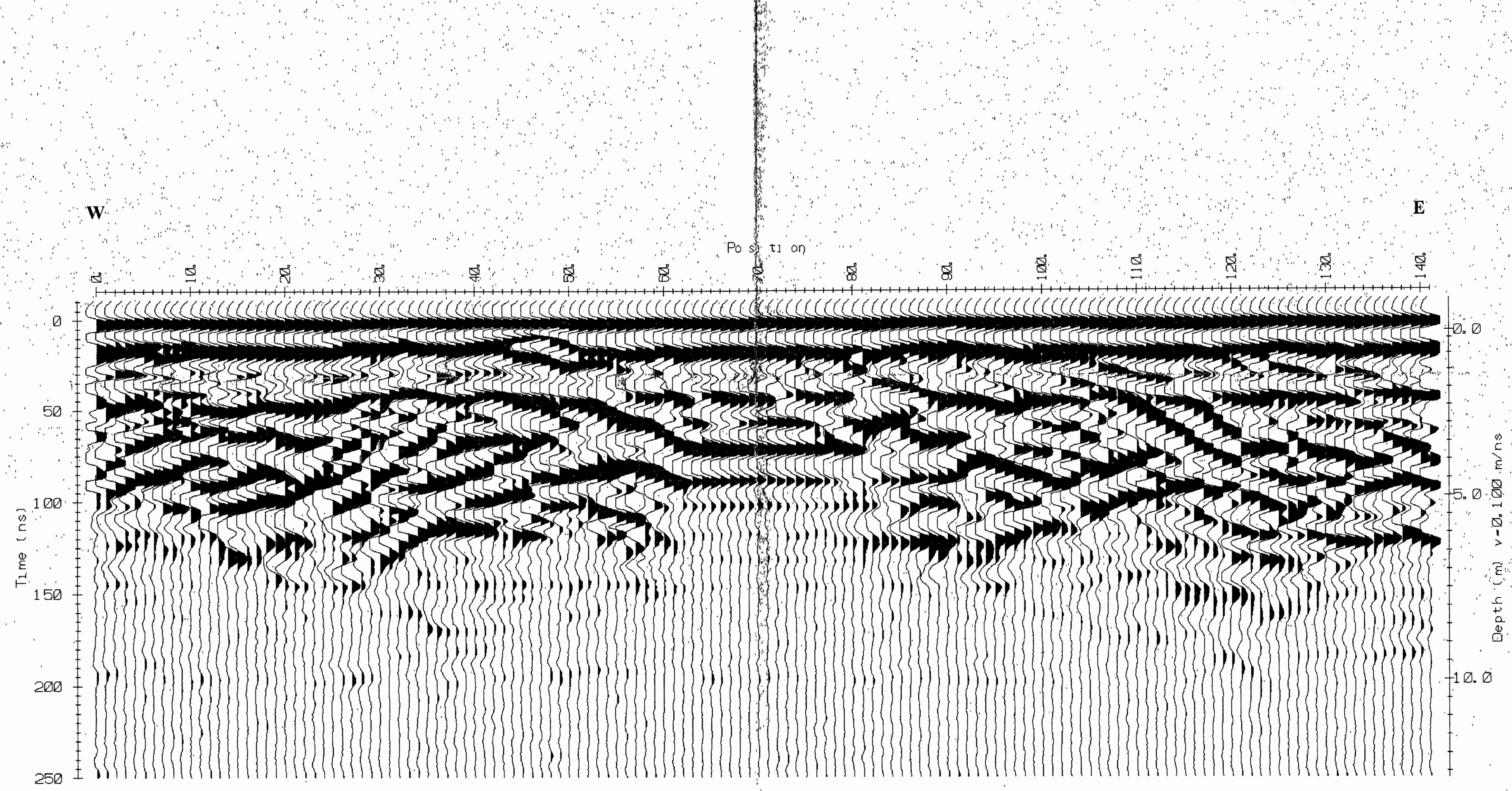